\author{
Universidade de São Paulo \\ Instituto de Física - Instituto de Química \\ Instituto de Biociências - Faculdade de Educação
}

\title{
Do Visível ao Indivisível: uma proposta de Física de Partículas Elementares para o Ensino Médio
}

\author{
Maxwell Roger da Purificação Siqueira
}

Orientador: Prof. Dr. Maurício Pietrocola

Dissertação de mestrado apresentada ao Instituto de Física, ao Instituto de Química, ao Instituto de Biociências e a Faculdade de Educação da Universidade de São Paulo, para a obtenção do título de Mestre em Ensino de Ciências.

Comissão Examinadora:

Prof. Dr. Maurício Pietrocola - USP

Prof. Dr. Frederico Firmo de Souza Cruz - UFSC

Profa. Dra. Jesuína Lopez de Almeida Pacca - USP

São Paulo

2006 


\section{FICHA CATALOGRÁFICA Preparada pelo Serviço de Biblioteca e Informação do Instituto de Física da Universidade de São Paulo}

\begin{tabular}{|l|}
\hline Siqueira, Maxwell Roger da Purificação \\
Do visível ao indivisível: uma proposta de física de partículas \\
elementares para o ensino de física. \\
São Paulo, 2006. \\
Dissertação (Mestrado) - Universidade de São Paulo. \\
Instituto de Física e Faculdade de Educação. \\
Orientador: Prof. Dr. Maurício Pietrocola Pinto de Oliveira \\
Área de Concentração: Ensino de ciências. \\
Unitermos: 1. Ensino ; 2. Física ; 3. Física moderna; 4. Partículas \\
elementares. \\
USP/IF/SBI-081/2006
\end{tabular}




\section{SUMÁRIO}

Agradecimentos

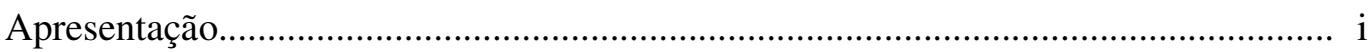

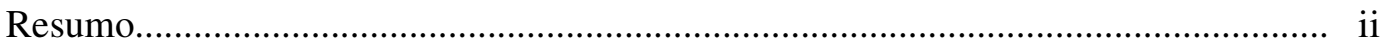

Capítulo 1 - 0 ensino de Física e a necessidade de atualização curricular............. 1

1.1 - Introdução.............................................................................................. 1

1.2 - Por que inserir Física Moderna e Contemporânea no ensino médio?......... 3

1.3 - Porque Física de Partículas? .................................................................. 12

Capítulo 2 - Uma área de conhecimento contemporâneo: Física de Partículas

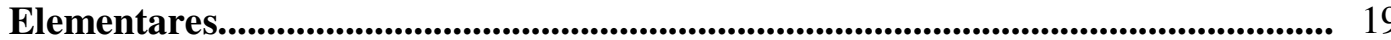

2.1 - Introdução.......................................................................................... 19

2.2 - A idéia Grega do elemento primordial................................................. 21

2.3 - As investigações do século X ao XIX...................................................... 23

2.4 - As primeiras evidências das partículas subatômicas: a descoberta dos raios-X e da radioatividade..................................................................... 26

2.5 - Dividindo o indivisível: a descoberta do elétron e os modelos atômicos... 28

2.5.1 - A descoberta do Nêutron e suas implicações...................................... 31

2.6 - Uma grande mudança na ciência: a descoberta do posítron....................... 33

2.7 - As novas interações...................................................................... 37

2.7.1 - Explicando a estabilidade do núcleo............................................. 38

2.7.2 - O problema do decaimento beta.................................................. 40

2.7.3 - A descoberta de novas partículas.................................................... 42

2.8 - Enfim, o Modelo Padrão...................................................................... 44

Capítulo 3 - O Curso................................................................................................ 47

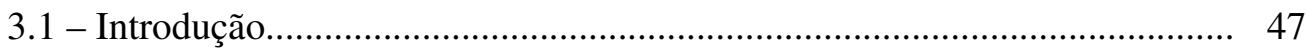

3.2 - O recorte dos saberes................................................................ 47

3.3 - Algumas propostas........................................................................ 49

3.4 - A seqüência didática..................................................................... 54

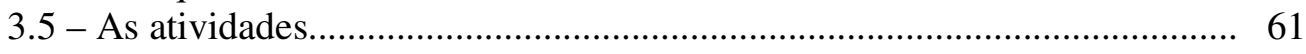

Capítulo 4 - A Transposição Didática.................................................................... 63

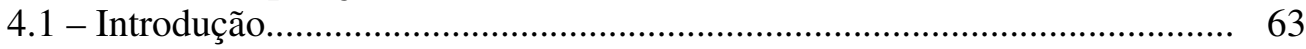

4.2 - As Adaptações do saber para a escola..................................................... 63

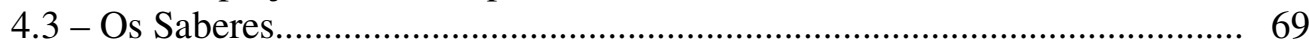

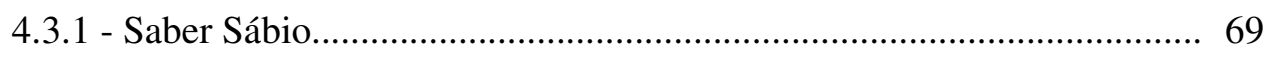

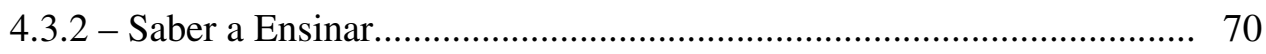

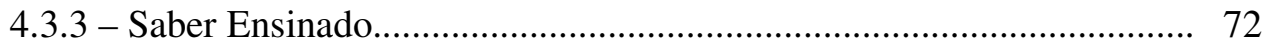

4.3.4 - Como o saber sobrevive............................................................. 75

4.3.5 - Práticas sociais de referência......................................................... 76

4.3.6 - As regras da Transposição Didática................................................. 78

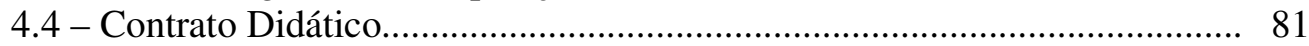

4.4.1 - Introdução .................................................................................. 81

4.4.2 - Instrumento de análise da ação pedagógica: O Contrato Didático..... 82

4.5 - A Física de Partículas com o olhar da Transposição Didática.................... 85

4.6 - Livro didático: A Física de Partículas como Saber a Ensinar..................... 89 
Capítulo 5 - A metodologia de pesquisa.............................................................. 96

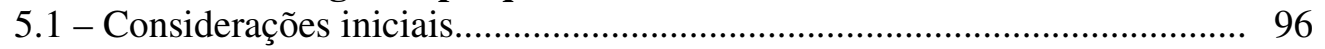

5.2 - A metodologia de pesquisa.................................................................. 97

5.2.1 - A tomada de dados.................................................................. 100

A gravação das aulas: observações................................................. 101

O questionário................................................................................... 101

Analise dos documentos........................................................... 102

5.2.2 - O local de aplicação......................................................................... 102

5.2 .3 - As características da turma............................................................ 103

5.3 - A figura do professor........................................................................ 104

Capítulo 6 - A análise de dados: .............................................................................. 107

6.1 - Introdução...................................................................................... 107

6.2 - A análise dos marcadores................................................................ 113

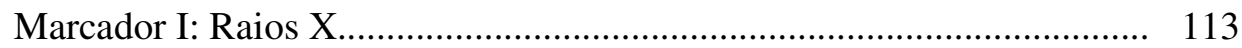

Marcador II - Espelhamento Rutherford............................................ 126

Marcador III - Estrutura das Partículas................................................. 137

6.3 - A análise da estrutura do curso: o questionário....................................... 146

Considerações Finais.................................................................................................. 151

Referências Bibliográficas....................................................................................................... 156

Anexos 


\section{AGRADECIMENTOS}

À minha família, pois sem ela nada disso poderia Ter ocorrido. À minha mãe por nunca deixar de acreditar nos meus sonhos e jamais ter deixado que parasse os estudos mesmo com todas as dificuldades que passamos pela vida, por ter me ensinado ser uma pessoa boa, honesta, responsável e acima de tudo ter respeito pelo ser humano.

Ao meu irmão, Robert que sempre esteve ao meu lado, ajudando e apoiando as minhas decisões, dando força nos momentos difíceis, sendo o amigo e o companheiro de sempre. À minha irmã, Cristiane, que também sempre esteve do meu lado para tudo. Suas duas filhas, Pamela e Mirella, que muitas vezes serviram de motivação a mais para continuar sendo uma pessoa batalhadora, otimista e honesta, na qual elas poderiam se espelhar todos os dias. Ao meu pai, Norberto, que apesar de tudo, sempre me deu força para fazer a grande mudança da minha vida, sair de Minas Gerais (Juiz de Fora) e vir para São Paulo, continuar estudando.

Às pessoas que sempre ajudaram para que esse sonho pudesse ter início, os féis amigos de sempre, Estevam e Guilherme. Sem eles nada disso poderia ter sido feito. Por muitas vezes, serviram de apoio, para continuar a caminhada e nunca desanimar dos objetivos.

Aos amigos que deixei em Juiz de Fora, Marta, Fausto, Fátima, Fernanda que participaram ativamente do início da mudança e sempre com palavras de motivação e otimismo para ajudar a continuar a caminhada e agüentar os difíceis momentos que apareceram pela vida.

Aos amigos feitos em São Paulo, Lúcia Helena, Thaís Forato, Ivã Gurgel, Beatriz Fagundes que sempre estavam bem dispostos a ajudar a qualquer momento com simples conversas informais nos cafés ou com leituras de trabalhos indicando novas referências para melhorar a pesquisa.

Aos companheiros do LaPEF, Valéria, Cristina, João, Wellington, Josias, André, Alex, Rogério, Carla, Luciana, Thaís Coterlinni, Cândida que criaram um ambiente agradável e acolhedor no LaPEF, tornando um espaço onde sempre foi e será bom de 
estar lá. Além das trocas de experiências de trabalhos e indicações de leituras que foram muito úteis.

A Camila, minha namorada, que sempre procurou me apoiar em vários momentos, sempre escutando meus desabafos, todas minhas frustrações, todas as minhas inquietudes. Creio que não tenha consciência de sua importância nesse processo, mas sem ela, talvez parte desse trabalho não tivesse acontecido de maneira objetiva e clara como aconteceu. Isso só foi possível com suas palavras de incentivo.

Ao Maurício que, como orientador, sempre acreditou no meu potencial em desenvolver este trabalho. Sempre foi compreensível com as inquietudes e os problemas com a pesquisa enfrentados durante o período de desenvolvimento desse trabalho. Sendo, muitas vezes, paciente para entender os problemas pessoais e ajudando a superálos com conversas. Sem falar nas enormes contribuições para que me desenvolvesse como pesquisador.

A todas as outras pessoas que passaram pela minha vida e me ajudaram a progredir como pessoa, pesquisador e educador.

A Deus, pois tornou possível tudo isso acontecer, me dando uma família que amo muito, amigos que serão para sempre e força, para nunca desistir daquilo que busco.

Agradeço a CAPES e FAPESP pelo apoio financeiro

Obrigado a todos!

Maxwell Siqueira 


\section{APRESENTAÇÃO}

Esse trabalho apresenta uma proposta de ensino sobre a Física de Partículas Elementares que, tem como objetivo levar uma descrição atual e mais detalhada da estrutura da matéria. Para isso, utiliza-se de textos adaptados para uma linguagem mais acessível à sala de aula e de atividades desenvolvidas que auxiliam a compreensão dos conceitos estudados.

A aplicação contou com a colaboração de um grupo de professores da rede pública estadual da cidade de São Paulo. Estes professores participam de um projeto desenvolvido no LaPEF/FEUSP (laboratório de pesquisas em ensino de Física) de atualização curricular das escolas públicas estaduais e já haviam colaborado com a aplicação de um curso de Dualidade Onda-Partícula (Brockington, 2005).

Para analisar a estrutura do curso, buscou-se na didática da Ciência uma ferramenta de análise que, já havia se mostrado apta para isso. Essa ferramenta é a Transposição Didática.

A Transposição Didática tenta refazer a trajetória percorrida por um determinado saber, deste a sua origem até chegar à sala de aula, definindo três níveis de saber: Saber Sábio, Saber a Ensinar e Saber Ensinado. Para analisar as transformações ocorridas no saber, ela lança mão de algumas regras (atributos) e características que este saber deverá apresentar para que, de fato, se torne um saber de sala aula. Com essas regras e características, fizemos a análise da estrutura do curso.

Ao final, mostra-se o sucesso obtido com a elaboração e aplicação da proposta. Indicando que é possível levar a Física de Partículas Elementares para sala de aula, numa perspectiva inovadora, tanto em relação ao currículo quanto a metodologia.

Assim, conseguiu-se alcançar um sonho há muito tempo perseguido por mim, o de levar a Física de Partículas Elementares para sala de aula, tentando motivar os alunos do Ensino Médio a conhecer mais da Ciência, da mesma maneira que ocorreu comigo. 


\section{RESUMO}

Na perspectiva da inserção da Física Moderna e Contemporânea, foi elaborada uma proposta de Física de Partículas Elementares através de uma seqüência didática, com textos e atividades que buscaram levar esse tópico para jovens do Ensino Médio das escolas públicas do estado de São Paulo.

Para analisar a seqüência didática elaborada, buscou-se na didática da Ciência um instrumento teórico, a Transposição Didática. Essa teoria já havia sido utilizada para analisar outras propostas de cursos, mostrando-se conveniente para analisar o processo de adaptação do saber, desde sua origem até à sala de aula.

Assim, esse trabalho, elaborou, aplicou e analisou uma proposta de ensino de tópicos de Física de Partículas Elementares para jovens do E.M. de escolas públicas na cidade de São Paulo. Concluindo que é possível levar este conhecimento para à sala de aula, estando ao alcance dos alunos e dos professores. 


\section{ABSTRACT}

In the perspective of Modern and Contempory Physics insertion, was elaborate a proposal of Elementary Particles Physics through a didactic sequence, with texts and activities that to introduce this topics for the secondary school young's of the public network of the state of .

To analyze this didactic sequence, we searched in the science didactic a theorical instrument, the Didactic Transposition. This theory there was utilized to analyze other curses proposals, shows appropriate to analyze the knowledge adaptation process, since your origin until the classroom.

Thus, this work, elaborated, implemented and analyzed an proposal of teaching Elementary Particles Physic's topics. Concluding that is possible to lead this knowledge to the classroom, to be on students and teachers reach. 


\section{CAPÍTULO 1}

\section{O ENSINO DE FÍSICA E A NECESSIDADE DE ATUALIZAÇÃO CURRICULAR}

\section{1 - Introdução}

A ciência, há algum tempo, vem fazendo parte de nossas vidas e, a cada dia, o seu desenvolvimento dela traz para a humanidade mais tecnologia e conforto. Mesmo assim, grande parte das pessoas pouco sabem por que e como toda essa tecnologia foi e pode ser gerada, não compreendendo as novas ferramentas tecnológicas. Um dos motivos para a manutenção desse quadro, está no ensino de Ciências nas escolas, que é de certa forma ultrapassado, seja pela metodologia tradicional ou pelo conteúdo que pouco condiz com a sociedade moderna. Um ensino que se mostra desatualizado com a realidade do estudante, fazendo com que a Ciência apresentada não contribua para o crescimento do jovem na sociedade, não conseguindo assim, atrair o seu interesse.

Além disso, a sociedade contemporânea tem se tornado cada vez mais competitiva, exigindo cada vez mais, pessoas bem qualificadas e bem informadas. Espera-se então, que o ensino possa também ter essa conotação, ou seja, um ensino de qualidade, que, de fato, contribua para formação de cidadãos bem qualificados e bem informados.

Assim, é urgente, a elaboração de propostas, para a reformulação dos currículos de Física no Ensino Médio, buscando inová-los e atualizá-los. Um currículo renovado, que traga um maior aprimoramento dos conhecimentos dos alunos com as novas tecnologias.

No entanto, essa reformulação do currículo de Ciência, aguardado com tanta ansiedade por profissionais da educação, vem sendo discutida desde o final da década de 1980, indicando algumas tendências e os possíveis caminhos para se obtê-la. Estudos indicam o ensino cognitivista, História e Filosofia da Ciência, inserção da Física Moderna e Contemporânea, Interdisciplinaridade e a abordagem do cotidiano dos 
alunos como caminhos para se chegar a esta renovação, sendo mesmo possível um currículo que vislumbre mais de um desses aspectos.

Dentre esses possíveis caminhos a serem seguidos, destacamos a inovação através da inserção de tópicos de Física Moderna e Contemporânea (FMC) no Ensino Médio (E.M.). Acreditamos que esses tópicos podem atualizar o currículo das escolas, seja através de conteúdos de Física mais recentes, que mostrem as pesquisas de ponta e as fronteiras da Ciência, seja inovando os conteúdos já existentes, sob o ponto de vista da Ciência Moderna, levando a uma nova visão da natureza e dos fenômenos.

A inserção da FMC, permitirá uma maior aproximação do jovem à Ciência Moderna, através da melhor compreensão do funcionamento dos aparelhos modernos, do entendimento de como a Ciência evoluiu, bem como seu funcionamento, e ainda, possibilitará a esse jovem compreender as discussões sobre fatos e acontecimentos contemporâneos, divulgados pela mídia.

Espera-se que o ensino de Física, na escola média, contribua para a formação de uma cultura científica efetiva, que permita ao indivíduo a interpretação dos fatos, fenômenos e processos naturais, situando e dimensionando a interação do ser humano com a natureza como parte da própria natureza em transformação. (BRASIL, 1999, p.229)

Assim, espera-se que a Ciência levada aos alunos nas escolas, contribua de alguma forma, para o seu crescimento pessoal enquanto cidadãos, levando-os a compreender melhor a Ciência, em seus aspectos históricos, filosóficos e epistemológicos, entendendo também porque tanto se investe em experimentos como o projeto Genoma, novos aceleradores e detectores de partículas ou telescópios mais potentes, que, à primeira vista, em nada se relacionam com a sua vida, com o seu cotidiano.

Desta forma, vemos que existe uma tendência nacional e internacional de atualizar o currículo de Física. Mesmo assim, são escassas as propostas que levam a FMC para sala de aula, que procuram sinalizando as metodologias mais prováveis para que isso ocorra, indicando alguns obstáculos e trazendo dados que possam contribuir para a melhoria de novas propostas. 


\section{2 - Por que inserir Física Moderna e Contemporânea no ensino médio?}

Terminado o século XX e iniciado o século XXI, constata-se que pouca coisa mudou no ensino de Física do E.M. no Brasil. A Física escolar atual é toda ela desenvolvida entre os séculos XVII e XIX. Uma Física de aproximadamente dois séculos atrás, reduzindo-se apenas à Cinemática, Leis de Newton, Termologia, Óptica geométrica, Eletricidade (que, na maioria das vezes, se resume a eletrostática, que talvez chegue ao estudo da corrente elétrica) e Circuitos elétricos simples (com resistores ou capacitores).

Um dos papéis da escola é a transmissão do conhecimento gerado pela humanidade. Porém, os jovens que freqüentam as escolas, vivem em uma sociedade altamente tecnológica e competitiva, rodeados de aparelhos modernos e sofisticados, onde o mercado de trabalho exige, cada vez mais, profissionais bem qualificados. Isso não quer dizer que esperamos que a escola forme profissionais, mas acreditamos que ela deva contribuir para uma formação científica melhor do que a que se tem atualmente. Além disso, a mídia (seja rádio, TV, revistas ou jornais), a todo o momento, divulga novas descobertas em Física. Contudo, o currículo de Física do E.M. não contempla discussões da Ciência Contemporânea1, como destacamos na frase de Carvalho \& Vannuchi (1996, p.7):

\footnotetext{
Vivemos hoje um mundo altamente tecnológico - fibra ótica, código de barras, microcomputadores etc... - e o nosso ensino ainda está em Galileu, Newton, Ohm - ainda não chegou ao século XX. Estamos no último qüinqüênio do século $\mathrm{XX}$, mas em termos de ensino estamos muito longe de seu início.
}

Assim, devemos repensar o currículo de Física, que está em vigor em nossas escolas; sendo necessário sua reformulação para que possa contribuir melhor para a formação dos jovens, tendo em vista as exigências da sociedade moderna, e a necessidade de compreensão do mundo ao seu redor.

\footnotetext{
${ }^{1}$ Classificamos como Contemporâneo, tudo aquilo que foi feito na Física da década de quarenta até os dias de hoje. (OSTERMANN; MOREIRA, 2001, p.138)
} 
Desta forma, essa reforma (no sentido de atualização e modernização do currículo) servirá para que o aluno tenha uma "nova" Física, e assim, um contato com um novo mundo, levando o ensino de Física a condizer melhor com o seu tempo e com o cotidiano do aluno, podendo talvez despertar um maior interesse do mesmo.

Essa preocupação vem sendo exposta, há alguns anos, por vários pesquisadores na área de ensino, tanto no âmbito internacional, como Gil et al. (1987); Stannard (1990); Kalmus (1992); Swinbank (1992), quanto no âmbito nacional como Terrazzan (1992, 1994); Fagundes (1997); Valadares \& Moreira (1998); Pinto \& Zanetic (1999); Ostermann \& Moreira (2000, 2001), Brockington (2005), levando essa discussão para os encontros, simpósios e artigos em revistas na área de ensino de Física.

Esses pesquisadores apontam a inserção da FMC, como necessária para que os jovens possam compreender os fenômenos ligados às situações vividas por eles, ou seja, os fenômenos modernos ligados ao seu cotidiano, contribuindo para o exercício de sua cidadania. Como destaca Terrazzan (1992, p.210):

A tendência de atualizar-se o currículo de Física justifica-se pela influência crescente dos conteúdos contemporâneos para o entendimento do mundo criado pelo homem atual, bem como a necessidade de formar um cidadão consciente e participativo que atue nesse mesmo mundo.

Contudo, pode-se questionar sobre o não conhecimento de grande parte das pessoas sobre esses tópicos ; até certo ponto podemos concordar com isso; porém, se, como cidadãos, não pretendem ficar à margem na sociedade, deverão saber discutir sobre o que ocorre na Ciência atual, sabendo se posicionar perante as discussões acerca dessa área de conhecimento.

Temos aqui, uma primeira indicação para atualização do currículo de Física nas escolas brasileiras, um currículo que contemple um ensino mais ligado ao dia-a-dia do aluno. Contudo, esse currículo de Física, que se aplica nas escolas hoje, vem sendo alvo de muitas críticas por parte poder público que procura melhorar o E.M. nas escolas. Essas críticas aparecem, por exemplo, nos Parâmetros Curriculares Nacionais: 
O ensino de Física tem-se realizado freqüentemente mediante a apresentação de conceitos, leis e fórmulas, de forma desarticulada, distanciados do mundo vivido pelos alunos e professores e não só, mas também, vazio de significado. (BRASIL, 1999, p.229).

Não é difícil encontrar currículos que contemplem a aplicação sistêmica de fórmulas, não fazendo o aluno pensar sobre o que está sendo feito, tornando o aprendizado do conteúdo cansativo e desestimulante e sem nenhum significado para os jovens. Levando a uma resistência muito grande à Ciência, em especial à Física.

Os PCN’s buscam, dessa maneira, uma maior atualização do currículo, na tentativa de tornar a educação voltada para o dia a dia, mais atual e com um significado maior, ou seja, contribuindo para formação de um cidadão crítico e participativo.

Com o objetivo de nortear essa atualização do currículo, foi sancionada, em 20 de dezembro de 1996, a Lei de Diretrizes e Bases (LDB) da educação nacional que integrou o ensino médio à educação básica. Com ela vieram também os Parâmetros Curriculares Nacionais (PCN’s), que mostraram uma grande preocupação com a formação dos estudantes enquanto cidadãos críticos e preparados para a vida social.

Os conteúdos, as metodologias e as formas de avaliação serão organizados de tal forma que ao final do ensino médio o educando demonstrara:

I - domínio dos princípios científicos e tecnológicos que presidem a produção moderna;

II - conhecimento das formas contemporâneas de linguagem;

III - domínio dos conhecimentos de Filosofia e de Sociologia necessária ao exercício da cidadania. (BRASIL, 1999, p.31 grifo nosso)

Essas críticas não estão somente na esfera política. Muitos pesquisadores da área de ensino de ciências tecem críticas ao ensino atual. Pinto \& Zanetic (1999, p.7), afirmam:

Estamos nos aproximando do final do século XX e a Física nele desenvolvida está longe de comparecer às aulas de nossas escolas. É preciso transformar o ensino de Física tradicional oferecido por nossas escolas em ensino que contemple o desenvolvimento da Física Moderna. [...] Uma Física que hoje é 
responsável pelo atendimento de novas necessidades que surgem a cada dia, tornando-se cada vez mais básica para o homem contemporâneo, um conhecimento que extrapola os limites da ciência e da tecnologia, influenciando outras formas de saber humano.

Constata-se assim, que a Física levada para sala de aula não condiz com o seu tempo, existindo uma defasagem no ensino dessa Ciência. Ensinamos a Física de séculos atrás; porém vivemos em um mundo moderno, rodeado de tecnologias. Foi o desenvolvimento da Ciência, que fez com que houvesse uma revolução dos objetos ao nosso redor. Então por que não levar a FMC para sala de aula? Valadares \& Moreira (1998, p.121) fornecem alguns elementos para responder essa questão:

\footnotetext{
Em nosso cotidiano deparamos cada vez mais com novos aparelhos eletrônicos e opto-eletrônicos, dispositivos automáticos, sistemas de controle, novas usos do laser em medicina e nas telecomunicações, além de aplicações em várias áreas industriais. Tudo isso e muito mais está presente em casa, nas lojas, nos hospitais, supermercados, carros, aeroportos e por que não, também nas próprias escolas.
}

É claro, que não se espera formar um técnico, conhecedor dos diversos equipamentos modernos, mas ao menos, fornecer uma pequena noção, de como eles funcionam.

Pode-se indagar ainda, que conhecer o princípio de funcionamento dos diversos equipamentos modernos, não faz com que a pessoa viva melhor. Essa é uma falsa impressão; pois, ao conhecer esses princípios através da FMC, a pessoa poderá entender melhor os riscos e perigos que pode correr, ao utilizar esses equipamentos de forma errada, e, além disso, poderá ser inserido em uma discussão mais ampla, sabendo expor suas opiniões e recebendo as informações de forma mais crítica.

Podemos notar que a atualização curricular está ligada diretamente a influência que a Física tem no cotidiano das pessoas. Seja pelo simples desejo de conhecer, seja pela necessidade de formação crítica de um cidadão; isto é, a atualização do currículo de Física é justificada pela inserção maior dos jovens ao conhecimento do mundo a sua volta, como destacam Valadares \& Moreira (1998, p.121): 
É imprescindível que o estudante do segundo grau conheça os fundamentos da tecnologia atual, já que atua diretamente em sua vida e certamente definirá o seu futuro profissional. Daí a importância de se introduzir conceitos básicos da Física Moderna e, em especial, de se fazer uma ponte entre a Física da sala de aula e a Física do cotidiano.

Outros trabalhos corroboram o argumento de Valadares \& Moreira, indicando que a abordagem de tópicos de FMC se faz necessário no E.M., como Terrazzan (1992, p.210):

Aparelhos e artefatos atuais, bem como fenômenos cotidianos em uma quantidade muito grande, somente são compreendidos se alguns conceitos estabelecidos a partir da virada deste século (século XX) forem utilizados na sala de aula.

Assim, esses argumentos estão pautados, na necessidade dos conteúdos de FMC possibilitarem o entendimento e a participação dos jovens no mundo contemporâneo. Isso mostra, que entendimento de mundo, criado pelo homem atual, como aparelhos e artefatos, somente poderão ser compreendidos, a partir do ensino de tópicos relacionados a este campo, ou seja, se queremos que os nossos jovens entendam o funcionamento da tecnologia contemporânea, devemos ensinar a Física referente à ela.

Mas a defesa da inserção da FMC no E.M. não se restringe a esses argumentos. Outros pesquisadores, afirmam que ela pode contribuir para uma visão mais apropriada da Ciência.

Acreditamos que o ensino de Física Moderna e Contemporânea a alunos secundaristas se reveste de grande importância, uma vez que a introdução de conceitos atuais de Física pode contribuir para dar uma imagem mais correta desta ciência e da própria natureza do trabalho científico. (GIL et al., 1987, p.209)

É comum encontrarmos jovens, que acreditam que a Física é algo feito por gênios, sendo levados a criar um estereotipo do pesquisador, do professor e do estudante de Física, como pessoas "loucas", muito inteligentes, que parecem vir de outro mundo. 
Acreditamos que a inserção de tópicos de FMC, pode contribuir para a diminuição desse pensamento, mostrando que a Física é construída por pessoas normais, que dedicam muito tempo de suas vidas, tentando responder as questões que intrigam a humanidade. Assim, o jovem pode estreitar seus laços com a Física, procurando conhecer ainda, que não volte a estudá-la.

Gil et al. (1987) argumenta ainda, que a inserção da FMC, parece ser uma boa oportunidade para reforçar a imagem do desenvolvimento científico, mostrando como a Ciência se desenvolve.

Além dessas duas vertentes de argumentação sobre a inserção da FMC, podemos destacar uma outra, que talvez possa ser mais atrativa e cativante para o aluno. Ao conhecer um pouco mais da FMC, o jovem poderá acessar o mundo com um outro olhar.

É preciso transformar o ensino de Física tradicionalmente oferecido por nossas escolas em um ensino que contemple o desenvolvimento da Física Moderna, não como uma mera curiosidade, mas como uma Física que surge para explicar fenômenos que a Física Clássica não explica, constituindo uma nova visão de mundo. (PINTO \& ZANETIC, 1999, p.7)

Desta forma, a inserção da FMC faz-se necessária, para conceder aos jovens, uma nova possibilidade de leitura da natureza, contrastando com a leitura, a partir da Física Clássica. Aliás, isso pode ser um ponto favorável ao ensino de FMC no E.M., ou seja, através dessa Física, pode-se mostrar uma outra face da natureza, que é desconhecida pelo jovem, tornando-a assim, mais atrativa por não ter sido ainda explorada. Além do mais, ela pode contribuir para uma visão menos linear e acabada da Física, que normalmente é passada aos alunos.

Porém, isso não quer dizer que se deva abandonar a Física Clássica. Pode-se, de uma forma menos traumática e dogmática, inserir a FMC vinculada a Física Clássica, presente na sala de aula. Isso contribui, para uma releitura da natureza pelo aluno, como, por exemplo, no estudo de eletricidade ao estudarmos a carga elétrica, e a constituição atômica e nuclear; discutindo a força responsável pela agregação nuclear, que resiste à grande repulsão coulombiana existente entre os prótons (Menezes e Hosoume 1997). 
Portanto, não é necessário excluir os conteúdos já encontrados na sala de aula, mas dar-lhes uma roupagem nova, mais moderna, ou seja, “apresentar o conteúdo sob um ponto de vista mais moderno." (TERRAZZAN, 1992, p.211). Contudo, deve-se tomar cuidado para que esse novo conteúdo não seja ensinado de maneira tradicional. Assim, acreditamos que novos conteúdos, como tópicos de FMC, necessitam de abordagens e metodologias diferentes para o seu aprendizado.

Muitas pesquisas já apontaram à necessidade de se introduzir a FMC no Ensino Médio (TERRAZZAN, 1994; PINTO \& ZANETIC, 1998, entre outras). Porém poucas, ou quase nenhuma, contêm propostas de ensino. Não há uma reflexão, sobre quais conteúdos podem ser levados para sala de aula. Segundo, Ostermann \& Moreira (2000, p.392) "apesar de todos os argumentos apresentados, ainda faltam propostas que levem tópicos de Física Moderna e Contemporânea para as escolas secundárias." É importante, pois, investir na introdução de alguns tópicos de FMC no ensino médio, avaliando os resultados da aprendizagem em condições reais de sala de aula.

Apesar do quadro escasso de propostas, alguns trabalhos apontam os diferentes obstáculos encontrados na inserção de tópicos de FMC, como: a falta de material didático sobre esses tópicos (Ostermann \& Cavalcanti, 1999), a falta de formação adequada do professor (Pinto \& Zanetic, 1999; Costa et al., 1997) e o formalismo matemático das teorias modernas e contemporâneas (Pinto \& Zanetic, 1999). Contudo, esses obstáculos podem ser superados com propostas bem estruturadas e com a consciência dos empecilhos que poderiam ser encontrados (Siqueira \& Pietrocola, 2005).

A falta de material para professores é um aspecto que começa a ser combatido; através de iniciativas de pesquisadores, que tentam divulgar a FMC em uma linguagem mais adequada. Contudo, esse material não se encontra adequado para sala de aula, ou seja, ainda não há material que possa ser diretamente aplicado pelo professor, como, por exemplo, um livro didático satisfatório.

Já a formação do professor, se torna um aspecto de suma importância, pois como podemos pensar na inserção da FMC, se não temos profissionais formados adequadamente para isso? Os cursos de licenciatura em Física têm poucas disciplinas 
que abordam tópicos de FMC, e ainda, são mais raros, os cursos de formação continuada para professores que visam trabalhar esses tópicos. Porém, para que o professor possa ministrar um curso de FMC no E.M., é necessário, que ele saiba, não somente o conteúdo, mas também como aplicá-lo, pois se trata de uma abordagem diferente da tradicional.

Quanto ao problema do formalismo matemático, uma possível saída é a abordagem conceitual da FMC que, apesar de sofrer uma perda, pode ser recompensada com uma discussão mais conceitual e fenomenológica (qualitativa) do conteúdo. Acreditamos que esse tipo de abordagem não comprometa o aprendizado da FMC.

Quanto à aprendizagem, Ostermann \& Moreira (2001), destacam que é um erro pensar que os alunos não têm capacidade de aprender conteúdos de FMC. Segundo, estes autores:

É viável implementar tópicos de Física Moderna e Contemporânea em escolas de nível médio. Os alunos podem aprendê-los, quer dizer, não encontramos obstáculos de natureza cognitiva e os pré-requisitos foram superados. [...] as dificuldades de aprendizagem não foram diferentes das usualmente enfrentadas com conteúdos da Física Clássica. (OSTERMANN \& MOREIRA, 2001, p.147)

As discussões e preocupações sobre a inserção de tópicos de Física Moderna e Contemporânea na escola média, não ficam restritas aos educadores e pesquisadores em ensino. Há bastante tempo, alguns físicos teóricos e experimentais vêm discutindo sobre o assunto. Em um destes encontros, denominado LISHEP2, vários físicos renomados, destacaram a importância de se levar a Física Moderna, em especial a Física de Partículas, para o estudante secundarista. $\mathrm{O}$ enfoque desse encontro foi tentar oferecer aos professores materiais que pudessem contribuir para a inserção da Física de Partículas nos três últimos anos do ensino básico brasileiro.

Porém, não basta somente fornecer material didático aos professores, é preciso investir em formação, mesmo porque, não podemos inserir a FMC nos moldes

\footnotetext{
${ }^{2}$ LAFEX International School on High Energy Physics, realizado no Rio de Janeiro, durante os meses de janeiro e fevereiro de 1993. Esse é um evento que ocorre a cada dois anos.
} 
tradicionais da Física Clássica, pois, assim, corre-se o risco de se ter somente mais conteúdos no currículo, sem proporcionar aos alunos, a chance de reconhecer as diferenças existentes entre a Física Clássica e a Moderna.

Comparativamente, outras áreas da Ciência, como a Biologia e a Química, já conseguiram incluir em seu currículo do E.M. tópicos modernos, fazendo parte efetiva de sua programação. Por exemplo, os livros dessas áreas abordam assuntos como o Genoma, a estrutura do DNA, fotossíntese, níveis de energia nas camadas eletrônicas, o spin dos elétrons, entre outros. Todos esses conteúdos fazem parte de uma Ciência Moderna e Contemporânea, desenvolvida no século XX e que já se encontra em sala de aula. Infelizmente, em contraste a esse quadro, não se vêem, ainda, tópicos ligados a Física desse século sendo desenvolvidos na sala de aula.

Deve-se lembrar ainda que, para um grande contingente de nossos alunos, a Física escolar de $2^{\circ}$ grau será o único contato, na sua escolarização formal, com a Ciência Física, como destaca Terrazzan (1992, p.212): “[... constatamos que a Física desenvolvida neste nível de ensino ( $2^{\circ}$ grau) é o último contato formal com esta ciência para grande percentual dos alunos.”. Representando, assim, a última ocasião de contato com uma Ciência Moderna em sua formação básica.

Desta forma, constata-se, que há argumentos para que a FMC esteja presente no E.M. e que podem apresentar obstáculos, contudo, eles podem ser superados. Resta também delimitar, quais seriam os tópicos a serem levados, auxiliando as propostas futuras, para que estas, possam levar esses aspectos em consideração. 


\section{3 - Por que Física de Partículas?}

Na perspectiva de inserção da Física Moderna e Contemporânea, alguns trabalhos já foram feitos na tentativa de delinear os possíveis tópicos que poderiam ser levados para a sala de aula.

Em um desses trabalhos, Stannard (1990) relata um levantamento feito com alunos iniciantes, nas universidades do Reino Unido, mostrando que tópicos como relatividade restrita, partículas elementares, teoria quântica e astrofísica estão entre os tópicos que mais influenciam os alunos na escolha de carreiras científicas.

Em um trabalho bem parecido com o anterior, Kalmus (1992) se refere a um levantamento feito em 1984, com os calouros de Física do Reino Unido. Por meio de um questionário, enviado a todos os departamentos de Física daquele país, foi pedido aos alunos que listassem, por ordem de preferência, três tópicos que influenciaram na escolha da carreira. Os três com maior índice de indicação foram: relatividade, astronomia e partículas elementares.

Esses trabalhos servem como indicativos de tópicos que poderiam ser trabalhados no E.M., tendo o aval dos próprios alunos. Pode-se assim, justificar a inserção de tópicos de FMC, devido à influência sobre os jovens na escolha da carreira profissional. Segundo Ostermann e Cavalcanti (1999, p.267):

A tendência em inserir tópicos de FMC justifica-se, entre outras razões, pela necessidade de atrair jovens para as carreiras científicas. São eles os futuros pesquisadores e professores de Física. É fundamental também despertar a curiosidade dos estudantes e ajudá-los a reconhecer a Física como empreendimento humano e, portanto, mais próximo a eles.

Mas não são somente os trabalhos fora do Brasil, que fazem esses apontamentos. Um levantamento, com resultados parecidos aos anteriores foi feito no Brasil, relatado por Ostermann \& Moreira (2000). Nesse trabalho, foram feitas entrevistas com 54 físicos, 22 pesquisadores em ensino de Física e 22 professores de Física do ensino médio, através da técnica Delphi (Ostermann \& Moreira, 1998) para que os entrevistados apontassem quais seriam os tópicos que deveriam ser levados para o E.M. 
Essa entrevista foi feita em três momentos, chegando a seguinte relação de tópicos de FMC que poderiam ser inseridos no ensino médio:

Efeito fotoelétrico, átomo de Bohr, leis de conservação, radioatividade, forças fundamentais, dualidade onda-partícula, fissão e fusão nuclear, origem do Universo, raios-X, metais e isolantes, semicondutores, laser, supercondutores, partículas elementares, relatividade restrita, Big Bang, estrutura molecular e fibras ópticas. (OSTERMANN \& MOREIRA, 2001, p.138)

Pode-se notar, que nessas pesquisas, entre os vários tópicos de FMC, encontramse, em todos os três trabalhos, a relatividade, as partículas elementares e a astrofísica. Dentre esses destaca-se, particularmente, as partículas elementares.

Apesar de ser apontado entre os três mais influentes para a escolha da carreira dos jovens, o destaque dado a esse tópico nesta pesquisa, tem um caráter, inicialmente, bem pessoal. Essa particularidade está ligada diretamente à influência que esse conteúdo teve na escolha da minha carreira profissional, levando-me a interesse por essa área. Ao ter contato pela primeira vez com as Partículas Elementares, (através de uma reportagem trazida na revista "Super Interessante"), fiquei encantado com uma Física que não chegou a mim pela escola. Foi então que resolvi seguir a carreira de Física, na esperança de estudar e compreender essa área que tanto me chamou a atenção e me cativou.

Encontram-se também na literatura, autores que acreditam que, entre os tópicos da FMC, a Física de Partículas (partículas elementares e suas interações) deveria ter prioridade de abordagem no E.M. Uma desses autores é Alvarenga3. Em uma mesa redonda ocorrida na $1^{\text {a }}$ Escola Internacional de Física de Altas Energias do LAFEX (LISHEP 93), que debatia a preocupação e o interesse em levar a Física de Partículas para a escola, Alvarenga apontou os seguintes motivos para termos essa área de conhecimento no E.M.:

Os conhecimentos dessa área, possibilitam ao estudante um certo aprofundamento dos estudos de Cosmologia, levando-o a uma visão mais racional do mundo em que vivemos, a discussões mais equilibradas sobre a 
origem e o fim do Universo, colaborando para afastamento das crendices e superstições, muito comuns entre os jovens.

$\mathrm{O}$ assunto pode ser tratado historicamente, com apresentação das diversas teorias que se sucederam, levando os alunos a perceberem que os conhecimentos científicos não são verdades absolutas (aspecto importante da visão atualizada das ciências).

O sucesso das pesquisas nesta área, altamente dependentes das tecnologias avançadas, que possibilitaram várias descobertas, evidenciaram a interdependência entre o desenvolvimento dos conhecimentos científicos e tecnológicos, sem priorização de um deles.

São tópicos fundamentais e sua aprendizagem facilita a compreensão, com maior profundidade, de muitos outros assuntos, tanto no campo da Física, quanto no de outras ciências (química, biologia, geologia, etc.). (ALVARENGA, 2000, p.191)

Verifica-se que o primeiro argumento está centrado na evolução do Universo. Essa é uma questão pela qual, a humanidade se interessava há algum e, nesse momento, continuamos nos a questionar sobre nossa existência (De que é feito o Universo? Qual é a sua origem? Como ele chegou a ser como ele é hoje? Qual é o seu fim? O Universo está em expansão ou contração? Será possível chegarmos a Marte? Existe vida fora da Terra?). Essas questões podem servir, como temas motivadores da aula e, a partir dessas discussões, pode-se introduzir a Física de Partículas. E, não só essas questões poderiam ser levantadas, como destacam Ostermann \& Moreira (2001, p.139):

[...] talvez, de certa forma, partículas elementares esteja vinculado a questões mais básicas da Física, ou quem sabe, nos remete a problemas filosóficos (como buscar a ordem na diversidade)... Como funciona o Universo é uma pergunta que tem fascinado os cientistas há séculos e também o homem como espécie e é, em certo sentido, a pergunta-chave desta área da Física.

Conjuntamente a essas questões filosóficas, a Física de Partículas pode se prestar a fornecer uma visão de um novo mundo: o mundo microscópico, levando um conhecimento novo e mais atual sobre os constituintes da matéria, proporcionando um maior entendimento sobre a estrutura dos corpos e talvez a compreensão de alguns

\footnotetext{
${ }^{3}$ ALVARENGA, Beatriz in: CARUSO, Francisco; SANTORO, Antonio. Do átomo grego à Física das interações fundamentais. Rio de Janeiro. AIAFEX, p.179-196, 2 edição, 2000.
} 
fenômenos ligado à estrutura da matéria. Desta forma, os alunos poderão ter uma nova leitura do mundo ao seu redor, ou seja, uma nova interpretação do mundo.

\footnotetext{
O ensino da Física de Partículas pode mostrar uma visão contemporânea do átomo, tentando romper com o modelo planetário tão freqüentemente apresentado nas aulas de química.

Pode servir para uma releitura da Física clássica, como por exemplo, as interações que do ponto de vista da FMC, são entendidos através da troca de uma partícula mediadora. (OSTERMANN \& MOREIRA, 2000, p.394)
}

A Física de Partículas, pode gerar também, certo grau de estranheza e desconforto ao apresentar conceitos que fogem às concepções clássicas que os alunos têm, como por exemplo, a diferença de massa existente entre os quarks que formam o próton quando estão ligados (938 MeV/c2) e quando estão "separados" (aproximadamente 12 $\mathrm{MeV} / \mathrm{c} 2)$.

Além disso, a Física de Partículas como uma Ciência Contemporânea, pode contribuir para a visão mais adequada da ciência, colaborando mais ainda para uma reinterpretação da Física Clássica e mostrando ao aluno, como a Ciência é dinâmica, como ela se desenvolve, a contribuição dos diversos cientistas para se chegar a um conceito e como o papel da experiência se torna crucial e difícil de ser realizado, sendo necessário o investimento e cooperação de diversos países e cientistas.

A Física de Partículas é uma área da Física muito dinâmica, que está em uma constante busca pelos menores constituintes da matéria, investigando incessantemente sua natureza. "Investigar a natureza da matéria tem sido uma obsessão para os físicos que, obstinadamente, buscam novos modelos para a natureza íntima da matéria." (MOREIRA, 1989, p.125). E hoje, mais do que nunca, isso vem sendo feito com mais afinco, levando a novas questões, na tentativa de elaborar modelos melhores da natureza.

No uso desses modelos, como os modelos atômicos e da estrutura das partículas, utilizada na Física de Partículas, esse aspecto pode prestar uma grande contribuição ao ensino da Física, sobre o entendimento do que são os modelos na Ciência, já que para tentar descrever a natureza da matéria, muitas vezes a Ciência faz uso deles, por não se 
ter acesso direto a essa natureza. Contudo, apesar de desempenhar um papel importante nas teorias científicas, os modelos utilizados em Ciência dificilmente são discutidos em sala de aula e muito menos nos livros didáticos. Como queremos ensinar Ciência se não procuramos discutir uma das principais ferramentas científicas para o entendimento da natureza, que são os modelos científicos?

Desta forma, a Física de Partículas, torna-se um conteúdo adequado para mostrar o processo científico de validação de teorias, bem como o funcionamento da Ciência atual na busca pela compreensão da natureza.

Um outro aspecto também, justifica a inserção da Física de Partículas: é muito comum vermos jovens indagarem sobre pesquisas atuais feitas em Física, pois leram em alguma revista ou algum outro meio de divulgação. Esses meios não têm muito rigor científico, mas são eles que levam as novas tecnologias e as pesquisas mais recentes ao leigos e interessados no assunto.

Como educadores, não podemos deixar que esses assuntos cheguem aos jovens somente pelos meios de divulgação. Pode-se e deve-se discutir esses assuntos na sala de aula. Desta forma, os jovens, poderão entender melhor os artigos das revistas de divulgação científica e compreenderão porque os cientistas fazem essas pesquisas, tendo um posicionamento mais crítico, perante esses artigos veiculados pela mídia.

Existem ainda, alguns valores intrínsecos que o ensino da Física de Partículas poderá trazer. Primeiro, por apresentar a descrição da matéria através de um modelo mais atual, condizerá com as teorias contemporâneas desenvolvidas nas grandes instituições de pesquisa, tanto nacionais como internacionais. Segundo, trabalhará os significados atribuídos a algumas palavras, no contexto da Ciência, como o significado da palavra "ver".

Em Física de Partículas, os objetos estudados não são vistos de maneira direta, como uma pessoa, um livro, mas sim de forma indireta, através de espalhamento de partículas, mostrando assim, como teorias podem ser desenvolvidas e comprovadas através da detecção indireta de partículas (esse é um aspecto que me levou a buscar mais conhecimento sobre as partículas elementares, já que não podia conceber como o 
ser humano poderia descrever objetos tão pequenos através de teorias. Os quarks, por exemplo, pareciam-me muita especulação. Hoje sei, que não são apenas especulações que alimentam as teorias e sim evidências experimentais, tornando a experiência um aspecto fundamental na validação da teoria). Aqui, cabe também, discutir a mudança de significado das palavras "cor" e "sabor", mostrando que o conceito não é definido pela palavra, mas pelo significado que é atribuído a ele, que depende é claro do contexto onde foi definido. Assim, mostra-se que o significado dessas palavras não é o mesmo daquele do nosso dia a dia.

O ensino da Física de Partículas, poderá esclarecer melhor também, a tecnologia moderna, estreitando o contato do jovem com alguns aparatos. Nesse caso, pode-se trabalhar, por exemplo, a geração da energia nuclear - como funciona uma usina nuclear, como é feita a radiografia e a ressonância magnética, bem como outros equipamentos modernos que tanto se houve dizer, mas pouco se sabe. Esses temas podem ser trabalhados como motivadores para estudar a Física de Partículas ou serem trabalhados paralelamente como exemplos.

Desta forma, esse conhecimento terá uma conexão maior com o dia a dia do aluno, e assim, ele poderá entender e discutir melhor as questões sobre a Ciência que, em alguns casos, poderiam ser de seu interesse, mas não tinha como fazer isso.

Com tudo o que foi argumentado a favor da inserção da Física de Partículas no E.M., com toda a contribuição que ela possa trazer para o ensino de Ciências, ainda não se têm propostas que procuram levar essa área de conhecimento para as escolas, sendo importante, desta forma, investir em propostas que possam, de fato, levar esse conhecimento para o E.M., considerando aspectos importantes para o ensino, como por exemplo, a aprendizagem, em um ambiente real e natural que é a sala de aula.

Mas ainda, apesar da grande fascinação que a Física de Partículas pode criar nos jovens alunos, nos frustramos por saber que esse conteúdo não está no E.M., e muitas vezes não se encontra nem nos currículos das licenciaturas em Física das Universidades brasileiras.

É fácil constatar o grande fascínio que a Cosmologia e a Física de Partículas exercem sobre o jovem e que, entretanto, é igualmente grande a sua 
frustração ao constatar que estes assuntos não são objetos de estudo e de discussão na escola. (CARUSO \& SANTORO, 2000, p.43)

Devemos, assim, começar a pensar em propostas que possam ser levadas para sala de aula e que possam fornecer dados, contribuindo para traçar caminhos mais sólidos, não somente para a inserção da Física de Partículas, mas também da Física Moderna e Contemporânea na escola. Levando um novo conhecimento para os alunos, buscando despertar o interesse pela Ciência, mesmo naqueles que não seguirão a carreira de cientistas ou de professores de Ciência.

$\mathrm{Na}$ tentativa de contribuir para a mudança desse quadro, visamos com esse trabalho, elaborar uma proposta que aborde tópicos de Física de Partículas para o ensino médio, com o objetivo de atualizar o currículo e atrair o jovem para a aprendizagem da Ciência e, para uma outra forma de conhecer o mundo que o cerca. 


\title{
CAPÍTULO 2
}

\section{UMA ÁREA DE CONHECIMENTO CONTEMPORÂNEO: FÍSICA DE PARTÍCULAS ELEMENTARES}

\author{
"Em ciência devemos \\ interessar-nos pelas coisas e não \\ pelas pessoas."
}

Marie Curie

\section{1 - Introdução}

$\mathrm{Na}$ história da humanidade, uma questão sempre intrigou muito o homem: quais seriam os menores constituintes da matéria? Ou seja, quais seriam os tijolos básicos da construção de toda a matéria do Universo? Essa questão levou, no último século, ao desenvolvimento de uma das grandes áreas da Física Contemporânea: a Física de Partículas Elementares (esta denominação está em crescente desuso, pois partículas que hoje são elementares, freqüentemente deixam de sê-lo quando regiões menores do espaço são investigadas. A terminologia Física de Altas Energias está sendo mais utilizada atualmente). Contudo, as primeiras investigações tiveram início há muito tempo, algo em torno de 26 séculos, se confundido com o desenvolvimento do pensamento humano, como destaca Salmeron (2005, p.43): “ a história das idéias sobre a constituição da matéria é parte importante da história cultural da humanidade, porque é parte da própria história do pensamento."

Assim, apesar da Física de Partículas ser uma área de investigação contemporânea, ela recebeu contribuições de vários "filósofos naturais" do século VI a.C., que tentavam explicar a natureza, através de suas interpretações.

No início, levantavam-se "hipóteses" sobre os constituintes da matéria. Alguns pensavam se existiria um único elemento básico na origem de tudo. Para outros, um conjunto de elementos poderia "construir" tudo à nossa volta. Mais tarde, entre os séculos XVI e XIX, foram apresentadas novas investigações sobre elementos diminutos, como moléculas e o próprio átomo, iniciando a idéia do átomo científico. No final do 
século XIX e início do século $\mathrm{XX}$, as novas buscas mostraram, que o átomo era constituído de partes. Com isso, uma nova fronteira da ciência estava aberta, dando origem a Física Nuclear, Atômica e das Partículas Elementares, que tentavam desvendar a estrutura da matéria.

No entanto, desde as primeiras investigações até o seu desenvolvimento atual, a busca pelos constituintes básicos da matéria, passou por momentos de crises e de quebra de paradigmas ${ }^{4}$, como as mudanças no conceito de vácuo e de matéria, com sucessões de modelos que tentavam descrever a essência da matéria.

A Física de Partículas Elementares contribuiu também, para uma nova maneira de fazer ciência. Primeiro, porque rompe com o empirismo científico, onde as leis e teorias são formuladas baseadas em experiências que tentam reproduzir o que acontece na natureza. E segundo, porque introduz um novo modo de pensar, com mais liberdade, não se limitando as leis e regras vigentes, ou seja, começa-se a criar novas leis, regras e conceitos (as teorias prevêem partículas que somente foram detectadas mais tarde).

Atualmente a Física de Partículas se preocupa em entender, como se comportam as partículas microscópicas da matéria, estudando as partículas elementares e as interações entre elas, sendo os dois assuntos indissociáveis. Para isso, lança mão da teoria do eletromagnetismo e de mais duas teorias modernas - a Relatividade e a Mecânica Quântica. Juntas, formam um novo campo de conhecimento: a Teoria Quântica de Campos.

$\mathrm{Na}$ tentativa de descrever a natureza, a Física de Partículas utiliza o Modelo Padrão, que descreve o Universo através de poucas partículas elementares. Apesar disso, esse modelo está incompleto. Ainda falta observar algumas partículas, como os bósons de Higgs, responsáveis pela geração da massa para todas as partículas.

\footnotetext{
${ }^{4}$ Concepção kuhnianna de paradigma. Kuhn considera paradigma como as "realizações científicas universalmente reconhecidas que, durante algum tempo, fornecem problemas e soluções modelares para a comunidade de praticantes de uma ciência." (Kuhn, 2003, p.13)
} 


\section{2 - A idéia grega do elemento primordial}

A busca pelo constituinte básico da matéria, vem sendo feita já há bastante tempo, tentando encontrar uma resposta para a questão tão antiga: do que a matéria é feita ou constituída? Os gregos há aproximadamente 2500 anos, começaram a fazer suas investigações e elaborar suas hipóteses sobre esses constituintes. Na formulação de uma visão de natureza que pudesse ser descrita por poucos elementos, surgiram assim, duas grandes correntes filosóficas. (Bassalo, 2000)

A idéia de elemento primordial teve início com o filósofo Tales de Mileto (624546 a.C.), ele acreditava que esse elemento seria a água, pressupondo inicialmente a idéia de causa - a matéria tem uma causa, e a explicação causal da natureza deve ainda ser racional, contraponto-se aos mitos. Para Anaxímenes de Mileto (570-500 a.C.) seria o $a r$, uma vez que o mesmo se reduziria a água por compressão. Xenófenes da Jônia (570-460 a.C.) acreditava ser a terra. Porém, para Heráclito de Éfeso (540-480 a.C.), era o fogo o elemento primordial. Essa corrente ficou conhecida como monista, pois acreditavam que somente um "ente" seria o responsável por formar toda a matéria que existe ao nosso redor.

Na metade do século V a.C., aproximadamente surge um novo movimento que tenta explicar a matéria prima como uma porção única, subdividida em diminutas partes. Essa era a forma como Anaxágoras de Clazômena (500-428 a.C.) imaginava o Universo. Para ele, a matéria prima seria uma espécie de semente (homeomerias) contendo outras sementes em seu interior e, essas, por sua vez teriam outras e assim infinitamente, semente dentro de semente.

Sucedendo essa etapa do pensamento grego singular, veio à idéia de elementos primordiais. Nessa descrição da Natureza, destacam-se Empédocles de Akragas (490431 a.C.) que acreditava no Universo formado pelos quatro elementos: água, terra, fogo e $a r$, podendo combinar-se para formar as diversas substâncias. Esses elementos estariam em constante movimento, o qual seria intermediado pelo amor ou amizade que os uniam, e do ódio ou inimizade que os separavam, indicando as primeiras idéias sobre as forças entre os corpos. Mais tarde, Aristóteles de Estagira (384-322 a.C.), propunha outros elementos: frio, quente, úmido e seco, que agrupados de dois a dois, formavam 
os elementos de Empédocles da seguinte forma: seco e frio daria a terra; seco e quente, o fogo; úmido e quente, o ar, e úmido e frio, a água. Essa corrente filosófica foi denominada de pluralismo.

Leucipo de Mileto (460-370 a.C.) e seu discípulo Demócrito de Abdera (470-380 a.C.), ao contrário da visão de Anaxágoras, acreditavam que todas as coisas eram formadas por um único tipo de partícula: o átomo (indivisível, em grego), eterno e imperecível, que se movimenta no vazio. Propunham também, uma explicação para as diversas propriedades das substâncias (cheiro, sabor e cor, por exemplo), através das diferenças geométricas na forma, na posição e na disposição dos átomos. Essa vertente ficou conhecida como atomista. Nela, a causa das coisas existentes era dada pelo átomo (ser) e o vazio (não-ser).

Assim, essa escola materialista da antiguidade, atribuía realidade àquilo que não fosse matéria, ou seja, o vazio. Esse ente (o átomo) destaca Caruso \& Oguri (1997), ao contrário dos elementos dos outros filósofos, como a água e a terra, não podia ser tocado, nem visto e não teria certas propriedades, como o cheiro, a cor e o sabor. Essas propriedades se manifestariam devido ao movimento dos átomos, garantindo papel fundamental ao vazio, onde esses átomos se movimentariam.

Com essas três vertentes filosóficas, nota-se que "para os Gregos, a compreensão da Natureza passa necessariamente pela busca de um tipo de ordem, o que por sua vez, requer o reconhecimento do que é igual, do que é regular, a capacidade de reconhecer simetrias: tudo em busca de uma Unidade." (Caruso \& Oguri, 1997, p.325)

Mas não eram somente os gregos que buscavam a matéria prima do Universo. $\mathrm{Na}$ China, Tsou Yen (360-260 a.C.) tinha uma concepção pluralista, tendo como elementos básicos a água, a madeira, o fogo, o metal e a terra. Porém, "não eram meras substâncias, já que eram governados pelo dualismo básico dos princípios cósmicos YIN e YANG.” (Bassalo, 2000, p.74)

$\mathrm{Na}$ Índia, os hindus também tinham sua própria concepção, onde os elementos primordiais se ligavam aos sentidos: éter-audição, ar-tato, fogo-visão, água-paladar e terra-olfato, contrastando com a concepção materialista grega, na qual a matéria 
influencia nossos sentidos. Além disso, acreditavam que os quatro elementos de Empédocles eram constituídos de átomos (indivisíveis e indestrutíveis). Por outro lado, devido ao caráter religioso dessa filosofia, havia uma crença de que a alma também seria um elemento primordial do Universo.

\section{3 - As investigações do século X ao XIX}

Já nos primeiros séculos da era cristã, houve uma ascensão do Império árabe. Assim, entre os séculos X e XI, a ciência árabe teve seu período áureo, podendo formular sua própria concepção dos elementos primordiais. Para eles, estes elementos deveriam ser encontrados nos princípios ou nas qualidades das substâncias e, não na substância em si. Desta forma, "o enxofre seria o princípio da combustão (fogo), o sal tinha a qualidade de calcinação (terra) e o mercúrio está ligado ao elemento líquido (água).” (Bassalo, 2000, p.75)

Depois da queda dos árabes, no final do século XI, as idéias gregas voltaram a predominar no Ocidente. Desta forma, as concepções monistas e pluralistas continuaram a ser discutidas e defendidas pelos cientistas da Idade Média e Renascimento.

Entretanto, em 1647, o filósofo e matemático francês Pierre Gassendi (1592-1655) publicou um livro distinguindo pela primeira vez átomo de molécula ${ }^{5}$. Em sua concepção, nos corpos, os átomos se reúnem em grupos, aos quais denominou de moléculas (diminutivo da palavra latim moles, que significa massa ou quantidade de matéria) e, parecia propor que o átomo seria uma parte real da substância, porém invisível e indivisível. Gassendi defendia o atomismo assim como Robert Boyle (16271691) e Isaac Newton (1642-1727).

Já em 1789, foi editada a primeira tabela periódica contendo 30 elementos, elaborada pelo químico francês Antoine Laurent Lavoisier (1743-1794). Ele se baseava no princípio de que "cada elemento de um composto pesa menos do que o composto como todo". 
O inglês John Dalton (1766-1844), em seu livro publicado em 1808, “enfatizou que na Natureza existiam átomos invisíveis e imutáveis" (Bassalo, 2000, p.78), sendo estes, esferas maciças, invisíveis e neutras. Para o mesmo elemento, os átomos seriam idênticos em sua massa, forma e outras propriedades, tendo a possibilidade de reunir vários átomos para formar um átomo composto. Nesse livro, ele ainda apresentou a lei das proporções múltiplas. Assim, Dalton elaborou o primeiro modelo científico, levando em conta as leis empíricas de Proust e Lavoisier, iniciando assim, o atomismo científico.

Vários outros cientistas, como o francês Joseph-Louis Gay-Lussac (1778-1850) e o italiano Amadeo Avogadro ${ }^{6}$ (1776-1856), começaram a investigar melhor as substâncias, com a finalidade de determinar as massas dos átomos e seus volumes. Desta forma, foram formuladas algumas leis que ajudaram a classificar melhor as substâncias na tabela periódica.

Foi então, que em 1869 o russo Dimitri Ivanovich Mendeleiev (1834-1907) e em 1870, o alemão Julius Lothar Meyer (1830-1895) chegaram, independentemente, a tabela periódica dos 63 elementos, relacionando o peso atômico com suas propriedades, seguindo a sequiência $2,8,8,18,18,36$ indicando cada período, o número de elementos que apresentavam as mesmas propriedades e assim, Mendeleiev previu a existência de mais alguns elementos que foram detectados posteriormente, "devido à regularidade e a simetria que esses elementos apresentavam.” (Caruso \& Oguri, 1997, p.327)

\footnotetext{
It is necessary to do one thing or the other either to consider the periodic law as completely true, and as forming a new instrument in chemical research, or to refute it. (MENDELEYEV, 1905, p.185)
}

Previsão como essa, que leva em consideração à regularidade e simetria, se apresentou mais vezes na Ciência, principalmente com a Física de Partículas nos meados do século XX, com a previsão do neutrino, pósitron e outras partículas.

\footnotetext{
${ }^{5}$ Distinção estabelecida oficialmente no $1^{\circ}$ Congresso Internacional de Química, em 4 de setembro 1860

${ }^{6}$ Avogadro observou que átomos podiam se unir para formar moléculas, anunciando a sua hipótese: "sob as mesmas condições de pressão e temperatura, volume iguais de todos os átomos contém o mesmo número de moléculas.” (BASSALO, 2000, p.78)
} 
Os 63 elementos da tabela eram considerados na época, fundamentais. No entanto, quase 40 anos depois, a tabela continha 86 elementos, considerando a periodicidade destacada por Mendeleiev.

O desenvolvimento da química auxiliou as investigações sobre o átomo, reafirmando as idéias gregas do atomismo de Demócrito e, conseqüentemente, a busca por partículas subatômicas. Mas, foi devido às experiências relacionadas ao eletromagnetismo, que o caráter indivisível do átomo foi posto fortemente em dúvida. Para o físico francês André Marie Ampère (1775-1836) e o dinamarquês Hans Christian Oersted (1777-1851), era uma questão de tempo mostrar que o átomo tinha constituintes de carga elétrica. Em 1828, o físico alemão Gustav Theodor Fechner (1801-1887), propôs o modelo de que o átomo consistia de uma parte central massiva que atraía gravitacionalmente uma nuvem de partículas quase imponderáveis. Esse modelo foi melhorado por seu conterrâneo Wilhelm Eduard Weber (1804-1891), colocando a força elétrica no lugar da força gravitacional.

Contudo, a primeira evidência experimental quantitativa sobre a estrutura do átomo, foi verificada pelo físico e químico Michael Faraday (1791-1867) ao descobrir, em 1833, o fenômeno da eletrólise (ação química da eletricidade). "Ele observou que a passagem da corrente elétrica através de soluções químicas fazia com que os metais de tais soluções se depositassem nas barras metálicas introduzidas nessas soluções" (Bassalo, 2000, p.80), fornecendo evidências quantitativas a favor de constituintes carregados no interior da matéria. Essa evidência foi confirmada pela teoria iônica desenvolvida pelo químico Svante August Arrhenius (1859-1927) em 1884, segundo a qual os íons que constituíam a corrente através da solução, nada mais eram do que átomos carregados de eletricidade.

Com a tabela de Mendeleiev e o desenvolvimento da teoria cinética dos gases, o atomismo atingiu o seu auge, sendo aceito pela grande maioria dos cientistas, porém não se conhecia a estrutura desse ente. Apesar de muitas evidências sobre a hipótese do átomo, alguns químicos e físicos rejeitavam ainda essa idéia, como Friedrich Wilhelm Ostwald (1853-1932), químico alemão que publicou um livro em 1909, não utilizando a teoria atômica. Max Planck (1858-1947) também, até o final do século XIX, era receoso 
sobre a idéia, vindo a aceitá-la somente depois, quando foi necessária para a sua lei da radiação. (Ségre, 1987)

\section{4 - As primeiras evidências de partículas subatômicas: a descoberta dos raios X e da radioatividade}

Entre 1895 e 1897, deu-se o início de uma nova era na Física para compreensão da estrutura do átomo, com a descoberta dos raios $\mathrm{X}$, da radioatividade e do elétron. Porém, essas descobertas se devem, às investigações feitas sobre os raios catódicos em tubos de vidro.

Em um estudo feito por volta de 1838, Michel Faraday, observou que a rarefação do ar dentro do tubo favorecia o fenômeno da incandescência, quando ocorria uma descarga elétrica. Julius Plücker (1801-1868) observou em 1858, o desvio desses raios, quando se aproximava um ímã do tubo. Algum tempo depois, em 1869, Johann Hittorf (1824-1914) percebeu sombras projetadas de um objeto na frente do cátodo, sinalizando que a descarga elétrica se originava no próprio cátodo. Mesmo conseguindo melhorar as condições das descargas elétricas, uma questão sobre a natureza dos raios estava em aberto: sabiam que saíam do cátodo em um tubo exaurido de ar; podiam sofrer desvios quando ímãs eram colocados próximos do tubo, apesar de viajarem, aparentemente, em linha reta e por isso produziam sombras de figuras colocadas em seu caminho. Porém, não sabiam o que eram esses raios.

\footnotetext{
Somente com o aperfeiçoamento das técnicas com trabalho com vidro e das máquinas de fazerem vácuo, que foi possível a construção de aparatos, chamados de tubos de raios catódicos, considerados os primeiros aceleradores de partículas. (CARUSO \& OGURI, 1997, p.328).
}

O tubo de raios catódicos, é um aparato que produz descargas elétricas através de gases. Pode-se destacar nesse episódio, uma relação íntima entre a ciência e a tecnologia, que vem se estreitando cada vez mais; tornando-se indispensável ao desenvolvimento da ciência contemporânea. 
$\mathrm{Na}$ tentativa de entender e explicar a natureza dos feixes luminosos que apareciam nos tubos, Wilhelm Konrad Röntgen (1845-1923), fez sua descoberta em 1895. Numa experiência feita com os raios catódicos, Röntgen pôde observar uma cintilação num anteparo tratado quimicamente que, mais tarde, constatou que eram raios provenientes do tubo. Porém não eram os raios catódicos. Como não conhecia a natureza desses novos raios, chamou-os de raios $\mathrm{X}$. A natureza dos raios $\mathrm{X}$ só foi desvendada dezesseis anos depois, quando Max von Laue (1879-1960), através do fenômeno da difração, concluiu que se tratava de uma radiação eletromagnética de alta frequiência. Posteriormente, o raio $\mathrm{X}$ se mostrou muito útil para encontrar elementos químicos como háfnio e rênio, inaugurando assim uma nova área da ciência, a espectroscopia de raios X. Além disso, essa descoberta veio confirmar a Teoria Eletromagnética, mostrando que carga elétrica acelerada, emite radiação eletromagnética.

Em 1896, Antoine Henri Becquerel (1852-1908), investigando se algumas substâncias fluorescentes emitiam raios $\mathrm{X}$ espontaneamente, descobriu que o sal de urânio emitia "raios" espontaneamente, mas não foi capaz de definir sua natureza. No mesmo ano, Ernest Rutherford (1871-1937) observou que nos raios de Becquerel havia duas radiações diferentes, que denominou de alfa e beta. A diferença entre elas, era principalmente, em seu poder de penetração na matéria e a deflexão sofrida, quando passavam por uma região contendo um campo eletromagnético. Em 1900, foram demonstrados que a radiação beta eram elétrons emitidos por núcleos radioativos. Nos anos seguintes, através de medidas de massa e carga elétrica, conclui-se que a radiação alfa era na verdade idêntica ao núcleo do átomo de hélio.

Já em 1897, o casal Marya Sklodowska Curie (1867-1934) e Pierre Curie (18591906), tomaram conhecimento do trabalho de Becquerel. Iniciaram assim, uma investigação com todos os elementos conhecidos, para verificar, se eles possuíam a mesma propriedade do sal de urânio. Descobriram, então, que o tório também emitia essa radiação espontânea, que foi denominado por eles de radioatividade. Posteriormente, eles encontram outros elementos com essa característica, que chamaram de polônio e rádio. (Ségre, 1987)

A descoberta dos raios- $\mathrm{X}$, levou ao descobrimento da radioatividade, ambos contribuíram para a queda do status de indivisibilidade do átomo. Eles forneceram 
indícios e evidências que levaram a uma maior aprofundamento das investigações sobre a estrutura da matéria, levando ao descobrimento do elétron, a primeira partícula subatômica.

\section{5 - Dividindo o indivisível: A descoberta do elétron e os modelos atômicos}

As duas descobertas, mostradas no item anterior, despertaram um maior interesse dos cientistas pela natureza da matéria e dos raios catódicos, inicialmente responsáveis pela produção dos raios-X, que permitiu um novo método de ionização de gases (já que os raios $\mathrm{X}$ têm energia suficiente para retirar elétrons fracamente presos aos átomos). Essas investigações culminaram na descoberta do elétron, em 1896 por Joseph John Thomson (1856-1940), que além de descobrir a primeira partícula subatômica, modificou completamente o modo como a ciência explicava a causa dos fenômenos eletromagnéticos, pois o portador de carga elétrica passou a ser reconhecido como elétron, uma partícula constituinte do átomo ${ }^{7}$. Thomson, concluiu posteriormente, que o átomo não era indivisível, que todas as partículas arrancadas dos átomos tinham mesma massa e carga, qualquer que fosse a espécie de átomo e que, a massa dessas partículas era menor que a milionésima parte do átomo de hidrogênio. Já a carga, ele concluiu que era negativa, em uma experiência, onde coletava cargas em uma espécie de gaiola de Faraday, depois do feixe ter sido desviado por um ímã. Essa experiência já havia sido realizada por Jean Baptista Perrin (1870-1942), nesse mesmo ano. Chegando a conclusão que os raios catódicos eram partículas carregadas negativamente (Ségre, 1987, p.12)

A descoberta do elétron afastou definitivamente a idéia de que o átomo seria o constituinte último da matéria, indivisível, imutável e indestrutível, como sustentava a teoria química da matéria, que tinha suas bases no atomismo de Demócrito.

Depois da descoberta do elétron por Thomson, em 1897, um novo modelo de átomo chega à comunidade científica, substituindo o modelo de Dalton. O novo modelo teria então, as cargas negativas (os elétrons) distribuídas sobre uma esfera carregada

\footnotetext{
${ }^{7}$ A descoberta do elétron mudou a terminologia da eletrostática de fluido elétrico para carga elétrica.
} 
positivamente, sendo o átomo no todo, neutro. Esse modelo "concorria" com o modelo do japonês Hantaro Nagaoka (1865-1950), que descrevia o átomo como sendo semelhante ao sistema solar, "com um caroço central positivo, rodeado por anéis de elétrons com velocidade angular comum semelhante ao planeta Saturno, daí o mesmo ser conhecido como modelo saturniano” (Bassalo, 2000, p.82). Porém, esses novos modelos não tardariam por serem substituídos.

Ernest Rutherford (1871-1937) junto com Frederick Soddy (1877-1956) um químico inglês, esclareceram um fenômeno envolvendo a precipitação de substâncias de compostos radioativos. A substância precipitada "tomava para si” toda a radioatividade, deixando o composto inativo. Depois de certo tempo, o composto tornava-se radioativo novamente, enquanto o precipitado perdia a sua atividade. Para explicar esse fenômeno, eles utilizaram uma idéia contida na transmutação de átomos, indicando que um átomo radioativo tinha uma possibilidade definida de se desintegrar espontaneamente. No entanto, a natureza desse processo estava ainda sem explicação.

Já por volta de 1910, Rutherford analisava junto com seus alunos, fenômenos ligados à passagem de partículas alfa através da matéria. Ernest Marsden (1889-1970), um de seus alunos, relatou ter observado que vez por outra, partículas alfa sofriam desvios em ângulos consideráveis ao invés de passarem em linha reta, como era esperado. De posse dos resultados apresentados por seu aluno, Rutherford concluiu, que o modelo atômico de Thomson não explicava essas observações, pois se as partículas alfa se aproximassem do centro, estariam numa área de carga nula, logo não poderiam sofrer desvios. Rutherford imaginou então, que toda a carga positiva e a massa, estivessem concentradas em um pequeno volume no centro, no qual chamou de núcleo, sendo rodeado por nuvens de elétrons, concordando com o modelo de Nagaoka. Deixando, porém, para a atração eletrostática a função de manter estável o átomo. Surgia assim, uma nova visão de natureza, com a matéria sendo descrita por átomos e esses, constituídos de um núcleo positivo e elétrons girando ao seu redor (Motta, 2005).

As descobertas feitas por Rutherford, levaram a uma nova interpretação da natureza e da estrutura da matéria, ou seja, um novo modelo atômico desde a descoberta do elétron por Thomson. Além disso, suas experiências com o espalhamento das partículas alfa, inaugurou uma nova forma de investigar a estrutura da matéria, 
fornecendo a primeira manifestação das forças nucleares. Esse princípio (espalhamento com partículas alfa) é utilizado até hoje, naturalmente com tecnologia mais avançada para investigar a estrutura de algumas partículas. Essas investigações derrubaram mais uma concepção sobre a estrutura da matéria, mostrando que sólidos podiam ser penetrados. Algo que não era concebido até então, levando a quebra de mais um paradigma.

Continuando com as investigações com partículas alfa, bombardeando agora átomos de nitrogênio (N), Rutherford, observou, em 1919, cintilações que não pareciam ser de partículas alfa e nem de átomo de N. Porém, eram cintilações análogas com as produzidas em colisões com o hidrogênio $(\mathrm{H})$.

Rutherford acreditava, que partículas alfa arrancavam um núcleo de $\mathrm{H}$ ao núcleo de $\mathrm{N}$, transmutando-o no oxigênio (O), segundo a reação: ${ }_{2}^{4} \mathrm{He}+{ }_{7}^{14} \mathrm{~N} \rightarrow{ }_{8}^{17} \mathrm{O}+{ }_{1}^{1} \mathrm{H}$. Concluindo que alguns átomos de $\mathrm{N}$ se desintegravam em $\mathrm{O}$, quando bombardeados por partículas alfa, implicando que o núcleo não seria indivisível e sim, possuía uma estrutura. Desta forma, ele propôs que o "núcleo de $N$ tinha núcleo de $H$, sendo este último uma partícula elementar, chamada de próton, que significa primeiro, em grego.” (Motta, 2005, p.127)

Contudo, esse modelo atômico apresentava inconsistências com o eletromagnetismo clássico. Como Rutherford havia descrito, os elétrons giravam em torno do núcleo e, segundo a Teoria Eletromagnética previa, cargas elétricas aceleradas devem irradiar, perdendo energia continuamente. Logo, o elétron girando em torno do núcleo deveria perder energia, colapsando, indo em direção ao núcleo. E ainda, essa radiação deveria ter um espectro de emissão contínua, algo que não era observado.

Para resolver esse problema, Niels Bohr (1885-1962), propôs um novo modelo atômico. Ele postulou que os elétrons moviam-se em órbitas circulares e seriam estáveis, tendo um momento angular múltiplo inteiro da quantidade $\frac{l h}{2 \pi}(1=1,2,3, \ldots)$. A radiação só poderia ser emitida, quando o elétron sofresse uma transição entre duas órbitas distintas, sendo a frequiência da radiação emitida, dependente das energias das órbitas da transição $\left(E_{n}-E_{m}=h v\right.$, onde $v$ seria a freqüência da radiação). Estava assim, 
garantida, a estabilidade do átomo, sem violar nenhuma lei da Física conhecida até então (Ségre, 1987).

Com a descoberta do núcleo, Rutherford conseguiu desvendar o processo da transmutação dos elementos. Processo no qual, uma substância pode transformar-se em outra. Contudo, para garantir a estabilidade do núcleo, foi necessário inserir elétrons nele e, somente através de uma atração eletrostática, o núcleo poderia ser estável, assegurando desta forma, a existência do átomo. Mas esse modelo do núcleo, não agradava muito Rutherford por apresentar alguns problemas, como por exemplo, a medida do spin de alguns núcleos, feita por medidas experimentais que não correspondiam com os valores teóricos.

Rutherford, de posse de dados experimentais, começou então, a acreditar em um parceiro neutro do próton na formação do núcleo, sendo este, um estado ligado do próton com o elétron. No entanto, ainda não havia conseguido encontrá-lo, tendo que permanecer com o modelo do núcleo contendo elétrons (Barreto, 2005)

\subsection{1 - A descoberta do Nêutron e suas implicações}

Por volta de 1930, Walter Bothe (1891-1957) e Herbert Becker (1887-1955), deram os primeiros passos para a descoberta do nêutron, quando bombardearam, com partículas alfa, uma amostra de berílio (Be). Nessa experiência, detectaram uma radiação penetrante, que podia atravessar, por exemplo, vários centímetros de chumbo, sem sofrer atenuações, sendo interpretada como uma radiação gama. Porém, essa radiação tinha energia maior do que a radiação alfa incidente, acreditando que essa diferença estava ligada à desintegração nuclear (Allard et al., 1974)

Estudando a radiação descoberta por Bothe e Becker, o casal Fredéric Joliot (1900-1958) e Irène Curie (1897-1956), observaram que a radiação podia ejetar prótons da parafina. No entanto, essa observação era muito estranha, porque a massa do próton é muito elevada. "Era como se uma bola de boliche atingisse um caminhão e ambos sofressem récua considerável” (Barreto, 2005, p.156). 
James Chadwick (1891-1974), então aluno de Rutherford, tomou conhecimento da publicação do trabalho de Joliot e Curie e tratou de repetir a experiência, utilizando como fonte a radiação alfa, proveniente do berílio e o polônio, fazendo incidir sobre amostras de hidrogênio, hélio e nitrogênio. "Conseguiu assim, detectar uma componente neutra da radiação, de massa aproximadamente igual ao próton, chamando de nêutron. Divulgando seus resultados em 17 de fevereiro de 1932." (Ségre, 1987, p.188)

Mas o que fez Chadwick interpretar os dados de forma diferente de Joliot e Curie? Sobre a orientação de Rutherford, Chadwick já havia tentado detectar o nêutron em 1923, via emissão de raios gama, sem obter êxito. No entanto, era uma questão de tempo para que fosse descoberta essa partícula. Ao tomar conhecimento das pesquisas de Joliot e Curie, viu uma chance de tentar detectá-lo e assim o fez. Desta forma, Chadwick estava preparado para aceitar o conceito de uma nova partícula, o nêutron.

A reação observada, tanto por Chadwick quanto por Joliot e Curie, na colisão de partículas alfa numa amostra de berílio foi: ${ }_{2}^{4} \alpha+{ }_{4}^{9} \mathrm{Be} \rightarrow{ }_{6}^{12} \mathrm{C}+x$. Contudo, Joliot e Curie, interpretaram essa componente neutra $x$ como uma radiação gama muito energética e nunca haviam pensado que poderia ser uma partícula, como fez Chadwick. "A reação relativa ao berílio podia então ser escrita: ${ }_{2}^{4} \alpha+{ }_{4}^{9} \mathrm{Be} \rightarrow{ }_{6}^{12} \mathrm{C}+{ }_{0}^{1} n$, em que o último símbolo é o nêutron." (Allard et al, 1974, p.114)

A descoberta do nêutron trouxe, para a Física, conseqüências relevantes. Naquela época, todos acreditavam que o núcleo atômico era formado de prótons e elétrons ${ }^{8}$. Porém, essa hipótese apresentava alguns problemas como às diferenças entre as medidas do spin de alguns núcleos com as previsões teóricas. Com o nêutron, esses problemas foram resolvidos e a descrição do núcleo ficou mais bem fundamentada. Como por exemplo, o núcleo de nitrogênio que, no modelo anterior, deveria conter 14 prótons e 7 elétrons, dando massa atômica igual a 14 e carga positiva igual a 7, formando um núcleo de spin fracionário. Porém as medidas experimentais apontavam para um spin inteiro.

\footnotetext{
${ }^{8}$ A hipótese parecia plausível, uma vez que se detectavam elétrons emitidos pelo núcleo no decaimento beta. Além disso, a presença de elétrons no núcleo assegurava a estabilidade dele, uma vez que elétrons e
} 
Com a descoberta do nêutron, o núcleo passou a ser descrito por prótons e nêutrons, dando a massa e a carga do núcleo, e sendo coerente com as medidas do spin desse núcleo, que passou a ser inteiro.

Com a descoberta do nêutron, pensou-se durante várias décadas, que os elementos fundamentais da constituição da matéria seriam os prótons, nêutrons e elétrons, os dois primeiros compondo a estrutura nuclear, que, em conjunto com os elétrons orbitais, formariam os átomos dos elementos da natureza” (BARRETO, 2005, p.158)

\section{6 - Uma grande mudança na ciência: a descoberta da posítron}

Erwin Schrödinger (1877-1961), em 1926, publicou um trabalho onde trazia uma equação para descrever ondas associadas às partículas, conforme havia proposto Louis de Broglie (1892-1986), em sua tese de doutorado. Contudo, era uma equação que não levava a Relatividade em consideração. Por outro lado, Arnold Sommerfeld (18681951) já havia demonstrado que, para elétrons em órbitas em torno do núcleo, correções relativísticas deveriam ser consideradas (Caruso, 2005, p. 138)

Na tentativa de compatibilizar a Mecânica Quântica (equação de Schrödinger) com a Teoria da Relatividade, Paul Dirac (1902-1984), buscava uma equação relativística para descrever o movimento do elétron dentro de um campo.

No caso de partículas livres, ele encontrou a seguinte solução para as energias dos elétrons: $E= \pm \sqrt{p^{2} c^{2}+m^{2} c^{4}}$. Essa solução trazia estados de energia negativos que, a princípio, foi um problema para a Teoria de Dirac.

No entanto, a Mecânica Quântica não excluía a possibilidade de estados negativos ${ }^{9}$. Dirac compreendeu que esses estados negativos não poderiam ser

prótons se atraem mutuamente e, como a massa do elétron desprezível em relação ao próton, a massa do núcleo, seria basicamente a massa dos prótons.

${ }^{9}$ Massa negativa não tem evidentemente nenhum sentido físico, mas pode ser reinterpretado no quadro da uma teoria quântica de campo para o elétron, isto é, uma teoria que encara a possibilidade de serem os elétrons criados e destruídos. 
desconsiderados. Se isso fosse feito, haveria problemas com a própria estrutura da teoria.

Assim, Dirac teve que repensar a idéia de vácuo, para que sua teoria pudesse unir a Mecânica quântica e a Relatividade e, desta forma, abarcar os estados de energia negativa encontradas por ele para os elétrons, como ele mesmo diz:

\begin{abstract}
Se não podemos excluir (os estados de energia negativa), devemos encontrar um método de interpretação física para eles. Pode-se chegar a uma interpretação razoável adotando uma nova concepção de vácuo. Anteriormente, as pessoas pensavam no vácuo como uma região do espaço que é completamente vazia, uma região do espaço que não contém absolutamente nada. Agora devemos adotar uma nova visão. Podemos dizer que o vácuo é uma região do espaço onde temos a menor energia possível. (DIRAC, apud, CARUSO, 2005, p.139)
\end{abstract}

Com isso, ele interpretou o vácuo de uma outra maneira, dizendo ser uma região do espaço onde se teria a menor energia possível, evidenciando que o espaço e a matéria não se excluem mais. Assim, o vácuo deixa de ser aquele espaço totalmente ausente de matéria. Essa nova interpretação do vácuo levou a uma nova visão de mundo, na qual os princípios de simetria ${ }^{10}$ substituíram a matéria como elemento central.

O vácuo então, na interpretação de Dirac, seria o estado de todos os níveis de energia negativa ocupados por elétrons ${ }^{11}$ (desta forma, obedecendo ao princípio da exclusão de Pauli $^{12}$, os elétrons de energia positiva não poderiam fazer uma transição para estes estados), tendo uma estrutura complexa com uma energia total negativa e infinita. Contudo, um elétron do estado negativo poderia ser excitado passando para o estado positivo, deixando no vácuo o que Dirac chamou de buraco. Esse buraco seria interpretado como uma partícula positiva de energia positiva (Caruso, 2005). Esse foi o primórdio da descrição dos processos de criação de partículas e antipartículas.

\footnotetext{
${ }^{10}$ Essas são simetrias matemáticas decorrentes da profunda relação entre matéria e espaço, mantendo a equação de Dirac invariante.

${ }^{11}$ Esse estado de todas energias negativas foi chamado por Dirac de mar de elétrons.

12 Esse princípio diz que dois elétrons com números quânticos idênticos não podem existir em um átomo, que foi estendido para todas as partículas com spin fracionário como o elétron, denominados de férmions.
} 
Por simetria, esse buraco teria massa igual ao do elétron, porém, com carga positiva. Mas a única partícula com carga positiva conhecida na época era o próton, que tem massa quase 2000 vezes maior do que o elétron. Em 1931, Hermann Weyl (18851955) demonstrou que essa partícula deveria ter a mesma massa do elétron, tendo em vista as propriedades de simetria da equação de Dirac.

Weyl disse enfaticamente que os buracos deveriam ter a massa do elétron. Agora, Weyl era matemático. Ele de modo algum era físico. Ele se interessava pelas conseqüências matemáticas de uma idéia, calculando o que pode ser deduzido a partir das várias simetrias. Esse enfoque matemático levou diretamente à conclusão de que os buracos teriam a mesma massa do elétron. (CARUSO, 2005, p.141)

Não demorou nem um ano, para que as previsões teóricas de Dirac fossem confirmadas. Em agosto de 1932, essa partícula foi descoberta por Carl Anderson (1905-1991), dando evidências irrefutáveis para a teoria de Dirac, sobre partículas de massa contrárias à já existentes. Essa foi a primeira partícula elementar a ser encontrada que não "pertencia” ao núcleo.

Por extensão à descoberta do posítron, esperava-se encontrar a antipartícula do próton, com mesma massa e spin, porém com carga elétrica de sinal contrário. E assim, consolidar a teoria de que toda partícula teria a sua antipartícula o que, por conseguinte, levaria a descoberta da antimatéria.

Isso só foi possível, em 1955, quando o acelerador de Berkeley atingiu a faixa de energia necessária para produzir o par próton-antipróton $(\sim 6 \mathrm{GeV})$, conseguindo produzir pela primeira vez o antipróton $(\bar{p})$, por Emilio Gino Ségre (1905-1989) e Owen Chamberlain (1920-2006), abrindo as possibilidades de criar antimatéria. Já haviam detectado o antielétron (posítron) e o antipróton, era questão de pouco tempo a detecção do antinêutron. Logo, poderia produzir um antiátomo ${ }^{13}$, uma antimolécula e

\footnotetext{
13 Átomos de anti hidrogênio (formados por um pósitron e um antipróton) são hoje em dia produzidos rotineiramente para pesquisa em grandes aceleradores. (TIPLER \& LLEWELLYN, 2001)
} 
em seguida a antimatéria e quem sabe, um antimundo com antihumanos ${ }^{14}$. (MENEZES, 2005, p.192)

A simetria entre partícula e antipartícula é uma das verdades da Física atual. Sabese hoje, que para cada partícula, existe uma antipartícula de massa idêntica e carga contrária, de spin igual e estranheza oposta. Contudo, quando ambas se encontram, são aniquiladas mutuamente, transformando-se em raios gama (energia).

Contudo, a idéia de mar de elétrons não era muito confortável, sendo abandonada no final da década de 40, com o desenvolvimento da eletrodinâmica quântica, (QED) por Richard Feynman (1918-1988), que propôs uma interpretação mais simples dos estados de energia negativa. As soluções correspondiam a antipartículas, ou seja, para cada partícula existe uma antipartícula com a mesma massa e carga de sinal contrário. Essa idéia acabou por retomar a idéia do atomismo grego que trazia o ser (átomo) e o não ser (vazio), um antagonismo como partícula e antipartícula.

Desde a sua proposta, pela teoria elaborada por Dirac até a sua descoberta por Anderson, o pósitron (anti-elétron) mudou a visão de mundo do ponto de vista da ciência, modificando os conceitos de elementar e do vácuo, derrubando o processo empirista-indutivista da fabricação da ciência. Além disso, "a descoberta da aniquilação de partícula e antipartícula possibilitaram a descoberta de inúmeras partículas, que ajudaram a descrever o modelo padrão atual.” (Caruso, 2005, p.146)

O descobrimento do pósitron fez com que a Física passasse por uma revisão das idéias acerca da matéria, isso, porque muitos de seus conceitos tiveram que ser revistos, como por exemplo, a definição do que é elementar ${ }^{15} \mathrm{e}$ a aceitação definitiva do aspecto negativo das partículas, e conseqüentemente da matéria, levando a novos fenômenos e a mudança do conceito de vácuo. Consolidando essa nova visão de vácuo, que em sua essência permanece válida até os dias de hoje, auxiliando a fundamentação de

\footnotetext{
${ }^{14}$ Apesar de soar com um tom de ficção científica, a Teoria proposta pr Dirac foi estendida a todas as partículas e não proíbe a formação de antiátomos e, conseqüentemente, aglomerados deles, dando forma a antiseres, porém as antipartículas são raras, sendo a combinação entre elas, bem improvável.

${ }^{15}$ o conceito de partícula elementar passou por um profundo processo de revisão, culminado no entendimento que estas partículas não são necessariamente imutáveis e indestrutíveis. (Caruso \& Oguri, 1997, p.333)
} 
explicações de outros fenômenos, como o efeito Casimir $^{16}$ e a possível detecção de buracos negros. Além disso, abrindo caminho para a descoberta de novas partículas, através de colisão, em aceleradores de partículas, entre partículas e antipartículas.

\section{7 - As novas interações da natureza}

A descoberta do nêutron, em 1932, por Chadwick, resolvia os problemas enfrentados pelo modelo nuclear constituído de prótons e elétrons, porém, levantava duas questões:

i) com núcleos maiores do que o hidrogênio, como no caso do nitrogênio $(A=14)$, haveria uma concentração de partículas carregadas positivamente em uma região espacial da ordem de $10^{-15} \mathrm{~m}$. Logo, tem-se uma força de repulsão coulombiana considerável entre essas partículas. Então, por que a maioria dos núcleos não explode?

ii) se não há elétrons no núcleo, como explicar a emissão dessas partículas pelos núcleos, no caso de uma emissão beta?

Essas questões esquentaram as investigações sobre o átomo e seu intrigante núcleo. Para responder essas questões, foi necessário introduzir duas novas forças as já existentes: forças gravitacional e eletromagnética.

\footnotetext{
${ }^{16} \mathrm{O}$ efeito Casimir é causado pelo fato de que o espaço vazio é tomado por flutuações do vácuo, pares de partículas virtuais-antipartículas virtuais que continuamente se formam do nada e tornam ao nada um instante depois. $\mathrm{O}$ espaço entre as duas placas restringe o alcance dos comprimento de ondas possíveis para estas partículas virtuais e então poucas delas estão presentes dentro desse espaço. Como resultado, há uma menor densidade de energia entre as duas placas do que no espaço aberto; em essência, há menos partículas entre as placas que do outro lado delas, criando uma diferença de pressão que alguns erroneamente chamam energia negativa mas que realmente não é senão devido a uma maior pressão fora das placas que entre elas, o que as empurra uma contra a outra. (FARINA et al. 2000)
} 


\subsection{1 - Explicando a estabilidade do núcleo}

Verificada que a massa dos constituintes do núcleo eram praticamente as mesmas $\left(\mathrm{m}_{\text {próton }}=938,27 \mathrm{MeV} / \mathrm{c}^{2}\right.$ e $\left.\mathrm{m}_{\text {nêutron }}=939,56 \mathrm{MeV} / \mathrm{c}^{2}\right)$, ainda em 1932, Werner Heisenberg (1901-1976), deu o primeiro passo para solucionar o problema da estabilidade do núcleo.

Heisenberg propôs, que as duas partículas, próton e nêutron, poderiam ser interpretadas como diferentes estados de carga de uma mesma partícula, que denominou de núcleon $^{17}$.

Em 1935, o japonês Hideki Yukawa (1907-1981), previu, que haveria uma força de intensidade maior do que a repulsão eletromagnética, que seria responsável pela estabilidade do núcleo. Fazendo analogia com o fóton, o quantum da interação eletromagnética, previu um quantum para essa interação nuclear. Com um raciocínio simples envolvendo a Relatividade e o Princípio da incerteza, determinou a massa desse quantum, que deveria ser cerca de 300 vezes maior do que a massa do elétron. Para determinar essa massa, Yukawa utilizou o seguiu o seguinte raciocínio:

Quando um sistema qualquer de cargas e correntes elétricas com interação eletromagnética emite um fóton real de energia $E$, a conservação de energia requer que a energia do sistema varie por uma quantidade igual, $\Delta E=E$, a emissão tomando um tempo $\Delta t$ dentro dos limites da relação de incerteza de Heisenberg, $\Delta E \Delta t \geq \hbar / 2$. Se o processo, entretanto, envolver um fóton virtual - o mediador da força eletromagnética - essa relação será violada e $\Delta E \Delta t<\hbar / 2$. Sendo $E$ a energia do fóton virtual (inobservável), $\mathrm{r}_{0} \mathrm{o}$ alcance das forças eletromagnéticas podemos tomar $\Delta t \approx r_{0} / c$ e, finalmente $E=m c^{2}$, para uma partícula relativística de massa m, obteríamos $r_{0}<\hbar / m c$. Logo, a massa das partículas de Yukawa será dada por: $m \approx \frac{\hbar}{r_{0} c}=\frac{1,054 \times 10^{-34}}{1,2 \times 10^{-15} \times 3 \times 10^{8}} \approx 300 m_{e}$. (MARQUES, 2005, p. 180)

${ }^{17}$ Associa-se a essa partícula, um novo número quântico, chamado de ISOSPIN, que descreve partículas com o mesmo spin, porém com massas ligeiramente diferentes. O nome é uma analogia com ISÓTOPOS, que são átomos com o mesmo número atômico e massas um pouco diferente. (TIPLER \& LLEWELLYN, 2001, p.418) 
Tendo assim, uma massa intermediária entre o elétron e o próton, foi chamada de méson. Com uma abordagem mais refinada, Yukawa mostrou, que essa partícula deveria se apresentar em três formas: positivo, negativo e neutro (carga elétrica da mesma intensidade do que a do elétron). No entanto, essas partículas, teriam um curto raio de ação, devido à sua massa, cerca de $10^{-15} \mathrm{~m}$, restringindo-se apenas ao núcleo atômico.

Essa proposta feita por Yukawa era tão concisa que durante muito tempo se procurou a partícula responsável pela interação entre os núcleons. Apesar de algumas críticas; em momento algum, pensaram que essa proposta estivesse errada. Um forte argumento para sustentar a proposta foi a maneira como Yukawa determinou a massa dessa partícula, inspirado na Teoria Quântica de Campos para o Eletromagnetismo (QED)

No final de 1946 e início de 1947, César Lattes (1924-2005), juntamente com Cecil Power (1903-1969) e Giuseppe Occhialini (1907-1993), analisando emulsões fotográficas, encontraram o rastro de uma partícula que concluíram ter massa de 139 $\mathrm{MeV} / \mathrm{c}^{2}$, sendo identificada como a partícula de Yukawa. Identificaram também em algumas emulsões, que essa partícula decaía em uma outra de massa de aproximadamente $106 \mathrm{MeV} / \mathrm{c}^{2}$.

Hoje em dia, a partícula proposta por Yukawa é chamada de méson pi ou píon $(\pi)$, que se apresenta em três versões: $\pi^{+}\left(139,57 \mathrm{MeV} / \mathrm{c}^{2}\right), \pi^{-}\left(139,57 \mathrm{MeV} / \mathrm{c}^{2}\right)$ e $\pi^{0}(134,97$ $\mathrm{MeV} / \mathrm{c}^{2}$ ), sendo a pequena diferença de massa, atribuída possivelmente à carga elétrica.

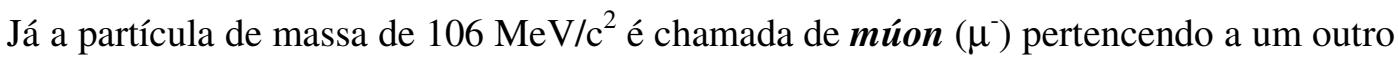
grupo de partículas, denominadas léptons, sendo considerado uma espécie de primo mais pesado do elétron, que são diferentes dos mésons. (Bassalo, 2000)

Com o desenvolvimento dos aceleradores de partículas, com energias necessárias para a produção de novas partículas, em 1948, o píon foi detectado por Lattes e Gardner no acelerador de Berkeley.

Essas detecções corroboraram para validar a teoria proposta por Yukawa, explicando a força entre os núcleons, sendo chamada de força forte. O "mecanismo" de 
funcionamento dela, pode ser entendido da seguinte maneira: um próton ao emitir um píon positivo, se "transforma" em nêutron, caso esse píon positivo seja "absorvido" por um outro nêutron, ele se torna um próton. Já o nêutron quando emite um píon negativo, se torna um próton, um outro próton ao "absorver" esse píon, se torna nêutron. No caso da interação próton-próton e nêutron-nêutron, o píon trocado seria o neutro (Menezes, 2005. p.194). Posteriormente, foi provado, que a intensidade da força forte não depende da carga das partículas, ou seja, ela é a mesma, tanto para a interação próton-próton, nêutron-nêutron, quanto para próton-nêutron. Justificando assim, o tratamento dado por Heisenberg a essas partículas, propondo serem estados diferentes da mesma partícula, os núcleons.

As investigações e estudos sobre o núcleo atômico revelaram diferentes forças, da já conhecida eletromagnética. Essas novas forças teriam sua "existência" restrita ao núcleo, por isso não haviam sido ainda detectadas. A força nuclear seria então a responsável pela estabilidade do núcleo, permitindo que houvesse uma atração de intensidade maior do que a repulsão coulombiana entre os prótons.

\subsection{2 - O problema do decaimento beta}

Na década de 20, um problema assolava a comunidade científica. Ninguém sabia explicar porquê na observação do decaimento beta, o elétron emitido pelo núcleo assumia valores de energias que variavam continuamente de zero até um valor máximo, em contraste ao valor esperado, que deveria ser bem determinado ${ }^{18}$. Isso porque, todos os valores da equação que descrevem o processo eram conhecidos. Além disso, se o núcleo inicial (mãe) estivesse em repouso, esperava-se que o núcleo final (filho) e o elétron tivessem deslocamento na mesma direção e sentidos opostos, para conservar o momento linear do sistema. Mas nada disso era observado nas experiências.

Esses problemas levaram Bohr, em 1932, a questionar a validade dos teoremas de conservação, abalando um dos principais pilares da Física. Em um ato de "desespero",

\footnotetext{
${ }^{18}$ No decaimento beta de um núcleo A, inicialmente em repouso, em um núcleo B mais um elétron, podese determinar a energia do elétron através da equação: $\quad E_{e}=\left(\frac{m_{A}^{2}-m_{B}^{2}+m_{e}^{2}}{2 m_{A}}\right) c^{2}$ (GUZZO \&
}

NATALE, 2005, p.194) 
Bohr sugeriu que as conservações de energia e momento linear, não seriam válidas para o mundo microscópico.

Em 1930, Pauli sugeriu (para tentar resolver esses problemas), que no decaimento beta, uma outra partícula, sem carga e com massa praticamente nula, seria emitida junto com o elétron, descrevendo o decaimento beta de um núcleo da seguinte maneira: $A \rightarrow$ $B+e^{-}+x$. (Guzzo \& Natale, 2005, p.195). Devido às suas propriedades, essa partícula não seria detectada e seria responsável por carregar a energia que faltava ao elétron, não sendo necessário alterar os teoremas da conservação.

Enrico Fermi (1901-1954), em 1931, tomou conhecimento da proposta de Pauli e batizou a partícula de neutrino (pequeno neutro, em italiano). Com a descoberta do nêutron, em 1932, por Chadwick, Fermi pôde formular uma teoria fundamentada para esse processo, mostrando que no nível mais fundamental, ele ocorria com o nêutron. $\mathrm{O}$ nêutron "transforma-se" (decai) em um próton com a emissão de um elétron e um neutrino ${ }^{19}$. Além disso, sua teoria era capaz de descrever o espectro de energia do decaimento beta, caso o neutrino tivesse massa ou não. (Guzzo \& Natale, 2005)

O neutrino só foi detectado em 1956, em uma experiência onde ocorriam colisões de neutrinos oriundos de um reator nuclear com prótons de um cintilador líquido, por Clyde Lorrain Cowan (1919-1974) e Frederick Reines (198-1998), dois cientistas que haviam trabalhado em Los Alamos na construção da primeira bomba atômica.

Enquanto as experiências eram montadas, na tentativa de detectar o neutrino, modificações foram feitas na Teoria de Fermi, por Tsung Dao Lee (1926- ) e Chen Ning Yang (1922- ), mostrando que o decaimento beta a paridade não seria conservada, ou seja, o decaimento beta só poderia emitir antineutrinos de mão direita.

A teoria de Fermi, também propunha, que o processo do decaimento beta era devido à manifestação de um campo de força tão fundamental quanto os demais já conhecidos (Gravitação e o Eletromagnetismo). Essa interação é hoje conhecida por interação fraca.

\footnotetext{
${ }^{19}$ A equação para descrever o decaimento beta do nêutron é a seguinte: $n \rightarrow p+e^{-}+\nabla_{e}$ (BASSALO, 2002, p.85)
} 
A diferença de energia, teórica e experimental, da emissão beta, levou Pauli a formular a existência de uma partícula hipotética, sem massa (ou quase nenhuma) e sem carga, por isso de difícil detecção. Aqui, inicia-se uma maneira diferente de pensar na natureza e na elaboração de uma teoria compatível com ela: primeiro, a formulação de uma partícula; anos depois a sua detecção (acredita-se, que o mesmo ocorrerá no caso do gráviton e dos Bósons de Higgs, que são partículas previstas na teoria, mas ainda não foram detectadas).

Uma outra força (Força Fraca) manifestada através dos estudos sobre o núcleo atômico, foi a responsável pela "transformação" de um nêutron em um próton, denominado de decaimento beta. Nesse processo, o nêutron decai em próton, um elétron e um antineutrino do elétron. Revelando dessa maneira, o mecanismo que levava os físicos a pensarem que existiam elétrons no núcleo.

\subsection{3 - A descoberta de novas partículas}

Com a construção de novos e mais potentes aceleradores de partículas, os raios cósmicos foram "deixados de lado", pois apesar de fornecerem feixes de altíssimas energias, não podiam ser controlados, como no caso dos aceleradores.

Em 1952, conseguiu-se acelerar elétrons com energia da ordem de $1 \mathrm{GeV}$, produzindo partículas $\Lambda$, que já haviam sido detectadas nos raios cósmicos. Naquela época havia-se demonstrado que além de píons e múons, os raios cósmicos continham partículas mais pesadas que os núcleons. Essas partículas foram chamadas de híperons, tendo como a característica, o fato de em seu decaimento final sempre obter-se um próton ou nêutron ${ }^{20}$.

Contudo, o decaimento da partícula $\Lambda$ apresentava certa "incoerência". Ela podia ser produzida facilmente, porém seu decaimento era lento. Isso violava alguns princípios da Mecânica Quântica, que indicavam que se uma partícula é formada facilmente, ela também se desintegra facilmente. A explicação para esse fenômeno veio com Pais e Nishijima, mostrando que o processo de produção e decaimento são

\footnotetext{
${ }^{20}$ Exemplos de decaimento dos híperons: $\Lambda \rightarrow \mathrm{p}+\pi^{-} ; \Sigma^{+} \rightarrow \mathrm{p}+\pi^{0}$
} 
processos distintos. Enquanto a produção depende da força forte, o decaimento depende da força fraca.

Em 1953, foi proposto por Murray Gell-Mann (1929- ), Nakaoro e Nishijima, um novo número quântico associado a esse processo, denominado de estranheza. Atribuindo valores $0, \pm 1, \pm 2, \pm 3$, para as partículas, sendo que a soma da estranheza não se altera na interação forte, somente na fraca. (Tipler \& Llewellyn, 2001)

Devido aos problemas encontrados nos modelos que procuravam explicar a detecção de centenas de partículas, através de poucas, consideradas elementares. Murray Gell-Mann e George Zweig (1937- ), em 1964, propuseram um modelo de representação fundamental para as partículas elementares. Esse modelo era baseado em um tripleto de partículas, denominados quarks, que se apresentariam em três sabores: up (u), down (d) e strange (s). Assim, bárions, como o próton e o nêutron, são descritos por três quarks (uud; udd); já os mésons, como o píon, por um quark e um antiquark. (Bassalo, 2000)

Porém, uma das grandes dificuldades de se considerar esse tripleto fundamental era a sua carga fracionária $(+2 / 3 e ;-1 / 3 e)$. Contudo, em 1969, “com experiências com espalhamento de elétrons por prótons, pôde observa que eles eram constituídos por partes, mostrando que essas partes deveriam ter carga fracionária" (Caruso \& Oguri, 1997, p.332). Sendo identificados como os quarks de Gell-Mann e Zweig.

Com a aceitação desse tripleto, foi possível prever uma série de novas partículas que ainda não haviam sido observadas, como o caso do $\Delta^{++}$(uuu) e $\Delta^{-}$(ddd), chamadas de estados ressonantes. Porém, quarks têm spin fracionário (1/2), sendo considerados férmions. Logo, devem obedecer o princípio da exclusão de Pauli. Para resolver esse problema, foi proposto por Oscar W. Greenberg , M. Y. Han e Y. Nambu (1921- ), em 1965, um novo número quântico, denominado $\operatorname{cor}^{21}$. Assim, os quarks deveriam se apresentar no interior das partículas em três cores distintas: azul (blue), verde (green) e vermelho (red). Tornando os bárions, partículas brancas, já que propriedade não se manifestava no exterior delas. Seguindo essa lógica, os antiquarks se apresentariam com

\footnotetext{
${ }^{21}$ O termo cor utiliza-se as cores do espectro de luz visível de forma metafórica e não "real”. Ela é somente mais uma propriedade dos quarks, mais um número quântico, como o spin e a carga elétrica.
} 
as anticores: antiazul (amarelo), antiverde (magenta) e o antivermelho (ciano). "Estava assim, salvo o princípio da exclusão de Pauli.” (Caruso \& Oguri, 1997, p.332)

Com o novo número quântico trazido com os quarks - a carga cor- foi possível formular uma teoria, análoga com a Eletrodinâmica Quântica (QED). Essa nova teoria, que descrevia a interação entre os quarks, ficou conhecida como Cromodinâmica Quântica (QCD). Nela, a interação entre os quarks seria conseqüência da troca, entre eles, de glúons, que seriam responsáveis pela carga cor dos quarks. Esses glúons, seriam no total de oito, não possuindo carga elétrica e nem massa e, por serem agentes da interação, teriam spin 1.

Assim, para que os quarks se mantivessem unidos para formar os hádrons, era necessário a troca de glúons entre eles, ou seja, os quarks constantemente trocariam suas cores através da "emissão" e "absorção" de glúons, que também são coloridos.

Outros quarks foram propostos e detectados nos anos seguintes, em 1977, o quark charm (c). Depois foi a vez do bottom (b) e, em seguida, já em 1995, o top (t), tendo a contribuição de pesquisadores do centro Brasileiro de Pesquisas Físicas (CBPF).

\section{8 - Enfim, o modelo padrão.}

A partir de toda pesquisa envolvendo a busca das partículas, e a maneira como elas interagem, foi possível, a partir do final da década de 80, desenvolver uma descrição global dessa área da Física, através do denominado Modelo Padrão.

Esse modelo descreve a matéria, através dos quarks e léptons, que são férmions e, os bósons, que são os agentes das interações forte, fraca e eletromagnética.

$\mathrm{Na}$ descrição da interação forte, são necessários os quarks (up, down, strange, charm, bottom e top) e os glúons, organizados na Cromodinâmica Quântica. A interação 
entre os quarks se dá pela troca de glúons que, essencialmente, modifica a $\operatorname{cor}^{22}$ dos quarks. Desta forma, os glúons são sensíveis somente em relação à carga cor e, como eles próprios são portadores dessa carga, podem interagir entre si; fenômeno que não ocorre em nenhum outro tipo de interação.

$\mathrm{Na}$ teoria da interação fraca, aparecem outros tipos de bósons mensageiros, os bósons $\mathrm{W}^{+}, \mathrm{W}^{-}$e $\mathrm{Z}^{0}$ (detectados em 1983 no CERN). Essa interação é a responsável pela transmutação nuclear, tendo sua ação restrita a dimensão subnucleares $\left(10^{-18} \mathrm{~m}\right)$, ou seja, atua sorrateiramente, modificando as partículas. Esse seu curto raio de ação, faz com que seus mensageiros sejam muito massivos, em torno de $80 \mathrm{GeV} / \mathrm{c}^{2}$. (Salan; Heisenberg; Dirac, 1993)

A Eletrodinâmica Quântica descreve a interação eletromagnética; sendo o fóton, o seu agente mensageiro. Esse bóson, ao contrário dos demais, não possui nenhum tipo de carga ou massa, sendo sensível somente à carga elétrica. Desta forma, ele está relacionado a todo tipo de partícula que tenha carga elétrica.

As interações eletromagnéticas e a fraca, atualmente, são descritas por um modelo que as unificou num único esquema, as interações eletrofraca. Os bósons de gauge $\mathrm{W}^{+}$, $\mathrm{W}^{-}$e $\mathrm{Z}^{0}$ e o fóton, seriam manifestações de uma mesma entidade básica transmissora das interações. Essa unificação é baseada em uma teoria de gauge ${ }^{23}$, através de um mecanismo chamado quebra espontânea de simetria. Explicando porque os bósons $\mathrm{W}^{+}$, $\mathrm{W}^{-}$e $\mathrm{Z}^{0}$ possuem massa e o fóton não. (Salan; Heisenberg; Dirac, 1993)

A teoria que descreve cada uma das interações, tem uma estrutura matemática baseada em trocas de campos com uma forma de simetria muito peculiar, a simetria por transformações de calibre ou simetria de gauge, garantindo consistência matemática à teoria.

Os férmions podem ser separados em dois grupos: os léptons, no total de seis e os quarks também na mesma quantidade. Essas partículas estão separadas em gerações

\footnotetext{
${ }^{22}$ A idéia de cor utilizada na Cromodinâmica Quântica não tem nada haver com o espectro de luz e sim, uma denotação de um outro tipo de carga, diferente da carga elétrica, para denominar um novo número quântico. Assim, cada quark pode assumir três cores distintas: red (r), green (g) e blue (b).

${ }^{23}$ Essa teoria está fundamentada nas forças de gauge, que são mediadas por bósons de spin 1.
} 
(dupletos), indicando a sua ordem de descoberta, sendo importantes para a descrição da matéria a nossa volta, somente os férmions da primeira geração.

Quadro dos férmions

\begin{tabular}{|c|c|c|c|}
\hline & $1^{a}$ Geração & $2^{\mathrm{a}}$ Geração & $3^{a}$ Geração \\
\hline Quarks & $\left(\begin{array}{c}\text { up } \\
\text { down }\end{array}\right)$ & $\left(\begin{array}{c}\text { strange } \\
\text { charm }\end{array}\right)$ & $\left(\begin{array}{c}\text { botton } \\
\text { top }\end{array}\right)$ \\
\hline Léptons & $\left.\begin{array}{l}\mathrm{e}^{-} \\
\mathrm{v}_{\mathrm{e}}\end{array}\right\}$ & {$\left[\begin{array}{l}\mu^{-} \\
v_{\mu}\end{array}\right]$} & $\left(\begin{array}{c}\tau^{-} \\
v_{\tau}\end{array}\right)$ \\
\hline
\end{tabular}

Quadro de Bósons

\begin{tabular}{l|c}
\hline \multicolumn{1}{c|}{ Interação } & Bóson \\
\hline Eletromagnética & Fóton \\
\hline Fraca & $\mathrm{W}^{+} ; \mathrm{W}^{-} ; \mathrm{Z}^{0}$ \\
\hline Forte & Glúons \\
\hline
\end{tabular}




\section{CAPÍTULO 3}

\section{O CURSO}

\section{1 - Introdução}

Há aproximadamente duas décadas, é notória a discussão sobre a inserção da Física Moderna e Contemporânea no Ensino Médio e, existe um consenso entre as pesquisas em ensino de Física de que isso é possível, conforme visto no primeiro capítulo. Porém, poucas são as propostas que levam, de fato, essa área de conhecimento científico à sala de aula, e ainda, a maioria das propostas não têm um retorno de suas aplicações que contribuam para a melhoria das futuras propostas. Refletindo sobre esse quadro, foi elaborada uma sequiência didática sobre Física de Partículas Elementares, que introduz os principais conceitos dessa área à alunos do Ensino Médio, fazendo com que eles tenham contato com essa área da Física durante o processo de formação básica.

\section{2 - $O$ recorte dos saberes}

O conhecimento passa por uma série de processos de transformações e adaptações, até chegar à sala de aula, sendo necessário uma reestruturação do conhecimento científico, para que este possa estar presente na escola (sssa discussão será feita no capítulo seguinte). Porém, a reestruturação do conhecimento científico para a sala de aula, conforme a Transposição Didática prevê, não pode torná-lo muito distante do original. Por que desta forma, ele não será reconhecido pela comunidade que produziu o saber de referência, de onde se inicia o processo de transformação do saber. Por outro lado, ele também não pode estar muito perto deste saber de referência, pois se tornaria um saber muito avançado e sem muito significado para os alunos ${ }^{24}$.

Assim, não se pode esperar que os "glúons" e "quarks", que serão tratados nessa proposta, sejam exatamente iguais aos tratados pelo conhecimento científico. É claro

\footnotetext{
${ }^{24}$ Esses aspectos do saber serão explorados no capítulo seguinte.
} 
que terão certas características conservadas, mas sofrerão algumas adaptações, para que possam tornar mais inteligíveis aos jovens e ao mesmo tempo serem reconhecidos pelos físicos que "produzem" esse conhecimento nos laboratórios, sendo legitimado pela comunidade científica.

Desta forma, foi necessário definir o que poderia ser levado para sala de aula sobre a Física de Partículas Elementares, já que é uma área que possui muitos conceitos importantes, com seus tratamentos avançados de matemática, fazendo com que estejam interligados, formando uma área da Física bem estruturada.

Ciente disso, o foco foi feito sobre os objetivos principais do curso, que são: mostrar aos jovens uma maneira mais detalhada da constituição da matéria e quais as consequiências que essa "nova" forma de observar a matéria traria, não só para o conhecimento Físico, mas também para uma visão de mundo. Por isso, o material confeccionado buscou trabalhar os aspectos mais atuais da descrição da matéria, chegando ao final, na descrição do Modelo Padrão das partículas elementares e suas interações.

Teve-se também o cuidado, de adaptar um conhecimento estruturado em uma linguagem matemática sofisticada em uma linguagem puramente conceitual, sem perder o seu significado enquanto conhecimento Físico e ainda não cometendo o erro de montar um curso meramente informativo.

Levando em conta os aspectos anteriores e os recursos disponíveis, como as pesquisas em ensino de Física, os materiais de divulgação desse tópico, os livros e propostas didáticas que abordam essa área, conseguimos montar uma primeira versão do curso, que posteriormente foi modificado, tornando-se a seqüência atual. Procuramos então, trabalhar conceitos essenciais da Física de Partículas, como: partículas elementares, antipartículas, mensageiros das interações, chegando à descrição do Modelo Padrão para a estrutura da matéria, como já foi comentado anteriormente.

Tivemos ainda, uma grande preocupação, em não focar as discussões de conteúdos formais da Ciência, na elaboração da seqüência, mas em estender as discussões para além dessa dimensão, tratando também questões sobre a natureza 
Ciência. Assim, contemplamos os aspectos históricos, filosóficos e epistemológicos, procurando tratar assuntos como a validação de teorias (teoria da força forte e fraca), o contexto que leva a descoberta de novas teorias e o papel dos modelos na Ciência.

\section{3 - Algumas propostas}

Assim como a Mecânica Quântica e a Relatividade, a Física de Partículas Elementares é um tema pouco pesquisado em sala de aula. É comum, atualmente, encontrarmos propostas, que procuram tratar a Mecânica Quântica e a Relatividade no E. M. no Brasil. Porém, poucos trabalhos bem estruturados e validados contribuem para um retorno metodológico (uma vez que não há um consenso de qual é a melhor metodologia a ser aplicada com esses conteúdos) de suas bem sucedidas aplicações (Brockington, 2005; Rodrigues, 2001; Fagundes, 1997). De fato, poucos têm acrescentado para a melhoria e a atualização do currículo de Física no E.M.

Com a Física de Partículas Elementares isso não é diferente. As propostas no Brasil são muito mais raras do que em outros países, onde elas também são poucas. O que se encontra normalmente são alguns tópicos isolados que tentam trabalhar um pouco da Física de Partículas Elementares. Porém não são cursos "completos", que façam uma abordagem dos conceitos principais. Para agravar mais esse quadro são raras as propostas, que têm uma preocupação mais profunda com o ensino ou, que, foram aplicadas proporcionando frutos para a pesquisa em ensino de Física. Ou seja: é "reduzido o número de trabalhos publicados que encaram a problemática sob a ótica do ensino e, mais ainda, os que buscam colocar, em sala de aula, propostas de atualização.” (OSTERMANN \& MOREIRA, 2000, p. 5)

A maioria dos trabalhos publicados em revistas de ensino de Física concentram-se na apresentação de alguns tópicos de Física de Partículas Elementares destinados à para professores ou para alunos que estão iniciando os estudos universitários. Além disso, grande parte desses trabalhos são feitos em outros países, como Inglaterra e Estados Unidos (Allday, 1997; Barlow, 1992; Farmelo, 1992, Jones, 1992; Lederman, 1982, Ryder, 1992, 1976). Isso mostra, como são escassos os trabalhos voltados para o ensino 
de Física de Partículas, que vão além da vertente de somente apresentar o conteúdo. Também constatamos que não se tem quase nenhum material sobre esse assunto produzido no Brasil ${ }^{25}$.

Como a quantidade de material dessa área, produzido no Brasil, voltada ao ensino é pequena, muitos físicos e pesquisadores da área de ensino têm buscado produzir materiais que possam servir de suportes para professores do E.M. Desta forma, procurase melhorar o conhecimento dos professores sobre a Física de Partículas Elementares e assim inserí-la no contexto escolar. (Moreira, 2004; Ostermann, 2000; Alves et al., 2000; Caruso et al., 2005; Marinelli, 1989).

Mais raras ainda são as propostas que, de fato, levaram a Física de Partículas Elementares para o E.M., e que foram avaliadas com o intuito de produzir dados para o desenvolvimento de pesquisas com fins didáticos. Nesse sentido, destacamos três trabalhos: Ostermann \& Moreira (2001), Swinbank (1992) e Project Harvard (1987). Apenas o primeiro trabalho foi aplicado e trouxe alguns resultados após sua aplicação no E.M. Os outros dois, são propostas que não produziram resultados de suas aplicações.

O trabalho desenvolvido por Ostermann \& Moreira (2001), mostra a aplicação de um curso de Física de Partículas Elementares por alunos da licenciatura em Física que fizeram estágio da disciplina de "práticas de ensino de Física" na UFRGS. Esse trabalho resultou em um texto ${ }^{26}$ para professores do E. M. sobre o assunto (Ostermann, 2001) e mostrou, que para ocorrer essa inserção, devemos preparar os professores, com cursos de formação continuada. No caso dos alunos da licenciatura, foram ministradas aulas durante um mês pela professora da disciplina, que é a autora do trabalho. Essas aulas baseiam-se no texto produzido. Porém, antes disso, a docente da disciplina, sentiu a necessidade de preparar um texto para os professores (estagiários), sendo posteriormente adaptados para os alunos, resultando no texto citado anteriormente.

\footnotetext{
${ }^{25}$ Em um trabalho recente, apresentado no V ENPEC, em Bauru, por Siqueira e Pietrocola, pode-se notar que existe um movimento de tentar modificar esse quadro.

${ }^{26} \mathrm{O}$ texto de apoio ao professor, possui 69 páginas e inclui um breve histórico do desenvolvimento do conceito de átomo, as descobertas do início do século XX, leis de conservação, interações fundamentais e o modelo padrão atual. Há também uma tabela e duas figuras que resumem as partículas elementares e as interações fundamentais, alguns exercícios e atividades. (OSTERMANN \& MOREIRA, 2001, p.141)
} 
As aulas ministradas pelos estagiários destinaram-se a 126 alunos de 6 turmas da $1^{\mathrm{a}}, 2^{\mathrm{a}}$ e $3^{\mathrm{a}}$ série do E.M. Somente uma turma da $3^{\mathrm{a}}$ série pertencia a uma escola particular.

Ostermann \& Moreira (2001) apontaram ainda nesse trabalho, resultados promissores, indicando que é possível ensinar a Física de Partículas Elementares para alunos do E.M., e mostrando que não tiveram nenhuma dificuldade de natureza cognitiva para aprender o conteúdo. Além disso, se apresentaram dificuldades de aprendizagem, elas não foram muito diferentes da Física Clássica, demonstrando também, que esse tópico desperta a curiosidade nos alunos.

Quanto à metodologia, o trabalho mostrou que o uso de analogias foi bem sucedido e que, quando possível, deve-se fazer um vínculo com os conteúdos já contemplados.

Os outros trabalhos citados anteriormente, não relatam a aplicação em sala de aula, contudo mostram uma preocupação com o ensino de Física de Partículas Elementares. Esses trabalhos serviram de inspiração para a confecção de nossa seqüência didática e também para a elaboração de textos sobre o assunto.

Swinbank (1992) apresenta em seu artigo, um curso sobre as Partículas Elementares e as Interações entre elas. Essa seqüência didática foi aplicada no curso de Física post-GCSE, na Inglaterra. Contudo, ele não aponta resultados de aplicações do curso, nem elucida o tipo de abordagem/metodologia utilizada.

A unidade suplementar A, do Project Harvard é destinado a Física de Partículas Elementares. Esse material, que já possui uma sequiência estabelecida, tem como objetivo, fazer com que os estudantes vivenciem o trabalho dos cientistas na detecção das partículas, determinando as características destas através do rastro (trajetória) deixado nas câmaras de bolhas ou nuvens. Para isso, trabalha-se inicialmente, todos os conceitos necessários para que a atividade de determinação do tipo de partícula seja proposta posteriormente. Essa proposta serve como uma boa referência para os professores que buscam um conhecimento sobre as Partículas Elementares, e como possui uma versão em português, é de fácil acesso aos professores. 
Depois de analisar diferentes propostas sobre a Física de Partículas Elementares e alguns livros didáticos, decidimos abandoná-las e montar uma seqüência própria inspirada em alguns trabalhos que atendiam aos nossos anseios. Assim, fomos em busca de um ponto de partida, um tema que pudesse servir de ponto de partida para o curso. Orientados pela sensibilidade trazida com a experiência de sala de aula, optamos em começar com um assunto que fosse mais próximo do aluno, para que assim, ele tivesse motivação adicional para estudar esse conteúdo.

Assim, decidimos partir de uma fenomenologia mais próxima possível da vivida pelo aluno como a radiografia e os Raios-X, acreditando que com isso, pudéssemos despertar maior interesse dos alunos em conhecer o conteúdo que queríamos tratar.

Porém, a falta de um consenso nas pesquisas em ensino, não indicando qual a melhor abordagem metodológica, causava dúvidas sobre qual seria a melhor maneira de inserir o tópico. Mostrando ainda, a falta de um norteador metodológico para a inserção da FMC.

[...] pode-se verificar que, além de ser um tanto escassa a literatura a respeito de questões metodológicas sobre o ensino de FMC nas escolas, há várias divergências a respeito de que caminho deve ser tomado. (OSTERMANN \& MOREIRA, 2000, p.9)

Contudo, três vertentes apontadas por Ostermann \& Moreira (2000), indicando a exploração dos limites clássicos; a não utilização de referências aos modelos clássicos e a escolha de tópicos essenciais poderiam ser utilizadas como possíveis caminhos a serem seguidos.

Tendo como objetivo levar uma nova visão da natureza através do conhecimento mais profundo da estrutura da matéria, nos apoiado nos estudos de Astolfi \& Develay (2006, p.51) que mostram que "o valor intrínseco de um conteúdo nunca é suficiente para fundar sua inserção didática, mas esta depende também de um projeto educativo que conduz a uma seleção entre as várias possibilidades." Chegamos assim, a uma abordagem que segue o uso de modelos clássicos, na linha de um trabalho feito por Arons (1990). Esse autor defende a idéia, de que poucos conceitos de FMC devam ser ensinados no E.M., tendo como objetivo levar alguma percepção aos alunos sobre esses 
conceitos. E ainda, que a Física Clássica deva servir de sustentação para a abordagem dos tópicos da FMC, ou seja, que se busque na Física Clássica somente os elementos essenciais para compreensão da FMC.

A partir disso, foram escolhidos os tópicos que seriam transpostos para a sala de aula, e o início do curso. Assim a seqüência foi elaborada a partir dos seguintes temas: radiações, modelos atômicos, força forte, modelo dos quarks e glúons, aceleradores e detectores de partículas, neutrino e a força fraca, matéria e antimatéria, as novas leis de conservação, quantização do campo, diagramas de Feynman, famílias das partículas e o modelo padrão.

Com essa escolha conseguimos determinar, que os tópicos (campo eletromagnético, radiação eletromagnética, força elétrica e magnética e carga elétrica) da Física Clássica eram imprescindíveis para o curso. Desta forma, pretendeu-se criar condições favoráveis para inserir a Física de Partículas Elementares no E.M.

Optamos então, por mostrar os aspectos fundamentais dos saberes clássicos citados anteriormente, o comportamento de seus modelos, bem como o processo de criação científica, já no início do curso, acreditando que, desta forma, os alunos pudessem notar a diferença entre os modelos clássicos presentes em sala de aula e os modelos da FMC que estavam sendo inseridos.

Com uma abordagem fenomenológica-conceitual ${ }^{27}$ para guiar o nosso trabalho, conseguimos abrir um maior número de opções e adequar melhor nossa abordagem pedagógica ao perfil dos alunos e ao andamento do curso. Com isso recorremos também ao uso da História da Ciência e outros recursos que nos auxiliaram na construção dos conceitos da Física de Partículas Elementares, como, por exemplo, animações e simulações.

\footnotetext{
${ }^{27}$ Fenomenológico por propiciar a criação de uma nova percepção, e conceitual na medida em que os fenômenos escolhidos devem ser suficientemente simples (elementares) e dirigidos de forma a que a essência semântica dos (primeiros) conceitos envolvidos fique evidente (GRECA \& MOREIRA, 2001, p. 446)
} 


\section{4 - A seqüência didática}

Depois de definirmos a parte da Física de Partículas a ser levada para sala de aula, com os principais conceitos para alcançarmos o objetivo do curso, nos deparamos com mais um uma questão a ser respondida: Qual seria a melhor seqüência a ser montada?

Iniciamos a proposta com um projeto piloto, que tinha sua seqüência baseada na extrapolação do caráter clássico para introduzirmos o caráter quântico, ou seja, usando os limites do campo eletromagnético clássico (mundo macroscópico) passaríamos para o quântico (mundo microscópico). Desta forma, começaríamos a trabalhar as partículas, inicialmente tratando da interação devido à carga elétrica, como prótons e elétrons e o mediador dela, no caso, o fóton. A partir desse ponto, levantaríamos alguns problemas que instigariam os alunos a buscar um conhecimento maior, desenvolvendo o curso, com o intuito de "amarrar" os conceitos. A seqüência piloto adotada foi a seguinte:

\begin{tabular}{|c|c|c|c|}
\hline Tema & Conteúdo & Objetivo & $\begin{array}{l}\text { Atividades } \\
\end{array}$ \\
\hline $\begin{array}{l}\text { Interação } \\
\text { Eletromagnética }\end{array}$ & $\begin{array}{l}\text { - Revisão do modelo } \\
\text { de campo } \\
\text { eletromagnético } \\
\text { clássico. } \\
\text { - Apresentação e } \\
\text { discussão do } \\
\text { modelo de campo } \\
\text { eletromagnético } \\
\text { quântico. }\end{array}$ & $\begin{array}{l}\text { Discutir a } r \\
\text { concepção do campo } \\
\text { eletromagnético } \\
\text { partir do a campo } \\
\text { elétrico clássico. }\end{array}$ & $\begin{array}{l}\text { Experiência de atração } \\
\text { da bolinha por um } \\
\text { corpo carregado; } \\
\text { atração do metal pelo } \\
\text { ímã e pulverização da } \\
\text { água (troca de fótons), } \\
\text { questões sobre a } \\
\text { interação } \\
\text { eletromagnética, texto } \\
\text { sobre interação } \\
\text { eletromagnética, uso } \\
\text { de figuras no } \\
\text { datashow. }\end{array}$ \\
\hline $\begin{array}{l}\text { Algumas propriedades } \\
\text { das partículas: carga e } \\
\text { massa / Interação } \\
\text { Gravitacional }\end{array}$ & 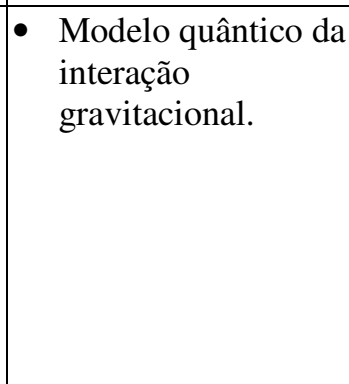 & 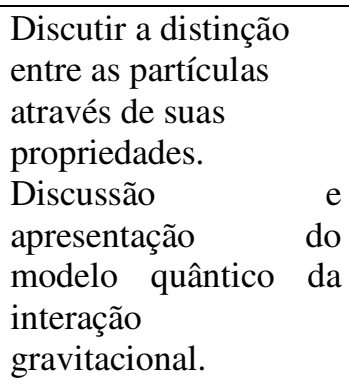 & $\begin{array}{l}\text { Questões sobre a } \\
\text { comparação entre as } \\
\text { duas interações já } \\
\text { estudadas, texto sobre } \\
\text { algumas propriedades } \\
\text { das partículas, uso de } \\
\text { figuras mostrando a } \\
\text { interação gravitacional } \\
\text { no datashow. }\end{array}$ \\
\hline $\begin{array}{l}\text { Ordem de grandeza e } \\
\text { apresentação do } \\
\text { problema do núcleo }\end{array}$ & $\begin{array}{l}\text { - Por que o núcleo } \\
\text { não explode devido } \\
\text { a repulsão entre os } \\
\text { prótons? }\end{array}$ & $\begin{array}{l}\text { Discutir a ordem de } \\
\text { grandeza envolvida na } \\
\text { Física de Partículas } \\
\text { (tamanho, massa, } \\
\text { energia). } \\
\text { Colocar o problema do }\end{array}$ & $\begin{array}{l}\text { Visualizando "o muito } \\
\text { pequeno" (cortando } \\
\text { papel para chegar ao } \\
\text { tamanho do próton, } \\
\text { tamanhos dos objetos } \\
\text { estudados em Física }\end{array}$ \\
\hline
\end{tabular}




\begin{tabular}{|c|c|c|c|}
\hline & & $\begin{array}{l}\text { núcleo e discuti-lo, } \\
\text { retomando a interação } \\
\text { eletromagnética, } \\
\text { através da repulsão. } \\
\end{array}$ & de Partículas). \\
\hline $\begin{array}{l}\text { Interação Forte } \\
\text { Modelo da interação } \\
\text { forte }\end{array}$ & 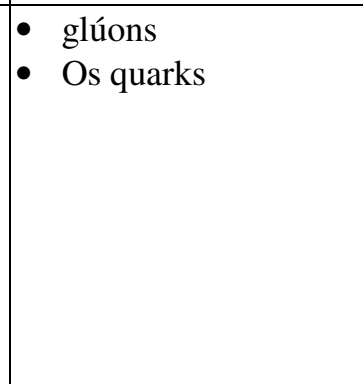 & \begin{tabular}{|l|} 
Discutir a maneira \\
como as partículas do \\
núcleo permanecem \\
unidas. \\
Apresentar o Modelo \\
da interação forte e o \\
modelo dos quarks \\
que constituem as \\
partículas do núcleo. \\
\end{tabular} & $\begin{array}{l}\text { Mostrar o site que tem } \\
\text { a construção de } \\
\text { partículas e átomos a } \\
\text { partir dos quarks e } \\
\text { léptons - } \\
\text { www.pbs.org/wgbh/as } \\
\text { o/tryit/atom (atom } \\
\text { build - Mattuck). }\end{array}$ \\
\hline $\begin{array}{l}\text { Características dos } \\
\text { quarks (up, down, } \\
\text { strange, charm, botton, } \\
\text { top) }\end{array}$ & $\begin{array}{l}\text { - A carga cor } \\
\text { - Troca de glúons } \\
\text { entre os quarks no } \\
\text { interior das } \\
\text { partículas } \\
\text { (partículas brancas) }\end{array}$ & $\begin{array}{l}\text { Discutir a carga } \\
\text { elétrica, carga de cor, } \\
\text { massa, spin. } \\
\text { Troca de glúons entre } \\
\text { os quarks no interior } \\
\text { das partículas } \\
\text { (partículas brancas) }\end{array}$ & $\begin{array}{l}\text { Atividades: pião } \\
\text { pintado com as cores } \\
\text { dos quarks, girando } \\
\text { para mostrar as } \\
\text { partículas brancas. }\end{array}$ \\
\hline $\begin{array}{l}\text { Antiquarks e } \\
\text { antipartículas. }\end{array}$ & $\begin{array}{l}\text { - } \\
\text { Aniquilação: } \\
\text { partícula x } \\
\text { antipartículas } \\
\text { - } \text { Matéria x } \\
\text { antimatéria }\end{array}$ & $\begin{array}{l}\text { Mostrar e discutir a } \\
\text { existência de } \\
\text { Antiquarks e } \\
\text { antipartículas. } \\
\text { Discutir o processo de } \\
\text { aniquilação e } \\
\text { produção: partícula x } \\
\text { antipartículas - } \\
\text { matéria x antimatéria. } \\
\text { Mostrar outras } \\
\text { partículas formadas } \\
\text { pelos quarks }\end{array}$ & $\begin{array}{l}\text { Filme: Jornada nas } \\
\text { Estrelas }\end{array}$ \\
\hline Interação Fraca & $\begin{array}{ll}\text { - } & \text { Instabilidade do } \\
\text { nêutron fora do } \\
\text { núcleo - } \\
\text { decaimento } \beta \\
\text { - } \\
\text { Neutrino: sua } \\
\text { descoberta e } \\
\text { importância na } \\
\text { energia do Sol e das } \\
\text { estrelas. } \\
\text { - Um pouco de Física } \\
\text { Nuclear: } \\
\text { decaimento } \alpha, \\
\text { fissão e fusão } \\
\text { nuclear. } \\
\text { - Datação com } \\
\text { Carbono } 14 .\end{array}$ & $\begin{array}{l}\text { Discutir o papel } \\
\text { fundamental } \\
\text { desempenhado pelo } \\
\text { nêutron na } \\
\text { estabilidade do núcleo } \\
\text { e como é o processo } \\
\text { do decaimento } \beta \\
\text { Apresentar o modelo } \\
\text { da força fraca e o } \\
\text { neutrino: sua } \\
\text { descoberta e } \\
\text { importância na energia } \\
\text { do Sol e das estrelas. } \\
\text { Discutir o decaimento } \\
\alpha, \text { a fissão e a fusão } \\
\text { nuclear. } \\
\text { Apresentar um } \\
\text { exemplo prático com a } \\
\text { datação do Carbono } \\
14 .\end{array}$ & \\
\hline
\end{tabular}




\begin{tabular}{|c|c|c|c|}
\hline $\begin{array}{l}\text { Diagramas } \\
\text { Feynman }\end{array}$ & & $\begin{array}{lr}\text { Mostrar } & \text { uma } \\
\text { representação possível } \\
\text { das } & \text { interações } \\
\text { estudadas. } & \\
\end{array}$ & \\
\hline $\begin{array}{l}\text { Criação e detecção de } \\
\text { partículas }\end{array}$ & $\begin{array}{l}\text { - Raios cósmicos - } \\
\text { César Lattes } \\
\text { - Aceleradores. }\end{array}$ & $\begin{array}{lr}\text { Apresentar } & \text { a } \\
\text { participação } & \text { dos } \\
\text { brasileiros na Física de } \\
\text { Partículas e mostrar o } \\
\text { princípio } \\
\text { funcionamento } \\
\text { aceleradores. }\end{array}$ & $\begin{array}{l}\text { Mostrar o site com } \\
\text { simulação dos raios } \\
\text { cósmicos: } \\
\text { www.lip.pt/experimen } \\
\underline{\text { ts/trc/opsao/oqsao3.ht }} \\
\underline{\underline{\mathrm{ml}}}\end{array}$ \\
\hline $\begin{array}{ll} & \\
& \\
\text { Modelo padrão atual e } \\
\text { classificação } \\
\text { "famílias" } \\
\text { partículas }\end{array}$ & $\begin{array}{l}\text { - O modelo padrão } \\
\text { - Características dos } \\
\text { BÓSONS e } \\
\text { FÉRMIONS. } \\
\\
\end{array}$ & $\begin{array}{l}\text { Apresentar o modelo } \\
\text { padrão atual da } \\
\text { estrutura da matéria. } \\
\text { Discutir a } \\
\text { classificação das } \\
\text { partículas através do } \\
\text { SPIN. } \\
\text { Mostra e discutir as } \\
\text { características dos } \\
\text { BÓSONS e } \\
\text { FÉRMIONS. }\end{array}$ & \\
\hline
\end{tabular}

A sequiência foi aplicada no segundo semestre de 2004. Porém, devido ao grande número de aulas perdidas com feriados, semana cultural, reuniões e outros acontecimentos na escola, não conseguimos terminá-la. Esse estudo piloto foi, contudo de grande utilidade para fazermos uma primeira avaliação da sequiência e das atividades que estavam sendo trabalhadas.

Nessa primeira avaliação notamos que a seqüência não estava bem estruturada, no sentido de colocar um problema para os alunos. A passagem do campo eletromagnético clássico para o quântico estava sendo feita de maneira não natural, de uma forma dogmática, fazendo com que os alunos não percebessem a diferença entre eles. Acreditando que poderíamos melhorar essa sequiência, na intenção de torná-la mais lógica, com conceitos bem interligados, tendo como inspiração, os problemas enfrentados pelos cientistas na estruturação dessa área, decidimos mudar a seqüência original.

Deste modo, a seqüência foi totalmente reestruturada. Depois de muita reflexão, conseguimos encontrar uma seqüência que tivesse uma linha condutora definida para a introdução da Física de Partículas; o fio condutor era o tópico: radiações. 
Iniciamos por radiações acreditando que esse tema, por estar bem próximo dos jovens, pode despertar algum tipo de interesse neles, principalmente quando se trata dos raios $\mathrm{X}$ e radioatividade. Um outro aspecto que contribuiu para nossa decisão de começar o curso por esse tópico, foi o caráter cronológico da história da Ciência. A partir das experiências com os tubos de raios catódicos, que investigavam as características dos gases quando atravessados por uma descarga elétrica, apareceram novas questões e fenômenos que instigaram os cientistas a buscar respostas mais "precisas" sobre a natureza da estrutura da matéria.

Assim, conseguimos montar uma seqüência de aulas, que privilegiava as partículas elementares e suas interações, sem nos aprofundarmos muito na natureza das radiações, visando não perdermos o foco, que é o estudo da Física de Partículas. A nova sequiência é apresentada na tabela a seguir:

\begin{tabular}{|c|c|c|c|}
\hline Tema & Conteúdo & \begin{tabular}{|c|} 
Objetivo \\
\end{tabular} & \begin{tabular}{|c|} 
Atividades \\
\end{tabular} \\
\hline Radiações & $\begin{array}{ll}- & \text { Raios-X e radiações } \\
& \alpha, \beta \text { e } \gamma \\
- & \text { Radiação } \\
\text { eletromagnética } \\
\text { - } & \text { Descoberta do elétron }\end{array}$ & $\begin{array}{l}\text { Mostrar que a partir da } \\
\text { descoberta do Raio-X, } \\
\text { novas questões surgiram } \\
\text { levando a descoberta } \\
\text { das radiações e da } \\
\text { primeira partícula: } \\
\text { elétron. }\end{array}$ & $\begin{array}{l}\text { - } \text { Atividade 0: Falando } \\
\text { sobre o que é } \\
\text { fundamental } \\
\text { (ANEXO II) } \\
\text { - Atividade 1: } \\
\text { Radiografias } \\
\text { (ANEXO II). } \\
\text { Vídeo da TV Ontário: a } \\
\text { descoberta } \\
\text { radioatividade }\end{array}$ \\
\hline Ordem de Grandeza & $\begin{array}{l}\text { - Ordem de grandeza e } \\
\text { dimensões }\end{array}$ & $\begin{array}{l}\text { Aprofundar a idéia da } \\
\text { ordem de grandeza e das } \\
\text { dimensões utilizadas, já } \\
\text { que estudaremos o } \\
\text { mundo microscópico, } \\
\text { onde esses conceitos } \\
\text { serão muito utilizados. }\end{array}$ & $\begin{array}{l}\text { Atividade 2: ordem de } \\
\text { grandeza e enxergando } \\
\text { o invisível (ANEXO II) } \\
\text { http://microcosm.web. } \\
\text { cern.ch/microcosm/P1 } \\
\text { 0/esp }\end{array}$ \\
\hline $\begin{array}{l}\text { Modelos atômicos e a } \\
\text { experiência de } \\
\text { Rutherford }\end{array}$ & $\begin{array}{l}\text { - Idéia grega de átomo; } \\
\text { - Modelo atômico de } \\
\text { Thomson; } \\
\text { - Modelo atômico de } \\
\text { Rutherford: } \\
\text { descoberta do núcleo } \\
\text { atômico; } \\
\text { - Modelo atômico de } \\
\text { Bohr. }\end{array}$ & $\begin{array}{l}\text { Discutir a evolução da } \\
\text { idéia de átomo desde os } \\
\text { gregos até Bohr, } \\
\text { mostrando como a } \\
\text { descoberta de novas } \\
\text { partículas modificou a } \\
\text { imagem da natureza. }\end{array}$ & $\begin{array}{l}\text { Atividade 3: } \\
\text { espalhamento } \\
\text { Rutherford (ANEXO } \\
\text { II) } \\
\text { Vídeo da TV Ontário: os } \\
\text { primeiros modelos/o } \\
\text { modelo de Rutherford }\end{array}$ \\
\hline $\begin{array}{l}\text { A estabilidade do núcleo } \\
\text { (radiação } \alpha \text { e a Força } \\
\text { Forte) }\end{array}$ & 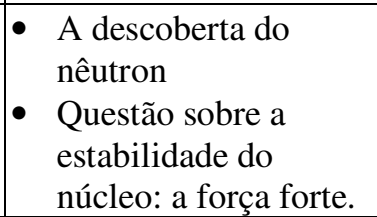 & $\begin{array}{l}\text { Entender que com a } \\
\text { descoberta do nêutron, a } \\
\text { estabilidade do núcleo } \\
\text { ficou comprometida, } \\
\text { sendo necessário buscar }\end{array}$ & \\
\hline
\end{tabular}




\begin{tabular}{|c|c|c|c|}
\hline & 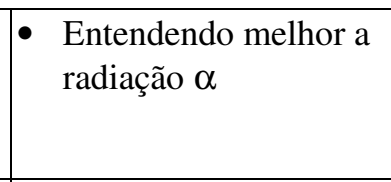 & $\begin{array}{l}\text { uma nova resposta para } \\
\text { essa questão. } \\
\text { Entender como ocorre a } \\
\text { radiação } \alpha \text {. } \\
\end{array}$ & \\
\hline Lattes e os Mésons & $\begin{array}{l}\text { - O Brasil na física de } \\
\text { partículas } \\
\text { - Raios cósmicos e os } \\
\text { aceleradores de } \\
\text { partículas } \\
\text { - As câmaras de } \\
\text { bolhas: como analisar } \\
\text { as fotos }\end{array}$ & \begin{tabular}{|l|} 
Mostrar a contribuição \\
de um brasileiro para a \\
Física de Partículas, \\
através da descoberta do \\
méson pi. \\
Entender o que são os \\
raios cósmicos, como \\
funcionam r os \\
aceleradores re de \\
partículas e a câmara de \\
bolhas.
\end{tabular} & $\begin{array}{l}\text { Atividade 4: } \\
\text { entendendo o } \\
\text { funcionamento dos } \\
\text { aceleradores de } \\
\text { partículas (simulação) } \\
\text { http://microcosm.web.ce } \\
\text { rn.ch/microcosm/RF_ca } \\
\text { vity/ex.html } \\
\begin{array}{l}\text { Mostrar o site com } \\
\text { simulação dos raios } \\
\text { cósmicos: }\end{array} \\
\text { www.lip.pt/experiments/ } \\
\text { trc/opsao/oqsao3.html } \\
\end{array}$ \\
\hline Modelo dos Quarks & $\begin{array}{l}\text { - A estrutura interna } \\
\text { das partículas } \\
\text { - A proposta do } \\
\text { modelo de quarks } \\
\text { - Carga cor }\end{array}$ & $\begin{array}{l}\text { Mostrar que } r \text { algumas } \\
\text { partículas }\end{array}$ & $\begin{array}{l}\text { Atividade 5: O modelo } \\
\text { dos quarks (ANEXO II) } \\
\text { Visita ao site: } \\
\text { www.pbs.org/wgbh/aso/ } \\
\text { tryit/atom (atom build - } \\
\text { Mattuck). }\end{array}$ \\
\hline Neutrino e a radiação $\beta$ & $\begin{array}{l}\text { - A descoberta do } \\
\text { neutrino: conservação } \\
\text { de energia e } \\
\text { momento } \\
\text { - Uma nova interação: } \\
\text { a força fraca } \\
\text { (decaimento } \beta \text { ) }\end{array}$ & $\begin{array}{l}\text { Discutir as idéias que } \\
\text { levaram a descoberta do } \\
\text { neutrino, quais } \\
\text { propriedades as dele, as } \\
\text { consequiências } \\
\text { levaram que para } \\
\text { formulação da interação } \\
\text { fraca. } \\
\text { Entender o processo da } \\
\text { radiação } \beta \text {. }\end{array}$ & \\
\hline $\begin{array}{l}\text { As novas leis de } \\
\text { conservação }\end{array}$ & $\begin{array}{l}\text { - As leis de } \\
\text { conservação para as } \\
\text { partículas. } \\
\text { - Partículas estranhas }\end{array}$ & $\begin{array}{llr}\text { Mostrar e discutir } & \text { as } \\
\text { novas } & \text { leis } & \text { de } \\
\text { conservação } & \text { para } \\
\text { partículas, como } & n^{\circ} \\
\text { bariônico e } \mathrm{n}^{\circ} \text { leptônico, } \\
\text { e r ainda } & \mathrm{o} \\
\text { comportamento estranho } \\
\text { de algumas partículas } \\
\text { (estranheza) }\end{array}$ & $\begin{array}{l}\text { Atividade 6: a regra do } \\
\text { jogo (ANEXO II) } \\
\text { Atividade 7: analisando } \\
\text { o sistema (ANEXO II) }\end{array}$ \\
\hline $\begin{array}{l}\text { Antimatéria e } \\
\text { antipartículas }\end{array}$ & $\begin{array}{l}\text { - A descoberta do } \\
\text { pósitron: as } \\
\text { antipartículas } \\
\text { - Aniquilação: } \\
\text { partículas x } \\
\text { antipartículas }\end{array}$ & $\begin{array}{l}\text { Mostrar a hipótese da } \\
\text { antipartícula proposta } \\
\text { por Dirac, que mais } \\
\text { tarde foi detectada e } \\
\text { como é o processo de } \\
\text { aniquilação e produção } \\
\text { das partículas e } \\
\text { antipartículas. }\end{array}$ & \\
\hline Uma nova concepção do & - O campo & Através da descrição & Atividade 8: A troca de \\
\hline
\end{tabular}




\begin{tabular}{|c|c|c|c|}
\hline campo eletromagnético & $\begin{array}{l}\text { eletromagnético } \\
\text { como interação de } \\
\text { partículas. } \\
\text { - Fóton: o mediador a } \\
\text { interação } \\
\text { eletromagnética }\end{array}$ & $\begin{array}{l}\text { feita para a interação } \\
\text { forte e fraca, } \\
\text { buscaremos fazer uma } \\
\text { descrição similar para o } \\
\text { campo eletromagnético } \\
\text { e o campo gravitacional, } \\
\text { mostrando como são } \\
\text { descritas } \\
\text { interações } \\
\text { quanticamente essas } \\
\text { são seus quantas. } \\
\end{array}$ & $\begin{array}{l}\text { fótons entre partículas } \\
\text { (ANEXO II). }\end{array}$ \\
\hline Diagramas de Feynman & 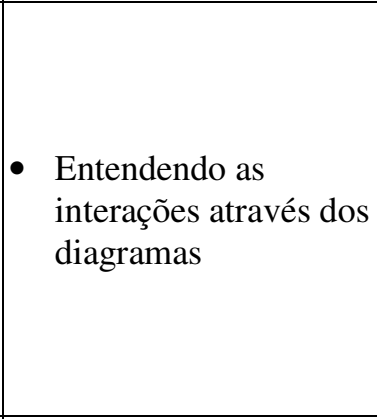 & $\begin{array}{l}\text { Discutir e mostrar como } \\
\text { podem ser descritas as } \\
\text { interações estudadas } \\
\text { através de diagramas } \\
\text { que simplificam e } \\
\text { formam uma idéia do } \\
\text { que está ocorrendo com } \\
\text { as partículas em seus } \\
\text { processos de decaimento } \\
\text { e interação. }\end{array}$ & \\
\hline $\begin{array}{l}\text { As famílias: Bósons e } \\
\text { Férmions }\end{array}$ & $\begin{array}{l}\text { - As partículas } \\
\text { mediadoras das } \\
\text { interações: os bósons. }\end{array}$ & $\begin{array}{lr}\text { Montar a grande } \\
\text { estrutura coerente das } \\
\text { partículas classificando- } \\
\text { as, através } & \text { dos } \\
\text { mediadores } & \text { das } \\
\text { interações. } & \\
\begin{array}{l}\text { Mostrar o } \\
\text { padrão atual. }\end{array} & \\
\end{array}$ & $\begin{array}{l}\text { Atividade 9: montagem } \\
\text { de um mapa conceitual } \\
\text { (ANEXO II) } \\
\text { Visita ao Pelletron }\end{array}$ \\
\hline
\end{tabular}

Com essa nova seqüência conseguimos chegar à sala de aula até os quarks, discutindo a constituição das partículas do núcleo ${ }^{28}$, no que diz respeito ao cronograma das aulas. Os problemas encontrados nessa segunda aplicação, não foram muito diferentes daqueles observados no primeiro caso. Várias vezes e por diferentes motivos, as aulas não ocorreram ${ }^{29}$, no entanto, nesse ano (2006) mais três professores aplicaram a sequiência.

Assim, acreditamos que, com essa sequiência didática, podemos abordar efetivamente em sala de aula os principais conceitos envolvidos na Física de Partículas Elementares, e gerar discussões acerca da história, filosofia e epistemologia da Ciência, mostrando assim, um pouco do funcionamento da Ciência Contemporânea, alcançando os objetivos propostos pelo curso.

\footnotetext{
${ }^{28}$ Apesar do curso não ter sido aplicado totalmente na sala de aula, conseguimos aplicar toda a seqüência com professores, em um curso de aperfeiçoamento ocorrido em junho de 2005 na FEUSP.

${ }^{29}$ Alguns dos motivos foram: dia dos professores, passeio a parques, visita a faculdades e conselhos de classe.
} 
Durante a construção de nosso curso, foi necessário, em alguns casos, abandonar a ordem cronológica do desenvolvimento da Física; por exemplo, a descoberta do pósitron foi feita cerca de duas décadas antes dos quarks, mas por um caráter didático, preferimos discutir os quarks antes das antipartículas. Assim, na nova estrutura do Saber da sala de aula, para o tempo didático, os quarks aparecem antes do pósitron (antipartículas), sendo essa inversão fruto de uma Transposição Didática. Esses afastamentos "devem ser compreendidos como uma inevitabilidade da transposição didática entre o saber sábio e o saber a ensinar.” (Astolfi \& Develay, 2006).

Assim, a sequiência que foi levada aos alunos é coerente, obedecendo a uma lógica didática e não cronológica. Porém, o aluno deve ter consciência de que os conceitos discutidos durante o curso, não estão em sua ordem de acontecimentos e devem perceber que uma adaptação foi feita para que um conhecimento científico pudesse se adequar à sala de aula e se tornar mais acessível.

Atentos ao complexo processo de mudança, que ocorre no conteúdo a ser adaptado para a escola, temos indícios de que foi possível apresentar aos alunos uma abordagem da Física de Partículas Elementares que escapa ao dogmatismo visto na grande maioria dos livros didáticos ${ }^{30}$. Para isso, desenvolvemos atividades, que buscavam levantar questões instigantes para os alunos e, assim, levá-los a entender um pouco mais dos fenômenos ligados ao intrigante mundo das partículas elementares.

Tais questões, apesar de terem sido inspiradas nos problemas enfrentados pelos físicos, foram adaptadas para serem inseridas na sala de aula, visto que, um problema para a Ciência, não é necessariamente, um problema para o aluno.

Além disso, foi necessário fazer uma ligação entre os conceitos, conferindo uma sequiência de ensino para esses conteúdos. Desta forma, foi imprescindível criar atividades problematizadoras, como textos com questões, animações, simulações de computador e outras atividades que levassem ao encadeamento do conteúdo, como, por exemplo, a atividade envolvendo os aceleradores de partículas.

\footnotetext{
${ }^{30}$ Ver análise feita no final do capítulo 4, página 87
} 


\section{5 - As atividades ${ }^{31}$}

Acreditamos que as atividades desempenham um papel fundamental em qualquer seqüência didática e, em nossa proposta isso não é diferente. Aqui elas dão um caráter mais dinâmico ao curso, fornecendo problemas aos alunos, problemas que servem de motivação para as discussões sobre os conceitos e tornando o desenvolvimento do curso, centrado em debates entre os alunos e o professor, de forma a modificar a atitude passiva do aluno diante do conteúdo.

A elaboração das atividades foram, sem dúvida, um dos grandes problemas enfrentados na confecção do curso, visto que, não é algo fácil levar um conhecimento pouco explorado didaticamente à sala de aula, uma vez que, as experiências realizadas demandam muito dinheiro e aparelhos altamente sofisticados, sendo quase impossível a realização de atividades práticas em sala de aula. Porém, com muita pesquisa teórica e a interação com os professores, conseguimos adaptar e montar algumas atividades que tornaram o curso mais dinâmico e menos monótono para os alunos.

Além do caráter dinâmico das atividades, elas também serviram como referencial de análise para o curso, já que as utilizamos como marcadores-estruturantes de nossa seqüência. A partir dos marcadores-estruturantes podemos avaliar se a seqüência com as atividades propostas se tornou coesa, lógica e possível de ser compreendida pelos alunos, e ainda, avaliar o entendimento do conteúdo. Essa ferramenta é motivadora para maiores discussões sobre o assunto. É nesse último aspecto, que as atividades desenvolvidas têm o seu papel principal. Elas foram elaboradas com o objetivo de gerar discussões e/ou apresentações de novos conceitos. Nesse sentido, as atividades tiveram um papel de problematizar o conteúdo, levando à reflexão sobre conceitos ligados à solução do problema ou elaboração de hipóteses para a solução do mesmo.

Por isso, elaboramos atividades ligadas aos principais conceitos que queríamos abordar, com o intuito de torná-los mais significativos para os alunos, e motivar o estudo da Física de Partículas.

${ }^{31}$ As atividades se encontram no anexo II desse trabalho. 
Por fim, as atividades também tiveram o papel de auxiliar no recorte dos conceitos, pois foi a partir delas que se iniciou a confecção da seqüência. A sequiência foi, portanto, construído em torno das atividades. 


\section{CAPÍTULO 4}

\section{A TRANSPOSIÇÃO DIDÁTICA}

\section{1 - Introdução}

Ao observar a Física que se encontra na sala de aula e compará-la com as pesquisas feitas pelos cientistas, nota-se, de certa forma, que existem algumas semelhanças entre elas. Entretanto, muito daquilo que se encontra em artigos de revistas das comunidades científicas, não está presente na sala de aula, nem mesmo nos livros textos utilizados nos curso de graduação das Universidades. Igualmente, pode-se notar, que alguns objetos encontrados no ensino, não existem na pesquisa em Física, como por exemplo, a associação de resistores. Desta forma, nota-se que o conhecimento sofre uma transformação, uma adaptação de sua origem para chegar à sala de aula.

Para tentar entender esse processo, se buscará, nesse capítulo, discorrer sobre um referencial de análise, que consiga refazer os caminhos percorridos pelo saber no processo de transformação, desde a sua origem, até chegar à sala de aula.

\section{2 - As Adaptações do saber para a escola}

Toda forma de conhecimento é "construída" por certa comunidade, ou seja, o conhecimento origina-se de uma fonte de produção. No caso da Física de Partículas, por exemplo, o conhecimento é produzido pelos pesquisadores (cientistas) em seus laboratórios altamente sofisticados, de custos elevadíssimos. Como foi discutido no capítulo 2, as pesquisas nesta área requerem altos investimentos, exigidos por cada experimento. Cada área de pesquisa têm suas especificidades determinadas pelo histórico de trabalho da comunidade, que se especializa na produção de conhecimento sobre os ramos do mundo físico.

Quando nos deparamos com a Física presente na sala de aula, percebemos que ela é muito diferente daquela originalmente desenvolvida pelos cientistas. Então vemos que 
a Física ensinada aos jovens, não é aquela produzida pelos cientistas, mas algo "transformado" para se adequar ao ambiente escolar.

Contrariamente a outras áreas, um jovem não lê diretamente os "Principia" de Newton, para estudar estática, ou o "Tratado de eletricidade e magnetismo" de Maxwell para estudar o eletromagnetismo. Com certeza, seria difícil e pouco operatório, o uso desses livros, pois foram direcionados aos pares (cientistas com formação específica). Eles são partes do debate da comunidade científica de uma época, e se constituíram como uma nova forma de conhecimento ou uma referência de conhecimento sobre determinado assunto. Nesse exemplo, o contexto histórico introduz uma componente fundamental, indicando que Newton e Maxwell, sejam autores presentes nos programas escolares de Física, mas, não sendo suas contribuições originais que devam tornar parte dos livros.

A mesma coisa aconteceria com os periódicos atuais das comunidades científicas, como Physics Review. Certamente, não seria possível utilizá-los como referência para o Ensino Médio. Cálculos diferenciais e gráficos são linguagens específicas, utilizadas pela comunidade científica para publicação de seus trabalhos, tornando-se barreiras intransponíveis para os adolescentes.

O conhecimento, desta forma, sofre uma adaptação para sala de aula, para que seja acessado por pessoas de fora da comunidade científica. Nessa adaptação, há uma modificação da linguagem, mais apropriada à comunidade escolar. Essa adaptação é algo necessário, já que ensinamos a Física do século XVI ao XIX, em apenas duas aulas em média, por semana em nossas escolas. Implicando que deve ser feita essa adequação do saber à realidade da sala de aula.

A adaptação pela qual o conhecimento passa, é, erroneamente pensada como uma mera simplificação do conhecimento, que na maioria das vezes se dá na linguagem dos conceitos, na demonstração de fórmulas matemáticas utilizadas como, por exemplo, a troca de "dx's" presentes nos livros universitários, por " $\Delta \mathrm{x}^{\prime} \mathrm{s}$ " dos livros do E. M. levando a idéia de que é exclusivamente isso que é feito com o conteúdo. Essa simplificação, na realidade, não é considerada uma transposição didática, pois o saber não está em outro nível. 
A adaptação do saber leva em conta uma série de fatores que influenciam na aprendizagem, tentando fazer com que este saber seja mais facilmente aprendido. Nessa adaptação são levados em conta os interesses da comunidade escolar, bem como a necessidade por um saber, que possa levar a um maior acesso ao mundo. Projetos escolares também influenciam nessa adaptação, como o ensino por competências, servindo como um norteador dos conteúdos a serem transformados.

Assim, transforma-se o conhecimento em sua seqüência (que, na maioria das vezes, é anacrônica), em sua linguagem gerando exercícios, problemas e atividades, visando sempre o seu ensino.

Ter consciência dessa transformação do conhecimento pelo professor, poderá fazer, com que ele compreenda melhor algumas seqüências didáticas, e também a relação envolvendo professor, aluno e conhecimento (saber), poderá melhorar o ensino e o aprendizado dos conteúdos de Física. Assim, o professor poderá compreender, que a seqüência didática utilizada nos livros e por ele próprio não é única. Ela depende de uma série de variáveis do ambiente onde o saber foi recontextualizado.

A relação entre professor, aluno e conhecimento é comumente formada no início de cada ano letivo. Os professores fazem o primeiro recorte de conteúdos que serão ensinados, durante o planejamento daquilo que deverá, inicialmente, ser apresentado para os alunos e de que forma isso será feito. Essa relação, que é formada a cada ano, é regida por um contrato didático ${ }^{32}$.

A escola desempenha um papel muito importante na sociedade, ela é a transmissora do conhecimento produzido pela humanidade, e, para desempenhar esse papel, necessita adequá-lo aos jovens, fazendo a adaptação do conhecimento. É a escola um dos locais privilegiados para as transformações do saber, desde seu ponto de referência, que é o conhecimento produzido pelos cientistas, até o conhecimento que é aprendido nas aulas, na tentativa de torná-lo mais acessível para uma parte da população. Ela norteia o que será transmitido e de que forma será feito.

${ }^{32}$ O Contrato Didático será discutido no tópico 3.4 
No ambiente escolar o ensino do saber sábio (saber produzido pelos cientistas) se apresenta no formato do que se denomina de conteúdo escolar ou conhecimento científico escolar. Este conteúdo escolar não é o saber sábio original, isto é, ele não é ensinado no formato original publicado pelo cientista, como também não é uma mera simplificação deste. O conteúdo escolar é um objeto didático, produto de um conjunto de transformações. (ALVES FILHO, 2000, p.219)

As transformações ocorridas no conhecimento, desde sua produção original nas comunidades científicas até chegar aos alunos nas salas de aula, podem ser analisadas através da Transposição Didática.

Desta forma, a Transposição Didática constitui-se numa ferramenta de análise para evidenciar os complexos processos subjacentes à construção dos conteúdos escolares. Segundo Alves Filho (2000, p.218):

A Transposição Didática se mostra um instrumento de análise do processo de transformação do conhecimento ou saber $^{33}$. Através dele é possível estabelecer uma argumentação para entender as diferentes formas do saber e suas estruturas organizacionais.

O conceito da Transposição Didática tem origem com o sociólogo Michel Verret, em 1975, na França. Porém, em 1982, Yves Chevallard e Marie-Alberte Joshua, utilizaram-no para "analisar e discutir as transformações sofridas com a noção matemática de distância, entre o momento de sua introdução em 1906, por Fréchet, no “saber sábio”, e o momento de sua introdução em 1971 nos programas de geometria da sétima série, em relação com a reta” (Astolfi \& Develay, 2006, p.47). Ou seja, eles analisavam a transformação do conhecimento matemático dos cientistas até a sua adequação às salas de aulas pelos professores, de uma maneira que os alunos pudessem compreender esse conhecimento.

Desta forma, a Transposição Didática pressupõe a existência de um processo, no qual "um conteúdo do saber tendo sido designado como saber sábio quando sofre, a

\footnotetext{
${ }^{33}$ Usaremos o termo saber em lugar do termo conhecimento, seguindo opção do autor. Os originais franceses utilizam savoir (saber), pois parece traduzir mais adequadamente o objeto do processo
} 
partir daí, um conjunto de transformações adaptativas que o levam a tomar lugar entre os objetos de ensino. $O$ trabalho em tornar um objeto do saber a ensinar em objeto do saber ensinado é denominado Transposição didática.” (Chevallard, 1991, p.45). Ou melhor, a Transposição Didática analisa as transformações ocorridas no saber de referência (Saber Sábio) até se tornar um saber da sala de aula (Saber Ensinado).

Essa ferramenta de análise propõe a existência de três níveis ou patamares do saber: o Saber Sábio (saber produzido pelos cientistas - saber original), onde se inicia o processo; o Saber a Ensinar (saber que faz parte dos currículos das escolas) e o Saber Ensinado (saber que, efetivamente, é levado para sala de aula e ensinado aos alunos). Cada um destes níveis têm sua própria comunidade autônoma, com seus representantes ou grupos. Ligando esses níveis tem-se a Noosfera, que se constitui numa esfera de ação onde os protagonistas atuam na transformação do saber. Essa esfera, envolve pessoas e/ou instituições que influenciam o sistema educacional, ou seja, todo personagem ou instituição social, econômica e política que influencia as transformações sofridas pelo saber, é considerado parte da noosfera. É nela, que ocorrem os conflitos inevitáveis às transformações dos saberes, onde os vários atores das diferentes esferas sociais negociam seus interesses, pontos de vistas e necessidades.

Na noosfera, pois, os representantes do sistema de ensino, com ou sem mandatos (desde o presidente de uma associação de professores até um simples professor militante), se encontram, direta ou indiretamente, (através do libelo denunciador, a demanda comunitária, o projeto transacional ou os debates ensurdecidos de uma comissão ministerial), com os representantes da sociedade (os pais dos alunos, os especialistas das disciplinas que militam em torno de seus ensinos, os emissários de órgãos políticos). (CHEVALLARD, 1991, p.28)

A Noosfera envolve o sistema didático ${ }^{34}$, tornando-se a dimensão onde são discutidos os problemas e debatidas as soluções pelos representantes principais do sistema didático, responsáveis pelo "bom" funcionamento dele. Ela envolve todos os representantes do sistema de ensino, como os autores de livros, os políticos

transformador da Transposição Didática do que o termo conhecimento (connassance), que aparenta ser de entendimento mais amplo e vago.

${ }^{34}$ Essa é uma noção introduzida por Chevallard (1991, p.15) que envolve o professor, o aluno e o saber através de uma relação didática. 
educacionais, pesquisadores em ensino, professores, representantes da sociedade, como os pais de alunos, especialistas das disciplinas e outros interessados no processo de ensino.

Assim, é nela que as exigências da sociedade são discutidas, tentando delimitar o que pode ser modificado e de que forma poderá ser feito para que o sistema didático atenda a essas exigências, se adequando da melhor maneira possível às necessidades da sociedade.

Desta forma, é no ambiente da Noosfera que ocorrem as negociações, as trocas de idéias, os conflitos, visando encontrar as soluções aos problemas trazidos pela sociedade, ou seja, "a Noosfera é a região onde se pensa o funcionamento didático" (Chevallard, 1991, p.28).

A Noosfera é então, o centro operacional do processo da Transposição Didática, onde se tenta delimitar as competências, as responsabilidades e os poderes de cada indivíduo que se encontram envolvidos nesse processo. É nela que se tenta definir os currículos face às necessidades, aos anseios da sociedade, fazendo o recorte do que se deve levar do saber original e como operar as transformações e novas introduções, visando à adequação ao ambiente escolar e ao projeto educacional. A Noosfera é, dessa forma, a responsável pelo fio condutor da Transposição Didática.

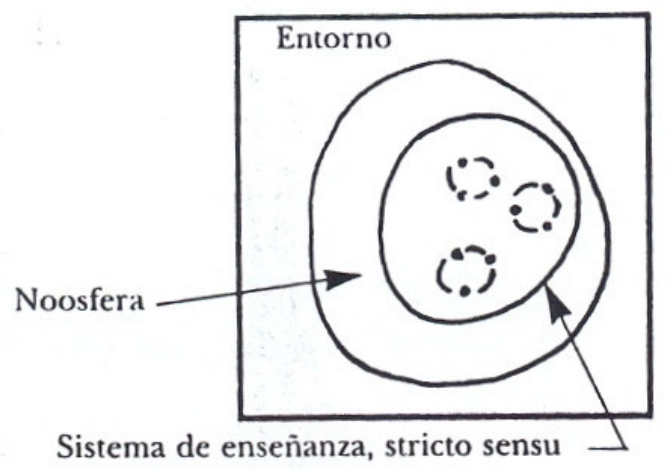

$(\text { Figura } 1)^{35}$

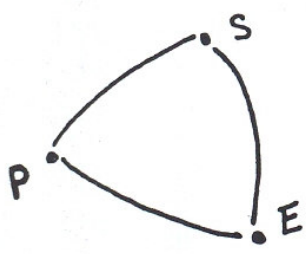

$(\text { Figura 2) })^{36}$

\footnotetext{
${ }^{35}$ Representação da Noosfera, com o sistema de ensino e seu entorno. (Chevallard, 1991, p.28)

${ }^{36}$ Representação do sistema didático (Chevallard, 1991, p.26)
} 


\section{3 - Os Saberes}

Agora, vamos analisar, separadamente, cada patamar do saber presente na Transposição Didática.

\subsection{1- Saber Sábio}

O Saber Sábio diz respeito ao saber original, aquele saber que é tomado como referência na definição da disciplinar escolar, sendo considerado o nível mais alto do saber no processo da Transposição Didática. O Saber Sábio é aquele construído no interior da comunidade científica. Esse saber passa por transformações no interior dessa comunidade, até tornar-se público, quando da publicação em revistas específicas das comunidades científicas (como, por exemplo, os artigos publicados na revista Physics Review, sendo objeto de debates, revisões e controvérsias). Antes da publicação é possível acessar o processo de construção específica da área científica em questão. Ao ser publicado, o conhecimento está limpo, depurado e em uma linguagem impessoal, que não retrata características de sua construção.

Esse patamar do saber é composto pelas pessoas responsáveis pela sua construção e desenvolvimento no interior das comunidades de pesquisa, isto é, os cientistas e pesquisadores de uma maneira geral. Sendo considerado, desta forma, o saber original, de onde se inicia todo processo da Transposição Didática.

A construção de um novo saber pelo cientista, normalmente se inicia com a busca por uma resposta ou solução de algum problema. Nesta busca, o cientista acaba por percorrer caminhos em seus raciocínios que não são descritos em seus artigos, devido ao grau de informalidade e subjetividade inerentes ao pensamento humano. Esse processo é denominado por Reichenbach (1961) de "contexto da descoberta", se referindo as etapas pouco objetivas, nas quais o cientista busca respostas pessoais a dado problema, porém, para formalizar sua solução, ele tem que abrir mão de toda a informalidade e emoção, fazendo análises e julgamentos da solução encontrada; pois somente assim, seu trabalho poderá receber a anuência da comunidade. Procedendo assim, ele estará à luz das condições de conhecimento presente na época, adequando seu trabalho às normas impostas pela comunidade científica, com uso de linguagem e regras 
peculiares a essa comunidade. A versão do conhecimento adentra assim ao referido, é denominado "contexto da justificativa" (Reichenbach, 1961). Ao final, o seu trabalho assume uma forma impessoal, sistemática, com começo, meio e fim, não expondo os conflitos ocorridos no contexto da descoberta.

Desde a descoberta até a publicação de um trabalho, vemos, nitidamente, dois momentos no processo total, e entre um e outro "há um processo de reelaboração racional que elimina elementos emotivos e processuais, valorizando o encadeamento lógico e a neutralidade de sentimentos. Aqui, de certa forma, há uma transposição não didática- mas, diríamos, científica caracterizada por uma despersonalização $e$ reformulação do saber”. (Alves Filho, 2001, p.224).

O tempo também é um aspecto importante, mas muitas vezes, deixado de lado no processo de construção do saber sábio. Em alguns casos, passa-se muito tempo para que seja encontrada a solução de um problema e para que ela seja aceita pela comunidade. No caso específico da Física de Partículas, tem-se vários exemplos da necessidade de se aguardar uma solução teórica e depois, mais algum tempo, para que as previsões teóricas fossem corroboradas pelos experimentos e, assim, serem aceitas pela comunidade científica. Este tempo é denominado, na T.D., de "tempo real", estando ligado ao processo histórico ao qual foi submetido o processo de construção do saber. No entanto, a versão pública do saber, publicado em revistas ou presente em livros de referência, apenas exibe o "tempo lógico", ligado às reconstruções racionais produzidas.

\subsection{2 - Saber a Ensinar}

Esse é o segundo patamar do saber, quando de sua primeira transposição. O processo de transformar o Saber Sábio em Saber a Ensinar, corresponde a “Transposição Didática Externa 37" (Chevallard, 1991). Esse processo se materializa, basicamente, na produção de livros didáticos, manuais de ensino e de programas escolares que têm como alvo os alunos universitários e professores do E.M. Embora os livros didáticos tenham os alunos do E.M. como público alvo, é, na verdade, o professor, o responsável por apresentar saberes ali presentes. Aqui, o conhecimento é 
reestruturado para uma linguagem mais simples adequando-se ao ensino, sendo "desmanchado", é reorganizado novamente de uma maneira lógica e atemporal (o saber é organizado de forma linear, não obedecendo a ordem cronológica da descoberta. Às vezes, utiliza-se de conceitos modernos inseridos no saber antigo).

É muito comum, à primeira vista, julgar que a transformação do saber para esse nível resulta de uma simples simplificação, deixando de lado os interesses sociais, políticos e econômicos da comunidade, que se caracterizam no projeto educacional dela. Como destaca Alves Filho (2000, p.225):

\footnotetext{
À primeira vista somos levados a interpretar que o saber a ensinar é apenas uma mera simplificação ou trivialização formal, dos objetos complexos que compõe o repertório do saber sábio. Esta interpretação é equivocada e geradora de interpretações ambíguas nas relações escolares, pois revela o desconhecimento de um processo complexo do saber.
}

No entanto, uma análise um pouco mais cuidadosa de materiais desse patamar do saber revela: 1) Ordenação de conteúdos presentes na esfera superior; 2) Introdução de conteúdos, técnicas e abordagens que visam atingir interesses externos à comunidade científica; 3) Superar conteúdos atuais em prol de conteúdos mais velhos e superados; 4) Ênfase em conteúdos considerados menos importantes, porém mais operacionais.

Os autores de livros didáticos, os especialistas das disciplinas, os professores, a opinião pública em geral, através do poder político que influencia de alguma maneira a transformação do saber, são exemplos dos atores desse patamar do saber. É esse grupo que vai determinar quais as transformações e o que deverá ser transformado do saber sábio em saber a ensinar, gerando um novo saber que estará mais próximo da escola.

Nesse processo, ao ser transformado em Saber a Ensinar, o saber sofre uma espécie de degradação ou uma descontextualização (Chevallard, 1991, p.53), ocorrendo a perda do seu contexto original, através de um processo que Chevallard denomina de despersonalização. O saber passa por uma espécie de demolição para que depois volte a ser reconstruído, permitindo uma nova estruturação e organização.

${ }^{37}$ Porque se processa fora do ambiente escolar, fora da escola. 
Assim, esse saber passa a ter uma configuração dogmática, ordenada, cumulativa e, de certa maneira, linearizada, tornando-se um saber com uma seqüência lógica. Com isso, ele perde o contexto de sua origem, passando a ter um novo contexto.

Uma outra função do saber a ensinar é fazer com que, o saber, perca qualquer ligação com o ambiente epistemológico no qual foi criado (Saber Sábio) através de um processo denominado de dessincretização (CHEVALLARD, 1991, p.69), sendo reconstituído em um novo contexto epistemológico.

Os processos de despersonalização, dessincretização e de
descontextualização, aos quais o saber é submetido, faz com que ele seja
despido de seu contexto epistemológico, histórico e linguagem própria.
Como saber a ensinar, é obtido um saber com uma nova roupagem, uma
organização a-histórica, um novo nicho epistemológico e de validade
dogmatizada. (ALVES FILHO, 2000, p.227)

É comum encontrarmos no Saber a Ensinar, devido à sua nova linguagem, situações ou termos que não se vê no Saber Sábio. Isso se dá, por uma necessidade de se racionalizar melhor as seqüências didáticas criadas a partir do saber de referência. Como destaca Alves Filho (2000, p.227), “a transposição muitas vezes necessita criar objetos de saber novos que não tem análogo no saber sábio, tendo uma criatividade didática, quer dizer criação de objetos que não figuram no saber sábio.”

Ao contrário do saber sábio, que depois de ser legitimado pela comunidade científica se torna parte da cultura da humanidade, o saber a ensinar e seus objetos podem não sobreviver até o final do processo da Transposição Didática, tornando-se obsoletos no contexto escolar ou banalizando-se no contexto sócio-cultural, sofrendo pressões de grupos provenientes da noosfera, e sendo descartados. Contudo, estas ações buscam um único objetivo: melhorar o ensino com o aumento da aprendizagem.

\subsection{3 - Saber Ensinado}

Esta é a segunda transposição do saber, que faz uma adaptação do conhecimento (saber) ao tempo didático, ou seja, é nesta etapa que há transformação do conhecimento visando o seqüenciamento das aulas. Nesta transformação do saber para sala de aula, 
aparece a figura do professor, que deve adequar o conhecimento trazido nos livros didáticos (saber a ensinar) para aquele que efetivamente vai para suas aulas fazendo-o chegar aos alunos. O professor é o principal personagem dessa transposição, desempenhando papel central nesse nível do saber, porém, não é o único: os alunos e a administração escolar (diretor, orientadores, pedagogas, etc...) também são representantes desse patamar na Noosfera. Este processo de transformação do saber a ensinar em saber ensinado é denominado “Transposição Didática Interna” (Chevallard, 1991), pois ocorre no interior do espaço escolar.

Esse é o saber que, de fato, chega ao aluno depois de sofrer dois recortes: Primeiro, através da Transposição externa, que transforma o saber original produzido pelo cientista em um saber com uma linguagem mais apropriada - o Saber a Ensinar; Segundo, a Transposição interna, processada pelo professor ao preparar a sua aula, que transforma esse saber em um saber que seja mais bem compreendido pelos alunos Saber Ensinado. Nessa transformação, o professor acaba sofrendo interferências de outros membros da Noosfera, devido à interação que ocorre entre eles. Isso faz com que, outros interesses, além dos seus, sejam levados em consideração no processo. Devido a isso, forma-se um novo ambiente epistemológico, porém muito mais instável, se comparado com o do Saber Sábio e do Saber a Ensinar. "Cada nova transposição cria um quadro epistemológico novo (...) Dentro de cada quadro novo, é feito o possível para reduzir as dificuldades de aprendizagem, dissolvê-las.” (Joshua e Dupin, 1993, p.201)

Todo início de ano letivo, o professor é requisitado a fazer um planejamento de tudo aquilo que pretende lecionar em uma determinada turma. Para isso, deve levar em consideração a quantidade de aulas que dispõe. Esse número de aulas é denominado de "tempo didático ou legal" cabe ao professor gerenciar esse tempo, de tal maneira, que cumpra aquilo que foi estabelecido no começo do ano letivo. Assim, o professor deve adequar o "tempo real" ao "tempo didático". Neste ponto, o processo de ensinoaprendizagem desempenha um papel relevante, pois é nele que será feita a ligação entre o "tempo real” e o "tempo didático".

O "tempo real" se traduz como sendo o tempo que é utilizado por uma série de personagens da Noosfera para produzir um saber. Já o tempo didático é um tempo muito 
bem definido no espaço escolar, para planejamento e organização do programa escolar. É exatamente neste ponto, que a Transposição Didática se faz necessária, justificando o seu papel transformador dos saberes, adequando-os da melhor maneira possível ao espaço escolar. Porém, o Saber Ensinado ao ser aprendido pelos alunos, define um novo tempo o "tempo de aprendizagem". Chevallard, diz não existir correlação entre o tempo de aprendizagem e o tempo didático, havendo jovens com tempo de aprendizagem distinto do tempo didático. Nesse ponto, a Transposição Interna desempenha um papel muito importante, fazendo com que o saber ensinado crie artifícios para que a diferença entre esses dois tempos seja a menor possível. Por exemplo, as classes de aceleração são recursos extremos que visam ajustar os dois tempos. Assim, podemos apresentar o seguinte esquema para o processo da Transposição Didática, que foi descrito aqui:

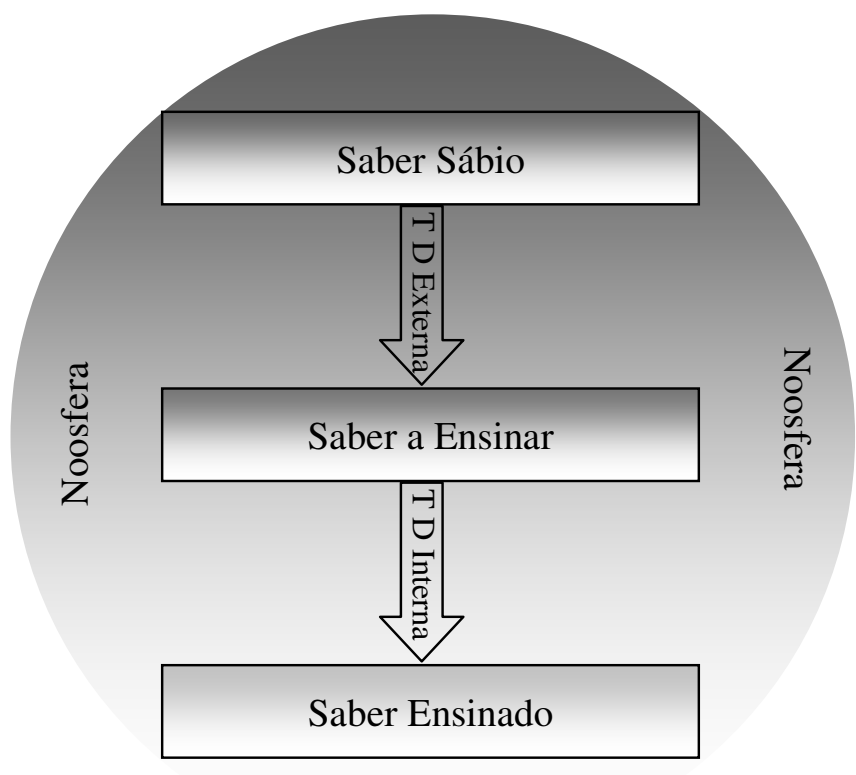

Nesse trabalho, como o nosso papel era preparar uma seqüência didática sobre Física de Partículas para aplicar no E.M., nos encontramos primeiramente no nível do Saber a Ensinar. Depois, juntamente com os professores, passamos a estabelecer o que de fato, chegaria ao aluno, ou seja, a preparar às aulas com eles, chegando ao nível do Saber ensinado. 


\subsection{4 - Como o saber sobrevive}

Como ferramenta de análise, a Transposição Didática consegue refazer os caminhos percorridos pelo saber, desde sua origem (Saber Sábio) até chegar a sala de aula (Saber Ensinado), deixando para a Noosfera o papel da seleção de quais serão os saberes do Saber Sábio que passarão pelas transformações para se adequarem à linguagem escolar.

Porém, para chegar ao professor, o saber tem antes, que sobreviver no patamar do Saber a Ensinar. Para isso, Chevallard destaca alguns indícios de características relevantes que o saber deve apresentar para permanecer no saber a ensinar. Essas características são:

- O saber tem que ser consensual. O saber que vai à sala de aula não pode apresentar dúvidas sobre seu status de "verdade", mesmo que seja um status momentâneo. Isso para que o professor não tenha medo de estar ensinando algo que a própria ciência não sabe se é verdade, e para que o aluno não tenha dúvidas sobre se o que está aprendendo é correto ou não. "O sistema de ensino parece não saber como avaliar aquilo que o aluno deve saber daquilo que a ciência ainda não sabe.” (Chevallard, 1991, p.69)

- O saber transposto deve buscar uma atualização. Espera-se que o saber que chega à escola reflita, da melhor maneira possível, o estágio atual de desenvolvimento da pesquisa. Com isso, a atualização se apresenta de duas maneiras: Atualidade moral, ligada ao currículo, mostrando se aquele saber que será transposto tem importância reconhecida pela sociedade e pelos pais, não se tornando um saber obsoleto que pode ser ensinado até mesmo pelos pais ou em outro ambiente que não seja a sala de aula. $\mathrm{Ou}$ seja, o saber que será transposto deverá estar nem muito afastado do saber de origem, nem muito próximo do saber de pais. Atualidade biológica, ligada diretamente a sua área de conhecimento. O saber transposto deve estar de acordo com a ciência vigente, deixando os conceitos que foram superados para serem ensinados somente em uma perspectiva histórica. 
- O saber tem que ser operacional. O saber que vai para sala de aula tem que ser capaz de gerar algum tipo de atividade, como exercícios, tarefas ou algum tipo de trabalho que tenha como objetivo a conceituação do saber, sendo possível formar seqüências didáticas. Essa é uma característica importante, porque está ligada diretamente à avaliação. Saberes que não apresentam nenhum tipo de atividade que possa levar a uma avaliação de seu aprendizado estão fadados a não permanecer na escola.

- O saber deve permite que haja uma criatividade didática. Essa característica implica na criação de atividades de uso exclusivo da escola, ou seja, objetos que não possuem similares no Saber Sábio, tornando-se criações que têm existência garantida somente na sala de aula, como é o caso de atividades que envolvam associação de resistores e escalas termométricas, por exemplo.

- O saber tem que ser terapêutico. O saber tem que mostrar uma adaptação ao sistema didático, ou seja, só permanece na escola aquele saber que já verificou que dá certo, dentro das características ressaltadas, e aqueles que não se ajustam ao sistema didático, são excluídos.

\subsection{5 - Práticas sociais de referência}

A noção de Práticas Sociais de Referência foi introduzida por Martinand (1986) e é de grande importância para o entendimento da Transposição Didática porque faz uma relação dos conteúdos com a cultura e com o cotidiano dos alunos. São as Práticas Sociais de Referência que dão significado extra-científico ao Saber Ensinado e, assim, permitem que ele seja mais bem compreendido pelo aluno. Essa é uma forma de legitimar o conteúdo que está na sala de aula (conteúdos com referências). De acordo com Astolfi \& Develay (2006, p.53):

Deve-se, de maneira inversa, partir de atividades sociais diversas (que podem ser atividades de pesquisa, de engenharia, de produção, mas também de atividades domésticas, culturais...) que possam servir de referência a atividades científicas escolares, e a partir das quais se examina os problemas a resolver, os métodos e atitudes, os saberes correspondentes. 
Isso faz com que os exemplos, exercícios ou problemas tenham um significado maior para os alunos e, desta forma, tornem-se um conhecimento mais atrativo e com possibilidade maior de ser aprendido.

As Práticas Sociais de Referência servem também de guia de análise, como destaca Martinand:

Funcionam essencialmente como guia de análise de conteúdo, de críticas e de proposição. A idéia de referência indica que não podemos e nem devemos nos ligar a uma conformidade estreita de competências para adquirir as funções, os papéis e as capacidades da prática real. Antes de tudo deve dar meios de localizar as concordâncias e as diferenças entre duas situações, onde uma (a prática industrial, por exemplo) é objeto ensinado, e possui uma coerência que deve ser transposta para a escola. (MARTINAND, 1986, apud, ALVES FILHO, 2000, p.222)

Desta forma, as Práticas Sociais de Referência servem para auxiliar e melhor sinalizar os possíveis saberes que poderão estar presentes na sala de aula, além de serem uma possibilidade de diminuir o dogmatismo imposto pelo processo da Transposição Didática do Saber Sábio ao Saber a Ensinar. Por estarem mais próximas do professor as Práticas Sociais de Referência, sinalizam uma possibilidade de realizar a transposição do Saber a Ensinar para o Saber Ensinado mais adequado para o ensino desse novo conteúdo (saber), possibilitando também o resgate da contextualização histórica da produção do saber sábio.

No caso da sequiência elaborada, as Práticas Sociais de Referência, serviram para buscar uma porta de entrada para o curso, sinalizando (indicando) uma atividade que fosse mais próxima dos alunos, tornando aprendizado deles mais significativo e mais contextualizado. 


\subsection{6 - As regras ${ }^{38}$ da Transposição Didática}

Analisando o processo da Transposição Didática, Astolfi (1997) pode estipular algumas regras para descrever o processo de transformação do Saber Sábio em Saber Ensinado, estabelecendo cinco regras.

A seguir vamos descrever "as várias etapas ou regras, que conduzem a introdução no saber sábio até o saber a ensinar” (Astolfi, 1997).

\section{Regra I - Modernizar o saber escolar}

A ciência, nos últimos anos, vem produzindo cada vez mais conhecimentos e estes chegam cada vez mais depressa para a população em geral, em forma de novos aparelhos e dispositivos mais modernos. Esse desenvolvimento poderia ser acompanhado por uma releitura moderna e contemporânea dos livros didáticos, fazenod juz ao alto desenvolvimento tecnológico. Isso poderia contribuir para um novo olhar do aluno sobre a Ciência moderna. De certa forma, isso já acontece, porém a maioria desses temas são tratados de forma superficial, ficando apenas como tópicos que permeiam a física clássica tradicional dos livros didáticos ou descritos brevemente nos últimos capítulos destes livros, nos mesmos moldes dos já existentes. “A modernização dos saberes escolares é uma necessidade, pois legitima o programa da disciplina, garantindo seu lugar no currículo.” (Brockington, 2005, p.109)

Em diferentes disciplinas, parece ser necessário aos especialistas colocar em dia os conteúdos de ensino para aproximá-los dos conhecimentos acadêmicos. Neste caso, freqüentemente criam-se comissões que tomam por base vários trabalhos e proposições anteriores difundidas na noosfera. (ASTOLFI, 1997, p.182)

\footnotetext{
${ }^{38}$ O termo regra, apresentado por Astolfi (1997) aparece com o significado de atributo apresentado pelos saberes. Porém, esses atributos somente são destacados depois do processo de transformação do saber já ter sido "processado" e não antes.
} 


\section{Regra II - Atualizar o saber escolar}

O saber tem que ser renovado, atualizado, porque esse saber tratado no sistema didático envelhece, "tornando-se velho em relação à sociedade” (Chevallard, 1991, p.30). Se afastado do núcleo de pesquisa do saber sábio (isso faz com esse saber não seja mais reconhecido como atual pelo saber original) e modificando-se para toda a sociedade, o saber do aluno estaria se aproximando do saber dos pais (banalizando o saber, porque o professor estaria ensinado algo diluído na cultura cotidiana). Esse envelhecimento torna o sistema didático obsoleto do ponto de vista da sociedade, visto que os próprios pais poderiam transmitir esse conhecimento. Isso gera uma incompatibilidade do sistema didático com seu entorno.

Para retomar a compatibilidade, é necessária a instauração de uma corrente proveniente do Saber Sábio que traga um saber ainda não difundido amplamente. "Para esta renovação, a modernização julgada necessária do lado do Saber Sábio, se soma a uma necessidade de renovação curricular do lado do ambiente do sistema educativo." (Astolfi, 1997, p.182)

\section{Regra III - Articular o saber novo com o antigo}

O saber novo se articula melhor quando apresentado para explicar um saber antigo, mas não de uma maneira radical, tentando refutar ou negar o saber anterior. Isso poderia gerar o risco de o aluno ver o novo saber escolar como algo instável, acreditando que ele sempre será substituído por um mais novo que virá em seguida. Poderá, também, gerar um estado de "questionamento" permanente, provocando dificuldades na condução do processo de ensino.

Entre os vários objetos do Saber Sábio suscetível a modernização e para diminuir a obsolescência, alguns são escolhidos porque permitem uma articulação mais satisfatória entre o novo que se tenta introduzir, e o velho já provado no sistema e do qual será necessário conservar alguns elementos reorganizados. (ASTOLFI, 1997, p.183) 


\section{Regra IV - Transformar um saber em exercícios e problemas}

O Saber Sábio que trouxer maiores possibilidades de exercícios e atividades, certamente será melhor aceito pelo sistema didático. Isso porque os exercícios e atividades são parte preponderante no processo de avaliação. Assim, esses conteúdos terão uma vantagem, ou melhor, uma preferência no processo da Transposição Didática. Pinho Alves (2001) destaca que essa é a regra de maior importância no processo de transformação do saber, pois está ligada diretamente ao processo de avaliação. A aquisição deste saber pelo aluno pode ser confirmada através da habilidade dele em solucionar exercícios e problemas.

A seleção vai ocorrer a partir da facilidade particular de certos conteúdos para gerar um número grande de exercícios ou atividades didáticas, até mesmo quando estes são nitidamente descontextualizados quanto a sua função, em relação ao conceito original. (ASTOLFI, 1997, p.183)

\section{Regra V - Tornar um conceito mais compreensível}

Como vimos, há uma perda da linguagem original na transformação do Saber Sábio em Saber a Ensinar. O saber passa a ser escrito em uma linguagem mais próxima das pessoas que não fazem parte da comunidade que compõe o Saber Sábio. Isso faz com que esse saber se torne mais próximo dos alunos e, desta forma, sua compreensão poderá ser facilitada, tendo como objetivo a melhoria do aprendizado desse saber por parte do aluno.

Um conceito [...] é visto como capaz de diminuir as dificuldades conhecidas como as que os alunos encontram. [...] a coisa do professor é um texto do saber. É então ao texto do saber que ele devolve a etiologia (ciência das causas) o fracasso e, por conseguinte, será nas variações do texto do saber que irá encontrar uma arma terapêutica para as dificuldades encontradas. Podemos aqui medir o caminho do que vai da primeira justificação que introduz o conceito, tal qual como aparece nas instruções, ao interesse que leva conscientemente o professor (diferentes daquele do programa) a este mesmo conceito. (CHEVALLARD \& JOSHUA, 1982) 


\section{4 - Contrato Didático}

\subsection{1- Introdução}

Com o processo da Transposição Didática, que transforma o saber de referência (Saber Sábio) em um saber que chega ao aluno (Saber Ensinado), inicia-se um outro processo nesse último nível do saber, o de ensino-aprendizagem, que se configura numa relação entre professor e aluno no ambiente escolar, tornando necessária uma análise mais detalhada dessa relação, complementando o último estágio do processo da transposição, quando esse novo saber é ensinado pelo professor e aprendido pelo aluno na sala de aula, sendo aquele saber que é aprendido ou assimilado.

No sistema didático (professsor-saber-aluno) existem regras que buscam estabelecer responsabilidades a cada uma das figuras presentes nele e elas são estabelecidas levando em conta o contexto histórico social e os fatores internos e externos, tentando formar um ambiente mais propício para a aquisição do saber por parte do aluno.

Dentro do sistema didático, se estabelece ainda, uma relação entre duas figuras de destaque: o professor e o aluno. Comumente, essa relação didática inicia-se no começo do ano letivo, período no qual aluno e professor passam a estudar um ao outro, tentando descobrir suas intenções, objetivos e interesses.

Porém nesse início, existe certo desequilíbrio dos atores em relação ao saber. “ $O$ aluno ainda não tem uma relação com esse tipo de saber e depende da mediação do professor, estando sujeito a um alto grau de controle por parte dele." (Pietrocola et al., 2002, p.2), e por isso, o aluno deposita sua confiança no professor, crendo que ele fará as escolhas adequadas e exigências compatíveis com o que foi ensinado. Já o professor, por conhecer toda a programação que será desenvolvida nas suas aulas, faz uma perspectiva do aprendizado do aluno, colocando metas e objetos na sua programação. Essa confiança mútua fundamenta a relação didática. 
Nesta confiança mútua entre professor e aluno, se sustenta a relação didática, estando apoiada principalmente nas relações que esses atores tem com o saber da sala de aula.

Quando o aluno percebe o que o professor espera dele nas avaliações, atividades e exercícios, ele compreende a relação didática, percebendo as "regras do jogo" ${ }^{39} \mathrm{e}$ começa a se sair bem no curso. Porém, qualquer mudança nessas regras comprometer o rendimento do aluno, ficando de fora da relação didática. Isto é o que acontece com aqueles alunos que não conseguem perceber as regras: eles acabam tendo problemas de aprendizado por não compreenderem a relação didática existente na sala de aula.

No entanto, nem sempre quem percebe as "regras do jogo" está aprendendo. Existem casos em que o aluno dá as respostas que o professor espera, mas continua acreditando naquilo que pensa ser a realidade, não expondo suas concepções alternativas porque não é exigido, seguindo duas lógicas bem distintas: a da sala de aula, respondendo o que o professor espera, e a de fora da sala, com suas concepções espontâneas ${ }^{40}$.

\subsection{2 - Instrumento de análise da ação pedagógica: O Contrato Didático}

Analisando as relações entre professor e aluno, que ocorrem no interior do sistema didático, Brousseau forja o Contrato Didático, que tem como objetivo definir uma abordagem teórica sobre essas relações.

O Contrato Didático é estruturado a partir da idéia de que o saber de referência (Saber Sábio), ao ser socializado, passa a configurar uma relação didática, se colocando a serviço do aluno. Esta relação entre professor, saber e aluno passa a ser gerenciada por regras que apontam o papel de cada um dentro da relação. A este conjunto de regras, Brousseau denominou de Contrato Didático e caracterizou como:

\footnotetext{
${ }^{39}$ Esse é um termo utilizado no trabalho de Pietrocola et al., 2002 que designa a compreensão do aluno sobre a relação didática.

${ }^{40}$ Aqui, me recordo de um episódio ocorrido comigo. Quando entrei no Ensino Médio, a primeira prova de Física que fiz, tirei zero, porque não entendia o que o professor falava, porém comparei as questões da prova com os exercícios do caderno e vi que eram idênticos. Então comecei a decorar as questões para prova e assim comecei a Ter um bom rendimento nas avaliações. Mesmo sem entender nada sobre o que discutido, fui rotulado como bom aluno, ou seja, eu entrei no jogo.
} 
[...] uma relação que determina, - explicitamente por uma pequena parte, mas, sobretudo implicitamente, - a cada parceiro, professor e aluno, a responsabilidade de gerir aquilo que, de uma maneira ou de outra, ele terá de prestar contas perante o outro. Esse sistema de obrigações recíprocas assemelha-se a um contrato. O que nos interessa é o contrato didático, ou seja, a parte deste contrato que é especifica do conteúdo. (BROUSSEAU, 1986, p.51, apud, PIETROCOLA et al., 2002)

Brousseau também faz referências aos aspectos paradoxais do contrato didático em relação ao professor e ao aluno.

Para o professor, que tem papel distinto do aluno, o paradoxo se encontra na própria ação dele enquanto agente transmissor do saber. Como destacam Pietrocola et al., " a situação paradoxal reside no fato de que tudo que o professor ensina ou explica ao aluno, tira deste a oportunidade de aprender." (Pietrocola, et al., 2002, p.03), ou seja, ao mesmo tempo em que a figura do professor se faz necessária na intermediação da relação didática, ele não pode minar as condições do aluno para aquisição do saber.

O aluno poderá se encontrar também em situação paradoxal quando aceitar ajuda do professor para chegar na resposta pretendida. O paradoxo aí se dá na intervenção do professor. Ao intervir, ele impede o aluno de construir o conhecimento, tomando seu espaço no sistema didático, e se não intervem, a relação didática perde sua característica, tornando o aprendizado inviável devido às dificuldades intrínsecas do saber.

Contudo, as características de um Contrato Didático são definidas nas particularidades de cada sistema didático, dependendo da abordagem, da metodologia e do objetivo que o professor tem ao transmitir um determinado saber. Segundo Pietrocola et al (2002):

[...] as características de um Contrato Didático não são definidas apenas a partir da natureza da área ou especificamente pelo tema objeto de estudo, mas também, em função da concepção de mundo, da concepção de Ciência e ensino e Ciência das quais o professor é portador. (PIETROCOLA et al., p.4) 
Ao procurar desempenhar o seu papel, o professor acaba se deparando com o problema dos paradoxos que aparecem nas relações didáticas. Contudo, cabe a ele gerenciar e administrar ambas as situações paradoxais para que o Contrato Didático não sofra rupturas gerando uma crise nas relações didáticas e, conseqüentemente, no sistema didático, podendo levar à perda de confiança e à descaracterização do papel de cada um dos atores envolvidos no processo de ensino-aprendizagem.

Pietrocola et al. (2002) propõem uma saída para gerenciar essas situações: “uma maneira de gerenciar esse paradoxo poderá ser pela introdução de pequenas “perturbações” no contrato estável. Acreditamos que a introdução de problemas com inovações inesperadas pelos alunos é uma ferramenta pedagógica importante.” (p.6)

No entanto, não podemos esquecer que a prática pedagógica possui uma perspectiva diretiva. Se de um lado, comporta certa dinâmica, podendo ser alterada em função das demandas cognitivas e fatores internos e externos que influenciam o processo de ensino, por outro lado, apresenta uma espécie de "núcleo duro" que permanece inalterado em função da assimetria que há nos papéis que professor e aluno desempenham numa relação didática. 


\section{5 - A Física de Partículas com o olhar da Transposição Didática}

Como vimos, para que um novo saber permaneça ou sobreviva nos livros didáticos e chegue até o professor e à sala de aula, deve apresentar as características indicadas como relevantes por Chevallard. Assim, se pretendemos inserir a Física de Partículas Elementares no Ensino Médio, esse novo saber deverá apresentar estas características.

A partir de agora, iremos analisar a Física de Partículas Elementares enquanto Saber a Ensinar com a ferramenta da Transposição Didática.

A Física de Partículas Elementares é uma área da Ciência Contemporânea que busca compreender de que forma os constituintes elementares da matéria se interagem e que procura responder a duas questões primordiais: quais são os constituintes elementares da matéria? Quais são as forças e leis fundamentais que agem sobre os constituintes?

$\mathrm{Na}$ busca desses objetos, ela fez com que a visão de mundo fosse modificada, passando por várias maneiras de ser interpretada até chegar à forma atual ${ }^{41}$. Além disso, as pesquisas atuais nessa área trouxeram um grande avanço tecnológico para a sociedade, mas ainda há muito o que se pesquisar. Muitas questões ainda estão em aberto, fazendo com que configure, atualmente, entre as três maiores áreas da pesquisa científica (Genoma Humano, Cosmologia e Partículas Elementares), mostrando estar presente na pesquisa de ponta, na fronteira da ciência.

Desta forma, é possível levar essa área de conhecimento para o E.M., tentando mostrar aos jovens alunos uma visão mais atual da estrutura da matéria, acessando o mundo microscópico, que é descrito, com teorias para as interações, e, ainda, fazer com que eles interajam mais com a ciência, compreendendo um pouco do que está sendo feito hoje nos laboratórios mais sofisticados do mundo. Além disso, esse conteúdo pode mostrar um pouco mais sobre o funcionamento da ciência, que é dinâmica e passível de mudança, contribuindo, assim, para uma aproximação maior do aluno com a ciência e

\footnotetext{
${ }^{41}$ Essas mudanças tiveram início na antiguidade com os gregos, que tentavam interpretar os constituintes primordiais da matéria através de duas linhas, uma monista, que acreditava em um único elemento primordial e os pluralistas, que acreditavam que a matéria era constituída de mais de um elemento.
} 
eliminando alguns estereótipos trazidos por seus preconceitos sobre a Física e o cientista.

\begin{abstract}
O assunto pode ser tratado historicamente, com apresentação das diversas teorias que se sucederam, levando os alunos a perceberem que os conhecimentos científicos não são verdades absolutas, sendo um aspecto importante da visão atualizada das ciências. (ALVARENGA, 1994, p.191) ${ }^{42}$
\end{abstract}

Como uma área de conhecimento, a Física de Partículas procura descrever as partículas e as interações entre elas através do Modelo Padrão ${ }^{43}$. Apesar de não ser o único modelo que busca descrever as partículas e suas interações, é o mais aceito pela comunidade científica, podendo ser considerado consensual por grande parte dos cientistas. Creio que se perguntarmos aos físicos qual o modelo que descreve a estrutura da matéria atualmente, provavelmente, responderiam o Modelo Padrão.

Além disso, a Física de Partículas traz uma atualização do saber que já se encontra em sala de aula, através de uma nova visão da natureza, feita pelo Modelo Padrão atual. Nele, o modelo de átomo, que antes era constituído de partículas até então elementares (próton, elétron e nêutron, como visto nas aulas de química e até mesmo nas aulas de eletromagnetismo), passa a ser concebido de outra maneira, com os quarks (constituintes dos prótons e nêutrons) e os elétrons, levando a uma visão contemporânea e atual do átomo, tentando romper com o modelo planetário tão freqüentemente apresentado nas aulas de Ciência.

Pode-se ter também uma atualização no modelo que descreve a interação entre as partículas, mostrando que é apresentado por uma troca de partículas mediadoras, denominadas bósons, justificando, assim, a atualidade biológica. "A Física de Partículas Elementares pode servir para uma releitura da Física Clássica, como por exemplo, as interações que, do ponto de vista da FMC, são entendidas através da troca de uma partícula mediadora.” (Ostermann \& Moreira, 2000, p.394). Contudo, não é necessário refutar totalmente a visão clássica de campo, podendo esse ser utilizado para a análise de objetos macroscópicos, onde se tem uma grande quantidade desses bósons, ${ }^{42}$ Alvarenga, Beatriz in: Caruso e Santoro. Do átomo grego à Física de interações fundamentais. $2^{\mathrm{a}}$
edição, Rio de Janeiro: CBPF, 2000. 
tornando a descrição do campo um ente contínuo. Assim, como a cinemática newtoniana ainda é válida para velocidades baixas, o campo clássico ainda se torna válido para descrições macroscópicas.

Com referência à atualização moral, podemos justificá-la como sendo um conteúdo que venha mostrar o que se pesquisa nos laboratórios atualmente, tendo a cada dia, um avanço na descrição da matéria e da antimatéria, e, conseqüentemente, na tecnologia gerada por ela. Também se pode compreender um pouco mais sobre as radiações discutindo a radiação cósmica e as outras radiações como a $\alpha$ e $\beta$, levando a um entendimento maior de aparelhos como os raios-X, as tomografias e até do processo de geração de energia nas usinas nucleares. Desta forma, justifica-se a presença da Física de Partículas no currículo por ser um saber que está longe do alcance dos pais e muito presente na sociedade moderna.

Como um saber atual, ela também se destaca por ser uma área bem contemporânea. Para tanto, basta lembrarmos que o quark top foi descoberto em 1995 e que, atualmente, são feitas muitas pesquisas que tentam encontrar respostas para questões intrigantes como, por exemplo, por que existe mais matéria do que antimatéria?

A procura de partículas constituídas por cinco quarks, os pentaquarks e a procura dos bósons de Higgs, responsáveis pela massa das partículas, continuam sendo uma área de grandes investimentos e muitas investigações. Além disso, vale destacar que o prêmio Nobel de Física de 2004 foi entregue ao grupo que faz pesquisa na área da Cromodinâmica Quântica - QCD.

Quanto à operacionalidade, acreditamos que esse tópico apresenta grande potencial para criação de atividades como exercícios, problemas e até mesmo algum tipo de atividade prática que possa vir a instigar o aluno. E ainda, por apresentarem uma área pouco explorada na sala de aula, essas atividades podem fugir dos modelos presentes no ensino de tópicos que já se encontram na escola como a cinemática, a termometria e a eletrostática.

${ }^{43}$ Ver página 43, capítulo 2. 
A Física de Partículas no Ensino Médio pode se relacionar com a criatividade didática, pois não há ainda um elemento que esteja presente somente na sala de aula, não tendo um análogo no saber sábio, já que não se tornou um conteúdo que, de fato, esteja presente no saber escolar. Talvez esse possa ser um indício que mostra porque a Física de Partículas Elementares não está presente no E.M. e que, provavelmente, quando estiver, poderá ter esse objeto didático. Aquela parte que se encontra nos livros de Física do E.M. não apresenta nenhum tipo de criatividade está fortemente estruturada na forma tradicional, ou seja, nos moldes dos conteúdos que já se encontram nos livros.

Talvez no caso da FMC, principalmente a Física de Partículas Elementares, a criatividade didática, esteja intimamente ligada à terapêutica, formando assim, objetos didáticos que através de relatos isolados de aplicação de professores indicam se deram certo ou não. 


\section{6 - Livro didático: A Física de Partículas como Saber a Ensinar}

O Saber a Ensinar, como foi visto, é aquele saber que já passou por um primeiro processo de transformação e adaptação do saber original, o Saber Sábio. Na maioria das vezes, o Saber a Ensinar se concretiza em manuais de ensino, como os livros didáticos, que representam algumas propostas de ensino, no nosso caso, propostas para o Ensino Médio. Assim, os livros didáticos representam um objeto importante no processo de transformação do saber, uma vez que servem de referência aos professores, que os torna um Saber Ensinado, e possa chegar, de fato, aos alunos, ou seja, os livros didáticos são um dos principais meios de acesso do jovem à Ciência.

Desta forma, realizamos um levantamento nos livros didáticos mais comuns do Ensino Médio sobre os conteúdos referentes à Física de Partículas Elementares para, que assim, possamos ver como esse Saber a Ensinar se concretiza.

O levantamento de tópicos sobre à Física de Partículas Elementares foi feito nos seguintes livros:

- Física: História \& Cotidiano - Bonjorno e Clinton, V.3, São Paulo, FTD, 2003.

- As Faces da Física - Carron, W. e Guimarães, O., V. único, São Paulo, Moderna, 1997.

- Física para o Ensino Médio - Gonçalves Filho, A. e Toscano, C., V. único (Série Parâmetros), São Paulo, Scipione, 2002.

- Física - Sampaio \& Calçada, V. único (Coleção Ensino Médio), São Paulo, Atual, 2003.

- Física: Eletromagnetismo e Física Moderna - Gaspar, A., São Paulo, Ática, 2003.

- Imagens da Física - Amaldi, Ugo. São Paulo: Scipione, 1995.

- Curso de Física - Alvarenga, Beatriz; Máximo, Antônio, V.1, V.2, V.3. São Paulo: Scipione, 2000.

- Física Conceitual - Hewitt, Paul. Porto Alegre: Bookman, 2002.

- Tópicos de Física 3 - Gualter, Newton, Helou, V.3, São Paulo: Saraiva, 2001.

- Física Básica - Ferraro, Nicolau Gilberto; Soares, Paulo Antônio de Toledo. V. único, São Paulo: Atual, 2004. 


\begin{tabular}{|c|c|c|c|}
\hline Livro & $\begin{array}{c}\mathrm{n}^{\mathbf{0}} \text { de páginas destinadas } \\
\text { ao conteúdo }\end{array}$ & Presença de atividades & Tópicos tratados \\
\hline \multirow{8}{*}{$\begin{array}{c}\text { Física } \\
\text { SAMPAIO \& CALÇADA } \\
472 \text { páginas }\end{array}$} & \multirow{8}{*}{10 páginas (cap. 74 ) } & \multirow{8}{*}{5 exercícios } & O átomo (concepção grega e o desenvolvimento) \\
\hline & & & Força Forte (interação forte) \\
\hline & & & Algumas partículas elementares \\
\hline & & & Produção de pares (partículas e antipartículas) \\
\hline & & & Decaimento beta (antineutrino) \\
\hline & & & Quarks e antiquarks \\
\hline & & & Classificação das partículas (léptons, mésons e bárions) \\
\hline & & & Unidade de massa e energia (elétron-volt) \\
\hline
\end{tabular}

\begin{tabular}{|c|c|c|l|}
\hline Livro & $\begin{array}{c}\mathbf{n}^{\mathbf{0}} \text { de páginas destinadas } \\
\text { ao conteúdo }\end{array}$ & Presença de atividades & \multicolumn{1}{c|}{ Tópicos tratados } \\
\hline $\begin{array}{c}\text { As Faces da Física } \\
\text { CARRON \& GUIMARÃES } \\
\text { 672 páginas }\end{array}$ & 2 páginas (cap.51 e 52) & Nenhuma & A estrutura do átomo \\
\cline { 3 - 4 } & O núcleo e os seus constituintes \\
\hline
\end{tabular}

\begin{tabular}{|c|c|c|l|}
\hline Livro & $\begin{array}{c}\mathbf{n}^{\mathbf{0}} \text { de páginas destinadas } \\
\text { ao conteúdo }\end{array}$ & Presença de atividades & \multicolumn{1}{|c|}{ Tópicos tratados } \\
\hline $\begin{array}{c}\text { Física para o Ensino Médio } \\
\text { GONÇALVES FILHO \& } \\
\text { TOSCANO } \\
\text { 480 páginas }\end{array}$ & 3 páginas (p.307-309) & \multirow{2}{*}{8 exercícios } & Descoberta do elétron e do núcleo \\
\cline { 3 - 4 } & & & Modelo de Thomson e Rutherford (próton e nêutron alfa \\
\hline
\end{tabular}




\begin{tabular}{|c|c|l|l|}
\hline Livro & $\begin{array}{c}\mathbf{n}^{\mathbf{0}} \text { de páginas destinadas } \\
\text { ao conteúdo }\end{array}$ & Presença de atividades & \multicolumn{1}{c|}{ Tópicos tratados } \\
\hline $\begin{array}{c}\text { Física: História e Cotidiano } \\
\text { BONJORNO \& CLINTON } \\
\text { 455 páginas }\end{array}$ & 3 páginas (p.334 à 337) & Nenhuma & Modelo de Bohr \\
\cline { 3 - 4 } & & Modelo atômico atual \\
\cline { 3 - 4 } & & Léptons, mésons, bárions, quarks e antipartículas. \\
\hline
\end{tabular}

\begin{tabular}{|c|c|c|c|}
\hline Livro & $\begin{array}{c}\mathbf{n}^{\mathbf{0}} \text { de páginas destinadas } \\
\text { ao conteúdo }\end{array}$ & Presença de atividades & Tópicos tratados \\
\hline $\begin{array}{c}\text { Física Fundamental } \\
\text { BONJORNO \& CLINTON } \\
672 \text { páginas }\end{array}$ & 0 (zero) & Nenhuma & Não foi encontrado nada sobre o conteúdo \\
\hline
\end{tabular}

\begin{tabular}{|c|c|c|c|}
\hline Livro & $\begin{array}{c}\mathbf{n}^{\mathbf{0}} \text { de páginas destinadas } \\
\text { ao conteúdo }\end{array}$ & Presença de atividades & Tópicos tratados \\
\hline $\begin{array}{c}\text { Tópicos de Física } 3 \\
\text { GUALTER, NEWTON E } \\
\text { HELOU } \\
\text { 460 páginas }\end{array}$ & 0 (zero) & Nenhuma & $\begin{array}{l}\text { Apesar de conter um capítulo sobre a Física Moderna, } \\
\text { não há quase nada sobre a Física de Partículas, somente } \\
\text { a Teoria da Relatividade e o caráter dual da luz. }\end{array}$ \\
\hline
\end{tabular}

\begin{tabular}{|c|c|c|c|}
\hline Livro & $\begin{array}{c}\mathrm{n}^{\mathbf{0}} \text { de páginas destinadas } \\
\text { ao conteúdo }\end{array}$ & Presença de atividades & Tópicos tratados \\
\hline \multirow{4}{*}{$\begin{array}{c}\text { Física: Eletromagnetismo e } \\
\text { Física Moderna } \\
\text { GASPAR } \\
448 \text { páginas }\end{array}$} & \multirow[t]{4}{*}{20 páginas } & \multirow{4}{*}{$\begin{array}{c}1 \text { atividade } \\
10 \text { questões } \\
1 \text { questão de vestibular } \\
2 \text { exercícios }\end{array}$} & Descoberta dos raios-X, radioatividade e radiação $\alpha$ e $\beta$; \\
\hline & & & Átomo de Rutherford e Bohr \\
\hline & & & Spin do elétron \\
\hline & & & Princípio da exclusão de Pauli; \\
\hline
\end{tabular}




\begin{tabular}{|l|l|l|}
\hline & & $\begin{array}{l}\text { Descoberta do nêutron, do pósitron, do neutrino e do } \\
\text { píon; }\end{array}$ \\
\cline { 3 - 3 } \\
$\begin{array}{l}\text { Quadra) } \\
\text { massa }\end{array}$
\end{tabular}

\begin{tabular}{|c|c|c|c|}
\hline Livro & $\begin{array}{c}\mathbf{n}^{\mathbf{0}} \text { de páginas destinadas } \\
\text { ao conteúdo }\end{array}$ & Presença de atividades & Tópicos tratados \\
\hline $\begin{array}{c}\text { Física Básica } \\
\text { NICOLAU \& TOLEDO } \\
\text { 640 páginas }\end{array}$ & 0 (zero) & Nenhuma & $\begin{array}{l}\text { Apesar de conter um capítulo de Física Moderna } \\
\text { (Relatividade e Introdução a Mecânica Quântica), não } \\
\text { há tópicos ligados a Física de Partículas. }\end{array}$ \\
\hline
\end{tabular}

\begin{tabular}{|c|c|c|c|}
\hline Livro & $\begin{array}{l}\mathrm{n}^{\mathbf{0}} \text { de páginas destinadas } \\
\text { ao conteúdo }\end{array}$ & Presença de atividades & Tópicos tratados \\
\hline \multirow{11}{*}{$\begin{array}{c}\text { Física Conceitual } \\
\text { HEWITT } \\
685 \text { páginas }\end{array}$} & \multirow{11}{*}{$\begin{array}{l}14 \text { páginas (cap. 11) } \\
4 \text { páginas (Cap. 32) } \\
6 \text { páginas (Cap. 33) }\end{array}$} & \multirow{11}{*}{$\begin{array}{c}55 \text { questões de revisão } \\
60 \text { exercícios } \\
8 \text { problemas }\end{array}$} & A hipótese do átomo \\
\hline & & & Raios $\mathrm{X}$ e radioatividade \\
\hline & & & Radiações alfa, beta e gama \\
\hline & & & A descoberta do elétron, do próton e do nêutron \\
\hline & & & O núcleo atômico \\
\hline & & & Modelo atômico de Bohr \\
\hline & & & Quarks \\
\hline & & & Antimatéria \\
\hline & & & Matéria escura \\
\hline & & & Detectores de radiação \\
\hline & & & Transmutação. \\
\hline
\end{tabular}




\begin{tabular}{|c|c|l|l|}
\hline Livro & $\begin{array}{c}\mathbf{n}^{\mathbf{0}} \text { de páginas destinadas } \\
\text { ao conteúdo }\end{array}$ & Presença de atividades & \multicolumn{1}{c|}{ Tópicos tratados } \\
\hline & & & Relação entre massa e energia \\
$\begin{array}{c}\text { Curso de Física } \\
\text { ALVARENGA \& MÁXIMO }\end{array}$ & V.1 (Cap. 8) & \multirow{2}{*}{ 11 exercícios de fixação } & Aniquilação de um par \\
\cline { 3 - 4 } 3 volumes (1237 páginas) & V.3 (Cap.23 e 25) & & A descoberta do nêutron \\
\cline { 3 - 4 } & & & As partículas elementares (léptons e quarks) \\
\cline { 3 - 4 } & & & A descoberta do elétron \\
\hline
\end{tabular}

\begin{tabular}{|c|c|l|l|}
\hline Livro & $\begin{array}{c}\mathbf{n}^{\mathbf{0}} \text { de páginas destinadas } \\
\text { ao conteúdo }\end{array}$ & Presença de atividades & \multicolumn{1}{|c|}{ Tópicos tratados } \\
\hline \multirow{3}{*}{$\begin{array}{c}\text { Imagens da Física } \\
\text { AMALDI } \\
\text { 537 páginas }\end{array}$} & \multirow{2}{*}{20 páginas } & \multirow{2}{*}{ Nenhuma } & A descoberta do elétron, do próton e do nêutron. \\
\cline { 3 - 3 } & & & A força fraca e o neutrino \\
\cline { 3 - 4 } & & & Radiações alfa, beta e gama. \\
\cline { 3 - 4 } & & & Transmutação dos elementos. \\
\hline
\end{tabular}


Notamos com este levantamento, que alguns livros didáticos editados no Brasil tratam tópicos da Física de Partículas Elementares. Contudo, na maioria deles, o conteúdo é trazido nos últimos capítulos, sendo tratado na sala de aula quando há tempo disponível, o que é pouco provável de acontecer nas escolas públicas no Brasil, já que na maioria delas só há duas aulas de Física por semana.

Podemos destacar também que ainda faltam muitos tópicos que acreditamos ser relevantes para o estudo das Partículas Elementares como, por exemplo, a evolução do conceito de átomo juntamente com a idéia do que é elementar, idéia esta que foi evoluindo paralelamente com a descoberta de novas partículas; a descrição quântica dos campos; o confinamento dos quarks; a classificação mais detalhada das partículas, seja através de seu spin, seja através das interações.

Sentimos falta também de uma abordagem sobre as questões que motivaram os cientistas a fazer novas investigações, acreditando que sejam relevantes de serem tratadas nos livros, pois podem mostrar um pouco sobre o desenvolvimento científico, diminuindo a distância entre os jovens e a ciência, contribuindo para derrubar estereótipos criados pelos conteúdos tradicionais, uma vez que os livros didáticos continuam contribuindo para uma visão linear e acabada do conhecimento Físico.

O livro Física Conceitual, de Paul Hewitt, nos chamou atenção por trazer uma variedade de exercícios e questões, que se distanciam dos padrões tradicionais dos livros didáticos, tendo uma preocupação com os conceitos estudados e não com o mero caráter informativo do conteúdo. Infelizmente, é um livro caro para os padrões brasileiros, por se tratar de uma tradução de uma versão norte-americana, mas vale como incentivo aos autores de livros didáticos nacionais, pois traz uma maior preocupação com os conceitos e os fenômenos ligados a Física de Partículas Elementares.

Não tivemos a pretensão de fazer uma análise profunda e detalhada dos livros didáticos, mas somente de destacar quais tópicos de Física de Partículas são tratados neles. Assim, concluímos que a maioria dos livros tem a maior parte de seu conteúdo sendo trabalhado nos moldes tradicionais dos conteúdos já existentes neles, levando a uma descrição muito superficial da Física de Partículas Elementares, deixando de lado 
muitos aspectos importantes para a discussão dos conceitos, principalmente a fenomenologia tão rica dessa área.

Esse levantamento foi importante para indicar os caminhos que não gostaríamos de seguir em nossa sequiência; a abordagem utilizada e a ausência de tópicos que pensamos serem essenciais para uma melhor compreensão da Física de Partículas Elementares, conforme discutimos no capítulo 3 (página 47). 


\section{CAPÍtULO 5}

\section{A METODOLOGIA DE PESQUISA}

\section{1 - Considerações iniciais}

Há pelo menos duas décadas, a atualização curricular é uma questão importante de pesquisa no ensino de Física ${ }^{44}$. A maioria das pesquisas encontradas nessa direção mostram que é possível atualizar os currículos do Ensino Médio por meio da introdução de tópicos de Física Moderna e Contemporânea. Porém, elas se restringem somente ao "por que fazer" e "se é possível fazer", deixando de lado a esfera do "como fazer". O intuito deste trabalho é contribuir para as pesquisas no nível do "como fazer", mostrando uma dessas possibilidades.

Assim, foi elaborada uma seqüência didática sobre Física de Partículas que introduz os principais conceitos dessa área que acreditamos estar ao alcance dos alunos. Pensamos que com a elaboração da sequiência didática, estaremos aptos a responder a seguinte questão: Como ensinar a Física de Partículas para estudantes do Ensino Médio?

Para auxiliar a análise dos dados, buscou-se na literatura uma metodologia que se enquadrasse da melhor maneira possível ao desenvolvimento do trabalho e à ferramenta de análise - A Transposição Didática mostrando uma maneira mais fiel para a coleta de dados e as diversas formas possíveis para isso.

\footnotetext{
${ }^{44}$ Ver capítulo 1 , item 1.1
} 


\section{2 - A metodologia de pesquisa}

Para realizar uma pesquisa é preciso promover o confronto entre os dados, as evidências, as informações coletadas sobre determinado assunto e o conhecimento teórico acumulado a respeito dele. É importante frisar que a pesquisa, como atividade humana e social, traz junto diversos valores, preferências, interesses e princípios que acabam por orientar o pesquisador que faz uso desses aspectos do ponto de vista da sua época. Normalmente, quando se fala em pesquisa, pensa-se logo numa pessoa em um laboratório manipulando substâncias, ajustando equipamentos, olhando em um microscópico, entre outras atividades características de um pesquisador "padrão" da área das ciências naturais e biológicas. Nessa visão, a metodologia de análise dos dados segue um padrão (modelo), ou seja, os dados são constantes no tempo e no espaço. Isso significa que um dado coletado em um determinado local, pode ser analisado em qualquer lugar do mundo (Essa é a realidade atual da pesquisa em Física de Partículas: Têm-se poucos aceleradores que fornecem dados para serem analisados por grupos de pesquisadores em vários pontos do mundo). Esse é o tipo de pesquisa caracterizado como quantitativa.

Inicialmente, essa metodologia utilizada pelas ciências naturais e biológicas foram tomadas de empréstimo e aplicadas em campos específicos das ciências humanas, como a psicologia e a sociologia etc. Por muito tempo, pensou-se que a pesquisa em educação pudesse seguir os modelos das ciências exatas, nas quais se pode isolar uma variável e analisar a sua influência no fenômeno em questão. No entanto, na área de Educação, e nas ciências humanas de maneira geral, isso não ocorre. Os objetos de análise são complexos e, entre outros problemas, não há possibilidade de tratá-los de maneira generalizada. Na maioria dos casos, "as variáveis" estão intimamente ligadas, não podendo haver a análise de apenas uma parte do fenômeno, porque essa parte perde suas características fora do todo, ou seja, a parte, sem o todo, não é parte. Nesse sentido, Lüdke \& André (1986) dizem:

Com a evolução dos próprios estudos na área da educação, foi-se percebendo que poucos fenômenos nessa área podem ser submetidos a esse tipo de abordagem analítica, pois em educação as coisas acontecem de maneira tão inextricável que fica difícil isolar as variáveis envolvidas e mais ainda apontar claramente quais são as responsáveis por determinado efeito. (p.3) 
Em vez da ação de uma variável dependente, o que ocorre em Educação é, em geral, a múltipla ação de inúmeras variáveis agindo e interagindo ao mesmo tempo. Ao tentar isolar alguma dessas variáveis, está se optando, necessariamente, por uma redução do foco do estudo a uma parte do fenômeno.

Lüdke \& André (1986) destacam ainda que um estudo analítico pode ser tentado, porém corre-se o risco de levar a "complexa realidade do fenômeno educacional a um esquema simplificador de análise” (p.4).

Contudo, no desenvolvimento das pesquisas nessa área, esse paradigma positivista $^{45}$ (Lüdke \& André, 1986) foi deixado de lado. Desta forma, a pesquisa em Educação passou por uma reformulação, "criando" uma outra maneira de coletar e analisar dados, dando conta do caráter dinâmico e complexo que há na Educação. Tratase da investigação qualitativa.

Por esse motivo, optamos por fazer uma pesquisa qualitativa, acreditando que ela possa fornecer uma visão mais apurada do fenômeno educacional. Acreditamos também, que esse tipo de pesquisa possa levar a resultados mais significativos do que uma pesquisa quantitativa, já que estamos lidando com um ambiente complexo. O sistema didático (aluno - professor - conhecimento), juntamente com as relações entre seres humanos e conhecimento, torna-se, assim, algo muito complexo, que não permite ser analisado e quantificado.

Na pesquisa qualitativa, o papel do pesquisador não é considerado neutro, quando em atividade ele não pode ser parcial, interferindo nos processos de tomada e análise de dados com suas idéias, valores e princípios. Assim, o pesquisador é como um veículo inteligente e ativo entre os conhecimentos que ele tem acumulado na sua área e as novas evidências que serão estabelecidas a partir de sua investigação. É com esse trabalho que o pesquisador acrescenta novos conhecimentos sobre o objeto investigado. Contudo, essa contribuição poderá conter uma carga particular, que é a visão do pesquisador, pois esse não consegue ser totalmente neutro sobre o assunto. Essa é uma característica bem definida na pesquisa quantitativa. Isso faz com que o pesquisador qualitativo seja diferente do pesquisador quantitativo.

\footnotetext{
${ }^{45}$ Tipo de pesquisa utilizado pela Ciências exatas
} 
Neste trabalho, utilizaremos elementos da investigação qualitativa que possam nos fornecer dados para analisar o processo no qual o saber (conhecimento) se estabelece em sala de aula, ou seja, vamos buscar dados em um ambiente que já conhecemos (a sala de aula), focando na estrutura dos conteúdos escolares produzidos (seqüência didática).

Como já dito anteriormente, desenvolvemos uma seqüência didática sobre Física de Partículas e aplicamo-la numa sala de aula de uma escola pública da rede estadual de São Paulo, buscando assim o ambiente real da sala de aula para obter dados significativos possíveis. Construímos nossa ferramenta de análise por meio da Teoria da Transposição Didática, que já mostrou ser capaz de lidar com a sobrevivência de saberes escolares em sala de aula (Pinho, 2000; Rodrigues, 2001; Brockington, 2005). Vamos analisar se esse novo conteúdo sobrevive ou não no sistema didático, através das regras sugeridas pela Transposição Didática. Desta forma, poderemos falar em um novo conteúdo que venha a contribuir para a renovação e atualização curricular de Física.

Como o tipo de pesquisa exige que se avaliem as possibilidades de introdução de saberes contemporâneos em sala de aula, optamos por utilizar a Transposição Didática como forma de analisar esse processo. A metodologia utilizada só poderia ser qualitativa e apoiada nas concepções presentes na Transposição Didática. Acreditando, que neste caso, ela possa levar a uma melhor análise e a uma melhor visão do processo de transformação do saber, dando um panorama mais amplo da seqüência didática e das atividades. Lembramos ainda que a Transposição Didática, como referencial de análise, não tem o intuito de tecer juízo de valor sobre o conteúdo em si, dizendo se ele é bom ou ruim. O seu objetivo é dizer se esse novo saber poderá permanecer na sala de aula, tornando-se um saber escolar. Como destaca Alves Filho (2000):

\footnotetext{
A Transposição Didática não é boa nem ruim - faz-se indispensável imperativa, pois torna ensinável os saberes. Ela mostra como a didática opera para facilitar o ensino de conteúdos do saber sábio. A transformação de objetos de saber em objetos de ensino se faz imprescindível para que ocorra de fato um processo de ensino aprendizagem. (p.234)
}

Um ponto importante que destacamos é que a análise será feita exclusivamente focando a seqüência didática. Assim, aspectos como aprendizagem, a relevância do 
papel do professor para ensinar esse conteúdo, foram deixados de lado na análise. Contudo, esses pontos foram levados em consideração no momento de aplicação e adequação do saber e das atividades, pois a aprendizagem do aluno acaba fazendo com que algumas abordagens e discussões do curso sejam modificadas.

Enfim, podemos considerar que a nossa pesquisa será, de alguma forma, um relato de uma longa viagem empreendida, vasculhando um lugar que já foi muitas vezes visitado: o sistema didático. Não há, com isso, nada de muito original em um passeio no local já conhecido, porém, essa nova viagem (pesquisa) passa a ser um modo diferente de olhar e pensar determinada realidade a partir de uma experiência e de uma apropriação de conhecimento, próprio do nosso olhar. E, a partir de nossos questionamentos, descreveremos novas evidências sobre esse lugar, contribuindo para uma descrição mais detalhada desse ambiente. Somente dessa forma poderemos delimitar, cada vez melhor, o conhecimento sobre o ambiente investigado.

\subsection{1 - A tomada de dados}

Um aspecto importante da pesquisa qualitativa é a tomada de dados, pois esses não são meramente dados colhidos para uma análise estatística (pesquisa quantitativa) e sim observações (inferências) sobre um objeto complexo, que se modifica constantemente. Isso faz com que a análise dos dados seja feita levando em consideração fatores sociais, econômicos, históricos, entre outros. Ou seja, na análise deve-se levar em conta como os dados foram tomados. Devemos ainda considerar a nossa interferência no processo. Mesmo tentando ser imparcial na coleta e análise dos

dados, sempre iremos interferir no ambiente. Desta forma, buscaremos várias fontes de dados para chegarmos às conclusões mais fiéis possíveis.

A tomada de dados foi feita de diversas maneiras, para que assim, pudéssemos obter dados suficientes para análise. As três fontes utilizadas foram: gravações das aulas (áudio e vídeo), análise de produção dos alunos e questionários. 


\section{A gravação das aulas: observações}

A primeira fonte da coleta de dados foi a gravação das aulas. Essas gravações foram feitas em áudio e vídeo. As falas dos alunos durante as aulas foram o foco de nossa análise, principalmente, no desenrolar das atividades e na exposição dos problemas.

Esse tipo de coleta de dados foi feito visando captar as imagens dos alunos que estavam em contato com o material produzido na seqüência didática, as atividades e o próprio conteúdo apresentado durante as aulas, buscando desta forma, captar as impressões deles nas discussões, o levantamento de hipóteses nas atividades e a estranheza que alguns conceitos poderiam gerar nesses jovens. Assim, pudemos elaborar melhor as conclusões sobre o curso, fazendo, quando possível, uma triangulação de dados. Desta forma, acreditamos que as conclusões possam ser mais fiéis ao que ocorreu de fato no ambiente escolar.

Inicialmente, as gravações eram feitas no laboratório de informática da escola, onde ocorriam as aulas. Nesse local, a câmera permanecia no canto da sala (ao lado da lousa, oposta à porta de entrada), procurando captar todos os alunos. Devido à manutenção que estavam fazendo nos computadores, o professor foi obrigado a mudar para a sala habitual da turma. A posição da câmera era a mesma do laboratório de informática, ou seja, no canto da sala. O responsável pelas gravações foi o próprio pesquisador, que estava no ambiente exclusivamente para isso, não tendo nenhuma participação nas discussões e atividades das aulas.

\section{O questionário}

Outra fonte de dados é o questionário, uma vez que este pode oferecer a visão do aluno sobre a estrutura do curso.

Como o nosso objetivo era verificar se a sequiência didática proposta pode se tornar um saber escolar, focamos o questionário em perguntas relacionadas aos textos, às atividades, exercícios, provas e a todo tipo de material utilizado na elaboração e aplicação dessa seqüência. (anexo II) 
Tentamos resgatar também, com o questionário, as impressões que os alunos tiveram no decorrer do curso, buscando compreender melhor o que eles pensavam sobre o texto, as questões referentes a elas e as atividades.

Além disso, acreditamos que o questionário possa ser um momento em que o aluno estará mais livre para descrever as suas reais impressões sobre a seqüência didática, já que os questionários são anônimos, ou seja, não foi necessária a identificação do aluno.

\section{Análise dos documentos}

Primeiramente, entendemos como documentos "quaisquer materiais escritos que possam ser usados como fonte de informação sobre o comportamento humano." (Phillips, 1974, p.187, apud Lüdke \& Anadré, 1986, p.38). Desta forma, serão analisadas todas as atividades escritas, todas as questões que foram respondidas e as avaliações feitas pelos alunos.

O objetivo dessa coleta foi tentar resgatar as conclusões tiradas pelos alunos nas diversas discussões e também, as hipóteses levantadas por eles na resolução das atividades, mostrando a maneira que ele está pensando e estruturando os diversos conceitos discutidos.

\subsection{2 - O local de aplicação}

O curso foi aplicado em duas escolas da periferia da cidade de São Paulo (capital). Uma no bairro Cidade Ademar, Escola Estadual João Evangelista Costa e a outra no bairro Jardim Campo de Fora, Escola Estadual Miguel Munhoz Filho. Ambas situadas na Zona Sul.

Nessas escolas, o curso foi aplicado em duas turmas (uma em cada escola) da terceira série do Ensino Médio, do noturno, em seu horário normal de aula e obedecendo ao calendário escolar, ou seja, o curso não fazia parte de uma atividade 
extraclasse e sim, do planejamento dos professores para as turmas. Por serem do noturno, as aulas tinham uma grade diferente da grade das turmas do diurno ${ }^{46}$. À noite, as escolas têm somente quatro aulas por dia, totalizando 20 aulas semanais. Logo, há um déficit de 5 aulas por semana em relação ao diurno, totalizando, em média, uma perda de 250 aulas ao ano (cada aula tem 50 minutos em qualquer turmo).

A segunda escola (E.E. Miguel Munhoz Filho), na qual tive a oportunidade de acompanhar todo o curso, por meio das filmagens, está situada em uma região muito carente de São Paulo (região do Capão Redondo), e foi dessa escola que coletamos os dados para análise. Um aspecto em destaque na aplicação do curso nessa turma é que ele era aplicado nas duas últimas aulas de sexta-feira e, por várias vezes, o número de alunos presentes era alto, em torno de $80 \%$ e somente essa turma permanecia na escola até o final do período. Também várias vezes, ficamos discutindo a aula com alguns alunos depois do horário normal, até sermos (pesquisador e o professor da turma) "expulsos" da sala de aula pelo pessoal da escola que queriam fechá-la e ir embora.

Na outra escola, E. E. João Evangelista Costa, houve também a coleta de dados, porém ela se restringiu somente a gravações de áudio, que não ficaram muito boas. Tivemos a oportunidade de recolher todo o material escrito pelos alunos. Esses materiais também serviram de fonte de análise para esse trabalho, podendo fazer uma comparação entre os alunos das duas escolas.

\subsection{3 - As características da turma}

A turma da qual descreveremos algumas características, pertencia a Escola Estadual "Miguel Munhoz Filho". .

A turma era formada por 42 alunos que se encontravam matriculados (nomes presentes no diário de classe), sendo que efetivamente, somente 37 participaram do curso. Era uma turma do terceiro ano do ensino médio (denominada G4 pela escola), com um comportamento e aprendizagem mediana na avaliação dos professores que nela

\footnotetext{
${ }^{46}$ Esse ano, 2006, as aulas do noturno das escolas públicas estaduais, passaram a ter cinco aulas por dia, com um tempo de 45 minutos cada. Permanecendo ainda um pequeno déficit no tempo em relação aos outros turnos (manhã e tarde)
} 
lecionavam. A faixa etária dos alunos variava entre os 16 e os 22 anos. A condição sócio-econômica deles era mais homogênea: a grande maioria pertence à classe baixa.

Nos dias em que havia algum tipo de reunião, festividades ou passeio em outras turmas, a presença geral na escola era baixa, inclusive no G4. Isso por que a grande parte dos alunos trabalhava durante o dia e ia para escola à noite assistir às aulas. E, como as gravações eram feitas nos dois últimos horários da sexta feira ${ }^{47}$, boa parte da turma não comparecia às aulas, dificultando o desenvolvimento do curso, pois o professor não gostava de aplicar o curso para poucos alunos em sala.

A turma foi bem receptiva com o curso e tivemos a impressão de que, em nenhum momento, houve uma rejeição dele. Os alunos somente estranharam muito a forma como os exercícios e questões eram tratados, pois não havia uma resposta direta nos textos. Eles tinham que ler e interpretar para depois responder. Isso fez com que eles pensassem e discutissem mais entre si sobre o assunto, já que as atividades e os textos eram estudados sempre em grupo.

\section{3 - A figura do professor}

Muito se fala em melhorar o ensino de ciências nas escolas do Brasil e, para isso, são feitas diversas pesquisas que procuram apontar quais são os principais problemas enfrentados no ensino dessa área. Porém, muito dessas pesquisas não chegam ao protagonista da mudança, o professor.

O professor, em sua prática diária, acaba não participando muito dessas pesquisas e, assim, não sabe como solucionar os problemas que, muitas vezes, ele já conhece bem. Em alguns casos, essas pesquisas não levam em conta a formação do professor. Por isso, é necessário que as pesquisas possam interagir mais com os docentes, não só do E.M. É de extrema importância a criação de grupos de pesquisas, a criação de mais cursos de formação continuada, encurtando o espaço entre pesquisas e professor para que, desta forma, as propostas que buscam a melhoria do ensino não sejam esquecidas, ou feitas em vão, como diz Carvalho:

${ }^{47}$ A aula era das 21:00h até às 22:40h. 
Nenhuma mudança educativa formal tem possibilidade de sucesso se não conseguir assegurar a participação ativa do professor, ou seja, se, de sua parte, não houver vontade deliberada da aceitação e aplicação dessas novas propostas de ensino. (CARVALHO, 2004, p.8)

A formação de grupos de pesquisas envolvendo professores do E.M. é de suma importância para encurtar a distância entre as Universidades e as escolas, principalmente as públicas, que carecem de um ensino de qualidade, de professores com formação específica que estejam buscando a melhoria do ensino.

Nesse sentido, trabalhamos com professores que já participam, há algum tempo, de um grupo de pesquisa que busca a melhoria do ensino de Física no Ensino Médio. Esse grupo, que já havia trabalhado em um projeto que tinha como objetivo a melhoria do ensino da Termodinâmica no E.M. das escolas públicas de São Paulo (FAPESP 98/1078-1), era composto por docentes e pós-graduandos da Faculdade de Educação da USP e docentes da rede pública do estado de São Paulo, e agora, está inserido em um projeto que busca atualizar o currículo de Física do E. M., através de propostas de conteúdos de Física Moderna e Contemporânea. Atualmente, o grupo é constituído de dois docentes da Faculdade de Educação, quatro pós-graduandos, seis docentes da rede pública estadual (sendo que destes quatro são pós-graduandos e um já possui o título de mestre) e quatro alunos de iniciação científica.

Inicialmente, trabalhamos com dois professores do grupo que se dispuseram a aplicar uma versão do curso de Física de Partículas. Ambos possuem uma grande experiência na área do magistério e ainda têm uma boa formação, sendo licenciados pelo instituto de Física da USP. Os trabalhos com esses professores foi desenvolvido no Laboratório de Pesquisa em Ensino de Física (LaPEF) vinculado à Faculdade de Educação da Universidade de São Paulo, com o apoio da FAPESP.

Durante todo o ano de 2005, foram feitos encontros semanais às terças feiras para que pudéssemos, inicialmente, discutir conjuntamente as atividades que seriam aplicadas com a discussão dos conceitos envolvidos, visto que se tratava de uma área com pouco conhecimento por parte dos professores, já que, possivelmente, não tiveram uma disciplina específica sobre esse conteúdo na graduação. Assim, durante o tempo 
que estávamos juntos, podíamos discutir o conteúdo que seria trabalhado e como as atividades seriam aplicadas com os alunos ao longo do curso. Pois, além de saber o conteúdo, o professor também deveria saber como aplicá-lo em sala de aula, conforme destacam Carvalho \& Gil-Perez (2001), “o professor deve saber o conteúdo e saber fazer" (saber avaliar, saber aplicar as novas abordagens e as novas atividades em sala de aula).

Os professores desempenharam um papel de suma importância na estruturação das atividades na sequiência, pois foram os norteadores das nossas idéias, ou seja, eram eles que diziam o que teria grande chance de ser bem aceito pelos alunos ou não, participando ativamente no processo da Transposição Didática.

Eles também participaram bastante da confecção das atividades, discutindo as melhores adaptações a serem feitas para que os alunos pudessem compreender e trabalhar essas atividades. Assim, a presença deles, tanto na confecção quanto na aplicação, foi muito importante para a legitimação do curso, fazendo o vínculo entre realidade dos alunos e a das escolas. 


\section{CAPÍTULO 6}

\section{A ANÁLISE DOS DADOS}

\section{1 - Introdução}

Neste capítulo serão apresentados os dados obtidos em nossa pesquisa. Para isso, construiremos um instrumento a partir da Transposição Didática para analisar a estrutura do curso, centrada nos "marcadores" e no desenvolvimento (aplicação) das atividades que fazem parte dele.

A noção de marcador foi forjada por Brockington (2005) para analisar uma seqüência didática sobre o comportamento dual da luz:

\footnotetext{
O termo marcador foi cunhado durante nossas reflexões sobre a necessidade de buscar novos rumos para a inserção da FMC nas salas de aula. Por tratarse de um "terreno ainda não desbravado", nosso trabalho, analogamente, se assemelhava à abertura de trilhas. Com isso, seria preciso deixar marcadores pelos caminhos que criávamos, para indicar se deveriam, ou não, serem posteriormente seguidos. (BROCKINGTON, 2005, p.158)
}

Essa noção nos pareceu adaptada para analisar seqüências didáticas que estruturam propostas de cursos. A idéia trazida por Brockington, será também utilizada por nós. Porém, acreditamos que os marcadores, além de demarcar um caminho num campo em exploração, explicitam também atividades estruturadoras. Ou seja, são atividades que, combinadas, caracterizam e estruturam o curso. Usaremos então a noção de marcadores-estruturantes para definir aquelas atividades que serão os alicerces de nossa seqüência didática, que não podem ser modificadas, pois assim, corre-se o risco de descaracterizar o curso.

Um curso é formando, então, de atividades-estruturantes, que é a parte rígida do curso, e das demais atividades, a parte maleável, flexível. As modificações podem ocorrer nos últimos sem romper com os objetivos do curso. Fazendo uma analogia com uma casa, podemos pensar que os marcadores-estruturantes são como colunas que 
alicerçam a casa. Uma modificação na casa pode ser feita desde que esses pontos permaneçam praticamente intocáveis. No contrário, a estrutura da casa ficaria comprometida. Já a parte flexível do curso, seria análogo as paredes que fazem a divisões dos cômodos da casa, podem ser alteradas sem correr o risco da casa desabar.

Assim, temos os marcadores-estruturantes que são atividades que acreditamos serem essenciais para a estrutura do curso e juntamente a eles, as atividades que ajudam a lidar com a multidimensionalidade da sala de aula, como operacionalidade, avaliação, motivação e etc. São as atividades estruturantes juntamente com as demais atividades que confiam solidez, confiança e valor moral e biológico ao curso.

Sendo assim, buscamos definir os principais marcadores-estruturantes como os saberes necessários para estabelecer as ligações entre os tópicos (elementos) de nosso curso, atuando como pontos de intersecção.

A idéia de se ter na estrutura do curso uma parte "dura", uma parte que não pode ser modificada está ligada diretamente à Física, como saber de referência e uma outra parte flexível, que pode ser mudada, ligada ao sistema de ensino, onde se tem a figura do professor que faz as adaptações do conteúdo, levando em conta o projeto escolar e o aprendizado dos alunos.

Acreditamos que a parte dura do curso deva estar ligada à Física, porque essa parte deve obedecer a uma lógica do saber de referência que é a Física. Tendo seus conceitos centrais presentes na estrutura do curso para que assim, o Saber a Ensinar (curso) possa ser reconhecido pelo Saber Sábio (saber produzido na Física), como prevê a Transposição Didática. E ainda, a Física, como área de conhecimento científico, possui uma estrutura rígida contendo conceitos, definições e leis que regem os fenômenos naturais, formando as teorias, que possuem uma estrutura interna coerente.

Já a parte flexível do curso deve estar ligada ao sistema didático, porque assim, o professor poderá adequar as partes que são possíveis de serem modificadas para atender ao projeto escolar e a necessidade de seus alunos, objetivando a melhoria do ensino e do aprendizado do conteúdo por esses jovens. 
Apesar disso, não temos a pretensão de que este curso seja a única maneira possível de levar a Física de Partículas Elementares para o Ensino Médio, pois, contextos escolares diferentes, por exemplo, gerariam outras necessidades didáticas e poderiam, portanto determinar outros marcadores-estruturantes, que gerariam outro curso. Assim, a noção de marcadores-estruturantes permite diferenciar cursos que são diferentes na essência daqueles que apenas diferem na aparência.

Tendo em vista esses aspectos conseguimos definir os marcadores-estruturantes de nossa proposta. A atividade 1, envolve os Raios $\boldsymbol{X}$ que é o primeiro marcadorestruturante do curso. Assim, inicia-se a sequiência com a discussão sobre a descoberta dos raios $\mathrm{X}$ e da radioatividade, que foi crucial para desvendar a estrutura da matéria - o átomo. Apesar de outras investigações terem contribuído para a descoberta da estrutura atômica, foram as investigações e descobertas dos raios $\mathrm{X}$ e da radioatividade, que abriram as portas para o desenvolvimento de novas áreas da Física, como a Física Nuclear, Atômica e principalmente, a Física de Partículas.

Como conteúdo para o Ensino Médio, acreditamos que possa levar os alunos a um maior conhecimento sobre os processos de "criação", detecção, absorção e às principais aplicações das radiações, principalmente a dos raios $\mathrm{X}$, levando os alunos a compreender um pouco mais sobre esse objeto físico tão presente no seu dia-a-dia.

A necessidade de entender e compreender a produção dos raios $\mathrm{X}$ e da radioatividade levou a um maior interesse dos cientistas pela estrutura da matéria. Assim, a busca por uma explicação mais plausível para os raios $\mathrm{X}$ e as radiações, levanta questões para os alunos, fazendo com que busquem mais conhecimento sobre a estrutura da matéria. Desta forma, leva-se ao descobrimento do elétron e conseqüentemente, novos modelos atômicos são apresentados. Para tentar resolver um impasse existente entre dois modelos atômicos (Thomson e Nagaoka), surgem as investigações sobre a "verdadeira" estrutura do átomo, com Rutherford. Utilizando o espalhamento de partículas alfa, ele investiga a estrutura do átomo. Desta forma, vimos ser necessário um marcador-estruturante para discutir os modelos atômicos ${ }^{48}$. Então, definimos o segundo marcador com a atividade Espalhamento Rutherford.

\footnotetext{
${ }^{48}$ Essa é um aspecto importante para o desenvolvimento do curso, pois a Ciência utiliza modelos para tentar descrever a natureza que é investigada.
} 
Os modelos atômicos são marcadores-estruturantes importante no desenvolvimento do curso, porque além de tratar dos vários modelos atômicos desenvolvidos durante a história do pensamento da humanidade, ele traz consigo um caráter epistemológico. Isso, porque “os modelos desempenham um papel imprescindível na construção do conhecimento científico" (Brockington, 2005), sendo a essência do processo científico, pelo qual se pode apreender conceitualmente a realidade.

Com a discussão dos modelos atômicos e o descobrimento do núcleo e de novas partículas, como o próton e o nêutron, novas questões são apresentadas, mostrando que há inconsistências na descrição do modelo vigente (átomo de Bohr). Com isso, faz-se necessário um aprofundamento no estudo do núcleo atômico para responder as questões sobre a emissão de elétrons pelo núcleo e a natureza da radiação alfa.

Assim, passamos a estudar o núcleo atômico buscando entender a sua estabilidade, descobrindo duas novas interações: a força forte e a fraca. Com a discussão da interação forte, pode-se esclarecer melhor a natureza da radiação alfa, que já havia sido identificada anteriormente, no início do curso. Já através da discussão da interação fraca, pode-se compreender melhor a transmutação de alguns elementos, devido à emissão da radiação beta e da natureza dos elétrons emitidos pelos núcleos.

$\mathrm{Na}$ discussão sobre a interação forte, não obedecendo a uma sequiência cronológica, optamos por estudar a estrutura interna de algumas partículas, como os prótons e os nêutrons. Assim, definimos o nosso terceiro marcador-estruturante: estrutura das partículas.

Nesse marcador, buscamos mostrar que devido ao aparecimento de um número muito grande de partículas, como conseqüência do desenvolvimento dos aceleradores de partículas e as investigações dos raios cósmicos, houve uma suspeita de que a natureza poderia se apresentar de uma forma mais simples, através de uma quantidade de partículas menores, ou seja, a natureza não seria tão diversificada em sua estrutura mais elementar. Sendo corroborado pela descoberta do méson pi, por um grupo de cientistas, do qual César Lattes fazia parte. 
Discutimos os quarks, os glúons e o mecanismo da interação forte e, posteriormente, a força fraca. Com isso, mostramos de uma maneira mais detalhada, o processo do decaimento beta, que na verdade ocorre na "transformação" de um nêutron em um próton com a emissão de elétron e um neutrino. Além disso, algumas características que são peculiares aos quarks, como a carga cor e o confinamento, são discutidas com os alunos nessa atividade.

Como conteúdo para o Ensino Médio, essa atividade apresenta para os alunos uma nova interação da natureza, explicando de forma plausível a estabilidade do núcleo, rompendo com a concepção de que partículas de mesmo sinal somente sofrem repulsão. Além disso, derruba a concepção de que os constituintes do núcleo, dos prótons e dos nêutrons são partículas elementares.

Com a discussão das novas forças da natureza, com o aparecimento de um número muito grande de partículas e o desenvolvimento dos aceleradores de partículas, novos eventos com as partículas passam a ser observados. Assim, vê-se necessário novas leis de conservação para mostrar que alguns eventos podem ser observados e outros não. Com isso, conseguimos definir o marcador-estruturante seguinte: Leis de conservação.

Acreditamos que esse marcador é importante para a estrutura do curso porque levanta a questão da existência de alguns eventos e não de outros, mostrando um pouco do processo da criação de novas leis de conservação, podendo ser discutido, como novas leis de conservação são criadas através de análise de novos eventos das partículas elementares. Aqui se torna um momento propício para a discussão sobre simetria, uma vez que esse conceito está ligado diretamente à formulação de novas leis de conservação, tendo um papel central e de grande importância na Física de Partículas Elementares.

Seguindo a sequiência do curso, passamos pela descoberta do pósitron, levando a idéia de antimatéria, inclusive ao processo de criação e aniquilação das partículas. Esse é um aspecto que acreditamos ser importante para se trabalhar no Ensino Médio. Por tratar bem a mudança de paradigma sobre o conceito do vácuo e da relação íntima existente entre energia e matéria, através da equação $\mathrm{E}=\mathrm{m}_{0} \mathrm{c}^{2}$, mostrando a possibilidade de a energia ser "transformada" em matéria e vice-versa. 
Retomando novamente a discussão sobre as novas interações descobertas, que foram descritas através de um quantum mensageiro, buscamos fazer uma descrição análoga para as interações conhecidas, a eletromagnética e a gravitacional. Assim, buscamos mostrar aos alunos uma descrição quântica dos campos responsáveis pelas interações, dando ênfase para os mensageiros de cada interação. Destacando que esses mensageiros formam um grupo de partículas chamadas "bósons". A nosso ver, trata-se de um dos aspectos mais importantes das descrições da Física de Partículas, uma vez que há uma mudança na descrição do campo e por isso, definimos um marcadorestruturante para esse tópico: Mensageiros das interações.

Assim, com essa descrição quantizada das interações, os alunos passam a reconhecer uma outra maneira de interpretar os campos e ainda, aprendem que existem diferenças marcantes nas propriedades, que se diferenciam em dois grupos, formando as famílias das partículas. Desta forma, estaríamos rompendo com o modelo clássico da descrição dos campos.

Aproveitando a discussão feita sobre os mensageiros das interações, fechamos o curso através da separação das partículas pelo tipo de interações a que são sensíveis, mostrando que as interações nucleares podem separá-las em dois subgrupos, aquelas que "sentem" a interação forte - os quarks, e aquelas que "sentem" a interação fraca os léptons.

Para fechar a nossa proposta, levando em conta os objetivos traçados inicialmente, definimos o último marcador-estruturante: Modelo Padrão.

Desde o início, com o marcador Raios $\boldsymbol{X}$, encaminhamos as discussões e o desenvolvimento do curso para que o fechamento pudesse ser feito com o Modelo Padrão, fornecendo aos jovens a descrição da matéria mais aceita atualmente e acreditando que esta seja a forma de dar ao estudo da Física de Partículas um sentido e uma espécie de guia geral de entendimento.

Conseguimos assim, definir os marcadores-estruturantes de nossa proposta de ensino para a Física de Partículas: o início: Radiações (blocos I e II); pontos intermediários: Modelos atômicos (bloco III), Estrutura das partículas (blocos IV e V), 
Leis de conservação (blocos VI e VII), Mensageiros das interações (bloco VIII); e o fim: Modelo padrão (bloco IX).

\section{2 - A análise dos marcadores-estruturantes}

\section{Marcador-estruturante I: Raios X}

Essa é uma atividade que dá início aos estudos da Física de Partículas Elementares. Para atrair a atenção e a curiosidade dos jovens, buscamos iniciar com uma atividade que estivesse bem próxima deles e que pudesse de alguma forma, estar ligada ao seu cotidiano, buscando iniciar e encaminhar o curso através de uma análise fenomenológica, que é tão peculiar a Física de Partículas Elementares. Por isso, iniciamos com a atividade das radiografias. O objetivo dessa atividade é levar ao aluno a compreensão do processo de produção dos raios $\mathrm{X}$, das radiografias e das diferenças entre as tonalidades presentes nelas, como conseqüência da absorção de diferentes materiais de densidades distintas. Para isso procuramos fazer com que o aluno entenda a natureza dos raios $\mathrm{X}$, como ocorreu a sua descoberta, quais foram as conseqüências dela para o meio científico, bem como instigá-lo a buscar mais informações sobre a natureza da estrutura da matéria para compreender melhor os raios X.

\section{I.1 - Descrição da atividade}

$\mathrm{Na}$ primeira parte da atividade, são entregues aos alunos radiografias (que foi pedido, em um momento anterior a aula, que trouxessem) para que eles possam olhá-las e destacar algumas características, como forma, nitidez, partes do corpo a que pertence se podem identificar algum tipo de anomalia, fraturas e etc. Sendo feita uma primeira discussão em um grupo de aproximadamente 5 alunos.

Em seguida são levantadas, pelo professor, algumas questões que buscam nortear a discussão, como: qual a radiografia que mais chamou a atenção? Por quê? Por que existem regiões mais claras e mais escuras? Por que algumas radiografias apresentam nitidez melhor? Como são produzidas as radiografias? 
Essas questões serviram como motivação para iniciar a discussão sobre os raios $\mathrm{X}$ e as radiografias, tendo um grande retorno dos alunos que discutirem e expuseram suas opiniões e sensações sobre as radiografias. Contudo, não sabiam como eram produzidos os raios X e nem as radiografias. Para formalizar toda a discussão feita com os alunos, foi entregue o texto "Vendo através da pele: a descoberta dos raios X" para que eles pudessem ler a respeito do assunto e responder algumas questões que se encontravam no final do texto.
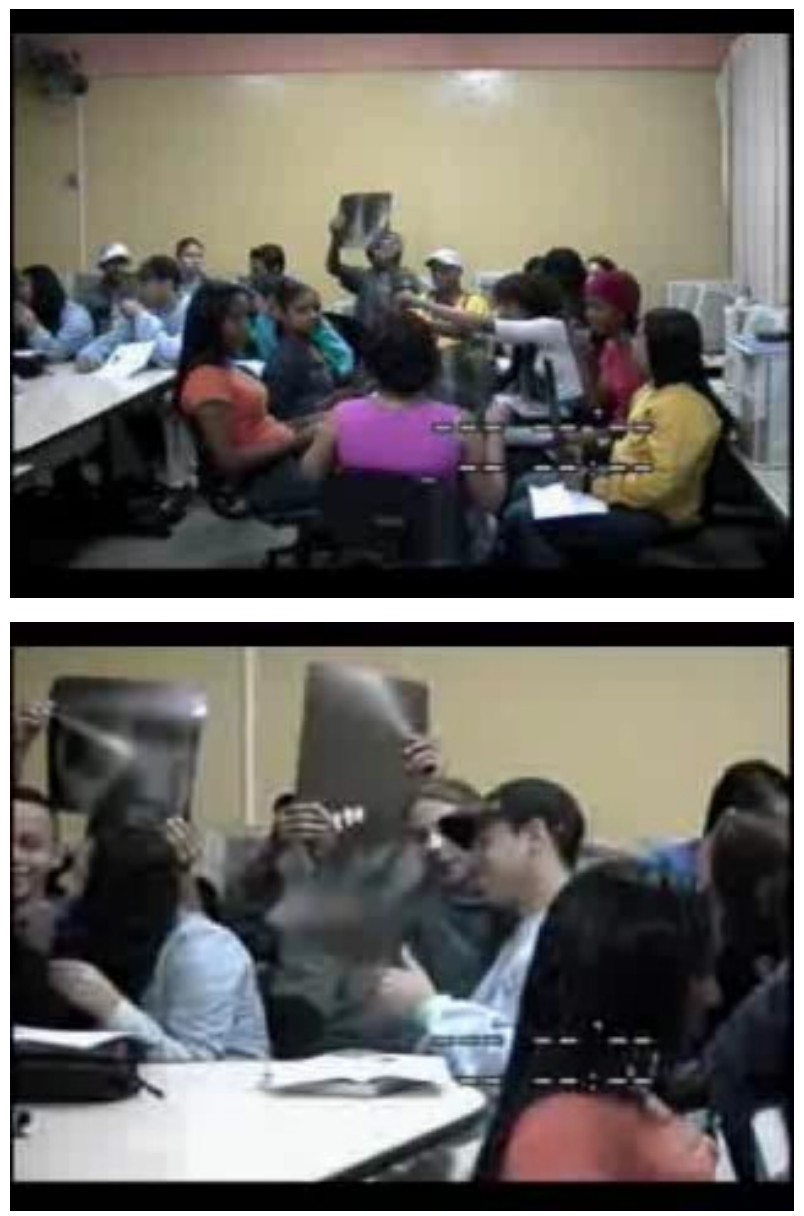


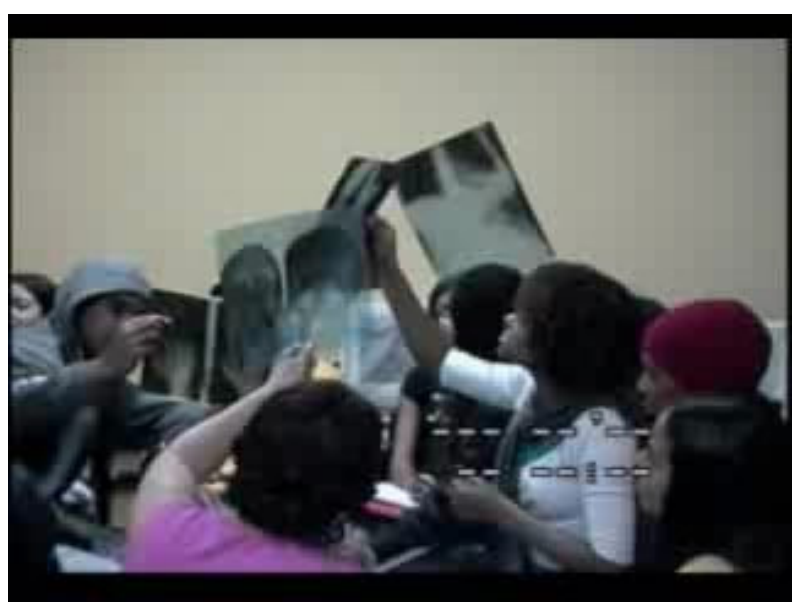

$\mathrm{Na}$ segunda parte da atividade, depois de conhecerem um pouco mais sobre o processo de produção dos raios X e da história de sua descoberta, é entregue a eles uma folha de papel fotográfico sensível à luz. Pedimos que colocassem sobre o papel objetos opacos, translúcidos ou transparentes de qualquer forma. Depois de permanecerem por aproximadamente 5 minutos próximos de uma fonte de luz, os objetos são retirados e nota-se a marca deixada por eles. Então duas questões são propostas: vocês podem distinguir bem as formas dos objetos? Nas marcas deixadas pelas formas no papel fotográfico, existe diferença quanto à nitidez (tonalidade)? Tente explicar essa diferença.

Essa segunda parte da atividade tem o objetivo de fazer uma analogia com a produção de radiografias, tendo a fonte de luz que sensibiliza o papel análoga à fonte de raios $\mathrm{X}$ e ao papel fotográfico, que é sensível a luz, e, a radiografia. Assim, buscamos visualizar e materializar a discussão feita na primeira parte, tentando levar o aluno a compreender melhor os principais aspectos da produção dos raios X e das radiografias.

Desta forma, esta parte da atividade busca, através da analogia, criar um ambiente lúdico, tentando aproximar o aluno do fenômeno discutido na aula. 

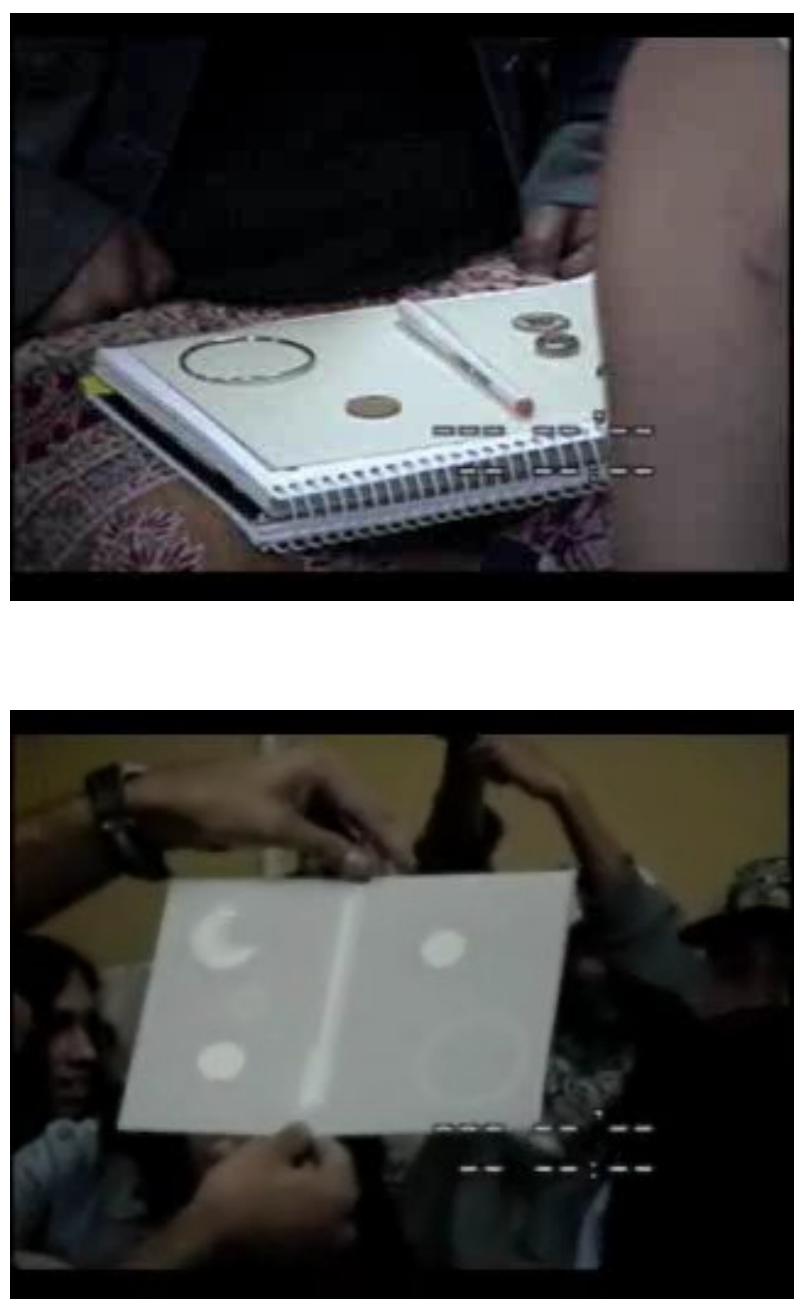

\section{I.2 - A análise}

Essa atividade teve como objetivo principal apresentar o processo dos raios X e o modo como ocorre à produção de chapas radiográficas; buscando, também salientar os principais aspectos referentes aos raios $\mathrm{X}$, como produção, detecção e absorção em alguns materiais. Não deixando de lado o aspecto histórico, que mostra como os raios X contribuíram para a mudança na concepção de átomo, para a evolução do modelo atômico e para o desenvolvimento de novas áreas na Física.

O desenvolvimento da atividade foi feito de forma aberta e dinâmica, deixando os alunos bem à vontade para que investigassem e discutissem as radiografias, gerando um 
grande interesse e entusiasmo entre eles em trabalhar um objeto tão próximo (por estar presente no cotidiano), mas ao mesmo tão distante de ser compreendido.

Assim, conseguimos notar que o ambiente da aula foi tranqüilo e envolvente, não havendo problemas com disciplina ou apatia dos alunos durante o transcorrer da aula. Esses, foram aspectos marcantes na aula, em momento algum notamos que os alunos estavam focados em outras coisas que não fosse a atividade. Todos os 31 alunos participaram ativamente da "análise" das radiografias, procurando identificar as questões que o professor havia proposto no início da atividade.

\begin{tabular}{|c|l|l|}
\hline Tempo & \multicolumn{1}{|c|}{ Transcrição } & Gestos \\
\hline $\mathbf{V}($ Prof) & "Vocês vão anotar os aspectos que vocês & \\
$\mathbf{1} \mathbf{1 0 "}$ & $\begin{array}{l}\text { acharem interessantes e que chamarem à } \\
\text { atenção de vocês.” }\end{array}$ & \\
\hline
\end{tabular}

Esse foi o primeiro ponto que forneceu indício da operacionalidade de nosso marcador. Como foi discutido no capítulo 4 (página 74), a operacionalidade está ligada diretamente a capacidade que o novo saber tem em gerar algum tipo de questão ou tarefa que possa ser avaliado pelo professor e que busque a conceituação do saber. Assim a questão proposta pelo professor teve o intuito de gerar uma tarefa para os alunos, para que ele posteriormente fizesse uma conceituação formal do saber que estava sendo discutido na atividade.

A manipulação das radiografias também foi o ponto alto da atividade. Ela durou cerca de 21 minutos, dentro do tempo previsto no planejamento da aula. Além disso, os alunos não mostraram qualquer dificuldade em manuseá-las, fazendo de maneira correta, levantando-as em direção à luz para realçar bem as diferenças de tonalidades. Durante a análise das radiografias, os alunos conseguiram identificar objetos diferentes, como um aparelho ortodôntico presente em uma delas, como mostra o diálogo a seguir ${ }^{49}$ :

\footnotetext{
${ }^{49}$ Iremos utilizar a seguinte notação para as falas dos alunos: $\mathbf{V}$ representa que a transcrição é de vídeo, $\mathbf{Q}$ representa transcrição do questionário, A representa aluno e $\mathbf{x}$ o aparecimento do aluno na filmagem,
} 


\begin{tabular}{|c|c|l|}
\hline Tempo & Transcrição & \multicolumn{2}{|c|}{ Gestos } \\
\hline $\mathbf{V}\left(\mathbf{A}_{1}\right):$ & "olha essa aqui, parece que tem & Aponta com o dedo na \\
& um aparelho nos dentes dessa pessoa." & \\
\hline $\mathbf{V}\left(\mathbf{A}_{2}\right):$ & "onde?" & Aponta a região onde \\
\hline $\mathbf{V}\left(\mathbf{A}_{1}\right):$ & "aqui, não está vendo?" & aparece na radiografia \\
\hline $\mathbf{V}\left(\mathbf{A}_{2}\right):$ & "é mesmo, tem aparelho em cima e & \\
& em baixo." & \\
\hline
\end{tabular}

Em outro momento, notamos mais uma discussão gerada pelo manuseio das radiografias entre alunos de outro grupo. Mostrando o grande interesse despertado e o empenho deles em observar e discutir com os colegas os detalhes de cada radiografia, tentando fazer, de certa forma, um diagnóstico do problema apresentado pela pessoa na radiografia dela.

\begin{tabular}{|c|c|c|}
\hline Tempo & Transcrição & Gestos \\
\hline $\begin{array}{l}\mathrm{V}\left(\mathrm{A}_{3}\right) \\
23^{\prime} 10^{\prime \prime}\end{array}$ & “olha! A mão tem um problema." & \\
\hline $\begin{array}{l}\mathrm{V}\left(\mathrm{A}_{4}\right) \\
23^{\prime} 13^{\prime \prime}\end{array}$ & "é... parece que é torta." & \\
\hline $\begin{array}{l}\mathrm{V}\left(\mathrm{A}_{5}\right) \\
23^{\prime} 17^{\prime \prime}\end{array}$ & $\begin{array}{l}\text { “a radiografia pode ter sido tirada } \\
\text { de lado, vocês não acham?” }\end{array}$ & \\
\hline $\begin{array}{l}\mathrm{V}\left(\mathrm{A}_{4}\right) \\
23^{\prime} 22^{\prime \prime}\end{array}$ & "é, talvez." & \\
\hline $\begin{array}{l}\mathrm{V}\left(\mathrm{A}_{3}\right) \\
23^{\prime} 30^{\prime \prime}\end{array}$ & $\begin{array}{l}\text { "mas olha essa, é a mesma mão. } \\
\text { Acho que a mão da pessoa é torta } \\
\text { mesmo." }\end{array}$ & \\
\hline $\mathbf{V}\left(\mathbf{A}_{4}\right)$ & "Deixa eu ver. Acho que é mesmo. & \\
\hline
\end{tabular}

conforme aparecem, recebem um número. Já o questionário, eles receberam letras do alfabeto, em uma ordem aleatória. 


\begin{tabular}{|l|l|}
\hline $\mathbf{2 3}^{\prime 3} \mathbf{3 5}^{\prime \prime}$ & $\begin{array}{l}\text { Não foi a radiografia que foi tirada } \\
\text { errada, não. A pessoa tem um problema } \\
\text { no dedo. Olha como está torto nessa } \\
\text { também?” }\end{array}$ \\
\hline
\end{tabular}

Alguns alunos foram além do que identificar objetos presentes nas radiografias. Eles analisaram duas radiografias da parte da cintura de pessoas distintas. Mesmo sem identificação nenhuma nas radiografias, eles concluíram que uma deveria ser de homem e a outra de mulher. Quando questionado porque eles haviam chegando àquela conclusão, explicaram:

\begin{tabular}{|c|l|l|}
\hline Tempo & \multicolumn{1}{|c|}{ Transcrição } & \multicolumn{1}{|c|}{ Gestos } \\
\hline $\mathbf{V}\left(\mathbf{A}_{\mathbf{8}}\right)$ & \multicolumn{1}{|c|}{ "A radiografia da mulher tem a } & Ele mostra com a mão, \\
$\mathbf{1 0}^{\prime} \mathbf{4 5} "$ & parte do quadril (bacia) mais distante do & indicando as distâncias \\
& que a outra, que provavelmente é de um \\
& homem.” & $\begin{array}{l}\text { entre os ossos do quadril, } \\
\text { nas duas radiografias. }\end{array}$ \\
\hline
\end{tabular}

Para encaminhar todo o desenvolvimento dessa atividade, foi entregue, no início, um roteiro que serviu como guia para a atividade. Esse roteiro continha questões, que foram reforçadas pelo professor antes deles receberem as radiografias, fazendo que os alunos fossem guiados pelas perguntas para análise e discussões. Ao final do manuseio das radiografias, o professor buscou levantar novamente as questões para iniciar a discussão sobre os raios $\mathrm{X}$, como no trecho seguinte:

\begin{tabular}{|c|c|c|}
\hline Tempo & Transcrição & Gestos \\
\hline $\begin{array}{l}\text { V(Prof.) } \\
24^{\prime} 20^{\prime \prime}\end{array}$ & $\begin{array}{l}\text { "Quais são as coisas mais comuns } \\
\text { entre as radiografias? O que mais } \\
\text { chamou a atenção?" }\end{array}$ & \\
\hline $\begin{array}{l}\mathrm{V}\left(\mathrm{A}_{7}\right) \\
24^{\prime} 30^{\prime \prime}\end{array}$ & "ah... a diferença de tons nelas." & \\
\hline $\begin{array}{l}\text { V(Prof.) } \\
24^{\prime} 44^{\prime \prime}\end{array}$ & $\begin{array}{l}\text { "Quais são as tonalidades que } \\
\text { aprecem aí?" }\end{array}$ & \\
\hline
\end{tabular}




\begin{tabular}{|c|c|}
\hline $\begin{array}{l}V\left(A_{7}\right) \\
24^{\prime} 48^{\prime \prime}\end{array}$ & 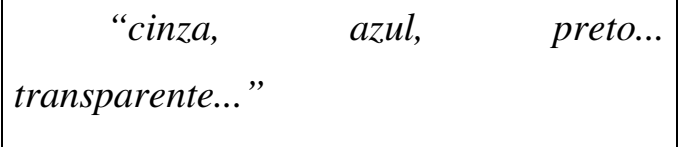 \\
\hline $\begin{array}{l}\text { V(Prof.) } \\
26^{\prime} 15^{\prime \prime}:\end{array}$ & $\begin{array}{l}\text { "Tem regiões que são mais claras, } \\
\text { tem regiões que são mais escuras. Como } \\
\text { é entre a parte da... Aparece aí... Vocês } \\
\text { conseguem visualizar parte do tecido, do } \\
\text { sangue, alguns órgãos, vocês conseguem } \\
\text { visualizar?" }\end{array}$ \\
\hline $\begin{array}{c}\text { V(alunos) } \\
2^{\prime} 45^{\prime \prime}\end{array}$ & "Tem pulmão, pedras nos rins..." \\
\hline $\begin{array}{l}\mathrm{V}\left(\mathrm{A}_{9}\right) \\
\mathbf{2 7}^{\prime} 12^{\prime \prime}\end{array}$ & $\begin{array}{l}\text { "Conseguimos visualizar os } \\
\text { dentes, os olhos, o aparelho..." }\end{array}$ \\
\hline
\end{tabular}

Isso indica que apesar de ter tido um interesse muito grande dos alunos pelas radiografias, chegando até a fazer análise delas, em nenhum momento as questões do roteiro foram deixadas de lado, reforçando o fato de que a atividade foi executada sem problemas pelos alunos.

Esses pontos que acabamos de apresentar sobre a atividade das radiografias, corroboram a operacionalidade, indicando que essa aula, com a atividade é aplicável em sala de aula, tendo sido validada pelos alunos que se interessaram e participaram muito. Isso mostrou, que foi possível criar uma atividade, elaborar questões acerca dos raios $\mathrm{X}$ e de fenômenos ligados a ele.

Notamos também, em vários momentos da aula, indícios da terapêutica, mostrando o relativo sucesso da atividade. Um desses momentos, foi indicado pelo sucesso que o professor obteve em gerenciar o desenvolvimento da atividade, mostrando que não teve problemas em manter a atenção dos alunos para o objetivo da aula, mesmo quando estava explicando o conteúdo, permanecendo, aproximadamente, 26 minutos, formalizando a discussão feita com a atividade, sem à turma se dispersar e a aula se tornar uma bagunça. 
Do ponto de vista do planejamento da aula e da atividade, tivemos outra manifestação da terapêutica. A aula havia sido planejada em três momentos: colocação de questões para guia a atividade; aplicação da atividade; fechamento com formalização. No transcorrer das aulas, conseguimos notar nitidamente esses três momentos ocorrendo, indicando o sucesso que obteve o professor.

\begin{tabular}{|c|c|c|}
\hline $\mathbf{1}^{\mathbf{0}}$ momento & $\mathbf{2}^{\mathbf{0}}$ momento & $\mathbf{3}^{\mathbf{0}}$ momento \\
\hline $\begin{array}{c}\text { Colocação das questões } \\
\text { guias }\end{array}$ & Aplicação da atividade & Discussão e Formalização \\
\hline $10 \mathrm{~min}$ & $40 \mathrm{~min}$ & $40 \mathrm{~min}$ \\
\hline
\end{tabular}

No planejamento estava previsto o tempo de desenvolvimento de toda a aula com a atividade que também nos forneceu indícios da terapêutica. A aula e a atividade haviam sido programadas para serem trabalhadas em duas aulas, totalizando aproximadamente 90 minutos. Durante a aplicação o professor soube gerenciar bem esse tempo, não deixando a aula nem muito corrida, nem muito lenta, gastando um pouco mais do que as duas aulas para fazer o fechamento da atividade. O que foi totalmente compreensível, pois houve um atraso de cerca de 15 minutos dos alunos para voltarem do intervalo e entrarem na sala de aula.

Temos assim uma indicação do relativo sucesso que essa atividade apresentou na sala de aula, levando, assim, à terapêutica. Isso refletiu muito sobre as discussões levantadas em sala de aula, mostrando que essa atividade pode permanecer em sala, pois ela motiva a discussão entre os alunos e também os instiga a buscar um conhecimento do tópico apresentado.

$\mathbf{Q}\left(\mathbf{A}_{\mathbf{L}}\right):$ "nós podemos ver muitas coisas diferentes e principalmente as radiografias que podemos discutir o que vemos de diferente com os colegas."

Para garantir o sucesso da atividade, será necessário, no entanto, outros resultados de pesquisa com aplicação em outras salas de aula. 
A segunda parte dessa atividade permitiu que fosse feita uma analogia dos papéis fotográficos com a produção e detecção dos raios X, uma vez que era impossível levar um aparelho de verdade para a sala de aula. Com isso, conseguimos melhorar o entendimento dos alunos sobre o objeto estudado, levando a criação de um objeto didático que auxiliou no aprendizado dos alunos. Esse fato configura a criatividade didática, inerente a todo processo de produção de saber escolar.

A transcrição abaixo evidência que a analogia teve sucesso em gerar entendimento. Pois como havíamos discutido, a criatividade didática implica em criar objetos didáticos que tem sua existência garantida somente na sala de aula, com o objetivo de auxiliar a aprendizagem do aluno.

\begin{tabular}{|c|c|c|}
\hline Tempo & Transcrição & Gestos \\
\hline $\begin{array}{l}\text { V(Prof.) } \\
57^{\prime} 50^{\prime \prime}\end{array}$ & $\begin{array}{l}\text { "Gente! No papel fotográfico, } \\
\text { quem é que está causando isso aqui?" }\end{array}$ & $\begin{array}{l}\text { (o professor mostra o papel } \\
\text { fotográfico de um dos } \\
\text { grupos, indicando as marcas } \\
\text { deixadas pelos objetos) }\end{array}$ \\
\hline $\begin{array}{l}\text { V(alunos) } \\
5^{\prime}\end{array}$ & “a luz!” & \\
\hline $\begin{array}{l}\text { V(Prof.) } \\
58^{\prime} 05^{\prime \prime}\end{array}$ & $\begin{array}{l}\text { "Porque está aparecendo essas } \\
\text { imagens aqui?" }\end{array}$ & $\begin{array}{llr}\text { Indica com } & \text { o } & \text { dedo as } \\
\text { imagens } & \text { no } & \text { papel } \\
\text { fotográfico. } & & \end{array}$ \\
\hline $\begin{array}{l}\text { V(alunos) } \\
58^{\prime} 10^{\prime \prime}\end{array}$ & “a luz!” & \\
\hline $\begin{array}{l}\text { V(Prof.) } \\
58^{\prime} 13^{\prime \prime}\end{array}$ & $\begin{array}{l}\text { "É uma onda eletromagnética que } \\
\text { está causando isso também. A mesma }\end{array}$ & \\
\hline
\end{tabular}




\begin{tabular}{|l|l|l|}
\hline & $\begin{array}{l}\text { onda que causou o aparecimento das } \\
\text { imagens nas radiografias. }\end{array}$ & \\
\hline
\end{tabular}

A criatividade didática permitiu fazer uma discussão acerca da produção, detecção e da absorção dos raios X sobre o corpo humano e outros objetos. Assim, conseguimos elaborar questões na própria atividade e conectá-las com ao texto que foi entregue em seguida (Vendo através da pele: a descoberta dos raios X) com o objetivo de dar uma maior formalização à discussão e, a partir daí, gerar novas questões para serem respondidas por eles.

Desta forma, vemos o grande potencial que esse tópico possui em criar questões (qualitativas) para a discussão e o entendimento dos raios $\mathrm{X}$, justificando assim sua presença na sala de aula, apresentando uma operacionalidade, agora no sentido da regra IV, ou seja, conseguindo transformar esse saber em exercícios e problemas (Regra IV). A própria atividade trouxe questões que puderam ser trabalhadas durante a aula com os alunos, como a questão seguinte, colocada pelo professor durante a discussão das radiografias:

\begin{tabular}{|c|c|c|}
\hline Tempo & Transcrição & Gestos \\
\hline V(Prof.) & "Vocês conseguem imaginar o & \\
\hline $\mathbf{2 9}$ & mundo hoje sem os raios X?" & \\
\hline $\mathbf{V ( P r o f . )}$ & "Aliás, a gente poderia ir até mais & \\
$\mathbf{2 9} \mathbf{2 1} "$ & $\begin{array}{l}\text { fundo. Será que a descoberta dos raios X } \\
\text { foi para fazer isso ou foi por algum outro } \\
\text { acidente totalmente ocasional?” }\end{array}$ & \\
\hline
\end{tabular}

Nesse momento, o professor faz uma ligação desta atividade com o texto de abordagem histórica, que seria entregue em seguida, para a formalização de toda a discussão sobre os raios $\mathrm{X}$. Houve um encadeamento da atividade com os textos produzidos no curso. 
Isso, nos leva a concluir que essa segunda parte da atividade auxiliou, os alunos a compreenderem melhor o processo de produção e detecção dos raios X através das chapas radiográficas, mostrando que esse marcador apresenta uma regra essencial no processo da Transposição Didática que é tornar um conceito mais compreensível (Regra V). Assim, conseguimos por meio de uma analogia, uma forma mais "clara" dos alunos entenderem os raios $\mathrm{X}$.

Do ponto de vista escolar e do currículo de Física, a discussão sobre os raios X se faz necessária, uma vez que esse ente físico está no cotidiano das pessoas, mas elas não o conhecem bem. Assim sendo, a escola torna-se um meio de acesso, no qual, os jovens podem ter um conhecimento maior sobre os aspectos dos raios $\mathrm{X}$, eliminando mitos $\mathrm{e}$ crendices, erguendo um conhecimento mais sólido e com explicações menos distorcidas pelo saber popular. Assim justifica-se sua presença em sala de aula por trazer uma atualização moral, por se tratar de um tópico importante a ser discutido em sala de aula e presente no currículo de Física do Ensino Médio, levando assim a uma atualização do saber escolar (Regra II).

Obtemos indícios dessas características no questionário aplicado ao final do curso, ao perguntar aos alunos qual foi a atividade que mais tinham gostado e por quê? As respostas de alguns alunos são descritas a seguir:

$\mathbf{Q}\left(\mathbf{A}_{\mathbf{B}}\right):$ "Porque esses temas são algo que muitas pessoas acham incrível, $e$ também porque o raio X é algo muito útil ao homem."

$\mathbf{Q}\left(\mathbf{A}_{\mathbf{J}}\right):$ "É interessante para aprender o que é perigoso."

$\mathbf{Q}\left(\mathbf{A}_{\mathbf{M}}\right):$ "Achei interessante estudar e compreender melhor sobre algo tão “conhecido", como o raio $X$, tão utilizado por todos."

Conseguimos, ao discutir aspectos ligados à produção, detecção e absorção dos raios $\mathrm{X}$, fazer uma conexão com um conhecimento que já está presente em sala de aula, o requisitado para dar uma melhor explicação da natureza dos raios X. Esse foi o caso da radiação eletromagnética ou ondas eletromagnéticas. Assim, conseguimos articular o saber novo com o antigo (Regra III), dando uma maior credibilidade para esse novo 
saber, pois como destaca Astolfi (1997) alguns conteúdos são escolhidos "porque permitem uma articulação mais satisfatória entre o novo que se tenta introduzir, e o velho já provado no sistema (...)”. Esse aspecto pode ser visto na transcrição a seguir:

\begin{tabular}{|c|c|c|}
\hline Tempo & Transcrição & Gestos \\
\hline $\begin{array}{l}\text { V(Prof.) } \\
39^{\prime} 50^{\prime \prime}\end{array}$ & $\begin{array}{l}\text { "Porque não se consegue enxergar } \\
\text { os raios X?" }\end{array}$ & \\
\hline $\begin{array}{l}\text { V(Prof.) } \\
40^{\prime} 18^{\prime \prime}\end{array}$ & $\begin{array}{l}\text { "Por que você não consegue enxergar o } \\
\text { raio X e por que você enxerga a luz? } \\
\text { Qual a característica do raio X que faz } \\
\text { com você não enxergue ele? }\end{array}$ & \\
\hline $\begin{array}{l}\mathrm{V}\left(\mathrm{A}_{6}\right) \\
41^{\prime} 06^{\prime \prime}\end{array}$ & $\begin{array}{l}\text { "a gente só consegue ver ela com } \\
\text { outro magnetismo de luz." (mostra uma } \\
\text { radiografia). }\end{array}$ & \\
\hline $\begin{array}{l}\mathrm{V}\left(\mathrm{A}_{8}\right) \\
4^{\prime}\end{array}$ & $\begin{array}{l}\text { "ah... acho que tem a ver com a } \\
\text { velocidade." }\end{array}$ & \\
\hline $\begin{array}{l}\text { V(Prof.) } \\
44^{\prime} 06^{\prime \prime}\end{array}$ & $\begin{array}{l}\text { "Velocidade não seria o termo } \\
\text { mais adequado, mas acho que todo } \\
\text { mundo deve lembrar de algo que foi } \\
\text { discutido em sala de aula, que é a } \\
\text { freqüência." }\end{array}$ & \\
\hline
\end{tabular}

Depois de os alunos terem respondido o questionário (Anexo) que elaboramos para tentar levantar algumas de suas impressões sobre as atividades e a estrutura do curso, confirmamos o que já havíamos percebido na gravação da aula sobre essa atividade. Notamos que eles ficaram entusiasmados e participaram muito da atividade $\mathrm{e}$ que havíamos acertado ao introduzir o curso com esse tipo de atividade. 
Essas respostas dos alunos reforçam ainda mais a terapêutica e a operacionalidade, indicando que essa atividade teve um relativo sucesso entre eles, alcançando o objetivo pré-determinado e que dessa forma, pode estar presente na sala aula.

\section{Marcador-estruturante II - Espalhamento Rutherford}

Essa atividade tinha o intuito de levar aos estudantes a discussão dos modelos atômicos e do próprio papel do modelo na ciência. Esse assunto que é raramente tratado nos livros didáticos e nos currículos do Ensino Médio das escolas no Brasil. Para tratar esse assunto, buscamos elaborar uma atividade que levasse, através de uma metáfora, ao experimento feito por Rutherford - O espalhamento de partículas alfa.

Com essa atividade foi possível discutir a questão de como "enxergar" um objeto que não pode ser visto a olho nu, devido ao seu tamanho, como é o caso das partículas e do núcleo atômico. Foi possível também discutir o uso de modelo para descrever aquilo que não temos acesso diretamente, sabendo se é exatamente aquilo que estamos descrevendo.

Além disso, essa analogia nos permitiu discutir a maneira como são feitas as experiências que indicam como é, aproximadamente, a estrutura do átomo e como ter "certeza" disso. Esse método (espalhamento de partículas) auxiliou na descoberta da estrutura interna das partículas com a presença dos quarks.

\section{II.1 - Descrição da atividade}

Os alunos têm várias placas de madeira com formas geométricas básicas (aproximadamente seis formas geométricas) feitas de isopor, coladas em baixo delas. Cada placa corresponde a uma forma geométrica. Essas placas permanecem sobre as mesas, para que as formas geométricas não possam ser vistas.

Os alunos, então, começam a sondar as formas, utilizando bolinhas de gude, que são lançadas para determinar as formas que estão coladas em baixo das placas. Para 
isso, eles levam em consideração o princípio da reflexão (o ângulo de incidência e igual ao ângulo de reflexão), traçando a trajetória das bolinhas na incidência e na reflexão. Os alunos começam então, a delinear as formas que estão abaixo das placas. Depois de certo número de incidências, eles tentam desenhar as formas que estão sob as placas.

Depois de fazer essa investigação sobre as formas que estão sob as placas, os alunos respondem a três questões presentes no roteiro: você pode determinar o tamanho e a forma do objeto? Como poderia saber se as figuras têm detalhes em sua forma, que são pequenos comparados com os tamanhos das bolinhas? Como você pode confirmar suas conclusões sem olhar os objetos?

Com essas questões, iniciamos a discussão sobre os objetivos da atividade, tentando levar os alunos a uma compreensão de como são feitas às investigações sobre o átomo, de como o desenvolvimento dos aceleradores de partículas permitiu fazer investigações cada vez mais detalhadas sobre o átomo e das próprias partículas. O ponto central da atividade está focado na resposta da última questão, quando temos a oportunidade de discutir a idéia de modelos, dando exemplos dos modelos atômicos utilizados nos livros de química e física do Ensino Médio.

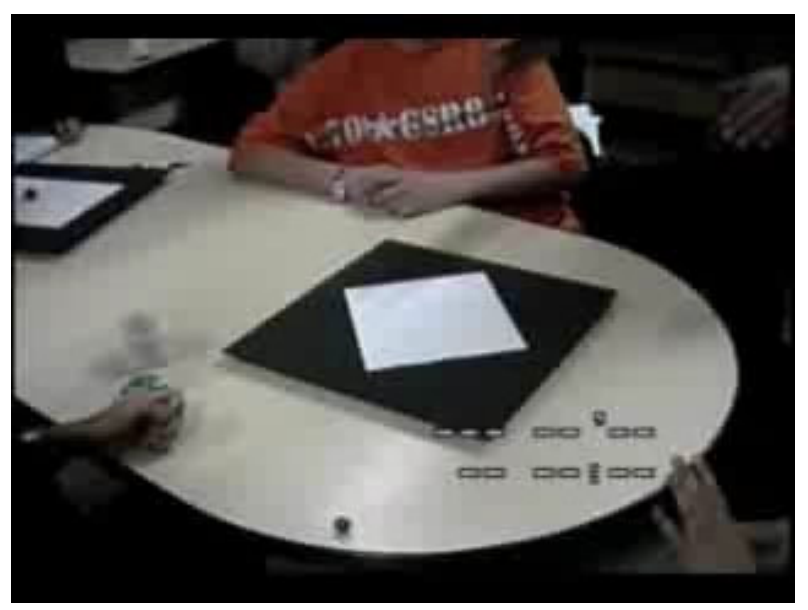




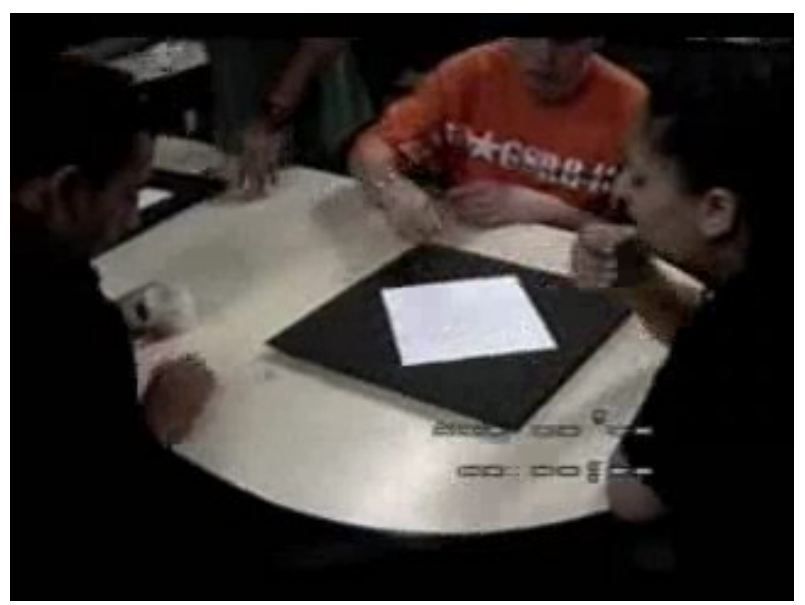

\section{II.2 - A análise}

Através de uma metáfora da experiência feita por Rutherford para descobrir o núcleo atômico, levamos os alunos a compreender o método de investigação muito utilizado na Física de Partículas Elementares. Esse é o experimento do espalhamento.

Desta forma, pedimos a eles para identificar as formas sob as placas, sem a possibilidade de olhá-las, utilizando somente bolinhas. Esse desafio lançado foi aceito pelos alunos, que em momento algum, desistiram de identificar as figuras. Ao final, eles entenderam que o objetivo da metáfora era tentar descrever a maneira pela qual Rutherford conseguiu “enxergar” o núcleo atômico, sem vê-lo.

Conseguimos captar um trabalho de um grupo, mostrando o processo de investigação e criação da forma por três alunos de um mesmo grupo, que conseguiram chegar muito próximo da forma que havia abaixo da placa. Depois de terem lançado várias bolinhas, começaram a descrição da forma: 


\begin{tabular}{|c|c|c|}
\hline Tempo & Transcrição & Gestos \\
\hline $\begin{array}{l}\mathrm{V}\left(\mathrm{A}_{1}\right) \\
29^{\prime} 22^{\prime \prime}\end{array}$ & $\begin{array}{l}\text { "O que dá para entender... ela é } \\
\text { ela é fechada assim sabe? Só em } \\
\text { algumas partes que ela passa no meio... } \\
\text { e aqui oh, ela é reta só em algumas } \\
\text { partes, porque você vê que ela passa } \\
\text { aqui e vai para um lado, vai para o } \\
\text { outro. Bate e volta." }\end{array}$ & $\begin{array}{l}\text { (mostra a trajetória da } \\
\text { bolinha com o dedo) }\end{array}$ \\
\hline \multirow[t]{2}{*}{$\begin{array}{l}\mathrm{V}\left(\mathrm{A}_{2}\right) \\
29^{\prime} 32^{\prime \prime}\end{array}$} & $\begin{array}{l}\text { "Mas as partes que ela vai reta é } \\
\text { sempre as das beiradas, sempre nas } \\
\text { beiradas." }\end{array}$ & $\begin{array}{l}\text { Indica com o lápis as } \\
\text { partes que passam reta na } \\
\text { tábua }\end{array}$ \\
\hline & $\begin{array}{l}\text { "É um negócio quadrado. É assim } \\
\text { oh..." }\end{array}$ & $\begin{array}{l}\text { Ela mostra o tipo de } \\
\text { figura quadrada. }\end{array}$ \\
\hline $\begin{array}{l}\mathrm{V}\left(\mathrm{A}_{3}\right) \\
\mathbf{2 9} \mathbf{9}^{\prime} \mathbf{9}^{\prime \prime}\end{array}$ & $\begin{array}{l}\text { "Espere aí... vamos jogar aqui. } \\
\text { Aqui é fechado. Aqui ela bate e volta. } \\
\text { Tem algum lugar que é aberto." }\end{array}$ & \\
\hline $\begin{array}{l}\mathrm{V}\left(\mathrm{A}_{1}\right) \\
30^{\prime} 22^{\prime \prime}\end{array}$ & $\begin{array}{l}\text { "Oh... ela bate e volta aqui. Igual } \\
\text { uma bolinha de ping-pong." }\end{array}$ & \\
\hline \multirow[t]{2}{*}{$\begin{array}{l}\mathrm{V}\left(\mathrm{A}_{3}\right) \\
32^{\prime} 17^{\prime \prime}\end{array}$} & “Eu acho que ela é assim oh... & $\begin{array}{l}\text { Indicando que a figura } \\
\text { tem cantos arredondados. }\end{array}$ \\
\hline & $\begin{array}{l}\text { Porque se você olhar ela bate e } \\
\text { volta oposto... dá... dá... Se eu conseguir } \\
\text { fazer ela voltar, né?" }\end{array}$ & \\
\hline $\begin{array}{l}\mathrm{V}\left(\mathbf{A}_{2}\right) \\
32^{\prime} 27^{\prime \prime}\end{array}$ & $\begin{array}{l}\text { "Bate aqui na ponta, bate aqui na } \\
\text { ponta!" }\end{array}$ & $\begin{array}{l}\text { Indicando com o lápis } \\
\text { onde deve ser jogada a } \\
\text { bolinha. }\end{array}$ \\
\hline $\begin{array}{l}\mathrm{V}\left(\mathrm{A}_{1}\right) \\
32^{\prime} 33^{\prime \prime}\end{array}$ & "Oh... ela bate aqui." & $\begin{array}{l}\text { Indicando a trajetória da } \\
\text { bolinha com o dedo. }\end{array}$ \\
\hline
\end{tabular}




\begin{tabular}{|c|c|c|}
\hline $\begin{array}{l}\mathrm{V}\left(\mathrm{A}_{2}\right) \\
32^{\prime} 50^{\prime \prime}\end{array}$ & $\begin{array}{l}\text { "Eu acho que é redondo com um } \\
\text { buraco no meio." }\end{array}$ & \\
\hline $\begin{array}{l}\mathrm{V}\left(\mathrm{A}_{3}\right) \\
32^{\prime} 53^{\prime \prime}\end{array}$ & $\begin{array}{lll}\text { “Então, } & \text { redonda... } & \text { redonda } \\
\text { assim!" } & \end{array}$ & $\begin{array}{l}\text { Indicando a curva com } \\
\text { um furo no meio. }\end{array}$ \\
\hline $\begin{array}{l}\mathbf{V}\left(\mathbf{A}_{3}\right) \\
\mathbf{3 3}^{\prime}\end{array}$ & "Nossa! Que redondo o seu? & \\
\hline $\begin{array}{l}\mathrm{V}\left(\mathrm{A}_{2}\right) \\
33^{\prime} 03^{\prime \prime}\end{array}$ & $\begin{array}{l}\text { "Você falou que é redondo assim... } \\
\text { que nem a mesa." }\end{array}$ & $\begin{array}{l}\text { Indica a forma com a } \\
\text { mão. }\end{array}$ \\
\hline $\begin{array}{l}\mathrm{V}\left(\mathbf{A}_{3}\right) \\
33^{\prime} 09^{\prime \prime}\end{array}$ & $\begin{array}{l}\text { "É! Mas esse redondo aqui é } \\
\text { fechado... é aberto." }\end{array}$ & $\begin{array}{l}\text { Indicando as aberturas da } \\
\text { figura no centro. }\end{array}$ \\
\hline $\begin{array}{l}\mathrm{V}\left(\mathrm{A}_{1}\right) \\
33^{\prime} 14^{\prime \prime}\end{array}$ & “Apaga!” & \\
\hline $\begin{array}{l}\mathrm{V}\left(\mathrm{A}_{2}\right) \\
33^{\prime} 15^{\prime \prime}\end{array}$ & "Cadê uma borracha?" & $\begin{array}{l}\text { Indicando com a mão } \\
\text { onde deve ser apagado. }\end{array}$ \\
\hline $\begin{array}{l}\mathrm{V}\left(\mathrm{A}_{1}\right) \\
33^{\prime} 46^{\prime \prime}\end{array}$ & "Ele é aberto aqui também." & $\begin{array}{l}\text { Indicando onde é aberto } \\
\text { com a mão. }\end{array}$ \\
\hline $\begin{array}{l}\mathrm{V}\left(\mathrm{A}_{3}\right) \\
34^{\prime} 12^{\prime \prime}\end{array}$ & $\begin{array}{l}\text { "Ele é redondo assim... aberto } \\
\text { aqui, aqui e aqui... é isso!" }\end{array}$ & $\begin{array}{l}\text { Indica o redondo e as } \\
\text { aberturas com as mãos. }\end{array}$ \\
\hline $\begin{array}{l}\mathrm{V}\left(\mathrm{A}_{2}\right) \\
35^{\prime} 10^{\prime \prime}\end{array}$ & $\begin{array}{l}\text { "Professor... oh, aí a gente } \\
\text { descobriu, já." }\end{array}$ & \\
\hline
\end{tabular}


Os alunos fazem o desenho da figura e o professor pede para que expliquem como chegaram àquela figura.

\begin{tabular}{|c|c|c|}
\hline Tempo & Transcrição & Gestos \\
\hline $\begin{array}{l}\mathrm{V}\left(\mathrm{A}_{2}\right) \\
\mathbf{3 5 ^ { \prime }} \mathbf{3 0} \mathbf{0}^{\prime \prime}\end{array}$ & $\begin{array}{l}\text { "A gente viu que quando batia... } \\
\text { ela voltava, tipo... a gente sentiu que } \\
\text { tinha uma... isso aqui sabe? uma ponta. } \\
\text { Vimos que era uma coisa arredondada." }\end{array}$ & \\
\hline $\begin{array}{l}\mathrm{V}\left(\mathrm{A}_{2}\right) \\
35^{\prime} 40^{\prime \prime}\end{array}$ & $\begin{array}{l}\text { É... uma coisa meio arredondada e } \\
\text { aqui as bolinhas passaram direto e aqui } \\
\text { passaram direto. Então dava essa } \\
\text { figura." }\end{array}$ & $\begin{array}{l}\text { Indica com a mão onde as } \\
\text { bolinhas passam direto. }\end{array}$ \\
\hline $\begin{array}{l}\text { V(Prof.) } \\
35^{\prime} 45^{\prime \prime}\end{array}$ & "Dava essa figura?" & \\
\hline $\begin{array}{l}\mathrm{V}\left(\mathrm{A}_{1}\right) \\
35^{\prime} 47^{\prime \prime}\end{array}$ & $\begin{array}{l}\text { "Não é exatamente ela, mas uma } \\
\text { coisa do tipo." }\end{array}$ & \\
\hline $\begin{array}{l}\text { V(Prof.) } \\
35^{\prime} 50^{\prime \prime}\end{array}$ & $\begin{array}{l}\text { "Mas gente é... isso que você está } \\
\text { fazendo..." }\end{array}$ & \\
\hline $\begin{array}{l}\mathrm{V}\left(\mathrm{A}_{2}\right) \\
35^{\prime} \mathbf{5 3 ^ { \prime \prime }}\end{array}$ & $\begin{array}{l}\text { "Isso aqui é quando as bolinhas } \\
\text { batiam e voltavam... elas vinham aqui e } \\
\text { saiam, iam reto." }\end{array}$ & $\begin{array}{l}\text { Indicando a trajetória das } \\
\text { bolinhas. }\end{array}$ \\
\hline $\begin{array}{l}\text { V(Prof.) } \\
35^{\prime} 59^{\prime \prime}\end{array}$ & $\begin{array}{l}\text { "Aí vocês deduziram que devia ser } \\
\text { isso porque é uma explicação, porque é } \\
\text { uma coisa maciça que batia para } \\
\text { voltar.", }\end{array}$ & \\
\hline $\begin{array}{l}\mathrm{V}\left(\mathrm{A}_{2}\right) \\
36^{\prime} 01^{\prime \prime}\end{array}$ & $\begin{array}{l}\text { "Isso! E outra, nos deduzimos } \\
\text { também que era meio quadrado, não era } \\
\text { um círculo. Porque aqui passava reto... } \\
\text { aqui passou reto... aqui passou reto." }\end{array}$ & $\begin{array}{l}\text { Indicando todas as } \\
\text { trajetórias com a mão. }\end{array}$ \\
\hline $\begin{array}{l}\text { V(Prof.) } \\
36^{\prime} 17^{\prime \prime}\end{array}$ & "Tá ok!” & \\
\hline
\end{tabular}


Com essa atividade, conseguimos criar um ambiente propício para discussão dos modelos atômicos, tão mostrado nas aulas de Química e algumas vezes nas aulas de eletrostática na Física. Porém, o foco da discussão é bem diferente, tendo o objetivo de discutir a evolução do conceito de átomo, passando pelos modelos atômicos.

Desta forma, conseguimos articular esse saber novo com o antigo (Regra III), indo além do que é feito normalmente nas salas de aula com esse conteúdo.

Esse foi um dos primeiros indícios de que havíamos conseguido obter algum resultado através da atividade proposta, atingindo, mesmo que parcialmente, o objetivo dessa atividade com os alunos.

Contudo, para auxiliar o desenrolar da atividade, foi entregue um roteiro, com questões que ajudavam a guiar os alunos durante a aplicação, com o intuito de levá-los a atingir o objetivo proposto. Notamos que em momento algum, eles deixaram as questões do roteiro fora de foco, mostrando que foi importante o uso do roteiro em uma atividade inovadora com conteúdo de Física de Partículas Elementares. Esse aspecto também pôde ser constatando no final da atividade, quando o professor retomou as questões para iniciar as discussões acerca das descrições das formas, do uso de modelos na Ciência e a necessidade de equipamentos mais sofisticados para investigações cada vez mais detalhadas sobre os constituintes da matéria. Assim, podemos concluir que tudo aquilo que o professor havia pedido no início da atividade, foi executado pelos alunos, que não apresentaram nenhum problema para desenvolvê-la.

Um outro aspecto que se destacou durante as filmagens das aulas, foi a visível aplicabilidade da atividade. Apesar de termos tido poucos alunos nesse dia, devido a comemorações na escola, foi nítido que todos os presentes compreenderam de forma satsifatória, participaram bastante e souberam desenvolver a atividade, sem maiores dúvidas e problemas. O professor, considerou a participação e o interesse dos alunos muito bom e os próprios alunos notaram esses aspectos. Conseguimos obter dos alunos algumas respostas dos alunos que seguem abaixo, a partir da pergunta feita no questionário aplicado: "Sobre a atividade do espalhamento você percebeu qual era o objetivo desta atividade?" 
$\mathbf{Q}\left(\mathbf{A}_{\mathbf{D}}\right):$ "com a atividade que fizemos em sala de aula, vimos com mais clareza como Rutherford fez para descobrir as radiações existentes.”

$\mathbf{Q}\left(\mathbf{A}_{\mathbf{E}}\right)$ : "vimos a maneira como foi feita a experiência para descobrir o formato do átomo."

$\mathbf{Q}\left(\mathbf{A}_{\mathbf{M}}\right)$ : "Entender como Rutherford descobriu qual era a estrutura do átomo, usando os raios alfa."

A manipulação da atividade, mostrou estar ao alcance de todos os alunos, tendo grandes destrezas e habilidades para lançar bolinhas, traçar trajetórias e fazer inferências sobre as formas escondidas. Assim, os alunos não apresentaram nenhum obstáculo em manusear os objetos da atividade.

Até mesmo a própria execução da atividade foi satisfatória, tendo os alunos compreendido rapidamente a explicação do professor sobre a maneira de tentar encontrar a forma escondida sobre a placa, através do lançamento de bolinhas de gude, fazendo a inferência da forma utilizando o princípio da reflexão (ângulo de incidência igual ao de reflexão) para traçar as trajetórias das bolinhas.

Assim, notamos que durante todo o desenvolvimento da atividade, foi grande o empenho dos alunos, em seus grupos, para determinar a forma escondida. Esse empenho levou à discussão sobre as possíveis formas, que foi feita através do levantamento de hipóteses com base nas descrições das trajetórias anotadas por eles e a todo momento, eles testavam essas novas formas, aprimorando-as até chegarem a uma que acreditavam ser a mais provável. Ao final, constatamos, juntamente com os alunos, que as formas encontradas por eles, estavam bem próximas das verdadeiras formas ou eram exatamente iguais. Podemos ver as formas encontradas por alguns alunos logo abaixo: 

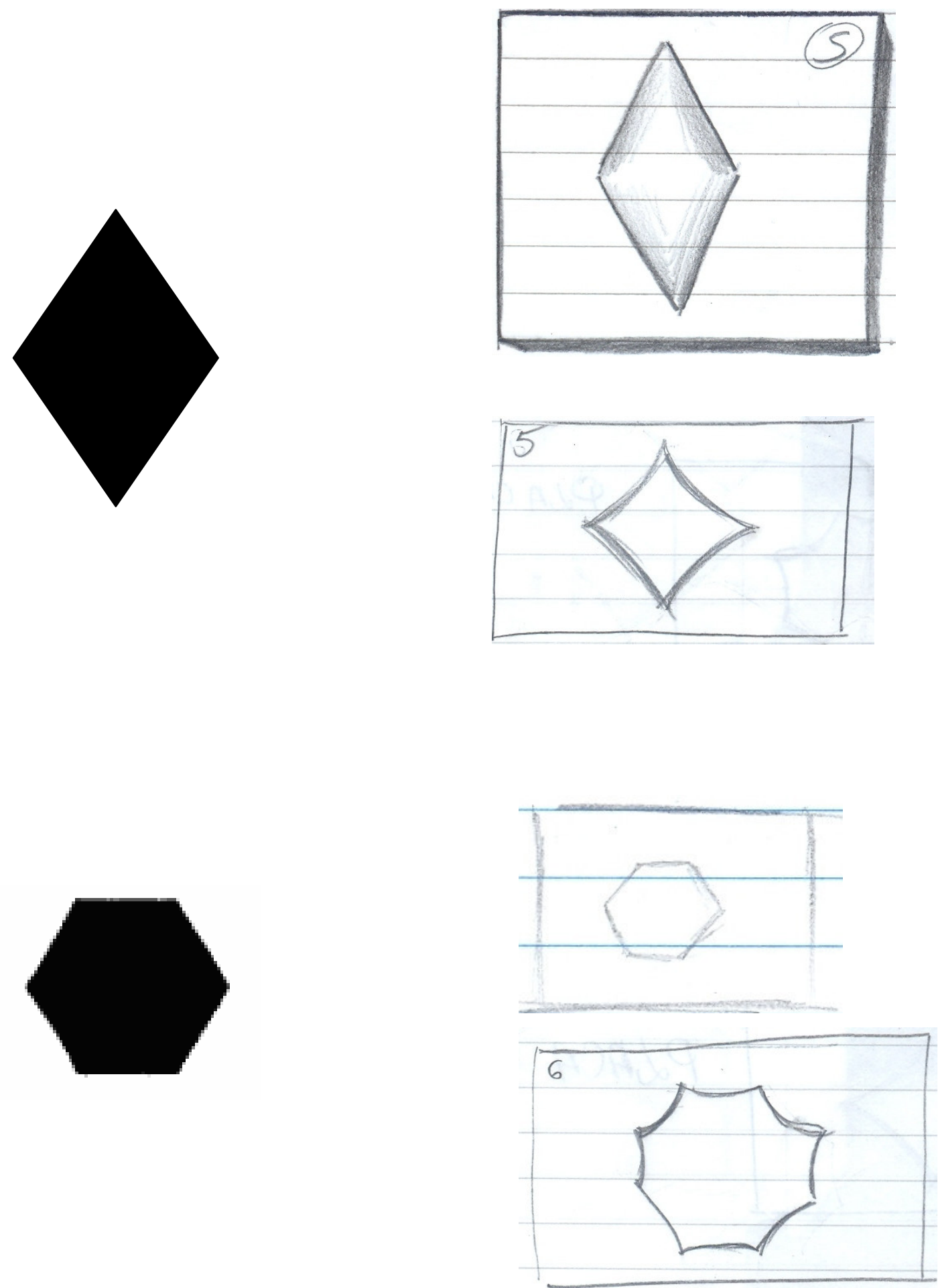
Esses aspectos destacados anteriormente, nos indicou um forte indício da operacionalidade, tanto da aula, quanto da atividade que se mostraram motivadoras e interessantes para os alunos, sendo possível ser executada por eles. Percebemos ainda, que durante os tempo de execução da atividade, 27 minutos e 30 segundos, os alunos não apresentaram nenhum tipo de desinteresse por ela, nem mesmo nos dois momentos que sucederam a aplicação da atividade, que foi o da discussão, aproximadamente 15 minutos, e da formalização, pelo professor, do conteúdo ligado à ela, que foi de 18 minutos e 40 segundos. Outro ponto nos chamou à atenção quanto ao interesse dos alunos pela aula, depois de ter tocado o sinal, eles permaneceram ainda por aproximadamente 20 minutos na sala de aula, atentos a explicação do professor sobre o conteúdo. Esse fato deve ser ressaltado, porque essas aulas ocorriam nas duas últimas aulas da sexta-feira do período noturno.

Essa atividade mostrou sua operacionalidade também no aspecto de criar questões, pois a partir de sua aplicação e desenvolvimento, o professor conseguiu formulá-las, buscando encaminhar a discussão para a introdução do texto "A descoberta de Rutherford: novo modelo atômico", que discute os modelos atômicos, mostrando o desenvolvimento da idéia de átomo.

Já do ponto de vista do professor, a atividade mostrou estar dentro da realidade dele (objetos familiares e de fácil acesso e manipulação), tanto de seu planejamento, quanto da sua aplicação, não tendo sido gasto o tempo que foi previsto. A aula e a atividade estavam previstas para serem feitas em 90 minutos, porém conseguimos constatar que foram gastos aproximadamente 60 minutos, restando tempo para a leitura do texto: A descoberta de Rutherford: um novo modelo atômico e para a discussão das questões presentes nele com os alunos. Isso foi um forte indício do relativo sucesso que a atividade obteve, mostrando a terapêutica presente nessa atividade.

Conseguimos iniciar as discussões sobre qual seria a verdadeira forma que estava escondida sob as placas a partir das análises feitas das maiorias das placas, pelos grupos presentes. Quando questionados qual seria a "verdadeira" forma por baixo de cada placa, eles notaram que havia grupos com descrições dos objetos bem parecidas, concluindo que a forma provavelmente seria aquela mostrada pelos grupos, ficando, de 
certa forma, satisfeitos com os resultados obtidos. As formas só foram mostradas ao final da aula.

No levantamento das hipóteses pelos alunos, vimos uma oportunidade de discutir mais sobre a Ciência e o fazer científico, criando um ambiente propício para manifestações de questões sobre a maneira que a Física ou a Ciência utiliza para exprimir a natureza sem enxergá-la diretamente, podendo levar à discussão da realidade dos objetos estudados na Física de Partículas Elementares e dos modelos em Ciência.

Essa atividade teve como objetivo fazer uma metáfora a partir de um dos principais métodos de investigação que a Física utiliza para sondar o mundo microscópico que é o espalhamento. Tivemos a oportunidade de mostrar como essa técnica foi desenvolvida por Rutherford para analisar a estrutura interna do átomo e assim, descobrir o seu núcleo. Essa técnica é utilizada até hoje e justifica a atualização biológica, que destaca que o conteúdo deve estar de acordo com a ciência vigente, mostrando que esse saber poderá servir para atualizar (Regra II) o currículo de Física presente na sala de aula.

Ao se discutir a questão 2 do roteiro (Como poderia saber se a figura tem detalhes em sua forma, que são pequenos em relação ao tamanho das bolinhas?), tivemos a oportunidade de aprofundar um pouco mais sobre as pesquisas em Física de Partículas, mostrando que para se ter uma descrição da estrutura da matéria, cada vez mais detalhada, é necessário aceleradores de partículas cada vez mais potentes. A metáfora aqui foi no sentido de mostrar que era fundamental bolinhas cada vez menores para descrever com mais riqueza os detalhes de cada figura. Assim, buscamos mostrar um pouco do desenvolvimento e da evolução dessa área da Ciência, permanecendo próximo do fazer científico, destacando mais uma vez a atualização biológica, como no trecho da descrição abaixo:

\begin{tabular}{|c|l|l|}
\hline Tempo & \multicolumn{1}{|c|}{ Transcrição } & Gestos \\
\hline $\mathbf{V}$ (Prof) & \multicolumn{1}{|c|}{ "quem tentou usar bolinhas } \\
$\mathbf{5 4}^{\prime 42 "}$ & $\begin{array}{l}\text { menores, pode ter conseguido observar } \\
\text { um efeito que não dava com a bolinha } \\
\text { maior." }\end{array}$ & \\
\hline
\end{tabular}




\begin{tabular}{|c|c|}
\hline $\begin{array}{l}\text { V(Prof) } \\
55^{\prime} 09^{\prime \prime}\end{array}$ & $\begin{array}{l}\text { "quem tentou só bolinhas } \\
\text { grandes... o efeito era um. Quem tentou } \\
\text { com bolinhas menores, os efeitos... já } \\
\text { conseguiram efeitos com mais detalhes, } \\
\text { porque usou um "instrumento" melhor." }\end{array}$ \\
\hline
\end{tabular}

E ainda, durante a explicação do conteúdo, foi nítido o encadeamento que o professor fez com outras aulas que já haviam ocorrido, mostrando assim, a estrutura interna que o curso possui.

Essa atividade, como metáfora do espalhamento Rutherford, pode ser considerado um objeto presente somente na sala aula, auxiliando o aprendizado desse novo saber, justificando dessa forma a criatividade didática. Além disso, como uma atividade prática, em que o aluno "põe à mão na massa", auxiliando o seu aprendizado. Esse tipo de atividade pode fazer com que o conceito seja mais palatável ao aluno, ou seja, tornar um conceito mais compreensível (Regra V) para o aluno, ficando assim mais próximo dele e talvez podendo ser compreendido melhor, conforme foi verificado nos questionários. Tendo desta maneira, um papel de destaque no curso.

\section{Marcador-estruturante III - Estrutura das Partículas}

Essa foi uma etapa que procuramos levar ao aluno uma visão mais detalhada da descrição de algumas partículas, mostrando que elas são constituídas de outras ainda menores, ou seja, algumas partículas apresentam uma estrutura interna. Essa nova descrição leva a queda do status de elementar do próton e do nêutron, partículas já estudadas anteriormente.

Para compreender essa nova visão das partículas e quais implicações geram para o estudo dessa área, procuramos levar uma atividade que tentasse, através de uma metáfora, descrever alguns problemas e uma visão dessa nova descrição das partículas. 


\section{III.1 - Descrição da atividade}

Nessa atividade, os alunos recebem figuras (triângulos e retângulos) feitas de cartolina branca. Na primeira parte, pedimos para eles formarem um próton e um nêutron, com duas dessas figuras, atribuindo valor para a carga e o spin de cada figura (deixamos bem claro que o valor atribuído para um retângulo é igual para todos, o mesmo ocorrendo com os triângulos). Lembramos, antes de iniciar a atividade, do princípio da exclusão de Pauli, através de exemplos e de que esse princípio deve ser obedecido na formação do próton e do nêutron, para que eles possam dessa forma distinguir o spin das partículas formadoras dos núcleons. Em seguida, pedimos para que se enuncie uma regra de formação, ou seja, quais os valores atribuídos aos retângulos e aos triângulos. No final, respondem a seguinte questão: os valores atribuídos obedecem ao princípio da exclusão de Pauli?

$\mathrm{Na}$ segunda parte, fazemos uma pequena modificação. Ao invés de usarem somente duas figuras, como na primeira parte, usam três, podendo repetir as formas. Seguem os mesmos processos da primeira parte. Ao final, enunciam a regra de formação, respondendo novamente a questão: os valores atribuídos obedecem ao princípio da exclusão de Pauli?

A partir dessa questão, inicia-se a discussão para eles tentarem propor uma hipótese para que o princípio da exclusão de Pauli não seja violado. Essa discussão culmina na proposta da carga cor, mostrando que um novo número quântico é necessário para que o princípio não seja mais violado.

Feito isso, retomamos a atividade, entregando a eles figuras coloridas (verde, vermelho e azul) para que agora possam formar novamente as suas partículas, indicando que o novo número quântico estende o princípio da exclusão de Pauli. Com isso verificamos se eles compreenderam ou não a discussão. 

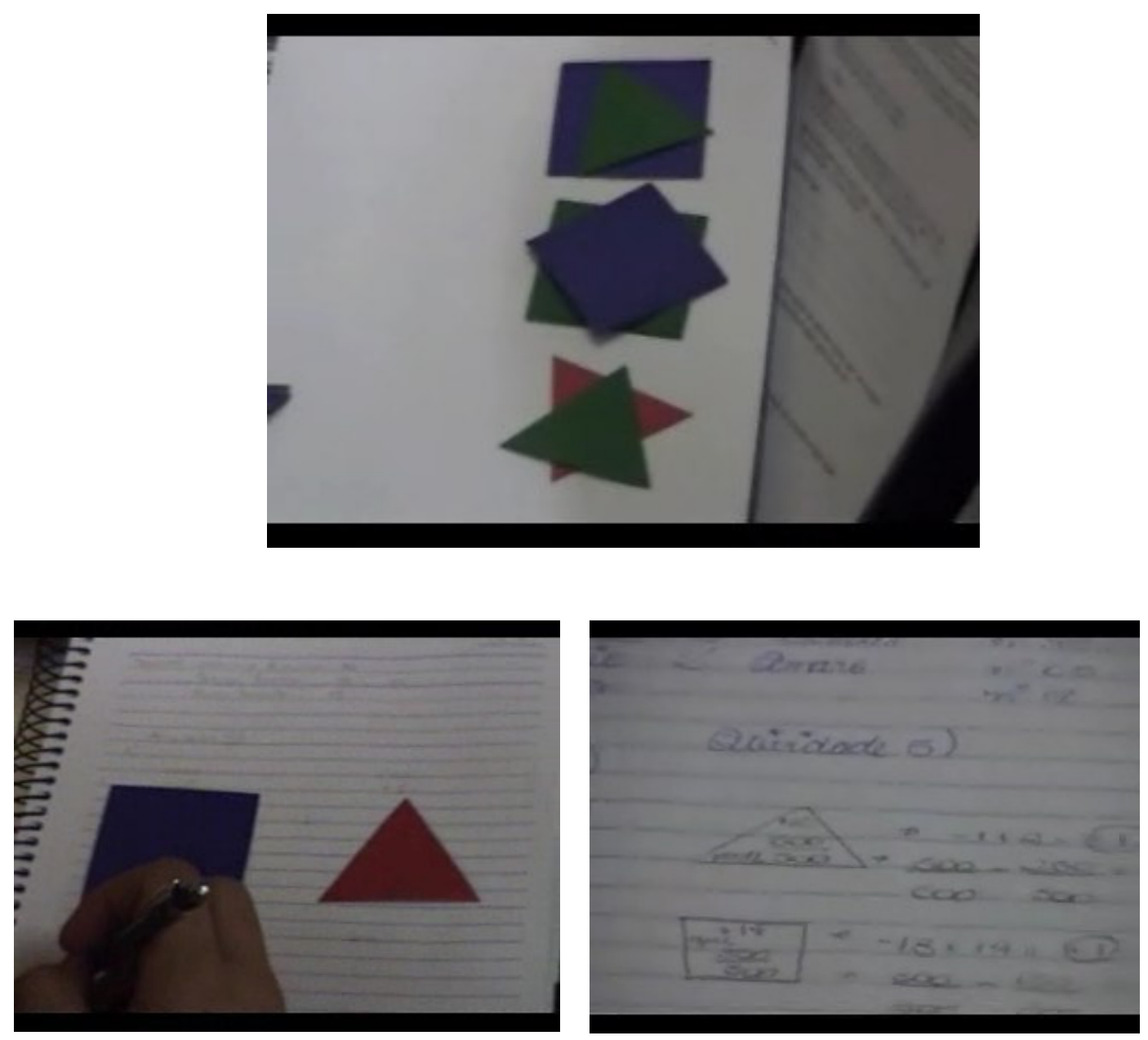

\section{III.2 - A análise}

A atividade, apresentada aos alunos, teve o caráter de metáfora, e o objetivo de mostrar que algumas partículas como o próton e o nêutron, são constituídas por partes menores, levando a perda do status de elementar dessas partículas.

Teve também o intuito de discutir a violação do princípio da exclusão de Pauli pelos quarks, sendo necessário atribuir um novo número quântico para essas novas partículas, que foi a carga cor, mostrando que somente o spin não era suficiente para obedecerem ao princípio da exclusão.

Desta forma, foi apresentado aos alunos o roteiro da atividade, guiando-os para o desenvolvimento dela, através de questões relacionadas com o objetivo. Antes, porém, o 
professor procurou esclarecer melhor o que deveria ser feito por eles durante a atividade.

A aula transcorreu conforme o esperado. O comportamento e o interesse da turma durante a explicação da atividade e o próprio desenvolvimento dela foram aspectos que nos chamaram à atenção, pois não houve nenhum tipo de tumulto, desatenção ou qualquer outro tipo de interesse que não fosse pela atividade.

Percebemos assim, que durante o desenrolar da atividade, todos os alunos em seus respectivos grupos, estavam empenhados na tentativa de encontrar uma solução para as questões propostas pela atividade.

Consideramos esses aspectos como os primeiros indícios da operacionalidade da atividade, pois conseguimos desenvolvê-la em aula, auxiliando a conceituação de um novo tópico da sequiência, como prevê a Transposição Didática. Podemos dizer, que os alunos conseguiram desenvolver o que foi proposto e souberam manipular os números para alcançar a resposta pretendida, ou seja, conseguiram atribuir valores para a carga e o spin de cada forma geométrica (representação das partículas), chegando à formulação de uma lei para formação de outra partícula, como era pedido no roteiro da atividade. Isso pode ser visto no trecho transcrito:

\begin{tabular}{|c|c|c|}
\hline Tempo & Transcrição & Gestos \\
\hline $\begin{array}{l}\mathrm{V}\left(\mathrm{A}_{1}\right) \\
19^{\prime} 57^{\prime \prime}\end{array}$ & "Tem que ser tudo fração?” & \\
\hline $\begin{array}{c}\mathrm{V}\left(\mathrm{A}_{2}\right) \\
19^{\prime} 59^{\prime \prime}\end{array}$ & "É, não sabe?!" & \\
\hline $\begin{array}{c}\mathrm{V}\left(\mathrm{A}_{1}\right) \\
20^{\prime}\end{array}$ & "Tem que dá um meio?” & \\
\hline $\begin{array}{c}\mathrm{V}\left(\mathrm{A}_{2}\right) \\
20^{\prime} 02^{\prime \prime}\end{array}$ & "É... Tem que dá meio." & \\
\hline
\end{tabular}




\begin{tabular}{|c|c|c|}
\hline $\begin{array}{l}\mathrm{V}\left(\mathrm{A}_{1}\right) \\
20^{\prime} 12^{\prime \prime}\end{array}$ & $\begin{array}{c}\text { "Então aqui vai ser: quatro } \\
\text { mais quatro, oito, menos sete, um." }\end{array}$ & $\begin{array}{l}\text { Indicando com o dedo os } \\
\text { valores na figura }\end{array}$ \\
\hline $\begin{array}{l}\mathrm{V}\left(\mathrm{A}_{2}\right) \\
20^{\prime} 15^{\prime \prime}\end{array}$ & "Vai dá um!" & \\
\hline $\begin{array}{l}\mathrm{V}\left(\mathrm{A}_{1}\right) \\
20^{\prime} 21^{\prime \prime}\end{array}$ & $\begin{array}{l}\text { "Mais vem cá! Hein oh, mas se } \\
\text { colocar dois... menos dois (-2) ou tem } \\
\text { que ser mais (+) aqui?" }\end{array}$ & $\begin{array}{l}\text { Indicando a figura do meio } \\
\text { com o dedo. }\end{array}$ \\
\hline $\begin{array}{l}\mathrm{V}\left(\mathrm{A}_{3}\right) \\
20^{\prime} 30^{\prime \prime}\end{array}$ & $\begin{array}{l}\text { "Não! Os triângulos têm que ser } \\
\text { iguais, tem que ser o mesmo. O } \\
\text { mesmo número." }\end{array}$ & \\
\hline $\begin{array}{l}\mathrm{V}\left(\mathrm{A}_{1}\right) \\
20^{\prime} 42^{\prime \prime}\end{array}$ & $\begin{array}{l}\text { "Ou..., que nem é possível, zero, } \\
\text { zero e meio. Pode ser? Pode ser? } \\
\text { Ou... aí deu certo." }\end{array}$ & $\begin{array}{l}\text { Mostrando com o dedo o } \\
\text { valor de cada figura. }\end{array}$ \\
\hline
\end{tabular}




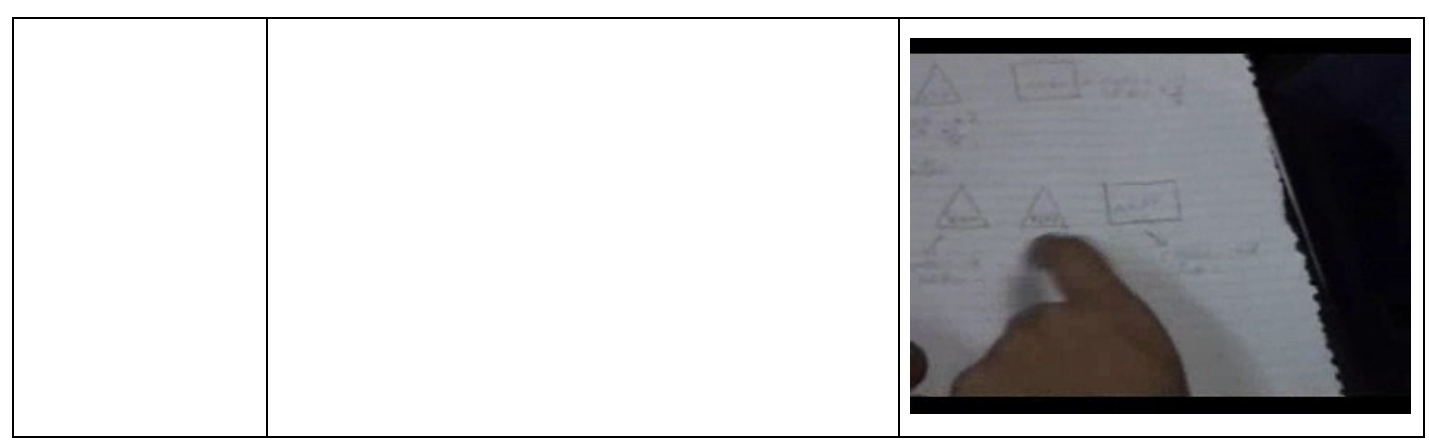

Apesar de não terem gostado tanto dessa atividade como gostaram das anteriores $^{50}$, um grande número de alunos responderam que haviam compreendido o objetivo da atividade. Isso levou-nos a concluir que a operacionalidade da atividade se manifestou durante o seu desenvolvimento. Conseguimos captar a impressão dos alunos através do questionário.

$\mathbf{Q}\left(\mathbf{A}_{\mathbf{E}}\right)$ : “ o objetivo da atividade foi mostrar que além de prótons, elétrons e nêutrons, há mais partículas ainda."

$\mathbf{Q}\left(\mathbf{A}_{\mathbf{F}}\right)$ : “ saber que a menor partículas existente é o quark..”

$\mathbf{Q}\left(\mathbf{A}_{\mathbf{L}}\right)$ : “percebi que a partir de uma só partícula pode-se existir várias outras partículas.”

$\mathbf{Q}\left(\mathbf{A}_{\mathbf{P}}\right)$ : “ que existem várias outras partículas como os píons.”

Já do ponto de vista do professor, conseguimos observar que, em nenhum momento, a aplicação da atividade fugiu do seu controle. Ele soube gerenciar bem o desenvolvimento dela em sala de aula, não deixando que os alunos se dispersassem com outras coisas, porque não conseguiam encontrar uma solução para à questão proposta.

Esse gerenciamento pode ser visto também nos momentos da atividade que apareceram nitidamente na aula. O primeiro momento foi aquele no qual o professor

\footnotetext{
${ }^{50}$ Esse aspecto foi nitidamente mostrado nas respostas do questionário. Iremos aprofundar essa discussão na página 146, deste capítulo.
} 
expôs o problema (atribuir valores para carga e o spin das figuras de maneira a formar um próton e um nêutron, com a mesma lei de formação); o segundo momento, foi o da manipulação das formas e dos números pelos alunos, procurando encontrar uma solução para a questão; o terceiro momento, o do fechamento através das conclusões da atividade, com a formalização dos conceitos ligados a ela.

O tempo de execução também ficou dentro do programado. Tínhamos planejado gastar em torno de 50 minutos (aproximadamente uma aula) e o tempo gasto foi pouco mais do que isso, ficando próximo dos 60 minutos.

Esses são aspectos que acreditamos serem manifestações da terapêutica, mostrando o relativo sucesso do professor ao aplicar a atividade em sala de aula.

Entre os alunos, a terapêutica também se manifestou em um episódio que nos chamou a atenção. O envolvimento e a motivação de um determinado grupo de alunos foi tão grande que eles passaram o final de semana discutindo a solução, procurando o professor na segunda-feira para apresentar uma possível solução para o problema proposto (a atividade foi desenvolvida na sexta-feira). Mostrando assim o sucesso que a atividade obteve entre os jovens alunos.

Desta forma, a terapêutica se manifestou na adaptação do conteúdo à sala de aula, levando a um interesse dos alunos em executar a atividade, conseqüentemente, gerando uma motivação em encontrar uma resposta por eles. Essa característica se manifestou também na aceitação e no gerenciamento da atividade pelo professor.

$\mathrm{O}$ aspecto da atualização também esteve presente na atividade. Ele teve como um dos seus objetivos mostrar que os constituintes do núcleo não eram partículas elementares e sim, constituídos por outras partículas ainda menores, denominadas quarks. Discutir a necessidade de um novo número quântico para que os quarks, no estado ligado, não violassem o princípio da exclusão de Pauli. A descrição da matéria estava, dessa forma, mais próxima daquela aceita e trabalhada pela comunidade científica, justificando assim a atualização biológica desse saber, uma vez que prevê que o saber deva estar próximo daquele vigente na comunidade científica para ser reconhecida sua atualização biológica. Assim, essa atividade contribuiu para uma 
atualização do saber escolar (Regra II), por mostrar uma descrição mais atual da estrutura do núcleo atômico, um novo tipo de carga e uma nova interação da natureza.

Como metáfora, a atividade apresentou uma criatividade didática, mostrando ser um objeto presente somente na sala de aula, estando distante do que é realmente feito nos grandes laboratórios, pois os cientistas não atribuem valores para as propriedades das partículas, eles determinam através de dados experimentais. Aqui, porém, esse artifício foi utilizado como recurso didático para levar a compreensão melhor da estrutura das partículas e da carga cor. Tornou, o conceito mais compreensível (Regra V) para os alunos.

A metáfora ainda serviu para transformar o conceito em exercícios (Regra IV), através das questões trazidas no roteiro da atividade (Enuncie sua regra de formação das partículas. Com essa regra, qual o número máximo de partículas distintas que você consegue "construir" com duas figuras? Dê as características (carga e spin) de cada uma. Os constituintes (as duas figuras) obedecem ao princípio da exclusão de Pauli?). Esse conteúdo gerou exercícios, questões e problemas, podendo, desta forma, ser avaliado pelo professor. A discussão gerada com o desenvolvimento da atividade fez a conexão com um texto sobre o assunto (O modelo dos quarks ${ }^{51}$ ), no qual há questões referentes ao conceito discutido, reforçando o potencial deste saber em gerar exercícios ou questões.

Acreditamos também que o desenvolvimento da atividade corroborou para a classificação dessa atividade como um marcador-estruturante do curso, fazendo ligação entre conceitos estudados anteriormente, como força forte, méson pi e estabilidade do núcleo, com conceitos que foram discutidos posteriormente, como os quarks, glúons e a carga cor. Conceitos que consideramos essenciais no nosso curso de Partículas Elementares.

No entanto, apesar dos alunos terem conseguido desenvolver toda a atividade, parece que eles não haviam compreendido muito bem qual era o objetivo da atividade. Mesmo interessados e motivados em encontrar uma possível resposta para a questão

${ }^{51}$ Anexo I, página 27. 
proposta, essa nova observação pode ser constatada quando aplicamos o questionário com os alunos.

Na questão que pedia para eles assinalarem qual teria sido a atividade que menos haviam gostado, a maioria indicou os constituintes das partículas, explicando (argumentando) que isso se deu devido a pouca compreensão do objetivo da atividade, ou até mesmo por não ter entendido a própria atividade, apesar de todos terem participado ativamente.

$\mathbf{Q}\left(\mathbf{A}_{\mathbf{B}}\right)$ "porque foi algo um pouco complicado"

$\mathbf{Q}\left(\mathbf{A}_{\mathbf{J}}\right)$ : “não entendi muito"

$\mathbf{Q}\left(\mathbf{A}_{\mathbf{M}}\right)$ : “creio que tinha sido um dos exercícios mais complicado"

$\mathbf{Q}\left(\mathbf{A}_{\mathbf{N}}\right)$ : “muito complicado"

$\mathbf{Q}\left(\mathbf{A}_{\mathbf{P}}\right)$ : "porque achei a mais difícil"

$\mathbf{Q}\left(\mathbf{A}_{\mathbf{Q}}\right)$ : "pois achei cansativa, pela sua apresentação"

Essas respostas nos forneceram indícios que talvez o problema com a atividade esteja ligado a sua complexidade e/ou à maneira não muito clara que foi exposta, através do roteiro e da explicação do professor. Contudo, só poderemos ter dados mais conclusivos quando analisarmos futuras aplicações dessa atividade.

Isso pode justificar o tempo maior na execução da atividade pelos alunos, pois foi necessário que o professor fizesse intervenções nos grupos, procurando esclarecer melhor a atividade para os alunos encontrarem alguma resposta coerente à questão proposta.

Desta forma, essa é uma atividade que acreditamos ser necessário fazer uma reformulação para que possa ter seu objetivo mais explícito e assim contribuir ainda mais para a compreensão dos conceitos ligados a ela, como a carga cor e os quarks. 


\section{3 - A análise da estrutura do curso: o questionário}

Para analisar o conteúdo do curso utilizamos um questionário (em anexo) com perguntas objetivas. Desta forma, procuramos colocar questões objetivas sobre a sequiência, as atividades, as questões e outros elementos que acreditamos serem pertinentes para poder fazer uma avaliação geral da estrutura do curso, ou seja, procuramos obter uma visão panorâmica do mesmo, segunda a visão dos alunos.

Apesar de nosso espaço amostral ser pequeno (apenas 16 alunos responderam ao questionário), pois já era período de recuperação na escola, e a grande maioria já não freqüentá-la mais, conseguimos tecer algumas considerações que poderemos, em um trabalho futuro, explorar mais.

Na primeira parte do questionário, procuramos avaliar se a linguagem utilizada nos textos estava acessível, bem como as questões e exercícios propostos. Quanto à compreensão, a maioria (10 alunos) disse que foram fáceis de compreender. Essa porcentagem aumentou quando procuramos avaliar a utilidade dos textos para a compreensão da matéria (12 alunos). E segundo os alunos, esses textos ajudaram a responder as questões e os exercícios propostos (9 alunos).

Isso nos fornece indícios da regra $\mathrm{V}$, mostrando que foi possível tornar os conceitos mais compreensíveis, através de uma linguagem mais acessível, de forma que o aluno pudesse compreender o novo saber. Acreditamos que essa melhor compreensão também esteja ligada às atividades elaboradas em algumas aulas, uma vez que os alunos foram capazes de executá-las e de responder às questões propostas nos roteiros.

Quanto aos exercícios e às questões, onze alunos responderam que foram fáceis de ser entendidos e compreendidos. Porém, nove alunos disseram que foram difíceis de serem respondidos. Esse fato, de certa forma, já era esperado, uma vez que as questões elaboradas não estavam nos padrões tradicionais encontrados nos livros de Física de Ensino Médio. No entanto, as discussões em sala de aula ajudaram muito a responder essas questões e exercícios (dez alunos). Quanto a quantidade de exercícios e questões, eles disseram que foram suficientes (dez alunos). 
Essa análise fornece indicativos que obtivemos êxito na regra IV, indicando que conseguimos transformar o saber em exercícios, problemas e questões. Mesmo que essas questões não estejam nos moldes das questões comumente trabalhadas por eles nas aulas de Física, eles conseguiram respondê-las satisfatoriamente, entendendo que um novo contrato didático estava sendo proposto.

Buscamos também fazer um levantamento sobre a estrutura do curso na visão dos alunos, para tentar perceber se eles haviam notado que os assuntos discutidos nas aulas estavam ligados entre si, formando um todo coerente. Assim, nove alunos responderam que as aulas e o conteúdo estavam ligadas umas às outras e seis disseram que estavam muito ligadas. Isso mostrou que a estrutura do curso foi percebida pelos alunos, como mostra a resposta de um deles:

$\mathbf{Q}\left(\mathbf{A}_{\mathbf{M}}\right):$ "Acompanhando as aulas era possível ter uma compreensão fácil da matéria. Porém é algo que, se perdendo uma aula, pode-se ficar um pouco perdido."(sic)

Um outro aspecto marcante nas respostas dos alunos sobre os exercícios e questões, foi a diferença existente entre esse curso e os outros que tiveram nos anos anteriores.

\section{$\mathbf{Q}\left(\mathbf{A}_{\mathbf{D}}\right)$ : "Muito raciocínio sem cálculos"}

$\mathbf{Q}\left(\mathbf{A}_{\mathbf{G}}\right)$ : "Nos anos anteriores só tinha conta."

$\mathbf{Q}\left(\mathbf{A}_{\mathbf{H}}\right):$ "Teve uma "prática" nas aulas, coisa que não acontecia em anos anteriores."

\section{$\mathbf{Q}\left(\mathbf{A}_{\mathbf{P}}\right):$ "Este curso teve mais conteúdo."}

No questionário conseguimos ainda, levantar algumas impressões que os alunos tiveram sobre a estrutura da matéria e o mundo ao seu redor, mostrando que o curso buscou modernizar (Regra I) e atualizar o saber escolar (Regra II), levando uma visão mais atual do átomo e da própria estrutura da matéria. Essas impressões foram 
levantadas quando perguntamos se houve alguma mudança na maneira deles olharem o mundo ao seu redor após o curso. Obtivemos as seguintes respostas:

$\mathbf{Q}\left(\mathbf{A}_{\mathbf{C}}\right):$ "Para nós que somos leigos mudou totalmente a noção daquilo que se chama átomo."

$\mathbf{Q}\left(\mathbf{A}_{\mathbf{E}}\right):$ "O mundo não é só o que vejo mais é muito mais além de nossa visão."

$\mathbf{Q}\left(\mathbf{A}_{\mathbf{G}}\right):$ "Soube de coisas que nem imaginava."

$\mathbf{Q}\left(\mathbf{A}_{\mathbf{N}}\right):$ "Não sabia quantas coisas menores existiam."

$\mathbf{Q}\left(\mathbf{A}_{\mathbf{0}}\right)$ : "Na verdade o mundo é uma caixinha de surpresas."

$\mathbf{Q}\left(\mathbf{A}_{\mathbf{P}}\right):$ "Eu achava que só existiam elétrons e prótons dentro do núcleo."

O questionário buscou levantar também as concepções que os alunos possuíam sobre o ensino de Física e um pouco da própria Física. Para isso questionamos os alunos sobre o que eles pensavam que era a Física. A maioria apresentou uma resposta baseada em uma disciplina com muitos cálculos, algo parecido com a matemática, uma matéria a mais no currículo da escola, que não despertava interesse algum por ela, devido a grande quantidade de contas utilizadas. Esses aspectos apontados pelos alunos, nos levam a concluir que o ensino de Física que eles receberam em anos anteriores era um ensino muito tradicional, baseado em muitas contas e nenhuma atividade.

Isso se revelou também em alguns questionários quando deixamos uma pergunta em aberto para eles fazerem os comentários que achassem necessários. Surgiram respostas como: "nos anos anteriores só tinha conta.", “ as aulas foram não convencionais", "teve prática nas aulas, coisa que não acontecia nos anos anteriores".

Contudo, o curso levou-os a perceber uma outra forma de ensinar Física, mostrando que a Física pode ser mais atrativa e interessante para os alunos do Ensino Médio. Em uma questão procuramos levantar essa mudança ocorrida com eles, sobre o diferencial do curso em relação aos anos anteriores, obtendo as seguintes respostas: 
$\mathbf{Q}\left(\mathbf{A}_{\mathbf{B}}\right)$ : “As aulas foram muito mais interessantes do que eram nos anos anteriores."

$\mathbf{Q}\left(\mathbf{A}_{\mathbf{C}}\right)$ : “A forma como foi apresentado, detalhes que antes não eram cotados."

$\mathbf{Q}\left(\mathbf{A}_{\mathbf{M}}\right)$ : "Um curso interessante que não subestimou a inteligência e a capacidade dos alunos."

$\mathbf{Q}\left(\mathbf{A}_{\mathbf{N}}\right)$ : “Antes aprendi, distância, velocidade, etc. Já esse ano aprendi coisas interessantes sobre o átomo."

$\mathbf{Q}\left(\mathbf{A}_{\mathbf{0}}\right):$ "O curso mostrou que existem coisas que estão fora da nossa imaginação."

Podemos constatar que houve uma mudança na maneira deles olharem o trabalho científico e a própria ciência, mostrando que começaram a compreender que a ciência é um empreendimento humano e muito dinâmico. Para isso, procuramos mostrar, no curso, a evolução ocorrida no conceito de átomo e perguntamos se eles haviam notado e se achavam que essas mudanças iriam parar. As respostas de todos os alunos foram idênticas, todos acreditavam que não. Contudo, os argumentos para isso não foram os mais diversos, como algumas das respostas a seguir:

$\mathbf{Q}\left(\mathbf{A}_{\mathbf{D}}\right):$ "Não, o que não existe, não existe; porém o que não se descobriu não significa que não pode ser descoberto."

$\mathbf{Q}\left(\mathbf{A}_{\mathbf{H}}\right):$ "Não, pois o ser humano está sempre procurando evoluir cada vez mais."

$\mathbf{Q}\left(\mathbf{A}_{\mathbf{L}}\right):$ "Não, pois a ciência começou agora e ninguém mais vai poder parar o seu avanço.”

$\mathbf{Q}\left(\mathbf{A}_{\mathbf{M}}\right):$ "Não, pois com o passar o tempo, as idéias vão mudando, conhecimento são adquiridos. $O$ que um descobre é passado para frente, proporcionando uma evolução natural." 
Um outro aspecto que ficou nítido no fechamento do curso, foi a mudança no interesse, no comportamento e na presença dos alunos nas aulas de Física (lembrando que as aulas ocorriam nos dois últimos horários de sexta-feira, no noturno). Quando iniciamos o curso, haviam 31 alunos na primeira aula (atividade dos raios X) e alguns, apesar de estarem estranhando um pouco a presença da câmera, tiveram um comportamento ruim no final da aula.

Contudo, na última aula, ainda contávamos com a presença de 35 alunos, quando foi feito o fechamento do curso com a discussão da carga cor, quarks e glúons, Essa aula foi totalmente expositiva, porém gerou discussões entre os alunos e o professor, o que contribuiu para o bom aproveitamento e interesse por ela.

Todas essas respostas e observações apresentadas reforçam ainda mais a operacionalidade do curso e a terapêutica, indicando que ele obteve um relativo sucesso entre os alunos e que as atividades foram possíveis de serem executadas, não sendo apresentado pelos alunos nenhum obstáculo para sua aplicação. Muito pelo contrário, houve grande motivação entre eles em discutir e desenvolver assuntos novos sobre a Ciência.

Assim, o curso atingiu em partes seu objetivo, que foi também o de levar para os jovens alunos do Ensino Médio uma visão da Ciência Moderna, contrastando com uma que, em alguns casos, é distorcida totalmente estática feitos por gênios vindos de outros planetas. 


\section{CONSIDERAÇÕES FINAIS}

A elaboração, aplicação e análise da seqüência didática, revelou resultados positivos e o sucesso da proposta do curso, foi tanto do ponto de vista dos alunos, quanto do ponto de vista do professor que o ministrou. Os resultados obtidos são promissores, pois forneceram um panorama das dificuldades, dos obstáculos, das contribuições metodológicas e legitimou o instrumento de análise - a Transposição Didática.

A maior dificuldade que tivemos em aplicar o curso foi referente à carga horária. Percebemos que não é fácil levar uma proposta de atualização curricular para as escolas públicas (estaduais) se a carga horária ultrapassar 40 aulas. Isso porque muitas das 80 aulas que deveriam ocorrer durante o ano letivo são ocupadas com comemorações, festividades, passeios, conselhos de classe, reuniões com pais, entre outras coisas que conseguimos constatar durante a aplicação.

Contudo, não tivemos dificuldades em motivar os alunos a estudar e a discutir a Física de Partículas Elementares, acreditando que isso só foi possível devido à elaboração de atividades que auxiliaram a aprendizagem de determinados conceitos, tornando-os mais significativos para os alunos, apesar de sua complexidade.

Apesar de a aprendizagem não ter sido o foco desta pesquisa podemos inferir que não houve grandes dificuldades que pudessem impedir o acompanhamento e o desenvolvimento das aulas. As dificuldades não foram muito diferente daquelas dificuldades presentes no aprendizado da Física Clássica. Contudo, acreditamos que não tenha se manifestado tanto, devido à grande motivação que tiveram para estudar os conceitos.

Porém, esperamos ter resultados que nos levem à conclusões mais fiéis, quando novas aplicações ocorrerem e que esse aspecto seja investigado com mais profundidade e com mais riqueza. 
Com a análise feita, chegamos à conclusão que foi possível levar a proposta do curso sobre a Física de Partículas Elementares para jovens do Ensino Médio. Apesar de ser um assunto complexo, conseguimos fazer uma adaptação desse conhecimento para que fosse alcançado pelos alunos.

Embora, não tenhamos conseguido aplicar todo o curso, cremos que toda a sequiência ficou estruturada, permitindo futuras aplicações para que possa vir a confirmar a nossa hipótese. Isso já está sendo feito. Temos atualmente, quatro professores de escolas públicas estaduais, na cidade de São Paulo, aplicando toda a sequiência didática, indicando que as atividades elaboradas, os textos adaptados e as discussões são possíveis de serem aplicadas em sala de aula.

Um outro aspecto que também conseguimos obter sucesso, foi com a abordagem. Como foi visto no capítulo 3, não há um consenso da comunidade de ensino de Física sobre qual seria a melhor abordagem a ser utilizada na inserção da Física Moderna e Contemporânea na sala de aula. Contudo, ao utilizar a abordagem fenomenológicaconceitual, obtivemos sucesso com o conteúdo da Física de Partículas Elementares. Quando um fenômeno é trazido para discussão em sala de aula, através de uma atividade, o conceito que se quer ensinar, torna-se mais significativo para os alunos.

Segundo Arons (1990), alguns conceitos de FMC devem ser ensinados no E.M., tendo como objetivo levar alguma percepção aos alunos sobre conceitos Modernos e Contemporâneos. A Física Clássica seria inserida na perspectiva de suporte para os conceitos da FMC, ou seja, a Física Clássica é usada como sustentação para a abordagem dos tópicos da FMC. Nessa linha, conseguimos elaborar, aplicar e obter sucesso no curso, a partir da introdução de somente alguns conteúdos essenciais da Física Clássica na sequiência de Física de Partículas Elementares.

O trabalho nos mostrou também que é possível transpor os principais obstáculos apontados pela literatura referente à inserção da Física Moderna, que se manifestaram em nossa proposta. O primeiro obstáculo encontrado foi à questão do material didático apropriado para os alunos e para os professores. Foi possível superá-lo com a confecção de material adequado tanto para o aluno quanto para o professor, de tal maneira, que fugisse dos modelos dos livros didáticos tradicionais. A Física de Partículas 
Elementares foi resumida em poucas tabelas, através da descrição do Modelo Padrão, deixando de lado toda riqueza fenomenológica que lhe é peculiar, as motivações das descobertas de novas partículas, o desenvolvimento de novas teorias e novas leis e a geração de novas tecnologias.

O segundo obstáculo foi referente às atividades. Por se tratar de um assunto pouco explorado em sala de aula, poucas são as atividades práticas existentes sobre esse tópico. Como tínhamos a preocupação em estruturar o curso de uma maneira mais dinâmica, com o aluno interagindo, discutindo os conceitos e propondo hipóteses. Assim, as atividades tornaram-se ponto chave do curso, tornando-se alicerces do mesmo. Por isso a grande maioria das atividades se tornou marcadores-estruturantes.

Assim, tentamos fazer com que o aluno discutisse, executasse atividades e não ficasse esperando receber todas as informações do professor passivamente. Tivemos então que buscar atividades práticas que pudessem dar esse caráter dinâmico ao curso. E isso foi, de certa forma, alcançado. Conseguimos elaborar atividades que fizeram os alunos interagirem e discutirem mais sobre os conceitos que seriam tratados, através de questões problematizadoras, obtendo sucesso com as atividades.

As atividades tiveram também uma contribuição relevante na discussão dos conceitos durante as aulas, pois as analogias e as metáforas que foram criadas puderam esclarecer mais os conceitos, auxiliando o aprendizado dos alunos. Essa foi uma indicação de que foi possível gerar uma criatividade didática, no sentido da Transposição Didática. Uma vez que no início, pensávamos que a criatividade didática poderia ser um obstáculo para transpor esse saber e validar o curso.

Outro obstáculo na aplicação da proposta, foi a formação do professor. Esse foi um aspecto marcante na nossa proposta, pois acreditávamos que os professores, por terem tido formação em Universidades públicas de alto nível, reuniriam as condições adequadas para aplicar o curso. Contudo, nenhum deles havia estudado esse assunto na graduação, ou seja, tínhamos professores que nunca haviam trabalhado e nem sequer haviam estudado sobre a maioria dos conceitos tratados na proposta. A forma que encontramos para solucionar esse problema foi capacitá-los ao longo do processo. Isso requereu uma preparação prévia do curso e um acompanhamento durante a aplicação. 
Como a abordagem utilizada estava fora daquela comumente utilizada na maioria das escolas, tivemos também que passar muitas horas discutindo a abordagem que seria utilizada na proposta, visando familiarizá-los com as atividades, objetivos e a dinâmica das aulas.

Assim, obtivemos muito sucesso com essa capacitação dos professores, já que, inicialmente, os novos conceitos foram sendo discutidos e amadurecidos aos pouco paralelamente às inovações metodológicas necessárias.

Por último, esbarramos no obstáculo referente ao formalismo matemático. A Física de Partículas Elementares é uma área da Ciência que utiliza uma linguagem matemática sofisticada para descrever as interações, os estados de energia das partículas e outros conceitos que lhe são peculiares. Ao optar pela abordagem fenomenógicaconceitual, conseguimos adaptar toda essa descrição matemática em conceitos que pudessem ter o rigor bem próxima daqueles utilizados pelas equações. Assim, discutimos vários fenômenos para que os conceitos pudessem ser compreendidos, sem a necessidade da matemática, porque esta é muito avançada para o nível dos alunos do Ensino Médio e, às vezes, até para professores que se formaram há bastante tempo.

Assim, concluímos que sempre existirão obstáculos a serem transpostos na busca por atualizações curriculares. Contudo, são possíveis de serem superados, iniciando com um mapeamento prévio das dificuldades, o trabalho colaborativo com os professores do Ensino Médio e o suporte de um referencial teórico para elaboração e avaliação das atividades.

Em relação aos alunos, a proposta trouxe uma motivação para os jovens estudarem mais a Física, pois perceberam que ela não se resume somente a contas com velocidade, aceleração, bloquinhos, termômetros e etc. Perceberam também que os conceitos, as partículas e as teorias são desenvolvidos e encontrados com a colaboração de diversos cientistas, que trabalham em grupos, contribuindo para uma concepção mais realista da Ciência Contemporânea e do trabalho científico. 
Nesse sentido, foi possível aplicar um pouco sobre a Ciência atual, discutindo aspectos como validação de teorias, o papel dos modelos para a Ciência e buscando alterar um pouco a concepção estereotipada da Ciência.

Foi de extrema importância conseguir transmitir para os alunos que existem outras partículas que vão além dos prótons, elétrons e nêutrons, mostrando toda a evolução da idéia do átomo, desde os gregos até os quarks. Isso permitiu uma atualização na visão de mundo material, segundo a trilha dos constituintes últimos da matéria. Com isso, percebemos que a maioria dos alunos assimilou a idéia de que não existem verdades absolutas na Ciência e nem modelos perfeitos e definitivos na representação da natureza.

A proposta contribuiu para a formação de um aluno mais crítico, mais participativo e mais consciente das discussões acerca da Ciência Contemporânea, aproximando-se dessa área de conhecimento.

Outro aspecto importante da pesquisa foi o uso da Transposição Didática. Acreditamos que através dela foi possível realçar as nuances da proposta, analisando toda a adaptação feita durante a elaboração e aplicação do curso. Essa teoria pode-se tornar um referencial pedagógico para análise de novas propostas de ensino. Isso porque esse instrumento conseguiu apontar que as transformações ocorridas no saber são possíveis ou não de serem realizadas para que, de fato, se torne um "saber de sala de aula". Com isso, a Transposição Didática foi capaz de mostrar que, para o nosso caso, a Física de Partículas Elementares pode se tornar um saber de sala de aula, validando a nossa seqüência didática.

A partir de tudo que foi exposto acima, podemos afirmar que foi possível elaborar uma proposta de ensino sobre as partículas elementares, aplicá-la em sala de aula para que fosse validada com mais segurança. Isso nos deixou, com certeza, muito satisfeitos.

Eu me senti gratificado por ver que um sonho, elaborado por mais de dez anos, foi realizado. Estudar e compreender um pouco mais sobre a Física de Partículas foi de suma importância para que a elaboração dessa proposta (que era a de levar uma Física mais atraente para os jovens que cursam o Ensino Médio) fosse possível. 


\section{REFERÊNCIAS BIBLIOGRÁFICAS}

ABDALLA, Maria Cristina. O discreto charme das partículas elementares. São Paulo: Unesp, 2006.

ALLDAY, J. The Nature of Force in Particle Physics. Physics Education, Bristol, v.32, n.5, p.327-332, sept. 1997.

ALVARENGA, Beatriz in: CARUSO, Francisco; SANTORO, Antonio. Do átomo grego à Física das interações fundamentais. Rio de Janeiro. AIAFEX, p.179-196, $2^{\mathrm{a}}$ edição, 2000.

ALVARENGA, Beatriz; MÁXIMO, Antônio . Curso de Física. $5^{\mathrm{a}}$ ed., V.3. São Paulo: Scipione, 2000.

Curso de Física. 5a ed., V.2. São Paulo: Scipione, 2000.

ALVES, Gilson; CARUSO, Francisco; FILHO, Hélio da Motta; SANTORO, Alberto. O mundo das partículas de hoje e de ontem. Rio de Janeiro: CBPF, 2000.

AMALDI, Ugo. Imagens da Física - As ideais e as experiências do pêndulo aos quarks. São Paulo: Scipione, 1995.

ASTOLFI, Jean Pierre e DEVELAY, Michel. A Didática das Ciências. $10^{\mathrm{a}}$ ed. Campinas: Papirus, 2006.

ASTOLFI, Jean Pierre et al. Mots-clés de la didactique des sciences. Pratiques Pèdagogies, De Boeeck \& Larcier S. A. Bruxelas, 1997.

AUBRECHT, C. J. Redesignig courses and texbooks for the twenty-first century. American Journal of Physics, V.57, n.4, p.352-359, 1989.

BARLOW, R. Particle Physics: from school to University. Physics Education, Bristol, v.27, n.2, p.92-95, mar. 1992. 
BARRETO, Jorge L. V. A descoberta do nêutron. p 151-160. In: Partículas elementares: 100 anos de descobertas. CARUSO, F.; OGURI, V.; SANTORO, A. (org.) Editora da Universidade Federal do Amazonas, Manaus: 2005.

BORGES, Oto N., et al. Reformulação do currículo de Física do Ensino Médio em Minas Gerais: versão preliminar do currículo proposto. Atas: XII Simpósio Nacional de Ensino de Física, Belo Horizonte, p.213-223, jan. 1997.

BRASIL. Parâmetros Curriculares Nacionais para o Ensino Médio. Ministério da educação. Secretária da Educação Média e Tecnológica. Brasília, 1999.

BROCKINGTON, Guilherme. A Realidade escondida: a dualidade onda-partícula para alunos do Ensino Médio. São Paulo, curso de pós-graduação em ensino de Ciências - USP, 2005. Dissertação de mestrado.

CAMARGO, A. J. A introdução da física moderna no $\mathbf{2}^{\circ}$ grau: Obstáculos e possibilidades. Florianópolis, curso de pós-graduação em educação - UFSC, 1996, Dissertação de Mestrado.

CARUSO, Francisco; OGURI, Victor. A eterna busca do indivisível: do átomo filosófico aos quarks e léptons. Química Nova, n.3, v.20, p324-334, maio/jun.1997.

CARUSO, Francisco; OGURI, Vitor; SANTORO, Alberto. Partículas elementares: 100 anos de descoberta. Manaus: Editora da Universidade Federal de Manaus, 2005 .

CARUSO, Francisco; SANTORO, Alberto. Do átomo Grego à Física das interações fundamentais. $2^{\mathrm{a}}$ ed. Rio de Janeiro: AIAFEX, 2000.

CARVALHO, A. M. P, GIL-PEREZ, D. Formação de professores de ciências. São Paulo: $6^{\mathrm{a}}$ ed. Cortez, 2001.

CARVAlHO, A. M. P. Critérios Estruturantes para o Ensino das Ciências. Ensino de Ciências: unindo a pesquisa e a prática. Pioneira Thomsom Larning, São Paulo, 2004. 
CARVALHO, A. M. P.; VANNUCHI, Andéa. O currículo de Física: inovações e tendências nos anos noventa. Investigações em Ensino de Ciências. Porto Alegre, V.1, n.1, p.3-19, abr.1996.

CAVAlCANTE, Marisa A. O ensino de uma NOVA FÍSICA e o exercício da cidadania. Revista Brasileira de Ensino de Física, V.21. n.4, p.550-551, dez.1999.

CAVAlCANTE, Marisa A.; TAVOLARO, Cristiane R. C. Uma oficina de Física Moderna que vise a sua inserção no Ensino Médio. Caderno Catarinense de Ensino de Física. Florianópolis, V.18, n.3, p.298-316, dez.2001.

CHEVAlLARD, Yves. La Transposicion Didactica: Del saber sabio al saber enseñado. $1^{\text {a }}$ ed. Argentina: La Pensée Sauvage,1991.

COELHO, Hélio T., ROBILOTTA, Manoel R. Forças Nucleares. Ciência Hoje, v.11, n.63, p.23, 1990.

CRUZ, F. F. de S. Radioatividade e o acidente de Goiânia. Caderno Catarinense de Ensino de Física, Florianópolis, v.4, n.3, p. 164-169, dez. 1987.

DE POSADA APARICIO, J. M. Concepciones de los Alumnos de 15-18 años sobre la Estructura Interna de la Materia en el Estado Sólido. Enseñanza de las Ciencias, Barcelona, v.11, n. 1, p. 12-19, 1993.

DELIZOICOV, D.; ANGOTTI, J. A. Metodologia do ensino de ciências. Editora Cortez.

FAGUNDES, M. Beatriz. Ensinando a dualidade onda-partícula sob uma nova óptica. São Paulo, curso de pós-graduação em ensino de Ciências - USP, 1997. Dissertação de Mestrado.

FARMELO, G. Teaching Particle Physics in the Open University's Science Foundation Course. Physics Education, Bristol, v.27, n.2. p. 96-101, mar. 1992.

FELTRE, Ricardo. Química. 5a ed., V.1. São Paulo, Moderna, 2000. 
Química. 5a ed., V.3. São Paulo, Moderna, 2000.

FERRARO, Nicolau Gilberto; SOARES, Paulo Antônio de Toledo. Física básica. $2^{\mathrm{a}}$ ed. São Paulo: Atual, 2004

FEYNMAN, Richard P. QED: A estranha teoria da luz e da matéria. $1^{\text {a }}$ ed. Lisboa: Gradiva, 1988.

FREIRE JR, Olival; CARVALHO NETO, Rodolfo Alves. O universo dos quantas: uma breve história da física moderna. São Paulo: FTD, 1997.

Fundamental Particle and Interactions Chart Committee. Fundamental Particles and Interactions: a wall chart of moderm physics. The Physics Teacher, Story Brook, v. 26, n. 9, p. 556-565, dec. 1998.

GASPAR. Alberto. Física - Eletromagnetismo e Física Moderna. $1^{\mathrm{a}}$ ed, V.3. São Paulo: Ática, 2001

GIL. D. P., SENENT, F., SOLBES, J. La introducción a la Física Moderna: um ejemplo paradigmatico de cambio conceptual. Enseñanza de las ciências. Barcelona: p.209210, n. Extra, set. 1987.

GILMORE, Robert. Alice no país do Quantum: a Física Quântica ao alcance de todos. Rio de Janeiro: Jorge Zahar ed, 1998.

O mágico dos Quarks: a física de partículas ao alcance de todos. Rio de Janeiro: Jorge Zahar, 2002.

GRECA, Ileana Maria; MOREIRA, Marco Antônio. Uma revisão da literatura sobre estudos relativos ao ensino da mecânica quântica introdutória. Investigação em ensino de ciência. Porto Alegre: V.6, N.1, março de 2002.

GUALTER, José Biscuola et alli. Tópicos de Física 3. 15ª ed. São Paulo: Saraiva, 2001. 
GUTIÉRREZ, Elena Ester, et al. Qué Piensan los Jóvenes sobre Radiactividade, Estructura Atómica y Energía Nuclear? Enseñanza de las Ciencias, Barcelona, v.18, n. 2, p. 247-254, 2000.

GUZZO, Marcelo; NATALE, Adriano. Introduzindo os neutrinos. p.193-208. In: Partículas elementares: 100 anos de descobertas. CARUSO, F.; OGURI, V.; SANTORO, A. (org.) Editora da Universidade Federal do Amazonas, Manaus: 2005.

HALLIDAY, David e RESNICK, Robert. Fundamentos de física. 3. ed. Rio de Janeiro: Livros Técnicos e Científicos, 1994. 4 v.

HANLEY, Phil. Teaching Particle Physics. Physics Education, v.35, n. 5, sept. 2000.

HARVARD PROJECT PHYSIC. Unidade Suplementar A. Partículas elementares. Lisboa: Fundação Calouste Gulbenkian, 1987.

HEWITT, Paul. Física Conceitual. 9ª ed. Porto Alegre: Bookman, 2002.

JONES, D. G. C. Cosmology and Particle Physics. Physics Education, Bristol, v. 27, n. 2, p. 76-80, mar. 1992.

KALMUS, P. I. Particle physics at A-level-the universities viewpoint. Physics Educations. Bristol: V.27, n.2, p.62-64, mar. 1992.

KUHN, T. A estrutura das revoluções científicas. Perspectiva, $8^{a}$ ed. São Paulo: 2003.

LÜDKE, Menga; ANDRÉ, Marli E. D. A. Pesquisa em educação: abordagem qualitativa. São Paulo: EPU, 1986.

MARINELli, J. R. Enxergando o Núcleo atômico. Caderno Catarinense de Ensino de Física, Florianópolis, v.6, n. 3, p. 234-240, dez. 1989.

MARTNAND, J. L. Connaître et Transformer la Matière. Peter Lang, Berna, 1986. 
MATTHEUS, M.R. Vino viejo en botellas nuevas: un problema con la epistemología constructivista. Tradução para o espanhol: Óscar Barberá \& Luís Puig. Enseñanza de las ciencias, Barcelona: v.12, n.1, p.79-88, 1994.

MAYRING, Philipp. Introdução à pesquisa social qualitativa - Uma introdução para pensar qualitativamente. $5^{\mathrm{a}}$ ed. 2002.

MENDELEYEV, D. The principles of chemistry, 3 rd, English ed. Longmans, Green \& Co., New York, 1905

MENEZES, Luis Carlos de. A matéria uma aventura do espírito: fundamentos e fronteiras do conhecimento físico. São Paulo: Livraria da Física, 2005.

MENEZES. Luís Carlos; HOSOUME, Yassuko. Para lidar com o mundo real, a Física escolar também precisa ser quântica. Atas: XII Simpósio Nacional de Ensino de Física, Belo Horizonte, p.282-230, jan. 1997.

MIGNACO, Juan Alberto; SHELLARD, Ronald Cintra. A matéria indivisível. Ciência Hoje. V.3, n.14, p.41-49, set/out.84

MOREIRA, Alysson Magalhães e VALADARES, Eduardo de Campos. Ensinando física moderna no segundo grau: efeito fotoelétrico, laser e emissão de corpo negro. Caderno Catarinense de Ensino de Física. Florianópolis: V.15, n. 2: p. 121-135, ago. 1998.

MOREIRA, Marco Antônio. Um mapa conceitual sobre partículas elementares. Revista Brasileira de Física. V.11, p.114-129, dez 89.

Partículas e interações. Revista A Física na escola, V.5, n.2, p.10-14, out 2004.

MOTTA, Hélio da. O próton. p.123-131. In: Partículas elementares: 100 anos de descobertas. CARUSO, F.; OGURI, V.; SANTORO, A. (org.) Editora da Universidade Federal do Amazonas, Manaus: 2005. 
MOZAS, T., RUIZ, G. Introducción al Modelo de Partículas. Enseñanza de las Ciencias, Barcelona, n. Extra, p.281-283, 1989.

NATALE, Adriano A.; GUZZO, Marcelo M. Neutrino: partículas onipresentes e misteriosas. Ciência Hoje. V.25, n.147, p.34, mar.99

NOVELLO, Mário. Os sonhos atribulados de Maria Luíza: uma alegoria da cosmologia e da física. Rio de Janeiro: Jorge Zahar ed., 2000

OSTERMANN, F. Um texto para professores do ensino médio sobre partículas elementares. Revista Brasileira de Ensino de Física. V.21, n.3, p.415-436, set 99. Partículas elementares e interações fundamentais. Instituto de Física - UFRGS. Porto Alegre, 2001 (Texto de apoio ao professor de Física, V.12).

OSTERMANN, Fernanda; CAVALCANTI, Cláudio. Física Moderna e Contemporânea no ensino médio: elaboração de material didático, em forma de pôster, sobre partículas elementares e interações fundamentais. Caderno Catarinense de Ensino de Física. Florianópolis, V.16, n.3, p.267-286, dez.99.

OSTERMANN, F; MOREIRA, M A. Atualização do currículo de Física na escola de nível médio: um estudo desta problemática na perspectiva de uma experiência em sala de aula e da formação inicial de professores. Caderno Catarinense de Ensino de Física, Florianópolis, V.18, n.2, p.135-151, ago 2001.

. Física contemporánea em la escuela secundaria: uma experiencia en el aula involucrando formación de profesores. Enseñanza de las ciencias, Barcelona: v.18, n.3, p.391-404, 2000.

Tópicos de Física Contemporânea na escola média brasileira: um estudo com a técnica Delphi. In: Encontro de Pesquisa em Ensino de Física, 6., 1998. Atas. Florianópolis: Imprensa UFSC, 19p.[Seção de comunicação Orais] 1 CD-Rom. 
. Uma revisão bibliográfica sobre a área de pesquisa

"física moderna e contemporânea no ensino médio". Investigação em ensino de ciência. Porto Alegre: V.5, N.1, março 2000.

PAULA, Leandro de; GANDELMAN, Mirian. A assimetria do Universo: Porque existe mais matéria do que antimatéria? Ciência Hoje. V.25, n.148, p.30-37, abr.99

PEREIRA, O. da S. Raios Cósmicos: introduzindo física moderna no $2^{\circ}$ grau. São Paulo: Instituto de Física e Faculdade de Educação - USP, 1997, Dissertação de Mestrado em Ensino de Ciências.

PEREIRA, O. S. Visão de estudantes sobre a inserção de Física Moderna e Contemporânea no $2^{\circ}$ grau. Atas: XII Simpósio Nacional de Ensino de Física, Belo Horizonte, p.551-558, jan. 1997.

PIETROCOLA, Maurício et al. A perturbação do contrato didático e o gerenciamento dos paradoxos. Investigações em Ensino de Ciências. Porto Alegre, V.8, n.3, ago/2002.

PINHEIRO, T. F.; PIETROCOLA, M.; ALVES FILHO, J. F ${ }^{o}$. Modelização de variáveis: uma maneira de caracterizar o papel estruturante da matemática no conhecimento científico. Ensino de Física: conteúdo, metodologia e epistemologia numa concepção integradora. Pietrocola, M. (org.). Editora UFSC/INEP, Florianópolis, 2001.

PINHO ALVES, José $\mathrm{F}^{\mathrm{o}}$. Atividades Experimentais: Do método à Prática Construtivista. Tese de Doutorado, UFSC, Florianópolis, 2000.

. Regras da Transposição Didática Aplicada ao Laboratório

Didático. Caderno Catarinense de Ensino de Física, Florianópolis, V.17, n.2, p.174-188, ago.2000.

PINTO, A.C., ZANETIC, J. É possível levar a física quântica para o ensino médio? Caderno Catarinense de Ensino de Física, Florianópolis, V.16, n.1, p.7-34, abril 99. 
PIRES, Antônio Sérgio Teixeira. Solução para o desconcertante. Ciência Hoje. V.33, n.193, p.76-79, maio 2003.

ROBIlOTTA, M. R. Construção e Realidade no ensino de Física. São Paulo: monografia, IFUSP, 1985.

. O Cinza, o Branco e o Preto: da relevância da História da Ciência no Ensino de Física. Caderno Catarinense de Ensino de Física. V.5, n. especial, p.7-22, 1987.

ROBILOTTA, M. R.; BABICHAK, C. C. Definições e conceitos em Física. Cadernos Cedes. Ano XVIII, p.35-61, n.41, jul 1997.

RODRIGUES, Carlos Daniel Ofugi. Inserção da Teoria da relatividade no ensino médio: Uma nova proposta. Florianópolis, curso de pós-graduação em educação UFSC, 2001 Dissertação de Mestrado.

RYDER, L. The new Elementary Particles and Charm. Physics Education, Bristol, v. 21, n. 1, p. 28-32, jan. 1976.

RYDER, L. The Standard Model. Physics Education, Bristol, v. 27, n. 2, p. 66-70, mar.1992.

SALMERON, Roberto A. Física Nuclear, raios cósmicos e as origens da Física de Partículas. In: Partículas elementares: 100 anos de descobertas. CARUSO, F.; OGURI, V.; SANTORO, A. (org.) Editora da Universidade Federal do Amazonas, Manaus: 2005.

SAMPAIO, José Luiz; CALÇADA, Caio Sérgio. Física. V. único. São Paulo: Atual, 2003.

SCHWARZ, Cindy. A tour of the subatomic zôo: A guide to particle physics. $1^{\text {a }}$ ed. New York. Americam Institute of Physics.1992. 
SCOCCOLA, Norberto. Pentaquark: nova partícula subatômica? Ciência Hoje. V.35, n.210, p.36-40, nov.2004.

SEGRÉ, E. Dos raios $\mathrm{X}$ aos Quarks. Físicos Modernos e suas Descobertas. Universidade de Brasília, Brasília, 1982.

SILVA, Walkiria Reche da. Inserção de tópicos da nova física da estrutura da matéria no ensino médio: uma proposta. São Paulo, curso de pós-graduação em ensino de ciências - USP, 2002. Dissertação de Mestrado.

SWINBANK, E. Particle Physics: a new course for schools and colleges. Physics Education, v. 27, n. 2, p. 87-91, mar. 1992.

TERRAZZAN, Eduardo A. A inserção da Física Moderna e Contemporânea no Ensino de Física na escola de $2^{\circ}$ grau. Caderno Catarinense de Ensino de Física. Florianópolis, V.9, n.3, p.209-214, dez.1992.

. Perspectivas para a inserção de física moderna na escola média. São Paulo: curso de pós-graduação em educação - USP, 1994 Tese.

TERRAZZAN, Eduardo A., et al. A evolução das idéias sobre a estrutura da matéria: uma contribuição para o ensino de Física. Atas: XII Simpósio Nacional de Ensino de Física, Belo Horizonte, p.650-658, jan. 1997.

TIPLER, Paul A.; LLEWELlYN, Ralph A. Física Moderna. $3^{\text {a }}$ ed. Rio de Janeiro: LTC, 2001.

VARELA, João. O século dos quantas. Lisboa: Gradiva, nov 96.

Sites:

http://cienciahoje.uol.com.br. Acesso em 21/07/2005

http://microcosm.web.cern.ch/Microcosm/esp/welcom.html . Acesso em 21/07/2005 
http://www.aventuradasparticulas.ift.unesp.br/. Acesso em 21/07/2005

http://www.cbpf.br/Publicacoes.html. Acesso em 21/07/2005

http://www.pbs.org/wgbh/aso/tryit/atom/. Acesso em 21/07/2005 


\author{
Universidade de São Paulo \\ Instituto de Física - Instituto de Química \\ Instituto de Biociências - Faculdade de Educação
}

\title{
Do Visível ao Indivisível: uma proposta de Física de Partículas Elementares para o Ensino Médio
}

\author{
Maxwell Roger da Purificação Siqueira
}

\section{ANEXOS}

Orientador: Prof. Dr. Maurício Pietrocola

Dissertação de mestrado apresentada ao Instituto de

Física, ao Instituto de Química, ao Instituto de Biociências e a Faculdade de Educação da Universidade de São Paulo, para a obtenção do título de Mestre em Ensino de Ciências.

Comissão Examinadora:

Prof. Dr. Maurício Pietrocola (USP)

Prof. Dr. Frederico Firmo de Souza Cruz (UFSC)

Profa. Dra. Jesuína Lopez de Almeida Pacca (USP)

São Paulo 
O material de Física de Partículas Elementares está dividido em sete blocos, compostos pelos seguintes recursos didáticos.

- Texto de apoio: material para embasamento teórico e aprofundamento.

- Experiências: atividades experimentais com roteiros de preparação e aplicação.

- Teste seus conhecimentos: questões e problemas para sistematização do conteúdo.

- Multimídia: simulações virtuais com o intuito de apresentar experimentos, funcionamento de equipamentos e fenômenos que não podem ser apresentados em sala de aula.

Abaixo, é apresentado resumidamente o conteúdo e recursos utilizados em cada bloco:

\section{BLOCO I - RAIOS-X E OUTRAS RADIAÇÕES}

Nesse bloco é discutido a descoberta dos Raios-X, a partir das experiências com tubos de raios catódicos, que trouxe questões que levaram a descoberta de outras radiações e da radioatividade, dando início a busca pelos constituintes do átomo.

\section{Recursos didáticos}

\section{Textos de apoio}

- Vendo através da pele: a descoberta dos Raios-X

- A descoberta da radioatividade

- Entra em cena uma nova figura: Ernest Rutherford

\section{Experiência:}

- Atividade 0: Falando sobre o que é fundamental

Esta atividade introduz o estudo no campo das partículas elementares e interações fundamentais. Ela tem o intuito de desafiar as concepções das pessoas acerca dos fundamentos da física dessa área e não avaliar o conhecimento delas sobre a área.

- Atividade 1: Radiografias

Essa atividade tem o intuito de discutir um pouco as radiografias e o processo dos raios $\mathrm{X}$, sendo a porta de entrada para iniciar a caminhada sobre o fantástico mundo da Física de Partículas. Faz-se uso também de uma atividade com analogia com o papel fotográfico para melhor visualização e apreensão do que está sendo discutido.

- Vídeo da TV Ontário: a descoberta da radioatividade

\section{Teste seus conhecimentos}

- O que são os raios-X? Como são produzidos? E quais seus efeitos?

- Nas radiografias, os contornos dos ossos aparecem bastante claros, sobre o fundo escuro, bem como o contorno de objetos e pessoas (Fig. 3 e 4). Analisando o processo de absorção dos raios X, estas regiões mais claras, recebem mais ou menos raios $\mathrm{X}$ do que as outras? Explique sua resposta.

- Qual é o significado da palavra radioatividade dada por Marie Curie? 


\section{BLOCO II - ORDEM DE GRANDEZA E MODELOS ATÔMICOS}

Nesse bloco pretende-se aprofundar a idéia da ordem de grandeza e das dimensões utilizadas, já que será estudado o mundo microscópico, onde esses conceitos serão muito utilizados, para que dessa forma possa ter uma idéia melhor das dimensões tratadas nessa área.

Discutir a evolução da idéia de átomo desde os gregos até Bohr, mostrando como as descobertas de novas partículas modificaram a imagem da natureza e novas questões apareceram, levando as novas investigações, originando novas áreas de investigação: a Física Nuclear e a Física Atômica.

\section{Recursos didáticos}

\section{Textos de apoio}

- A queda do status elementar do átomo: a descoberta do elétron

- A busca pelo constituinte da matéria: a evolução do conceito de átomo.

- A descoberta de Rutherford: Um novo modelo atômico

\section{Experiência:}

- Atividade 2:

$1^{\text {a }}$ parte - ordem de grandeza

Essa atividade tem o intuito de tentar fazer o aluno compreender um pouco sobre as ordens das grandezas medidas em Física de Partículas, já que se trata de uma área que investiga o mundo subatômico.

$2^{\mathrm{a}}$ parte - enxergando o invisível

Essa parte tenta trabalhar com a imaginação do aluno, buscando um pouco de visualização dos objetos que não podem ser visto a olho nu, como é o caso das moléculas, átomos e partículas. Para tanto utilizamos a animação que se encontra no site:

http://microcosm.web.cern.ch/microcosm/P10

- Atividade 3: espalhamento Rutherford

Nesta atividade usam-se os métodos desenvolvidos por Ernest Rutherford no começo de 1900, e que, ainda são usados em nossos dias pelos físicos de partículas, em seus experimentos com aceleradores. Estes métodos permitem aos cientistas identificar as características de partículas que realmente não podem ser vistas. Mostrando o quanto boa devem ser as medidas, quando não se pode enxergar o que está sendo investigado.

\section{Teste seus conhecimentos}

- Algumas pessoas afirmam que todas as coisas são possíveis. É possível que o núcleo de Hidrogênio emita uma partícula $\alpha$ ? Justifique sua resposta.

- Destaque as principais diferenças entre os modelos de Rutherford e de Bohr.

- Por que na experiência de Rutherford a maioria das partículas $\alpha$ atravessam a folha sem sobre nenhum desvio?

- Como você pode confirmar a forma dos objetos sem olhá-los? 


\section{BLOCO III - A INTERAÇÃO FORTE}

Nesse bloco procura-se discutir como a descoberta do nêutron, comprometeu a estabilidade do núcleo, mostrando haver uma incompatibilidade, sendo necessário buscar uma solução para resolver esse impasse. Isso levou a uma hipótese da existência de uma nova força existente no núcleo de intensidade maior do que a repulsão eletromagnética - a força forte - Confirmada com as contribuições de um físico brasileiro (César Lattes), através da descoberta do méson $\pi$,

Discuti-se ainda: as propriedades dos quarks e de que maneira eles interagem no interior das partículas; o que são os raios cósmicos, como funcionam os aceleradores de partículas e a câmara de bolhas; a compreensão da radiação $\alpha$.

\section{Recursos didáticos}

\section{Textos de apoio}

- A solução de um problema: a descoberta de nêutron

- Entendendo a estabilidade do núcleo: a força Forte

- Entendendo a radiação $\alpha$

- Aceleradores de partículas

- César Lattes e o méson $\pi$

- Os constituintes do núcleons: o modelo de quarks

\section{Experiência:}

- Atividade 4: entendendo o funcionamento dos aceleradores de partículas

Essa atividade procura simular o funcionamento dos acelerados de partículas, mostrando os princípios básicos de funcionamento. Essa simulação se encontra no site: http://microcosm.web.cern.ch/microcosm/RF_cavity/ex.html

- Site com simulação dos raios cósmicos:

Essa atividade tem o intuito de mostrar como ocorrem os raios cósmicos na atmosfera. A simulação se encontra no site: www.lip.pt/experiments/trc/opsao/oqsao3.html

- Atividade 5: O modelo dos quarks

Essa atividade tem como objeto levar ao entendimento que algumas partículas são constituídas por outras partículas ainda menores - os quarks - como é o caso dos prótons e nêutrons. Compreendendo também a hipótese de uma nova carga - carga cor - através da violação do princípio da exclusão de Pauli.

- www.pbs.org/wgbh/aso/tryit/atom (atom build ) - Simulação dos constituintes das partículas, os quarks, através da formação de alguns átomos.

\section{Teste seus conhecimentos}

- Um par de prótons de um núcleo atômico se repelem, mas também se atraem. Explique isso.

- É razoável pensar, que em um intervalo de tempo muito pequeno existam somente prótons ou somente nêutrons dentro do núcleo? Explique sua resposta. 


\section{BLOCO IV - A INTERAÇÃO FRACA}

Discutir as idéias que levaram a descoberta do neutrino e o que isso implicava para física na época, mostrando a suas propriedades. Com base nessa descoberta foi feita a formulação da interação fraca, que atua no interior das partículas, modificando o sabor dos quarks. Com isso pode-se entender o processo da radiação $\beta$.

\section{Recursos didáticos}

\section{Textos de apoio}

- A descoberta do neutrino: uma nova interação

\section{Teste seus conhecimentos}

- Se os neutrinos são partículas que têm a massa muito próxima de zero, como foi feito para serem detectados?

- Através do processo da força fraca, esquema acima, tente explicar a reação:

$$
\Lambda^{0} \rightarrow \pi^{-}+\mathrm{p}
$$




\section{BLOCO V - PARTÍCULAS E ANTIPARTÍCULAS}

Mostrar a hipótese das antipartículas proposta por Dirac, que mais tarde foi detectada e como houve uma mudança na maneira de pensar o vácuo. Discutir como é o processo de aniquilação e produção das partículas e antipartículas.

Discutir a necessidade de as novas leis de conservação para partículas, como $\mathrm{n}^{\circ}$ bariônico e $\mathrm{n}^{\mathrm{o}}$ leptônico, e ainda o comportamento estranho de algumas partículas (estranheza).

\section{Recursos didáticos}

\section{Textos de apoio}

- As antipartículas: a descoberta do pósitron

- Partículas estranhas: as novas leis de conservação

\section{Experiência:}

- Atividade 6: a regra do jogo.

Fazer com que se compreenda que as leis de conservação se obtêm de tal modo a poder explicar o que é observado e que não é, e são chamadas leis somente depois que muitas provas vão confirmar sua validade.

- Atividade 7: analisando o sistema

Mostrar o método universal de analisar um sistema em função de seus componentes e de suas interações. Mostrando uma analogia com a busca dos constituintes elementares e suas interações.

\section{Teste seus conhecimentos}

- Os antiprótons quase sempre são aniquilados na reação $p+\bar{p} \rightarrow \gamma+\gamma$. Suponha que um próton e um antipróton se aniquilem em repouso. Por que devem ser produzidos dois fótons em vez de apenas um?

- Qual deve ser a energia mínima do fóton para que a seguinte reação ocorra: $\gamma \rightarrow \Lambda^{+}+\pi^{-}$

- O que são as partículas conhecidas como estranhas? Quais as características que elas apresentam? 


\section{BLOCO VI - OS CAMPOS QUANTIZADOS}

Através da descrição feita para a interação forte e fraca, buscaremos fazer uma descrição similar para o campo eletromagnético e o campo gravitacional, mostrando como são descritas essas interações quanticamente e quem são seus quantas.

\section{Recursos didáticos}

\section{Textos de apoio}

- Teoria quântica de campos: uma nova concepção do campo eletromagnético

- Diagramas de Feynman: uma nova maneira de ver as interações

\section{Experiência:}

- Atividade 8: A troca de fótons entre partículas.

Essa atividade tentará descrever, através de uma analogia, o papel do fóton na interação eletromagnética, no âmbito da teoria quântica de campos, ou seja, com o campo quantizado.

\section{Teste seus conhecimento}

- Qual a importância dos fótons dentro dessa "nova" forma de descrever a interação eletromagnética? 


\section{BLOCO VII - AS FAMÍLIAS DAS PARTÍCULAS}

Montar a grande estrutura coerente das partículas classificando-as, através dos mediadores das interações e de algumas propriedades. Expondo também o modelo padrão atual.

\section{Recursos didáticos}

\section{Textos de apoio}

- Propriedades das partículas

- As famílias das partículas

\section{Experiência:}

- Atividade 9: montagem de um mapa conceitual

Essa atividade encerra nosso passeio pelo mundo da Física de Partículas. Nela, tentaremos sistematizar algumas idéias que podem ter ficando soltas ao longo do caminho. Por isso tentaremos montar esse mapa conceitual, que irá auxiliar na compreensão dos conceitos estudados.

- Visita ao Pelletron (acelerador de partículas do IFUSP)

\section{Teste seus conhecimentos}

- Existem maneiras de diferenciar partículas com mesma carga e mesma massa? Qual? 


\section{Vendo através da pele: a descoberta dos Raios-X}

Há pouco mais de 100 anos atrás, não era possível o médico visualizar o interior do corpo humano sem ter que abrí-lo e isso dificultava muito o diagnostico de doenças e fraturas nos pacientes. Mas em 1895 uma grande descoberta revolucionou a humanidade, principalmente a física e a medicina, nesse ano eram descobertos os raios X. Mas como isso ocorreu?

$\mathrm{Na}$ noite de 8 de novembro de 1895 o físico holandês Wilhelm Conrad Röntgen (1845-1923), seguindo as tendências de sua época, estava fazendo mais uma experiência com descargas elétricas nos tubos de raios catódicos (figura 1), estudando o fenômeno da luminescência produzida pelos raios no tubo. Quando notou que algo de diferente acontecia. Em sua sala de experiências totalmente às escuras, ele viu a folha de

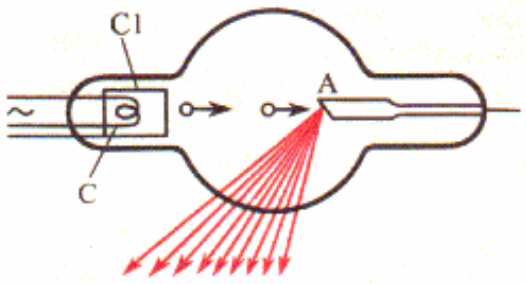

Figura 1 papel, usada como tela e tratada com uma substância química fluorescente (platinocianeto de bário), colocada a uma certa distância do tubo brilhar emitindo luz.Röntgen espantado, pode imaginar que alguma coisa devia ter atingido a tela para que ela reagisse dessa forma. Mas o tubo de raios catódicos estava coberto por uma cartolina negra e nenhuma luz ou nenhum raio catódico poderia ter escapado dali.

Surpreso e perplexo com o fenômeno, ele decidiu pesquisá-lo mais a fundo. Virou a tela, de modo a que o lado sem a substância fluorescente ficasse voltado para o tubo; mesmo assim, a tela continuava a brilhar. Ele então afastou a tela para mais longe e o brilho persistiu. Depois, colocou diversos objetos (uma camada de papelão, pedaços de madeira, um livro de 1000 páginas e até finas placas metálicas) entre o tubo e a tela e todos pareceram transparentes. Quando sua mão escorregou em frente à válvula ele viu os ossos na tela (figura 2). Descobrira "um novo tipo de raio", conforme ele mesmo explicou em sua primeira publicação.

Röntgen havia ficado tão perplexo com sua descoberta, que teve que se convencer primeiro antes de falar com qualquer pessoa sobre sua descoberta do novo tipo de raio. Trabalhou sozinho durante sete semanas nessa tentativa, quando finalmente estava convencido, registrou sua descoberta (imagem da mão) em chapas fotográficas, e só então passou a ter certeza.

Em $1^{\circ}$ de janeiro de 1896 , ele distribui o relatório preliminar de sua descoberta, o que causou grande agitação, mas sua descoberta não podia ser refutada facilmente, pois havia fotografias dos raios $\mathrm{X}$ de suas mãos anexadas nele. No decorrer do mês, a notícia havia se espalhado por todo o mundo. Pode-se imaginar o deslumbramento em relação a esses raios aos quais

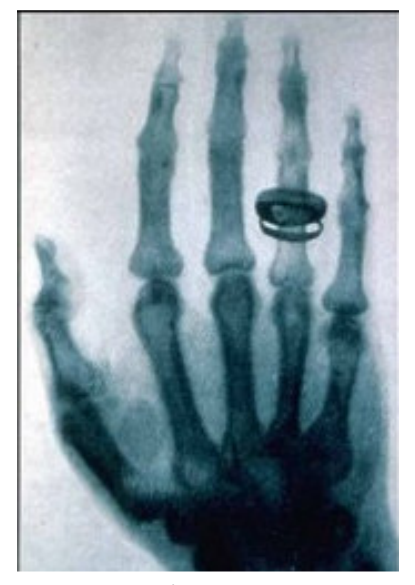

Figura 2 tudo se tornava transparente e por meio dos quais todos podiam ver seus próprios ossos. Pode-se ver praticamente os dedos sem os músculos, mas com anéis, como se podia ver também uma bala alojada no corpo. As conseqüências para a medicina foram imediatamente percebidas. Imagine você nessa época, podendo ver os seus ossos, sem qualquer corte ou perfuração. Somente assim terá idéia da revolução causada com essa descoberta.

$\mathrm{O}$ trabalho de Röntgen sobre os raios $\mathrm{X}$ foi perfeito à luz do conhecimento existente em sua época. Mas ele, não conseguiu entender a natureza dos raios $X$, ou seja, ele não conseguiu comprovar que se tratava de uma radiação eletromagnética. No entanto, ele conseguiu mostrar que os raios podiam atravessar materiais sólidos, podiam ionizar o ar, não sofriam reflexão no vidro e não eram desviados por campos magnéticos, mas não 
conseguiu observar os fenômenos da refração e da interferência normalmente associados a ondas (ondas eletromagnéticas, neste caso) por isso ficou o nome enigmático de raios $\mathrm{X}(\mathrm{X}$ é o símbolo pra nomear o desconhecido)

Mais tarde sua natureza foi desvendada, mostrando que eles eram consequiência da colisão dos raios catódicos com a parede do tubo e, por terem comprimento de onda muito pequeno, Röntgen não podia observar os fenômenos necessários para comprovar que os raios-X são ondas eletromagnéticas (radiação eletromagnética) de alta frequiência.

Uma ilustração do equipamento de Röntgen é mostrado ao lado. Entre os catodos do tubo de vidro, os raios catódicos são inicialmente acelerados, com voltagem de até 100 KV (100.000 V) e, em seguida, são bruscamente freados (há uma colisão dos raios e o alvo). Por causa disso, ocorre uma emissão de radiação eletromagnética com um comprimento de onda muito pequeno (da ordem de $10^{-12} \mathrm{~m}$ ), que corresponde a radiações

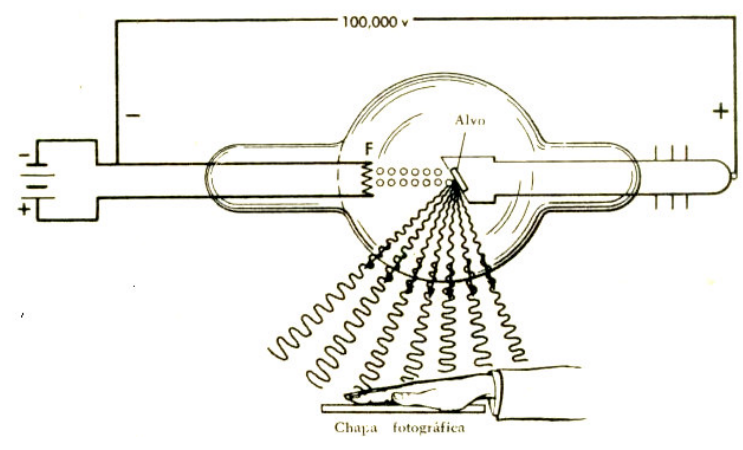
de alta freqüência. É assim que são produzidos os raios $\mathrm{X}$.

As aplicações dos raios X são as mais diversas possíveis. Elas vão desde "simples" obtenção de chapas fotográficas (radiografias) para detectar uma fratura, uma inflamação e uma cárie até a determinação de uma certa porcentagem de uma substância em um composto, através da difração dos raios X, como é o caso da quantidade de carbono existente no aço. Essa determinação é importante, pois permite que o aço fique mais maleável e conseqüentemente consegue-se produzir chapas mais finas.

Atualmente, os raios $\mathrm{X}$ também são utilizados na área de segurança, como é o caso dos aeroportos. Com eles, é possível "ver" dentro das malas e constatar se existem objetos metálicos e até mesmo se as pessoas carregam algum tipo de arma (figura 3). Sua utilização também pode ser vista na fronteira dos E.U.A com o México, onde a polícia o utiliza para vasculhar o interior dos veículos (figura 4).

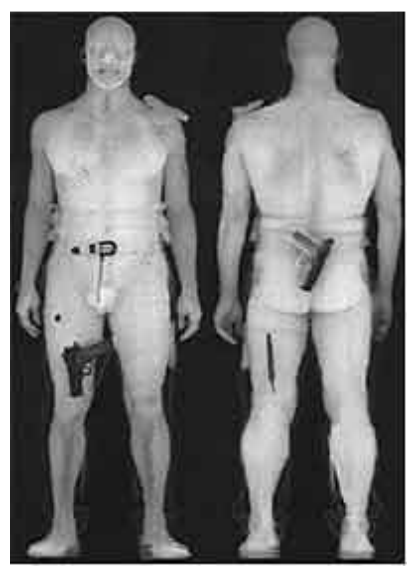

Figura 3

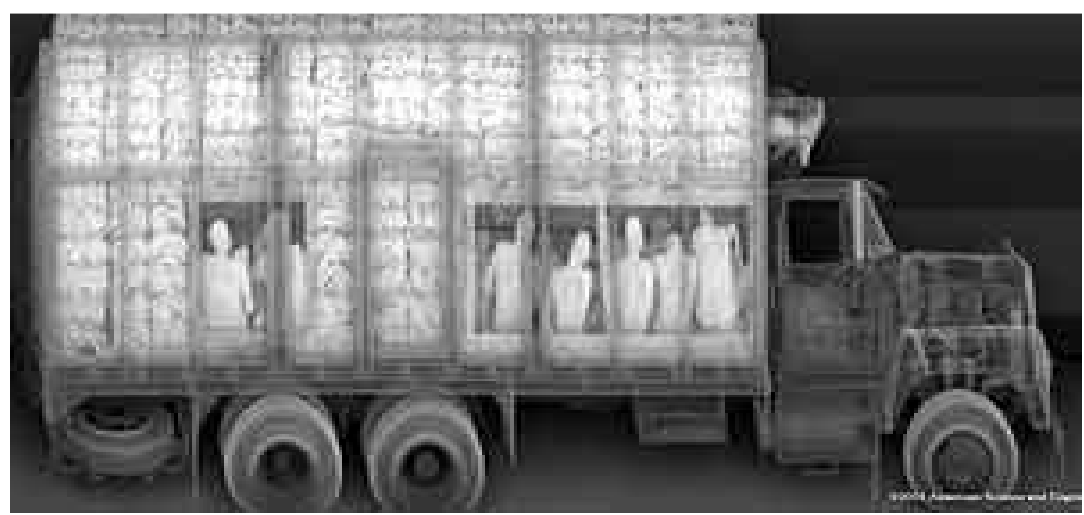

Figura 4 
Questões:

1) Sabemos que os raios $X$ são invisíveis a olho nu. Com base nisto, discuta com seus colegas, outras formas de se detectar os raios $\mathrm{X}$, que não usem chapas radiográficas (lembre que os raios $\mathrm{X}$ podem ionizar o ar, ou seja, retirar elétrons dos átomos).

2) Nas radiografias, os contornos dos ossos aparecem bastante claros, sobre o fundo escuro, bem como o contorno de objetos e pessoas (Fig. 3 e 4). Analisando o processo de absorção dos raios $\mathrm{X}$, estas regiões mais claras, recebem mais ou menos raios $\mathrm{X}$ do que as outras? Explique sua resposta.

3) Que semelhanças e diferenças têm os raios $X$ e a luz visível?

4) Como você imagina os diagnósticos médicos se os raios $X$ não tivessem sido descobertos? O que os médicos fariam para perceber se você tem uma infecção ou um osso rachado? 


\section{Aspectos do Campo Eletromagnético}

Ao aproximarmos um ímã de um pedaço de certo metal pendurado por um fio, vemos que este é "puxado" pelo ímã. Se pegarmos agora um canudinho e atritarmos com uma lã ou papel higiênico, ele ficará carregado eletricamente. Aproximando o canudinho de uma bola de isopor pequena, pendurada por um fio isolante ela será "puxada" pelo canudinho. Vemos assim que a bolinha sente a presença do canudinho, bem como aquele metal sente a presença do ímã, mesmo sem ter contato. Mas como pode um objeto sentir a presença do outro sem haver contato? Como eles não têm olhos, de que forma eles sabem que há um outro corpo por perto que os atrai?

Para responder essa questão, utilizamos o conceito de campo. Ele surgiu na primeira metade do século XIX para explicar fenômenos parecidos a estes. Nesses fenômenos, temos um campo elétrico (associado às cargas do canudinho) e um campo magnético (associado ao ímã). Esses campos são semelhantes ao campo gravitacional que estamos mais familiarizados. Mas afinal o que são esses campos?

Ele é algo que está ao redor dos corpos (estendendo-se até o infinito, porém sua intensidade diminui com a distância). Podemos entendê-lo como sendo uma "aura" (algo sutil e tênue envolvendo o corpo) que preenche o espaço em volta deles. Para cada um dos campos existe um ente responsável associado a sua presença. No caso do campo elétrico e magnético é a carga elétrica e, no caso do gravitacional é a massa. Dessa forma, não temos carga elétrica e massa sem campo e vice-versa. Devemos destacar ainda, que o campo existe independente da presença de outras cargas elétricas ou massa nas vizinhanças, podendo ser representado como algo contínuo que se estende até o infinito em todas as direções.

No entanto, o interesse aqui é estudar o campo elétrico e magnético, deixando a discussão do campo gravitacional para outra ocasião. A intensidade do campo elétrico decresce com o aumento da distância em relação à carga, como podemos observar na figura 1. No entanto, essa não é a única maneira que temos para representá-lo. A figura 2 mostra as linhas de campo de uma carga elétrica positiva, representado o campo elétrico dessa carga.

No caso do canudinho, devido ao desequilíbrio das cargas elétricas causado pelo atrito com a lã ou papel higiênico, a ação desse campo "puxa" a bolinha. Essa ação é conhecida como força elétrica ou interação elétrica. Assim, é graças ao campo elétrico e magnético que a bolinha sente a presença do canudinho e o metal a presença do ímã.

A maneira como uma carga elétrica comunica ou interage com outras cargas pode ocorrer de duas formas: atração ou repulsão. Isso ocorre devido ao sinal que as cargas elétricas podem ter, isto é, positiva $(+)$ ou negativa (-). Quando as cargas têm o mesmo sinal ocorre à repulsão e quando forem de sinais contrários, ocorre a atração.

Assim, as cargas elétricas no espaço, sentem a Figura 1: representação do campo elétrico de uma carga elétrica $\mathbf{q}$

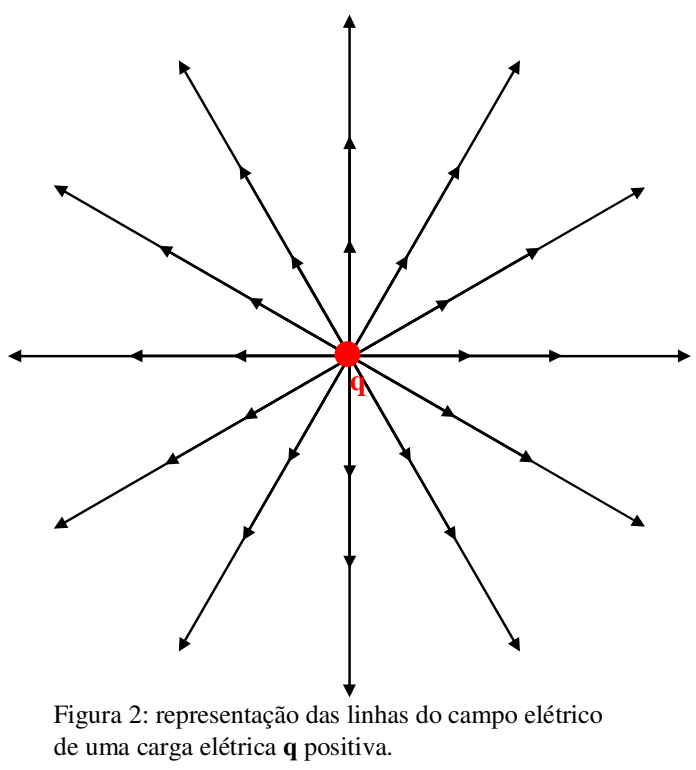
presença do campo uma da outra e se interagem, como aconteceu com as cargas do canudinho e da bolinha. 
Desta forma, podemos dizer que o campo elétrico é algo sutil, tênue, real, que não pode ser visto, nem tocado e envolve a carga elétrica, comunicando a sua presença a outras cargas a sua volta. Dependendo do sinal das cargas elétricas envolvidas, essa comunicação ocasiona uma atração ou a uma repulsão.

Isso tudo pode parecer muito novo ou estranho, mas a interação eletromagnética está presente ostensivamente em nosso cotidiano: nas reações químicas, na luz que recebemos do Sol, na televisão e mais ainda, ela é a responsável pela formação dos aglomerados que constitui a matéria. A matéria da cadeira que você está sentado agora se mantém coesa devido à interação eletromagnética, o mesmo acontecendo com os átomos que formam a água que você bebeu hoje.

Contudo essas são descrições de campos elétricos e magnéticos associados à carga e ímã em repouso. O que aconteceria com esse campo se a carga ou o ímã fossem movimentados? Ele vai junto nesse movimento?

\section{As ondas eletromagnéticas}

Já comentamos que os campos elétrico e magnético estão intimamente relacionados através da carga elétrica. Já sabemos que uma carga elétrica interage com a outra devido aos seus campos elétricos e um ímã interage com um metal ou um outro ímã através de seu campo magnético. Mas como esses dois campos se relacionam?

É mais ou menos assim: quando a carga se movimenta, o seu campo elétrico se movimenta junto, pois ele é indissociável da carga. Ao entrar em movimento, o seu campo elétrico, em qualquer ponto do espaço varia. Porém, quando o campo elétrico sofre essa variação, ele acaba gerando um campo magnético. Com isso, quando uma carga elétrica varia o seu estado de repouso, ela arrasta junto o seu campo elétrico, que por ser variável, gera (induz) um campo magnético também variado, que por sua vez, gera um campo elétrico variado e assim por diante.

Essa alternância de campos elétricos e magnéticos variados se propaga por todo o espaço, levando a informação de que a carga elétrica se movimentou ou está em movimento. A propagação dessa informação é o que chamamos de ondas eletromagnéticas ou radiação eletromagnética.

As ondas eletromagnéticas têm origem no movimento de uma carga elétrica, que quando acelerada ou desacelerada, faz seu campo elétrico variar que, conseqüentemente gera um campo magnético variado e assim sucessivamente, levando a informação desse movimento aos pontos do espaço. Essa propagação é feita na velocidade da luz $\boldsymbol{c}^{52}$, característica mostrada por J. C. Maxwell (1831-1879), unindo a luz aos fenômenos eletromagnéticos.

Como toda onda, a onda eletromagnética tem a frequiência como uma característica bem destacada, por que é através dela, que as ondas eletromagnéticas são classificadas. A unidade de medida da frequiência é o $\boldsymbol{H e r t z}-\boldsymbol{H z}$, em homenagem a Heinrich Rudolph Hertz (1857-1894), devido à descoberta das ondas de rádio. Para cada faixa de freqüência, usamos um termo diferente para descrevê-la. Por exemplo, a freqüência que vai de $4 \times 10^{14} \mathrm{~Hz}$ até $7 \times 10^{14} \mathrm{~Hz}$ é o que chamamos de luz visível. Já as ondas de rádio estão na faixa de $10^{4} \mathrm{~Hz}$ até $10^{6} \mathrm{~Hz}$.

A freqüência é a medida das oscilações que a carga elétrica executa por unidade de tempo, isto é, se a freqüência de uma onda eletromagnética é de $10^{5} \mathrm{~Hz}$, ela oscila 100000 vezes a cada segundo. Esse conceito é bem parecido com a freqüência escolar, que indica quantas vezes os alunos vêm à aula durante um bimestre.

Abaixo a tabela mostra algumas frequiências para cada tipo diferente de onda eletromagnética:

\begin{tabular}{cccc}
\hline $\mathrm{f}(\mathrm{Hz})$ & Tipo de onda & Detecção & Exemplos de Fontes \\
\hline $10^{21}$ & raios $\gamma$ & cintiladores & materiais radioativos \\
\hline
\end{tabular}

\footnotetext{
${ }^{52}$ Aproximadamente $300.000 \mathrm{~km} / \mathrm{s}$.
} 


\begin{tabular}{cccc}
\hline $10^{19}$ & raios X & chapa fotográfica & tubos de raios X \\
$10^{16}$ & ultravioleta & chapa fotográfica & laser \\
$7 \times 10^{14}$ & violeta & olhos & arcos elétricos \\
$4 \times 10^{14}$ & vermelho & olhos & arcos elétricos \\
$10^{13}$ & infravermelho & termômetros & lâmpadas \\
$10^{5}$ & rádio & circuitos eletrônicos & circuitos eletrônicos \\
\hline
\end{tabular}

\section{Questões:}

1) Como um ímã percebe a proximidade de outro ímã, mesmo sem haver contato?

2) Quais os tipos de campos estudados e quais os entes responsáveis por eles?

3) Como as ondas eletromagnéticas são produzidas?

4) Quais são as semelhanças e diferenças entre os raios $X$ e a luz visível?

5) Depois de ter lido e discutido a respeito do campo eletromagnético ou interação eletromagnética e visto a sua importância, faça uma análise de como seria o mundo e o Universo sem essa interação.

\section{Questões complementares}

1) Duas cargas $q_{1}$ e $q_{2}$ sofrem atração a distância através do campo elétrico gerado por elas. $O$ que podemos dizer sobre o sinal dessas cargas? Até onde se estende o campo elétrico de $\mathrm{q}_{1}$ ? Se de repente $\mathrm{q}_{2}$ sumisse como ficaria o campo elétrico de $\mathrm{q}_{1}$ ? Ele sumiria também ou continuaria existindo?

2) Antes do canudinho ser atritado, a) Existia um campo elétrico nele? b) O que aconteceu depois do atrito?

3) Como uma carga elétrica pode gerar campo magnético ou ondas eletromagnéticas? 


\section{A descoberta da radioatividade}

No dia 20 de janeiro de 1896, Antoine Henri Becquerel (1852-1908) tomou conhecimento da descoberta dos raios-X por Röntgen. Físico francês da terceira geração da família Becquerel, tinha muito interesse na fosforescência e na fluorescência dos materiais. Estes termos, fosforescência e fluorescência, não são sinônimos. Na fluorescência a emissão luminosa ocorre enquanto houver estímulo, a absorção e a emissão ocorrem rapidamente. $\mathrm{Na}$ fosforescência, mesmo cessado o estímulo, haverá a emissão, pois o processo de emissão é mais lento que na fluorescência.

Becquerel imaginou se havia uma relação entre raios $X$ e a fluorescência, ou seja, se algumas substâncias fluorescentes poderiam emitir raios $\mathrm{X}$ espontaneamente. Depois de descobrir que muitos elementos não produziam qualquer efeito, passou a utilizar materiais fosforescentes.

Ele utilizou sulfato de potássio e urânio, sal de urânio que era conhecido por suas propriedades fosforescentes. Cobriu uma chapa fotográfica com duas folhas de papel escuro grosso, tão grosso que a chapa não ficou manchada ao ser exposta ao Sol durante um dia inteiro. Colocou sobre o papel uma camada da substância

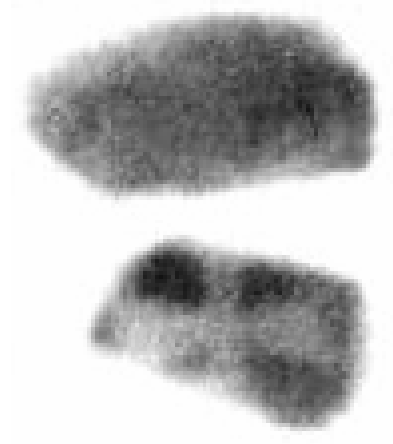
fosforescente e para ativar a fosforescência do sal de urânio, e expôs tudo ao Sol por várias horas. Quando revelou a chapa fotográfica, percebeu a silhueta da substância fosforescente em escuro sobre o negativo. Concluiu que a substância emitia radiações capazes de atravessar a folha de papel opaca à luz. Tudo se passava como se o sal de urânio emitisse raios-X.

Em 24 de fevereiro de 1896, Henri Becquerel fez um relatório de sua experiência e apresentou à Academia de Ciências em Paris. No entanto, em 2 de março, Becquerel anunciava aos seus pares da academia algo mais extraordinário. Durante a semana havia tentado repetir a experiência, preparando uma nova placa fotográfica enrolada no papel e no sal de urânio. Aconteceu que o tempo havia piorado e ele ficou impossibilitado de realizar a exposição ao Sol. Então guardou o conjunto numa gaveta à espera de melhores dias. Na véspera da seção da academia, como o tempo permaneceu encoberto, decidiu, mesmo assim, revelar as placas, esperando encontrar o negativo em branco. Para sua surpresa os negativos mostravam uma mancha de grande intensidade. Conclui que o sal de urânio emitia raios capazes de atravessar o papel preto, quer tivesse sido exposto ou não ao Sol. Sem dúvida, alguma emissão desconhecida estava saindo do sal, atravessando o papel e chegando até a chapa fotográfica. Essas emissões foram chamadas de raios de Becquerel.

Pouco tempo depois, em 9 de março de 1896 já descobrira que a radiação emitida pelo sal de urânio não apenas escurecia as chapas fotográficas protegidas, como também ionizava gases, isto é, provocava a libertação de elétrons dos átomos do gás, que por esse motivo ficavam carregados positivamente (falta de elétrons), transformando estes gases em condutores de eletricidade. A partir daí, era possível medir a "atividade" de uma amostra simplesmente medindo a ionização que ela produzia.

O instrumento usado para a medição da ionização que o gás sofria era um rústico eletroscópio de lâminas de ouro. Este instrumento é constituído de duas folhas metálicas, neste caso de ouro, finas e flexíveis, ligadas em sua parte superior a uma haste, que se prende a uma placa condutora. Normalmente, as folhas metálicas são mantidas dentro de um frasco vidro transparente e seco, a fim de aumentar a sua sensibilidade e diminuir efeitos do ambiente externo. $\mathrm{O}$ isolante impede a passagem de cargas elétricas da haste para o vidro. Aproximando-se da placa um tubo com o gás ionizado, isto é eletrizado, ocorrerá a indução eletrostática, ou seja: se o gás estiver carregado negativamente, ele repele os elétrons livres da placa para as lâminas de ouro, fazendo com que elas se abram devido à repulsão. Se o gás 
estiver com cargas positivas, ele atrai os elétrons livres das lâminas, fazendo também com que elas se abram, novamente, devido à repulsão. A determinação do sinal da carga do gás em teste, que já se sabe estar eletrizado, é obtida carregando-se anteriormente o eletroscópio com cargas de sinal conhecido. Dessa forma, as lâminas terão uma determinada abertura inicial. Pode-se observar isso nas figuras I (neutro) e II (eletrizado):

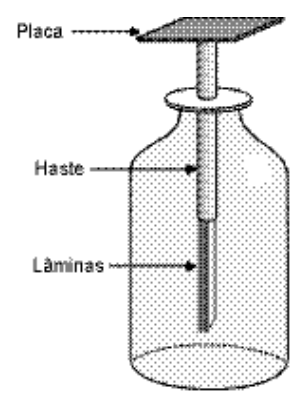

Figura I

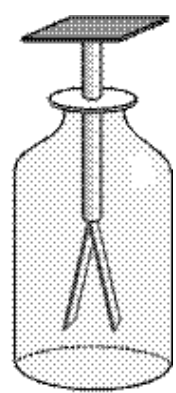

Figura II

A essa altura, um casal de cientistas iniciava suas investigações sobre a radioatividade em Paris, estudando vários minérios, uma vez que Henri Becquerel focalizou suas pesquisas somente no urânio. Marie Sklodowska Curie (1867-1934), polonesa, e seu marido francês Pierre Curie (1859-1906), após analisar vários compostos de urânio, verificaram a constatação de Becquerel, confirmando que a emissão de raios é uma propriedade do elemento urânio e assim, decidiram examinar todos os elementos conhecidos. Descobriram que também o tório emitia raios

semelhantes aos do urânio.

Nesse ponto, depois de descobrirem que o urânio não era o único elemento a emitir radiação espontaneamente, Marie decidiu então, analisar todos os minérios naturais e para sua surpresa um mineral de urânio (uranita) era três ou quatro vezes mais radioativo do que se esperava. Desta forma concluiu que um elemento extremamente radioativo deveria existir enquanto impureza nesse minério. Depois de um longo e exaustivo trabalho, em julho de 1898, Marie com a ajuda de seu marido Pierre, conseguiu isolar a impureza e perceberam que se tratava de um novo elemento, que designaram de polônio, em homenagem ao país de origem de Marie, a Polônia.

Ao aprimorar mais os seus métodos de purificação da uranita, o casal Curie, acabou por encontrar, em setembro desse mesmo ano, um elemento altamente radioativo que recebeu o nome de rádio. Marie propôs a palavra radioatividade para esse fenômeno.

Mas apesar de conseguir descobrir mais elementos radioativos, permaneciam dois grandes problemas a serem resolvidos, segundo os Curie: Qual era a origem da energia emitida por esses elementos radioativos? Qual é a natureza das radiações emitidas?

\section{Questões:}

1) Qual foi a principal contribuição que os Curie deram para a radioatividade?

2) Qual o termo mais adequado para designar as lâmpadas que iluminam as salas de aula?

3) Explique a frase "para ativar a fosforescência do sal de urânio, ele expôs tudo ao sol por várias horas".

4) Se na experiência de Becquerel, ele tivesse colocado entre o filme revelador e o sal de urânio uma placa grossa $(\sim 3 \mathrm{~mm})$ de chumbo, conseguiria ver alguma mancha? Por quê? 


\section{Entra em cena uma nova figura: Ernest Rutherford}

Após a descoberta dos raios X e da radioatividade, Ernest Rutherford (1871-1937), cientista nascido na Nova Zelândia, deu contribuições decisivas para a compreensão da natureza das substâncias radioativas e das suas radiações. Rutherford e seu colaborador Joseph John Thomson (1856-1940) dedicavam-se a medir a ionização nos gases provocada pelos raios $\mathrm{X}$ e pelas radiações emitidas pelo o urânio.

Em longo trabalho no laboratório Cavendish, Rutherford percebeu, em 1898, a existência de dois tipos diferentes de radiações emitidas pelo urânio, devido a penetração que tinham na matéria. Os raios que são menos penetrantes ele designou por raios alfa $(\square)$ e, os raios que penetravam mais de raios beta $(\square)$. Além da diferença na penetração na matéria, ele percebeu que os raios alfa e beta eram defletidos para lados opostos quando passavam por uma região com campo magnético. Disso ele pode concluir que eles tinham carga elétrica oposta.

Com o resultado das experiências realizadas por

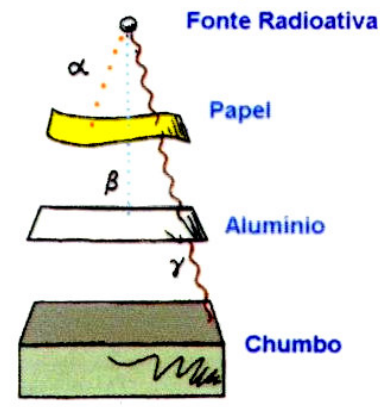
Rutherford, bem como a de outros cientistas como Becquerel, conclui-se em poucos anos que os raios beta ( $\square$ ) são raios catódicos (elétrons). Entretanto, P. V. Villard, na França, descobriu uma terceira forma de radiação que era muito mais penetrante que as duas anteriores, que designou por raios gama. ( $\square$ ). Estes não eram sensíveis ao campo magnético, ou seja, não eram desviados e surgiram como uma espécie de raios X mais energéticos. O esclarecimento da natureza dos raios $\square$ continuou um mistério durante alguns anos.

Ao se mudar para Toronto, no Canadá, Rutherford pode observar outro fenômeno misterioso. Ao isolar a parte radioativa do sal de urânio, ele pode perceber, que com o passar do tempo, ela perdia a sua radiação, em contra partida a solução que havia retirado o elemento radioativo recuperava a radioatividade inicial.

Trabalhando com o químico F. Soddy, Rutherford chegou a um resultado que implicava na transmutação ${ }^{53}$ entre os elementos, algo que foi anunciado com muita

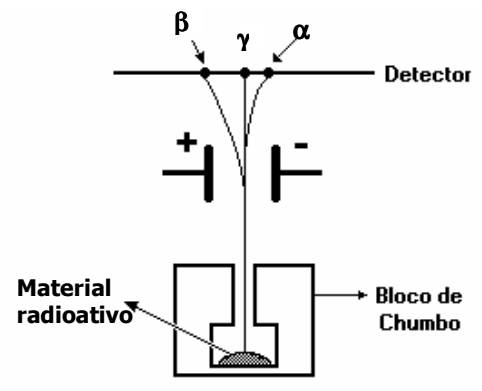
cautela ao anunciar, pois lembrava fortemente o antigo sonho dos alquimistas.

Para fundamentar sua conclusão sobre a transmutação dos elementos, Rutherford teve que investigar mais a natureza das radiações alfa $(\alpha)$. Entre 1900 e 1903, através das medidas da razão entre a massa e carga elétrica das partículas $\alpha$, ele pode concluir que estas são, na verdade, núcleo do átomo de Hélio (He). Resolvendo assim o problema da transmutação dos elementos que pode ser explicado da seguinte maneira: os átomos instáveis (radioativos) emitem as radiações $\alpha$ e $\beta$, ao fazerem isso eles mudam suas propriedades químicas, transformando-se em outro de elemento (transmutação). Estava assim desvendada a natureza das radiações $\alpha$ e da transmutação dos elementos. Mas ainda não compreendiam como que essas radiações eram produzidas, deixando essa questão em aberto para a ciência.

\footnotetext{
${ }^{53}$ A transmutação era o sonho dos alquimistas em transformar qualquer substância em ouro (Ag)
} 


\section{Questões:}

1) a) Qual foi a principal contribuição que Rutherford deu para a radioatividade?

b) Como ele fez isso?

2) Quais são as principais diferenças entre as radiações $\alpha$ e $\beta$ ?

3) Por que a radiação $\gamma$ não sofre desvio ao passar por uma região de campo eletromagnético? 


\section{A queda do status elementar do átomo: a descoberta do elétron}

Na segunda metade do século XIX, o eletromagnetismo já estava praticamente todo formulado com as equações de Maxwell e com a experiência de Hertz que a confirmavam. Na década de 1870, os experimentos com descargas elétricas em gases eram muito realizados e para isso, os cientistas utilizavam tubos de vidro lacrados que se podia retirar o ar de dentro deles.

Um desses cientistas William Crookes era um inglês não muito ortodoxo que acreditava poder se comunicar com os mortos e é mais lembrado hoje pela sua invenção do que veio a ser chamado de "tubo de Crookes", um tubo de vidro lacrado, contendo um gás com densidade muito baixa e dotado de eletrodos em seu interior, próximos a cada uma das extremidades do tubo (pioneiro dos anúncios de néon). $\mathrm{O}$ gás brilha quando os eletrodos eram conectados a uma fonte de tensão. Gases diferentes brilham com cores diferentes, cada gás com uma cor

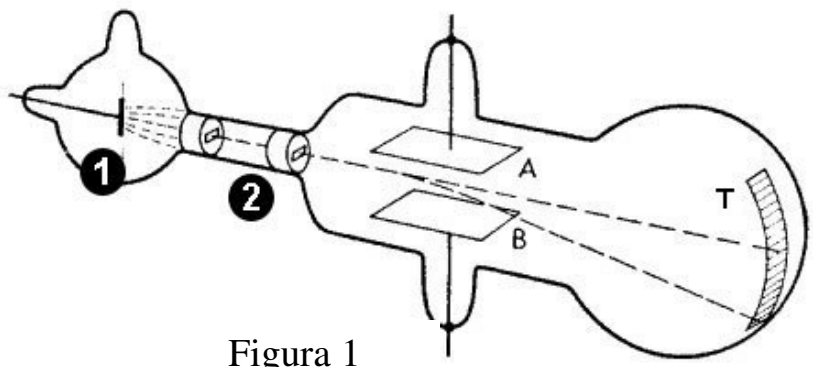
típica. Experimentos realizados com tubos contendo placas metálicas e fendas mostraram que o gás brilhava por causa de algum tipo de "raio" que vinha do terminal negativo( (cátodo). Com a ajuda de colimadores 2 os raios ficavam mais estreitos impedindo que os elétrons atingissem as placas defletoras A e B. Por fim os raios quando incidiam na tela $\mathrm{T}$, pintada com material fosforescente, faziam com que esta cintilasse. $\mathrm{O}$ dispositivo foi chamado de tubo de raios catódicos (figura $1^{54}$ ). Esses raios podiam ser desviados na presença de campos elétricos ou magnéticos. Essa descoberta deu a indicação que os raios poderiam ser formados por partículas negativas.

Em 1897, o físico inglês Joseph John Thomson, influenciado pelos trabalhos de Maxwell e o descobrimento dos raios X, mostrou que os raios catódicos eram de fato formado por partículas, menores e mais leves do que os átomos, que denominou de corpúsculos e todas, aparentemente, eram idênticas. Ele conseguiu criar feixes de raios catódicos bem estreitos, e mediu seu desvio na presença dos campos elétrico e magnético. Thomson raciocinou que o valor do desvio dependia de três coisas: da massa das partículas, da rapidez delas e de suas cargas. Mas como o ângulo de desvio dependeria dessas coisas?

Quanto maior fosse a massa das partículas, maior seria a inércia e menor o desvio sofrido. Quanto maior a rapidez delas, menor seria o desvio. Além disso, a partir dos experimentos, Thomson conseguiu estabelecer que as partículas tinham massa muito menores do que qualquer átomo. A partícula presente nos raios catódicos recebeu o nome de elétron (que significa âmbar em grego). Ele também conseguiu calcular a razão entre a massa e a carga da nova partícula. Devido a esse trabalho recebeu o premio Nobel de 1906.

Em 1907, através de suas experiências, o físico americano Robert Millikan, conseguiu determinar a carga elétrica do elétron. Ele borrifou gotículas de óleo no interior de uma câmara com um campo elétrico que podia ser ajustado (figura $2^{55}$ ). Inicialmente ele notou que algumas gotas moviam-se para cima. Desta forma, ele pode concluir que estas gotículas tinham cargas negativas e sofriam a ação de uma força de

\footnotetext{
${ }^{54}$ Baseada em: http://br.geocities.com/saladefisica9/biografias/thomson.htm

${ }^{55}$ Baseada em: http://www.if.ufrgs.br/ historia/millikan.html
} 
natureza elétrica que superava a gravitacional e por isso elas subiam. Ajustando, então, o campo elétrico dentro da câmara, ele pode manter as gotículas em equilíbrio (flutuando imóveis). Sabendo que a gravidade atuando para baixo era anulada pela força elétrica que atuava para cima, ele percebeu que a carga elétrica de cada gotícula era um múltiplo inteiro de um único valor. Esse valor, ele propôs que fosse uma unidade fundamental para todas as cargas elétricas encontradas na natureza, que era a carga do elétron. Junto com a determinação da razão entre a carga e massa feita por Thomson, Millikan obteve pela primeira vez a massa do elétron, que era cerca de 2000 vezes menor que a massa do átomo mais leve (hidrogênio).

Toda essa investigação e descoberta do elétron levaram a uma nova maneira de olhar os constituintes da matéria. Até então, pensava-se que a matéria era constituída de átomos (algo que não poderia ser

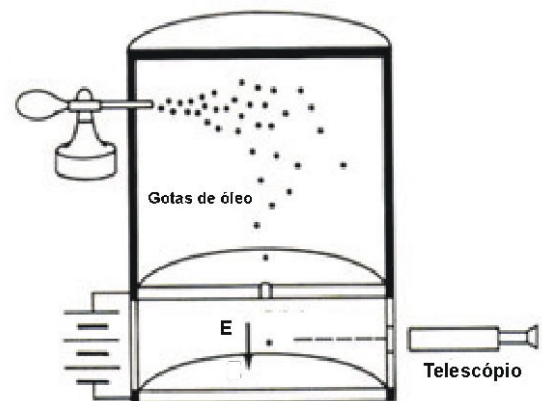

Figura 2 divido, ou seja, algo elementar), com a descoberta do elétron, o átomo perdeu seu status elementar e passou a ser visto de outra forma, o que instigou ainda mais a curiosidade humana na busca do elementar. Fazendo com que novas investigações sobre os constituintes da matéria fossem feitas.

Desta forma, entre 1895 e 1904 os cientistas haviam descoberto e desvendado a natureza dos raios $\mathrm{X}$, da radioatividade, dos raios catódicos e da transmutação dos elementos. Passando por uma grande revolução na maneira de interpretar e ver a natureza.

\section{Questões:}

1) Considerando que os elétrons têm carga negativa como se explica a deflexão ao passar pelo campo elétrico existente entre as placas defletoras?

2) Como verificar a natureza dos raios catódicos? Discuta.

3) Indique uma aplicação para o tubo de raios catódicos. Discuta. 


\section{A busca pelo constituinte da matéria: a evolução do conceito de átomo}

Depois da descoberta do elétron por Thomson, em 1897, a ciência passou por uma grande mudança. Pela primeira vez, estava comprovado que o átomo era composto e não elementar como se pensava antes. Mas como foi a evolução da idéia do átomo?

Tudo começou, há aproximadamente 2500 anos, quando o homem iniciou o seu questionamento sobre a estrutura da matéria, ou seja, qual era a matéria prima ou substância primordial que compunha o Universo. No início das investigações, as concepções filosóficas se dividiam em dois grupos. De um lado, os filósofos que acreditavam que o Universo era formado por um único elemento - monista; por outro, aqueles que acreditavam nos vários elementos que formam o Universo - pluralista.

Dentro da corrente monista, podemos destacar os seguintes filósofos: Tales de Mileto (624 - 546 a.C.), que acreditava que o elemento primordial era a água; Anaxímenes de Mileto (570-500 a.C.) seria o $a r$, uma vez que o mesmo se reduziria a água por compressão. Para Xenófenes da Jônia (570-460 a.C.) era a terra. Porém, Heráclito de Éfeso (540-480 a.C.) era o fogo, o elemento primordial.

Em meados do século V a.C., surge um novo movimento que tenta explicar a matéria prima sendo uma porção única, subdividida em diminutas partes. Essa era a forma como Anaxágoras de Clazômena (500-428 a.C.) imaginava o Universo. Para ele, a matéria prima seria uma espécie de semente (homeomerias) contendo outras sementes em seu interior e, essas, por sua vez teriam outras e assim infinitamente, semente dentro de semente.

Ao contrário da visão de Anaxágoras, Leucipo de Mileto (460-370 a.C.) e seu discípulo Demócrito de Abdera (470-380 a.C.) acreditavam que todas as coisas eram formadas por um único tipo de partícula: o átomo (indivisível, em grego), eterno e imperecível, que se movimenta no vazio. Propunham também, uma explicação para as diversas propriedades das substâncias, através das diferenças geométricas na forma e na posição do átomo.

Paralelamente a essa idéia atomista, tinha-se a corrente pluralista, destacado-se Empédocles de Akragas (490-431 a.C.) que acreditava no Universo formado por quatro elementos: água, terra, fogo e ar, podendo combinar-se para formar as diversas substâncias. Esses elementos estariam em constante movimento que seria intermediado pelo amor ou amizade que os uniam, e do ódio ou inimizade que os separavam.

Mais tarde, Aristóteles de Estagira (384-322 a.C.), propunha outros elementos: frio, quente, úmido e seco, que agrupados de dois a dois, formavam os elementos de Empédocles da seguinte forma: seco e frio daria a terra; seco e quente, o fogo; úmido e quente, o ar e úmido e frio, a água.

Depois de algum tempo, a idéia atomista foi retomada por Epícuro de Samos (341-270 a.C.) e levada as últimas conseqüências por Titocaro de Lucrécio (96-55 a.C.) que acreditava que todos os objetos da natureza eram constituídos de átomos, inclusive o corpo e a alma.

Mas não eram somente os gregos que buscavam a matéria prima do Universo. $\mathrm{Na}$ China, Tsou Yen (360-260 a.C.) tinha uma concepção pluralista, tendo como elementos básicos a água, a madeira, o fogo, o metal e a terra. Porém, não eram meras substâncias, já que eram governados pelo dualismo básico dos princípios cósmicos YIN e YANG.

$\mathrm{Na}$ Índia, os hindus também tinham sua própria concepção, onde os elementos primordiais se ligavam aos sentidos: éter-audição, ar-tato, fogo-visão, água-paladar e terraolfato. Além disso, acreditavam que os quatro elementos de Empédocles eram constituídos de átomos (indivisíveis e indestrutíveis). Por outro lado, devido ao caráter religioso dessa filosofia, havia uma crença que a alma também seria um elemento primordial do Universo.

Já nos primeiros séculos da era cristã, houve uma ascensão do Império árabe. Assim, entre os séculos X e XI, a ciência árabe teve seu período áureo, podendo formular sua própria concepção dos elementos primordiais. Para eles, estes elementos deveriam ser encontrados 
nos princípios ou nas qualidades das substâncias e, não na substância em si. Desta forma, o enxofre seria o princípio da combustão (fogo) e o mercúrio está ligado ao elemento líquido (água).

Depois da queda dos árabes, no final do século XI, as idéias gregas voltaram à tona. Desta forma, as concepções monistas e pluralistas continuaram a ser discutidas e defendidas pelos cientistas da Idade Média e Renascimento.

Entretanto, em 1647, o filosofo e matemático francês Pierre Gassendi (1592-1655) publicou um livro distinguindo pela primeira vez átomo de molécula (distinção estabelecida oficialmente no $1^{\circ}$ Congresso Internacional de Química, em 4 de setembro 1860) e, parecia propor, que o átomo seria uma parte real da substância, porém invisível e indivisível.

Já em 1789, foi editada a primeira tabela periódica contendo 30 elementos, elaborada pelo químico francês Antoine Laurent Lavoisier (1743-1794). Ele se baseava no princípio de que "cada elemento de um composto pesa menos do que o composto como todo".

Alguns anos depois, em 1814, o físico químico Jöns Jakob Berzelius (1779-1848) introduziu a nomenclatura atual dos elementos químicos.

Vários outros cientistas, como o inglês John Dalton (1766-1844), o francês JosephLouis Gay-Lussac (1778-1850) e o italiano Amadeo Avogadro (1776-1856), começaram a investigar melhor as substâncias com a finalidade de determinar as massas dos átomos e seus volumes. Desta forma, foram formuladas algumas leis que ajudaram a classificar melhor as substâncias na tabela periódica.

Foi então, que em 1869 o russo Dimitri Ivanovich Mendeleiev (1834-1907) e em 1870 o alemão Julius Lothar Meyer (1830-1895) chegaram, independentemente, a tabela periódica dos 63 elementos, relacionando o peso atômico com suas propriedades, seguindo a sequiência $2,8,8,18,18,36$ indicando cada período, o número de elementos que apresentavam as mesmas propriedades e assim, Mendeleiev previu a existência de mais alguns elementos que foram detectados posteriormente.

Mas, foi devido às experiências relacionadas ao eletromagnetismo, que o caráter indivisível do átomo foi posto em dúvida. Para o físico francês André Marie Ampère (17751836) e o dinamarquês Hans Christian Oersted (1777-1851), era uma questão de tempo mostrar que o átomo tinha constituintes de carga elétrica. Em 1828, o físico alemão Gustav Theodor Fechner (1801-1887), propôs o modelo de que o átomo consistia de uma parte central massiva que atraia gavitacionalmente uma nuvem de partículas quase imponderáveis. Esse modelo foi melhorando por seu conterrâneo Wilhelm Eduard Weber (1804-1891), colocando a força elétrica no lugar da gravitacional.

A primeira evidência experimental sobre a estrutura do átomo foi verificada pelo físico e químico Michael Faraday (1791-1867) ao descobrir, em 1833, o fenômeno da eletrólise (ação química da eletricidade). Ele observou que a passagem da corrente elétrica através de soluções químicas fazia com que os metais de tais soluções se depositassem nas barras metálicas introduzidas nessas soluções. Essa evidência foi corroborada com a teoria iônica desenvolvida pelo químico Svante August Arrhenius (1859-1927) em 1884, segundo a qual os íons que constituíam a corrente através da solução, nada mais eram do que átomos carregados de eletricidade. 


\section{Uma nova visão do átomo com a descoberta do elétron: o modelo atômico de Thomson}

Com a descoberta do elétron por J. J. Thomson, o átomo não era visto mais como constituinte elementar do Universo. Com isso, Thomson pode propor, em 1903, uma nova visão do átomo.

Seu modelo era descrito da seguinte maneira: o átomo era composto de uma carga positiva uniformemente distribuída em uma esfera de raio da ordem $10^{-10} \mathrm{~m}$, "embebida" de elétrons que vibravam em seu interior. Essa forma garantida a neutralidade do átomo, evitando o colapso do átomo.

O modelo atômico de Thomson também ficou conhecido como o "Modelo do Pudim de Passas", no qual as passas representavam os elétrons e a pasta do pudim, a carga elétrica positiva.

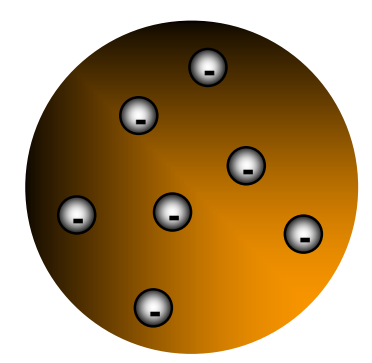

\section{Questão}

1) Que contribuição, o modelo atômico de Thomson, trouxe para a idéia de átomo? 


\section{A descoberta de Rutherford: Um novo modelo atômico}

As experiências com descargas elétricas em gases, também evidenciaram a existência de partículas positivas. Em 1886, Eugen Goldstein (1850-1931), observou que quando o catodo de um tubo era perfurado em forma de canais, certos "raios" atravessavam o próprio catodo em sentido contrário aos raios catódicos e, por isso receberam o nome de raios canais. Nove anos mais tarde, Jean Baptista Perrin (1870-1942), conclui que esses raios eram constituídos de partículas positivas, chegando a ser determinada a razão entre a carga (q) e a massa (m) por Thomson em 1907. Basicamente esses "raios" eram íons de Hidrogênio $\left(\mathrm{H}^{+}\right)$.

No começo do século $\mathrm{XX}$, dois modelos atômicos disputavam a atenção da comunidade científica. Um era o modelo de Thomson de 1903 e o outro, o modelo do japonês Hantaro Nagaoka (18665-1950) de 1904. Para Nagaoka, o átomo era formado por um caroço central positivo rodeado de anéis de elétrons girando com a mesma velocidade angular, semelhante ao planeta Saturno (por isso, ficou conhecido como modelo saturniano).

Esse impasse foi resolvido com as experiências realizadas por Rutherford, o inglês Ernest Marsden (1889-1970) e o alemão Hans Geiger (1882-1945), em 1908 sobre o espalhamento de partículas $\alpha$ pela matéria.

Rutherford e seus colaboradores, perceberam que as partículas $\alpha$, emitidas por substâncias radioativas, possuíam uma alta energia e uma massa elevada, sendo assim um bom instrumento para sondar o interior de outros átomos.

Baseado nessas evidências, Rutherford montou uma experiência com o intuito de bombardear uma fina folha de ouro com essas partículas $\alpha$. Ele percebeu, através de cintilações luminosas produzidas em uma anteparo tratado com sulfeto de zinco (ZnS) que, a maioria das partículas atravessavam a folha sem sofrer desvios e outras sofriam pequenos desvios, mas para espanto dele, pouquíssimas partículas eram desviadas em ângulos superiores a $90^{\circ}$.

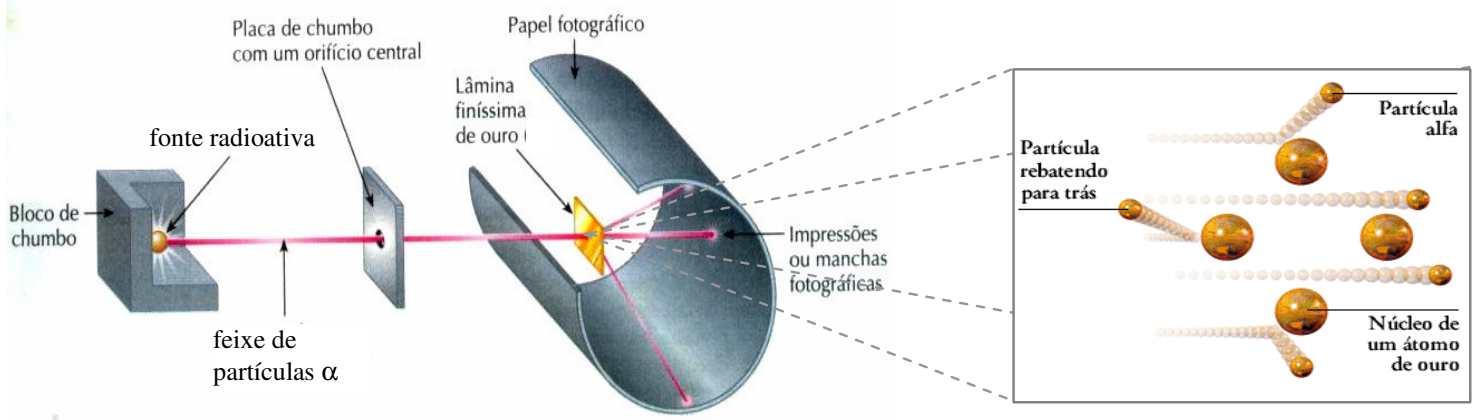

Para os pequenos desvios, o modelo de Thomson dava conta de explicar, mas como explicar os grandes desvios?

Rutherford pensou que se a carga positiva do átomo estivesse concentrada em uma única região, a força de repulsão seria muito grande para "impactos" frontais. Concluiu então, que os grandes desvios observados só poderiam resultar do encontro de uma partícula $\alpha$ com uma carga positiva concentrada em uma pequena região do átomo.

Em 1911, Rutherford propôs que o átomo se comportava como um sistema planetário em miniatura, formado de uma parte central positiva, à qual denominou núcleo, onde se concentrava praticamente toda a massa do átomo e, ao redor do núcleo, teria uma nuvem de 
elétrons girando, conhecida como eletrosfera. Com isso, o modelo atômico de Thomson foi derrubado.

Utilizando experiências parecidas com aquelas que levaram a confirmação de modelo planetário, só que agora utilizando cilindro contendo hidrogênio (gás) ao invés de uma folha de ouro, Rutherford acreditava que as partículas $\alpha$ seriam capazes de expulsar o núcleo de hidrogênio, pois possuem maior massa e são emitidas com energias elevadas. Realizando esta experiência, ele conseguiu detectar os núcleos em um anteparo fluorescente. Com isso, comprovou a existência de partículas positivas no núcleo, e propôs o nome próton (que significa primeiro, em grego) em 1920 ao núcleo de hidrogênio (núcleo mais leve).

Porém, surgiram outras questões devido a este modelo. Ao propor seu modelo, ele admitia que os elétrons giravam em torno do núcleo, porque se estivessem parados seriam atraídos eletricamente pelo núcleo. Mas ao sugerir essa saída, ele caiu em outro problema.

A eletrodinâmica clássica prevê que toda partícula carregada em movimento deve emitir energia. Desta forma, o elétron, deveria ir perdendo energia, diminuindo sua velocidade e indo em direção ao núcleo, em um movimento espiralado, como mostra a figura ao lado. Mas isso não foi "observado". Então como resolver essa questão?

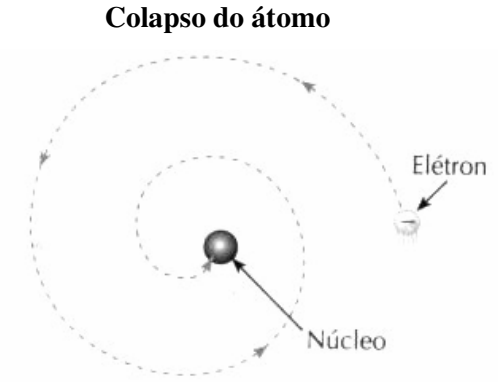

\section{O Modelo atômico de Bohr.}

Para resolver os problemas enfrentados pelo atômico de Rutherford, o físico dinamarquês Niels Bohr (1852-1962), em 1913, propôs um modelo um pouco diferente. Baseando-se na teoria quântica de Max Planck (1885-1957), Bohr sugere alguns postulados para o movimento do elétron, aperfeiçoando o modelo de Rutherford.

\section{Postulado de Bohr:}

$\checkmark$ Os elétrons se movem ao redor do núcleo em números limitados de órbitas bem definidas chamadas órbitas estacionárias;

$\checkmark$ Movendo-se nessas órbitas, os elétrons não emitem e nem absorvem energia;

$\checkmark$ Ao saltar de uma órbita estacionária para outra, o elétron absorve ou emite uma quantidade de energia bem definida, chamada de quantum de energia.

Estava assim proposto mais um novo modelo atômico, que é o modelo atual.

\section{Questões:}

1) Algumas pessoas afirmam que todas as coisas são possíveis. É possível que o núcleo de Hidrogênio emita uma partícula $\alpha$ ? Justifique sua resposta.

2) Destaque as principais diferenças entre os modelos de Rutherford e de Bohr.

3) Por que na experiência de Rutherford a maioria das partículas $\alpha$ atravessam a folha sem sofrer nenhum desvio? 


\section{A solução de um problema: a descoberta de nêutron}

A experiência de Rutherford havia mostrado que os núcleos atômicos não eram maciços e sim constituído por partes (prótons), descrevendo um novo modelo atômico. Mas ao ser determinado isso, uma questão foi levantada, ficando sem resposta. Além dos prótons, existiriam elétrons também no núcleo? Muitos pensavam que sim.

A idéia da existência de elétrons no núcleo era muito bem elaborado. Uma vez que, sabia-se que a radiação $\beta$. que tem carga negativa, ou seja, que são elétrons emitidos por núcleos radioativos.

Além disso, para que a relação carga-massa fosse correta para o núcleo, necessitaria de uma carga negativa nele. Isso porque a massa do núcleo era aproximadamente igual ao dobro de sua carga. Então para o núcleo de Nitrogênio, por exemplo, sendo sua carga (número atômico) igual a 7 , sua massa atômica deve ser 14. Essa relação já havia sido constatada e como a massa do elétron é, cerca de 2000 vezes menor do que a do próton. Desta forma, sua massa, praticamente não afetaria a massa do núcleo. Então, era razoável pensar que existissem elétrons no núcleo Sendo isso, um outro bom argumento favorável à existência de elétrons no núcleo. $\mathrm{O}$ núcleo de Nitrogênio teria então 14 prótons e 7 elétrons, com mais 7 elétrons em sua volta. Portanto no núcleo teríamos 21 partículas.

Assim, a imagem de átomo que se tinha era que existiam números iguais de elétrons e prótons, para garantir a neutralidade do átomo. Sendo que estes últimos estariam concentrados no núcleo com a metade dos números de elétrons juntos a eles que garantiria a estabilidade do núcleo. A outra metade dos elétrons, estariam em movimento em torno do núcleo, como previa Bohr.

Então era plausível pensar que no núcleo existem elétrons! Mas como essa idéia foi por água abaixo?

Outras medidas mostraram que esse modelo não era consistente. Como os prótons e elétrons têm momento angular (spin) fracionário (1/2), era de se esperar que núcleos como do Nitrogênio $(\mathrm{N})$ também tivesse esse valor semi-inteiro, mas as medidas mostravam que não. Os núcleos tinham momento angular inteiro. Ora, se o novo modelo do núcleo supunha que existiam elétrons que correspondiam a metade do número de prótons (por isso o núcleo é positivo e a massa dele é o dobro do número dos prótons), como explicar essa diferença do modelo pra as medidas?

Essas questões levaram a Rutherford a suspeitar que no núcleo não existiam elétrons mas sim, uma outra partícula que teria massa igual ao próton, mas sem carga elétrica e supunha ser um estado fortemente ligado de um próton com um elétron.

Nessa época, muitas experiências eram feitas bombardeando radiação $\alpha$ em alvos, com o intuito de investigar as reações nucleares. Em uma dessas, Walther Bothe (1891-1957) e Herbert Becker (1887-1955), dois físicos alemães, bombardearam radiação $\alpha$ sobre numa amostra de Berílio (Be) e perceberam que era produzido uma radiação com grande poder de penetração na matéria. Eles acharam que poderia se tratar de raios X mais energéticos.

Mas, Frederic Joliot Curie (1900-1958) e Irène Curie (1897-1956), observaram dois fenômenos surpreendentes. Essa radiação atravessava facilmente folhas metálicas (algo que não ocorria com os raios X) e, ao atravessar um bloco composto de Carbono e Hidrogênio (parafina), ela provocava a ejeção de prótons com uma energia razoável. Achavam que se tratava de um novo tipo de radiação.

Entretanto, eles não tiveram a inspiração para uma conclusão sobre uma nova partícula. Isso foi feito em 1932 por James Chadwick (1891-1974), um físico inglês que trabalhava com Rutherford e se interessava por questões do núcleo. 
Conhecedor das idéias de Rutherford, Chadwick percebeu que essa nova radiação constituía, ou melhor, tinha fortes indícios de ser a partícula procurada por seu colega, pois ela deveria ter carga nula, por atravessar facilmente as folhas de metais, indicando que não interagia. Também teria massa elevada e assim energia suficiente para arrancar os núcleos de hidrogênio (prótons) do bloco de parafina.

O bloco de parafina, que como se sabe é rica em Hidrogênio. Os prótons foram identificados

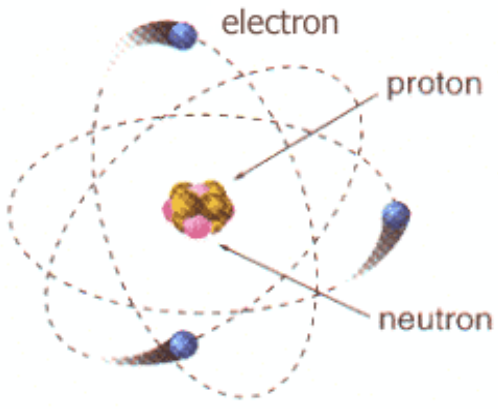
usando uma câmara de nuvens, também conhecida como câmara de Wilson. As energias dos prótons foram determinadas através dos seus alcances em diferentes gases introduzidos na câmara. Com base em massas dos átomos dos gases, já determinados anteriormente, Chadwick conclui que se, de fato, uma partícula de carga nula e massa próxima ao do próton. Estava assim descoberto o NÊUTRON, o mais novo constituinte da matéria.

Mais uma vez a física passava por uma nova revolução e a natureza era vista de outra maneira. Agora, o átomo que há menos de 40 anos era algo indivisível, passava a ser constituído por três partículas: elétron, próton e nêutron.

Assim, o Nitrogênio passou a ser constituído por 7 prótons e 7 nêutrons no núcleo, portanto 14 partículas, e com 7 elétrons girando ao redor. Como prótons e nêutrons têm spin $1 / 2$, o núcleo pode ter spin inteiro de acordo com as observações experimentais.

Também estava desvendada a constituição da radiação $\alpha$, que já se sabia ser o núcleo do átomo de He, passava a ser composto por dois prótons e dois nêutrons e, compreendendo ainda melhor a transmutação dos elementos. Porem, ainda não se sabia porque somente algumas substâncias irradiavam naturalmente.

$$
{ }^{232} \mathrm{Th} \rightarrow{ }^{228} \mathrm{Ra}+\alpha
$$

Estava resolvida mais uma questão. No entanto, algo ainda não estava soando bem. Com a descoberta do nêutron, a estabilidade do núcleo estava comprometida já que a teoria eletromagnética descreve que partículas de mesmo sinal de carga elétrica devem se repelir. Então ficava a questão no ar: como o núcleo constituído de prótons (positivos) e nêutrons (sem carga) poderiam ser estáveis? 


\section{Entendendo a estabilidade do núcleo: a força Forte}

A descoberta que o núcleo atômico era constituído de prótons e nêutrons, colocou em cheque a sua estabilidade, pois prótons repelem um ao outro por terem cargas positivas. Para contornar essa dificuldade, os físicos, o russo Dimitri Iwanenko, o alemão Werner Heisenberg (1901-1976) e o italiano Ettore Majorana (1906-1938) propuseram, independentemente, ainda em 1932, a hipótese de que os prótons e os nêutrons, como componentes do núcleo, se comportavam como partículas únicas - nucleons, que interagiam por intermédio de uma força atrativa capaz de superar a força repulsiva eletromagnética entre os prótons.

Mas, foi em 1935, que o japonês Hideki Yukawa (19071981) propôs a idéia de que a força nuclear (depois conhecida como força forte) entre os nucleons era decorrente da troca de partículas entre si. Baseado no principio da incerteza, ele previu que essa partícula teria uma massa, aproximadamente, 200 vezes maior do que o elétron (uma massa entre o próton e o

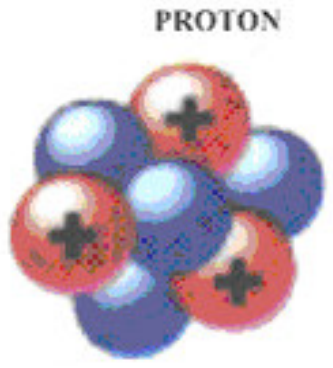

NELITRON elétron e, por esse motivo ficou conhecida inicialmente por mesótron $^{1}$ ) e, seu raio de ação seria da ordem de $\mathbf{1 0}^{-\mathbf{1 5}} \mathbf{m}(1 \mathrm{fm})$, restrigindo-se assim ao núcleo. Desta forma, explicava porque não se observava essa interação fora do núcleo.

Feito isso, Yukawa pôde determinar o tempo da interação. Sabendo que as partículas subatômicas se deslocam na velocidade próxima a da luz (c), chegou ao valor de $10^{-23} \mathrm{~s}$ para ela.

Mas, somente em 1947 que a partícula proposta por Yukawa foi detectada. Essa detecção envolveu um grupo de físicos, dentre os quais estava o brasileiro César Lattes (1924-2005). Nessa ocasião, a partícula foi denominada de méson pi ou píon $(\pi)$.

Nessa interação é importante notar que a troca desses píons faz com que um próton que emite um $\boldsymbol{\pi}^{+}$ (píon mais) transforma-se em um nêutron, e o nêutron que emite um $\pi$ (píon menos) transforma-se em próton. Os nêutrons podem trocar píons entre si, o mesmo ocorrendo entre os prótons, nesse caso a partícula tem carga nula $\pi^{0}$ (píon zero). Vemos então que temos três versões para essa nova partícula $\left(\pi^{+}, \pi^{-}, \pi^{0}\right)$.

Existe uma pequena diferença da massa dos píons que pode está relacionado com a carga, $\pi^{+}\left(140 \mathrm{Mev} / \mathrm{c}^{2}\right)$; $\pi^{-}\left(140 \mathrm{Mev} / \mathrm{c}^{2}\right)$ e $\pi^{0}\left(135 \mathrm{Mev} / \mathrm{c}^{2}\right)$.

Algo que deve ser enfatizado na interação forte é que, apesar do próton e do nêutron trocarem, em alguns casos, píons carregados, sempre será válida a conservação das cargas elétricas.

Estava assim, consolidada a interação forte!

Desta forma, com a força forte, a questão levantada na época do descobrimento da radiação $\alpha$ pode agora ser entendida.

Entretanto, essa nova troca de partículas, trouxe

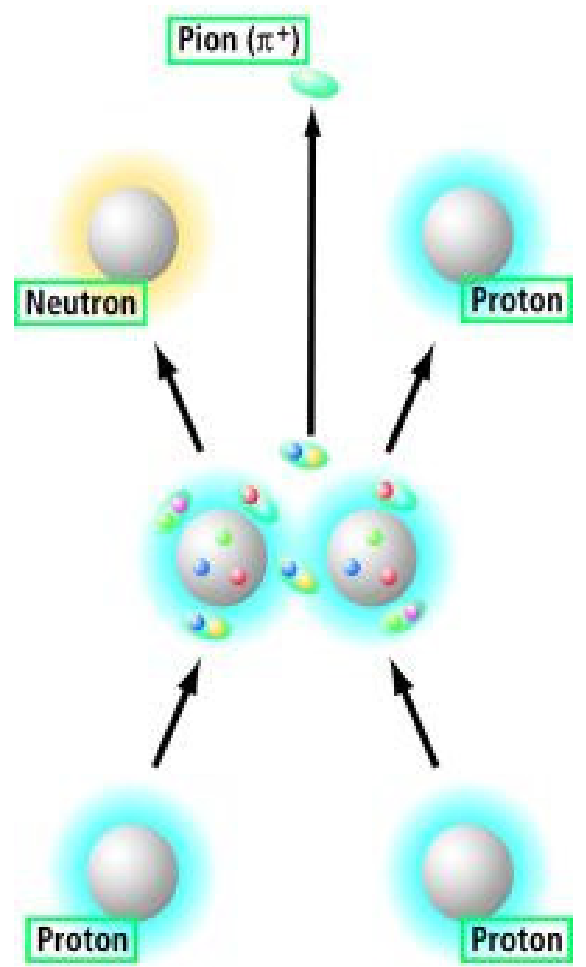
consigo duas novas questões. A primeira abalava o status de elementar do próton e do nêutron, pois como eles trocavam partículas e se modificavam, parecia que eles eram constituídos de mais de um

\footnotetext{
${ }^{1}$ do grego mesos, que significa intermediário ou médio.
} 
objeto. A segunda estava ligada a fonte dos píons. A troca de píons está ligada a qual propriedade das partículas?

\begin{tabular}{l|ccc}
\hline \multicolumn{1}{c|}{ Partícula } & $\begin{array}{c}\text { Carga } \\
\text { elétrica }(\boldsymbol{e})\end{array}$ & Spin $(\hbar)$ & $\begin{array}{c}\text { Massa de repouso } \\
\left(\mathbf{M e V / c ^ { 2 }}\right)\end{array}$ \\
\hline Píon mais $\left(\pi^{+}\right)$ & +1 & 1 & 140 \\
Píon zero $\left(\pi^{0}\right)$ & 0 & 1 & 135 \\
Píon menos $\left(\pi^{-}\right)$ & -1 & 1 & 140 \\
\hline
\end{tabular}

\section{Questões}

1) Um par de prótons de um núcleo atômico se repelem, mas também se atraem. Explique isso.

2) É razoável pensar, que em um intervalo de tempo muito pequeno existam somente prótons ou somente nêutrons dentro do núcleo? Explique sua resposta. 


\section{Entendendo a radiação $\alpha$}

Já se sabia que alguns núcleos radioativos têm a propriedade de emitirem, espontaneamente, radiação $\alpha$ e, essa radiação $\alpha$ é na verdade o núcleo ionizado do Hélio $\left(\mathrm{He}^{++}\right)$, ou seja, é constituída de dois prótons e dois nêutrons. O que ainda não se compreendia era porque alguns núcleos são radioativos e outros não.

A resposta a essa questão pôde ser proposta depois do desenvolvimento da teoria da força forte. Mas como foi isso?

Pode-se notar que os elementos que possuem número de prótons superior a $82(Z>83)$ são teoricamente instáveis em relação a radiaçãọ (decaimento $\alpha$ ).

Isso está relacionado à força forte e a força elétrica de repulsão. Quando temos núcleos com um número elevado de prótons (maior do que 83) o raio atômico cresce e a repulsão começa a superar a força forte, pois essa última, por ter um pequeno raio de atuação, começa a atuar somente entre os vizinhos mais pertos. Desta forma, o núcleo torna-se instável.

Para buscar a sua estabilidade, ele emite continuadamente, radiação $\alpha$, ou seja, ele perde prótons e nêutrons até chegar no núcleo estável, que é o caso do chumbo - $\mathrm{Pb}(\mathrm{Z}=82)$.

Contudo, para que a emissão seja efetiva, a partícula alfa precisa vencer a barreira de coulombiana criada pelo núcleo residual, o que é traduzido na linguagem quântica, por certa probabilidade de "tunelamento" através da barreira de potencial.

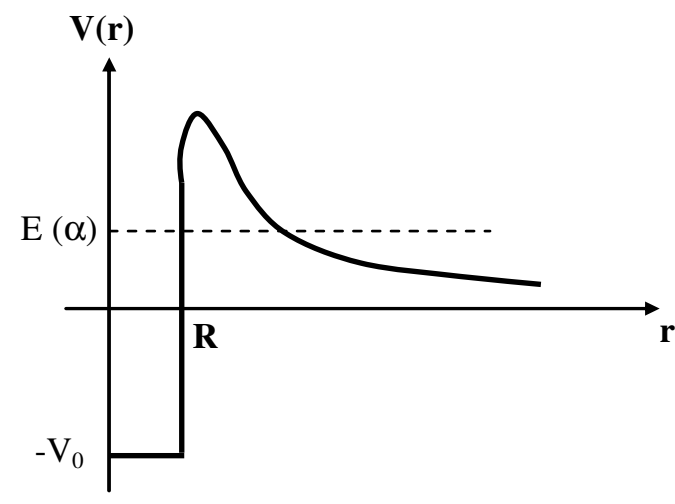

A figura mostra o potencial de um núcleo de raio $\mathrm{R}$, chamado de barreira coulombiana. Nela, vemos que a partícula alfa $(\alpha)$ não tem energia suficiente para atravessar a barreira. No entanto, graças ao efeito túnel, a alfa terá uma probabilidade de atravessar essa barreira, o que ocorrerá em determinado tempo t.

Um detalhe a ser destacado aqui é: quanto maior for a energia da partícula alfa, maior será a probabilidade dela atravessar a barreira, uma vez que a barreira se tornará mais estreita.

O quadro ao lado indica as energias de ligação de algumas partículas, para o estado ligado do elemento ${ }^{232} \mathrm{U}_{92}$. O valor negativo indica que é necessário fornecer uma quantidade de energia para essas partículas possam ser emitida pelo núcleo. Tendo uma possibilidade muito remota de atravessar a barreira de potencial, pois se encontra em uma região que a barreira de

\begin{tabular}{|c|l|}
\hline nêutron & $-7,26 \mathrm{MeV}$ \\
\hline próton & $-6,12 \mathrm{MeV}$ \\
\hline deuteron & $-10,70 \mathrm{MeV}$ \\
\hline$\alpha$ & $+5,41 \mathrm{MeV}$ \\
\hline
\end{tabular}

potencial é muito larga. Já no caso da a $\left(\mathrm{He}^{++}\right)$, essa energia é positiva, estando em uma região onde a barreira de potencial é estreita, dando a ela uma probabilidade maior de ser emitida.

Um ponto interessante, que veremos ao longo do curso é que nem sempre a soma das massas das partes é igual a massa do todo. Vejamos o exemplo do deuteron $\left({ }^{2} \mathrm{H}_{1}\right)$.

$$
\begin{gathered}
\Delta \mathrm{M}=\mathrm{m}_{\mathrm{p}}+\mathrm{m}_{\mathrm{n}}-\mathrm{M}\left({ }^{2} \mathrm{H}_{1}\right) \\
\Delta \mathrm{M}=938,272+939,533-1875,613 \\
\Delta \mathrm{M}=2,225 \mathrm{MeV}
\end{gathered}
$$


Essa diferença é devido a relação entre energia-massa $\left(E=\mathrm{mc}^{2}\right)$, parte da energia é necessária para manter o próton e o nêutron ligados. Agora se quiser separar os dois, é necessário suprir uma energia que deve ser igual a essa diferença $(2,225 \mathrm{MeV})$.

No caso do deuteron, a diferença de energia é utilizada para ligar o próton e o nêutron para formar o núcleo.

Essa diferença na massa, também fornece a idéia se o núcleo é estável ou não.

Se $\Delta \mathrm{M}>0$, o núcleo é INSTÁVEL e tem a probabilidade de decai em outro núcleo através de tunelamento.

Se $\Delta \mathrm{M}<0$, o núcleo é ESTÁVEL.

Teoricamente, essa é a explicação da instabilidade do núcleo em relação a radiação $\alpha$ através da massa. Todo núcleo original (denominado núcleo mãe) que tem massa maior do que a soma do núcleo filho e a partícula $\alpha$, emite radiação $\alpha$, com certa probabilidade, que depende da transmissão pela barreira de potencial.

Como exemplo, podemos ver o caso do Thório 232 .

$$
\left.\begin{array}{c}
\mathrm{m}_{\mathrm{Th}}=232,038051 \mathrm{u} \\
\mathrm{m}_{\mathrm{Ra}}=228,031064 \mathrm{u} \\
\mathrm{m}_{\alpha}=4,002602 \mathrm{u}
\end{array}\right\} \begin{gathered}
{ }^{232} \mathrm{Th} \rightarrow{ }^{228} \mathrm{Ra}+\alpha \\
\mathrm{m}_{\mathrm{Th}} \rightarrow \mathrm{m}_{\mathrm{Ra}}+\mathrm{m}_{\alpha} \\
232,038124 \mathrm{u}>232,033742 \mathrm{u} \\
\mathrm{u}=931,494 \mathrm{MeV}
\end{gathered}
$$

Assim, a energia de repouso do ${ }^{232}$ Th é maior do que a soma das energias do ${ }^{228} \mathrm{Ra}$ e da partícula $\alpha$, significando que o é instável, tendo uma possibilidade grande de emitir uma radiação $\alpha$. Essa diferença na massa significa que ele tem energia sobrando e que, essa energia serve para emitir espontaneamente uma $\alpha$.

\section{Questão}

1) Se o Rádio 228 emitir uma partícula $\alpha$, ele se transforma no Rádio 224. Isso é possível?

$$
m_{224}=224,020187 u
$$




\section{Aceleradores de partículas*}

Vamos analisar agora o lado experimental das coisas e discutir algum dos equipamentos utilizado em física das partículas.

A fim de atingir as altas energias necessárias em física de partículas, as experiências são realizadas num dos grandes aceleradores, embora algum trabalho seja ainda feito com radiação cósmica. Os aceleradores são muito convenientes porque fornecem feixes intensos de partículas, que podem ser rapidamente escolhidos e controlados pelo experimentador. A sua única limitação é a energia máxima da máquina. Têm sido construídos aceleradores que permitem obter partículas cujas energias já atingem ordem de $\mathrm{TeV}\left(10^{12} \mathrm{eV}\right)$.

A radiação cósmica fornece um feixe de partículas proveniente do exterior da Terra, embora este feixe tenha as desvantagens de não estar sob controle do experimentador e de ser de intensidade muito menor do que os feixes produzidos por um acelerador. Contudo, a experiência com radiação cósmica tem uma grande vantagem para certos fins: algumas das partículas da radiação cósmica tem energias muito superiores às disponíveis em qualquer acelerador.

Como o custo de um acelerador e da ordem de dezenas ou mesmo de centenas de milhões de dólares, o número de máquinas disponíveis e tanto menor, quanto maior é a energia e dimensão das mesmas. Assim, os cientistas de todas as partes do mundo agrupam-se nos Centros de energias mais elevadas para realizar as suas experiências. Basicamente, eles estão divididos em dois grupos, uns aceleram prótons e outros elétrons. Há algumas diferenças essenciais entre máquinas nos dois grupos, mas para os nossos fins a diferença importante e no que diz respeito à espécie de partículas que produzem. Os aceleradores de elétrons são geralmente usados como fontes de elétrons ou de feixes de fótons, enquanto os aceleradores de prótons são usados para produzir feixes de prótons, mésons, ou antiprótons, entre outros.

Vamos discutir um pouco o funcionamento de um acelerador de prótons. Embora os aceleradores de elétrons sejam semelhantes em princípio, muitos deles são construídos com configuração mais linear que circular. Basicamente, eles consistem num tubo longo, oco, encurvado na forma de um anel de aproximadamente $60 \mathrm{~m}$ de diâmetro. $\mathrm{O}$ feixe de prótons percorre o tubo, mantido numa órbita circular por um campo magnético fornecido por oito grandes ímãs colocados ao longo da circunferência do anel. Em cada volta, os prótons passam através de três cavidades aceleradoras com uma queda de tensão de 20000 volts em cada, de modo que um próton ganha uma energia de 60.000 elétron-volt em cada volta no anel. É claro que à medida que a velocidade do próton aumenta, o campo magnético é também aumentado a fim de manter o feixe no mesmo círculo.

Os prótons são obtidos ionizando hidrogênio numa descarga elétrica, muito mais que numa lâmpada de néon. Então são acelerados a $50 \mathrm{MeV}$ num acelerador linear (linac), que consiste em 124 aceleradores eletrostáticos em linha. Em cada 4 segundos um ímã é pulsado a fim de guiar um feixe de prótons desde a extremidade do linac através de uma janela de metal fina, para o anel principal, onde permanecem durante cerca de 200.000 (duzentas mil) revoluções, até atingirem a energia completa. Isto leva cerca de 0,2 segundos, durante os quais percorrem $56000 \mathrm{Km}$ - maior que a distância à volta do Mundo! Nesta altura há cerca de $10^{12}$ prótons, cada um com a energia de $12,5 \mathrm{GeV}$, no feixe que circula no interior do acelerador. 


\section{César Lattes e o méson pi}

Uma das partículas que interagem entre prótons e nêutrons no interior do núcleo atômico chama-se méson $\pi$ ou píon. Ela foi proposta teoricamente pelo físico japonês $\mathrm{H}$. Yukawa em 1937 sendo detectada somente em 1947, ou seja, dez anos após sua especulação. O físico brasileiro Cesar Lattes foi um dos principais envolvidos na detecção dessa partícula. Tal fato foi um dos motivos que proporcionou um grande e rápido desenvolvimento para a Física e para as Ciências no Brasil na época.

Dentre seus trabalhos realizados, dois se destacaram tanto pela importância para a Física de Partículas da época quanto pela repercussão: a participação na descoberta do píons através dos raios cósmicos, em colaboração com G. Occhialini e C.F. Powell (ganhador do prêmio Nobel em 1950) na Universidade de Bristol, Inglaterra e em 1948, na detecção do méson pi utilizando um acelerador de partícula construído em Berkeley, Estados Unidos.

Antes de passarmos diretamente para os trabalhos realizados por Lattes, vamos buscar entender um pouco o método que ele trabalhava.

\section{As emulsões nucleares nos raios cósmicos}

A emulsão fotográfica comum é um instrumento de registro contínuo, podendo guardar nas imagens latentes (antes de serem reveladas), todos os eventos que a sensibilizaram a partir do momento em que é exposta à radiação cósmica. O problema é de tornar um filme fotográfico comum sensível à trajetória de uma partícula ionizante. Para isso, é necessário aumentar a quantidade de sais de prata no filme a ser revelado. É a precipitação da prata metálica induzida pela luz que torna visível a imagem dos objetos fotografados. Esse problema foi sendo progressivamente resolvido até que em 1946 os físicos já dispunham de um novo instrumento sensível aos traços de partículas carregadas: as emulsões nucleares (basicamente consiste em um filme fotográfico acrescido de sais de prata).

\section{A descoberta em Bristol}

Lattes foi levado a Bristol por Occhialini com quem já havia colaborado na USP construindo câmaras de detecção de partículas. Occhialini trabalhava com Powell (Nobel em 1950 pela descoberta do méson pi) em Bristol. O laboratório estava recrutando alunos mas devido ao incentivo do governo inglês no esforço de guerra, os jovens cientistas ingleses não se interessaram em participar de trabalhos dessa natureza. Assim, Occhialini sugeriu a C. Powell que recrutasse o brasileiro.

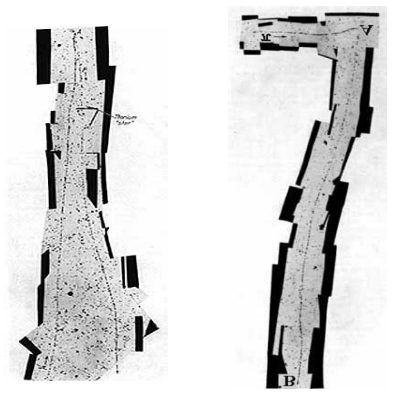

A "sacada" de C. Lattes foi exatamente em identificar esse composto (tetraborato de sódio - bórax) que, misturado às emulsões, tornavam capazes de alongar em muito tempo a retenção das imagens. Isso viabilizava as exposições de longa duração necessárias para a detecção de partículas nos raios cósmicos. Após exposição frustrada das chapas nos Pirineus, a 2.800m de altitude, por Occhialini, Lattes expôs as chapas no Monte Chacaltaya nos Andes Bolivianos $(5500 \mathrm{~m}$ de altitude por ter menos ar na atmosfera) possibilitando detectar nos rastros deixados nas emulsões o méson pi. A radiação cósmica consiste basicamente de fragmentos microscópicos de corpos celestes (sol, explosões de estrelas, etc) eletricamente carregados que possuem alta 
energia. Como conseqüência, surge íons de diversos átomos que penetram na atmosfera terrestre.

\section{A descoberta em Berkeley}

Os trabalhos feitos em Bristol com raios cósmicos não mostraram conclusivamente que o méson $\pi$ fosse uma partícula nuclearmente ativa. A demonstração experimental, que essa partícula não tinha forte interação com a matéria nuclear, foi observada quando E. Gardner e C. Lattes aceleraram partículas alfa de $380 \mathrm{Mev}$ através de um sincrociclotron da Universidade da Califórnia em 1948. Foi usado um alvo de carbono e as partículas alfa de $380 \mathrm{MeV}$ ao incidirem sobre os prótons e nêutrons do átomo de carbono, produziram os mésons $\pi$, registrando sua trajetória em emulsões nucleares colocadas no interior do equipamento. Por mais de um ano, os físicos de Berkeley não haviam conseguido detectar os mésons por desconhecimento do método apropriado de utilização das emulsões nucleares e porque procuravam uma partícula mais leve que os mésons. Os mésons não existem normalmente no interior dos núcleos, eles são criados e emitidos durante colisões de projéteis externos com prótons e nêutrons dos núcleos. No momento de sua descoberta foram tidos como os únicos agentes das forças nucleares.

Dessa forma C. Lattes e o méson pi foram considerado pela opinião pública brasileira como um símbolo de esperanças coletivas, uma vez que a Física em meados do século passado estava associada à idéia de progresso e se traduzia, nos países atrasados, como aliada na luta contra o subdesenvolvimento.

\section{Questões:}

1) De acordo com o texto, qual foi o principal papel do brasileiro César Lattes na detecção dos mésons? O que você acha que tal descoberta representou para a Ciência e para a Física brasileira da época?

2) Você já tinha ouvido falar em algum trabalho de um físico brasileiro? Em caso positivo, qual?

3) Acha que seria interessante trabalhar alguns dos conteúdos de Física Moderna e Contemporânea no ensino médio sob a perspectiva de trabalhos realizados com a participação de cientistas brasileiros? Por que? Justifique.

4) Você provavelmente nunca tinha ouvido falar em algum trabalho de um físico brasileiro, principalmente pelos livros. Por que acha que isso acontece? Justifique sua resposta!

5) Para você Ciência ou Física interessante e "legal" é aquela divulgada na mídia e geralmente feita por países ricos ou também gostaria de saber mais respeito da Ciência desenvolvida no Brasil? Ainda que não seja considerada de ponta e tão divulgada!

6) Sincera e honestamente, você acha importante conhecer a História da Ciência desenvolvida com participação do Brasil? Por que? O que isso poderia te acrescentar na sua formação como professor? Justifique suas respostas! 


\section{Os constituintes do nucleons: o modelo de quarks}

A proposta, na década de 30, da força forte entre os nucleons (prótons e nêutrons) por Yukawa foi confirmado na década de 40 , pela detecção do píon $(\pi)$, a partícula mediadora dessa nova força, por um grupo de pesquisadores no qual o brasileiro César Lattes fazia parte. Assim o caráter elementar do próton e do nêutron começou a ser colocado em dúvida.

Mas não era somente está questão que abalava a estrutura elementar do próton e do nêutron. Com o desenvolvimento dos aceleradores, novas partículas com propriedades bem parecidas com as do próton e nêutron, foram sendo produzidas.

Partículas como o sigma mais $\left(\Sigma^{+}\right)$, que tem a mesma carga e spin do próton, porém mais pesado $\left(1189 \mathrm{Mev} / \mathrm{c}^{2}\right)$; lambda zero $\left(\Lambda^{0}\right)$ com carga nula e spin $1 / 2$, igual ao nêutron, no entanto, com mais massa $\left(1116 \mathrm{Mev} / \mathrm{c}^{2}\right)$ e a partícula káon zero $\left(\mathrm{k}^{0}\right)$ que possui as mesmas propriedades do píon, mas com massa bem maior $\left(498 \mathrm{Mev} / \mathrm{c}^{2}\right)$. Além dessas, outras partículas foram produzidas e,

\begin{tabular}{c|ccc}
\hline Particula & $\begin{array}{c}\text { Carga } \\
\text { elétrica }\end{array}$ & Spin & $\begin{array}{c}\text { Massa } \\
\text { MeV/c }^{2}\end{array}$ \\
\hline Sigma mais $(\Sigma+)$ & +1 & $3 / 2$ & 1189 \\
Delta mais $\left(\Delta^{+}\right)$ & +1 & $3 / 2$ & 1235 \\
Lambda zero $\left(\Lambda^{0}\right)$ & 0 & $1 / 2$ & 1116 \\
Delta dois mais $\left(\Delta^{++}\right)$ & +2 & $3 / 2$ & 1233 \\
Káon zero $\left(\mathrm{k}^{0}\right)$ & 0 & 1 & 498 \\
\hline
\end{tabular}
"misteriosamente" apresentavam praticamente as mesmas propriedades. Essas evidências levaram os cientistas a suspeitarem de se tratar de partículas pertencentes a uma mesma família. Essa família recebeu o nome de hádrons (que significa, em grego, "forte", "robusto") que seriam as partículas que interagem por meio da força forte.

Com isso, reforçava-se a dúvida sobre o caráter elementar dessas partículas. Os cientistas suspeitaram que a natureza poderia ser descrita por uma forma mais simples e não através de uma enorme quantidade de partículas. Então veio a questão: será que os hádrons não possuem uma estrutura interna?

Para responder essa questão, o norte-americano Murray Gell-Mann (1929- ) e George Zweig (1937- ) propuseram que essas partículas (hádrons) seriam constituídas de partículas ainda menores, que foram designadas de quarks (nome dado por Gell-Mann). Assim, partículas como o próton e o nêutron seriam formandos por três quarks, recebendo o nome de bárions (em grego, significa "pesado") e as partículas como os píons e o káon seriam formados por dois quarks(quark - antiquark), recebendo o nome de mesóns.

Esses quarks se apresentariam em três versões (depois chamados de sabores) up $(u)$; down $(d)$ e strange $(s)$. Teriam spin fracionário $(1 / 2)$ como os próprios bárions e sua carga, seria frações da carga do elétron $(1 / 3,2 / 3)$. Desta forma, o próton, por exemplo, seria formado por dois quarks up e um down $(\mathrm{u}, \mathrm{u}, \mathrm{d})$ e o nêutron, por dois down e um up (u,d,d).

Mais tarde, algumas evidências (que discutiremos depois) levaram os físicos a suspeitarem da existência de mais três tipos de quarks, que foram o charm $(c)$ detectado em 1974; o bottom (b) detectado no final da década de 70 e por último o top $(t)$ detectado em 1995.

Assim, ficaria completa a estrutura do modelo dos quarks com seus seis sabores: up; down; strange; charm; bottom e top.

Mas algo não estava muito bem com essa proposta. Já que eram partículas de spin fracionário (1/2), deveriam obedecer ao principio da exclusão de Pauli que diz que "duas partículas iguais, não podem ocupar o mesmo estado quântico, ou seja, três quarks do mesmo sabor não poderiam existir numa mesma partícula. Porém, tinha uma partícula com essa característica, o delta dois mais $-\Delta^{++}(\mathrm{u}, \mathrm{u}, \mathrm{u})$, violando esse princípio. Então o que estaria errado?
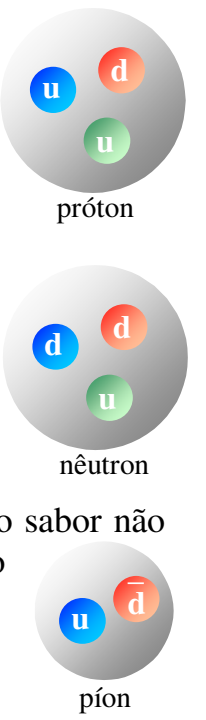


\section{A carga cor}

Para solucionar esse empasse, em 1964 o físico norte-americano Oscar W. Greenberg, sugeriu que cada "sabor" dos quarks poderia existir em três estados diferentes, que ele chamou de vermelho $(v m)$, verde $(v d)$ e azul ( $a z)$. Essas seriam as "cargas cores" do quarks, algo parecido com a carga elétrica, só que em 3 tipos distintos. Aqui a palavra cor não tem nada haver com o termo empregado habitualmente, ou seja, não são as cores do espectro de luz visível.

Assim, nessa proposta, os quarks só poderiam se agrupar de tal forma que os hádrons formados, fossem incolor. Desta forma, os bárions seriam formados por um quark de cada cor, de tal maneira que o resultado final fosse branco. Já os mesóns, seriam formados por dois quarks, um de uma cor e o outro, com a cor complementar (anticor), que somadas dariam branco. Por esse motivo, não se observaria nenhum efeito das cores fora dos hádrons.

Mas de que maneira um quark atrairia o outro, formando essas partículas?

Junto com a teoria da carga cor, estava previsto também a maneira como os quarks deveriam interagir. Assim como as cargas elétricas se atraem quando são diferentes e se repelem quando são iguais; aconteceria o mesmo com a cor. Quarks de mesma cor se repelem e, de cores diferentes se atraem. Essa atração ocorreria também entre a cor e sua complementar (anticor).

Essa interação entre as cores seria dada por uma nova partícula: os glúons, que seriam uma espécie de cola ou mola entre os quarks, prendendo-os. A medida que um quark fosse se afastando do outro sua intensidade aumentaria, sendo difícil retirar um quark dessa formação. Desta forma, os glúons seriam os mediadores da força forte entre os quarks, devido à carga cor. O papel dessa partícula na interação forte é fazer a troca de cores entre os quarks, mantendo-os unidos. Quando um quark vermelho $\left(\mathrm{q}_{\mathrm{vm}}\right)$ emitisse um glúon vermelho antiazul se tornaria azul $\left(\mathrm{q}_{\mathrm{az}}\right)$. É dessa forma que os quarks interagem entre si, emitindo glúons e trocando de cores.

A teoria previa também, que essa nova partícula: os

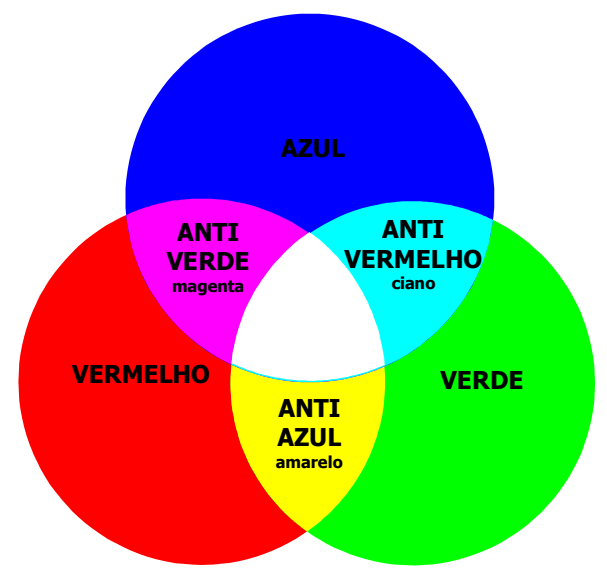
glúons, não teriam carga elétrica e nem massa de repouso, tendo spin inteiro (1) e sendo bicolores (cor $+\operatorname{anticor}^{1}$ ), não podendo ser branco, ou seja, cor+anticor complementares. Então, seriam no total de oito glúons.

Depois disso tudo, como ficava a interação entre os nucleons através dos píons?

Com o modelo dos quarks, a interação entre os nucleons passou a ser vista como uma manifestação secundária das forças entre os quarks (força forte residual). Mas como isso ocorre?

Quando uma grande quantidade de energia é fornecida a um sistema de quarks, um par de quarks é criado, dando origem aos píons de Yukawa.

Apesar dos físicos acreditarem que o quark é real, ainda não se conseguiu detecta-lo isoladamente, ou seja, só temos quarks enquanto constituintes dos hádrons.

As evidências que fizeram os físicos acreditarem na existência do quark está baseada nas experiências com espalhamento de partículas. Aquelas mesmas experiências utilizadas por Rutherford para "encontrar" o núcleo. Só que aqui, temos os prótons sendo bombardeados com elétrons que os atravessam, sofrendo pequenas deflexões ao interagir com os quarks ou são ricocheteados ao colidir com eles no interior dos prótons.

\footnotetext{
${ }^{1}$ As anticores são: antiazul (az) - amarelo; antivermelho (vm) - ciano; antiverde (vd) - magenta
} 


\section{Questões:}

1) Os glúons são partículas mediadoras da força forte e atuam em partículas que têm carga cor. Sabendo disso, seria possível os glúons interagirem entre si? Justifique.

2) Sabendo-se que para um quark mudar sua cor, ele tem que emitir um glúon. Qual é a cor e a anticor do glúon emitido para um quark azul se tornar verde? 


\section{A descoberta do neutrino: uma nova interação}

Na década de 20, desenvolveu-se uma questão polêmica relacionada a radiação $\beta$. Apesar de se conhecer que era uma emissão de um elétron pelo núcleo, permanecia a questão: se um elétron é emitido por um núcleo A que se transforma em um núcleo $\mathrm{B}$ e tem energia menor do que suas massas de repouso, para onde vai a energia que está faltando?

$$
\mathrm{A} \rightarrow \mathrm{B}+\mathrm{e}^{-}
$$

Esperava-se que a energia do elétron fosse igual à diferença de energia dos núcleos $\mathrm{A} \mathrm{e}$ B. Sendo assim, teria um valor bem determinado, mas isso não acontecia. A energia do elétron variava de zero até essa diferença. O que trazia um grande problema para a física.

Outro problema estava relacionado com a conservação do momento angular (spin) no decaimento do nêutron: $\mathrm{n} \rightarrow \mathrm{p}+\mathrm{e}^{-}$. Como as três partículas têm spin $1 / 2$, havia uma violação da conservação do momento angular que não se conseguia explicar.

Em 1923, Bohr passou a propor que o princípio da conservação de energia só seria válido para fenômenos macroscópicos. Mas em 1930, Wolfgang Pauli (1900-1950) resolveu a controvérsia postulando a existência de uma partícula neutra, de massa muito pequena, (cálculos recentes, mostram um limite máximo para a massa dessa partícula é $16 \mathrm{ev} / \mathrm{c}^{2}$ ) e que é emitida junto com o elétron pelo núcleo radioativo e, por ser neutro e muito pequeno não era detectada. Tratava-se então de um decaimento em três partículas $\left(n \rightarrow p+e^{-}+v\right)$ e, não duas $\left(\mathrm{n} \rightarrow \mathrm{p}+\mathrm{e}^{-}\right.$) como se imaginava ser. Essa nova partícula recebeu o nome de Enrico Fermi (1901-1954), em 1934 de neutrino ( $v$ ) que significa pequeno neutro em italiano, quando formulou também a teoria de uma nova interação, que seria responsável pelo decaimento $\beta$, ou seja:

$$
\mathrm{A} \rightarrow \mathrm{B}+\mathrm{e}^{-}+\mathrm{v}
$$
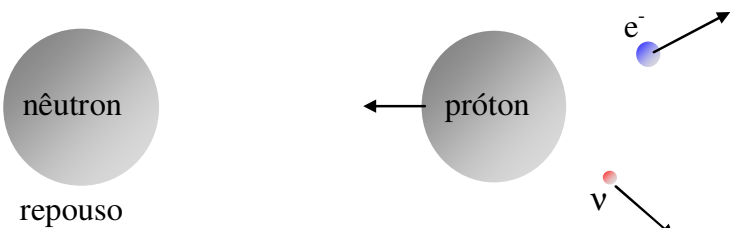

Analisando melhor o decaimento $\beta$, Fermi concluiu que uma nova forma de interação estaria em jogo. Notava-se que os núcleos que decaiam com emissão $\beta$ tinham caracteristicamente um tempo de vida longo, podendo significar que a interação responsável por esse decaimento tivesse uma intensidade muito pequena, sendo necessário esperar um tempo muito longo para que o efeito provocasse a desintegração. Por esse motivo, passou a ser designado por Fermi de força fraca.

Como a intensidade dessa força é muito pequena, a interação do neutrino com a matéria, se tornava muito pequena. Além do mais, ele não era sensível a força eletromagnética, por ser neutro. Por isso tornava-se muito difícil sua detecção.

Essa partícula só foi detectada em 1953 pelos físicos norte-americanos Frederick Reines (1918- ) e Clyde Lowain Cowan (1919- ), quando estudaram a colisão de um fluxo de neutrinos, provenientes de um reator nuclear, com prótons de um cintilador líquido. Cintiladores líquidos são usados para detectar nêutron, obtendo o espectro de energia do próton de recuo. Essa detecção só foi possível, utilizando a conservação de momento linear. 


\section{A força fraca}

Com a descoberta do neutrino, presente na emissão $\beta$ e, devido ao "longo" tempo de meia vida desse decaimento, houve a necessidade de propor um novo tipo de interação que explicasse essas evidências, que foi chamada de força fraca.

A força fraca atua nas partículas, transformando-as em outras, emitindo necessariamente um neutrino, ou seja, em qualquer decaimento de partícula que tiver o neutrino envolvido, ele se dará via força fraca.

Desta forma, no decaimento do tipo ${ }^{198} \mathrm{Au} \rightarrow{ }^{198} \mathrm{Hg}+\mathrm{e}^{-}+\mathrm{v}$. O elétron não existe dentro do núcleo (como já vimos), ele é criado durante o processo de decaimento, pela conservação da massa em energia. Assim, o núcleo permanece com o mesmo número de partículas (198), porém com uma carga positiva a mais.

Mas como isso ocorre?

Quando o núcleo de ouro $\left({ }^{198} \mathrm{Au}\right)$ decai no mercúrio $\left({ }^{198} \mathrm{Hg}\right)$, o decaimento ocorre apenas em uma partícula dele, isto é, um nêutron decai em um próton. Nesse caso, um quark down do nêutron se transforma em um quark up, emitindo uma partícula $\boldsymbol{W}$, que decai em seguida em um elétron e um neutrino. Esse é o mecanismo da força fraca.

$$
\underset{\text { udd }}{\mathbf{n}} \rightarrow \underset{\text { uud }}{\mathbf{p}}+\mathbf{e}^{-}+\mathbf{v}
$$

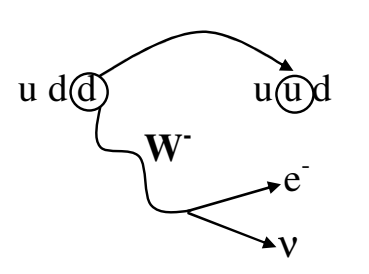

A partícula $\boldsymbol{W}\left(81 \mathrm{Gev} / \mathrm{c}^{2}\right)$, assim como a $\boldsymbol{W}^{-}(81$ $\left.\mathrm{Gev} / \mathrm{c}^{2}\right)$ e $\boldsymbol{Z}^{\boldsymbol{0}}\left(91 \mathrm{Gev} / \mathrm{c}^{2}\right)$, são partículas mediadoras da força fraca e foram descobertas em 1983. Devido a suas massas serem grandes, tornam o raio de atuação muito pequeno, da ordem de $10^{-17} \mathrm{~m}(0,01 \mathrm{fm})$, demonstrando que essa força age sorrateiramente no interior das partículas, transfomando-as em outras.

Assim como a carga cor é a fonte da força forte, aqui temos a carga fraca (denominação que aparece algumas vezes) como fonte da força fraca.

\section{Questão:}

Através do processo da força fraca, esquema acima, tente explicar a reação:

$$
\begin{gathered}
\Lambda^{0} \rightarrow \pi^{-}+p \\
\text { (uds) (ud) (uud) }
\end{gathered}
$$




\section{Partículas estranhas: as novas leis de conservação}

Com o desenvolvimento cada vez maior dos aceleradores, centenas de partículas foram sendo criadas. Verificava-se que muitas delas tinham tempo de vida muito curto, conseqüentemente, decaindo em outras partículas, formando cada vez mais partículas.

Para entender melhor porque algumas partículas tinham o seu decaimento bem determinado, ou seja, decaiam em algumas partículas e não em outras, os físicos tiveram que "criar" novas leis de conservação além das que já eram conhecidas:

- Princípio da conservação de massa (obedecendo a relação massa-energia);

- Princípio da conservação do momento (angular e linear);

- Princípio da conservação da carga elétrica.

Esses três princípios já eram bem claros, pois em nenhum momento deixaram de ser válidos, não sendo violado por nenhuma interação ou decaimento.

Os novos princípios eram baseados em características de certo grupo de partículas, que tinham nomes específicos.

\section{Número bariônico}

O primeiro novo princípio, diz respeito aos bárions (partículas formadas por 3 quarks), sendo denominada de número bariônico $(B)$. Foi atribuído a todos os bárions o valor +1 e aos antibarions, o valor $\mathbf{- 1}$. Todas as outras partículas têm valor nulo.

Para que o número bariônico seja conservado, o seu valor tem que ser igual antes e depois do decaimento (reação).

Exemplo: $\boldsymbol{\pi}^{-}+\mathbf{p} \rightarrow \mathbf{k}^{+}+\boldsymbol{\Sigma}^{-}$

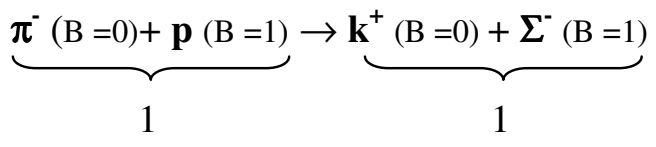

Nessa reação o número bariônico é conservado, logo a reação pode ocorre.

Tomada juntamente com a conservação de energia, a conservação do número bariônica exige que o bárion mais leve, o próton, seja estável. Atualmente, isso está sendo discutido se é verdade.

\begin{tabular}{l|c}
\hline \multicolumn{1}{c|}{ Bárion } & $\boldsymbol{n}^{\boldsymbol{o}}$ bariônico $(\boldsymbol{B})$ \\
\hline Próton $(\mathrm{p})$ & +1 \\
Neutron $(\mathrm{n})$ & +1 \\
Lambda zero $\left(\Lambda^{0}\right)$ & +1 \\
Sigma mais $\left(\Sigma^{+}\right)$ & +1 \\
Sigma zero $\left(\Sigma^{0}\right)$ & +1 \\
Sigma menos $\left(\Sigma^{-}\right)$ & +1 \\
\hline \multicolumn{1}{c|}{ Antibárion } & $\boldsymbol{n}^{\boldsymbol{o}}$ bariônico $(\boldsymbol{B})$ \\
\hline antipróton $(\mathrm{p})$ & -1 \\
antineutron $(\mathrm{n})$ & -1 \\
\hline
\end{tabular}

\begin{tabular}{l|ccc}
\hline \multicolumn{1}{c|}{ Lépton } & $\boldsymbol{L}_{\boldsymbol{e}}$ & $\boldsymbol{L}_{\boldsymbol{\mu}}$ & $\boldsymbol{L}_{\boldsymbol{\tau}}$ \\
\hline elétron $\left(\mathrm{e}^{-}\right)$ & +1 & 0 & 0 \\
neutrino do elétron & +1 & 0 & 0 \\
$\left(v_{\mathrm{e}}\right)$ & 0 & +1 & 0 \\
múon $\left(\mu^{-}\right)$ & 0 & +1 & 0 \\
neutrino do múon $\left(v_{\mu}\right)$ & 0 & 0 & +1 \\
$\operatorname{tau}\left(\tau^{-}\right)$ & 0 & 0 & +1 \\
neutrino do tau $\left(v_{\tau}\right)$ & 0 &
\end{tabular}

\section{Número leptônico}

A segunda lei de conservação está ligada a partículas parecidas com o elétron que são o múon - $\mu$ $\left(107 \mathrm{Mev} / \mathrm{c}^{2}\right)$ e o tau $-\boldsymbol{\tau}\left(1777 \mathrm{Mev} / \mathrm{c}^{2}\right)$. Eles têm as mesmas características do elétron, porém massas bem maiores. Cada partícula dessas, tem um neutrino associado: e $-v_{\mathrm{e}} ; \mu-v_{\mu} ; \tau-v_{\tau}$. Essas seis partículas são chamadas, genericamente, de léptons. 
Aplicado a essas partículas temos o número leptônico, que deve ser conservado em todas as reações. Aqui, são atribuídos o valor $+\mathbf{1}$ para o número leptônico $\left(\mathrm{L}_{\mathrm{e}}\right)$ ao elétron e seu neutrino e, -1 para suas antipartículas. As demais partículas são nulas, incluindo todos os outros léptons.

Essa atribuição de valor é análoga para o número leptonico do múon $\left(\mathrm{L}_{\mu}\right)$ e do tau $\left(\mathrm{L}_{\tau}\right)$.

$$
\begin{aligned}
& \text { Exemplo: } \mathbf{n} \rightarrow \mathbf{p}+\mathbf{e}^{-}+\mathbf{v}_{\mathbf{e}} \\
& \mathbf{n}(\mathrm{B}=1) \rightarrow \mathbf{p}(\mathrm{B}=1)+\mathbf{e}^{-}(\mathrm{B}=0)+\mathbf{v}_{\mathbf{e}}(\mathrm{B}=0) \\
& \underbrace{\mathrm{n}(\mathrm{B}=1)}_{1} \rightarrow \underbrace{\mathrm{p}(\mathrm{B}=1)+\mathrm{e}^{-}(\mathrm{B}=0)+\mathrm{v}_{\mathrm{c}}(\mathrm{B}=0)}_{1} \\
& \underbrace{\mathbf{n}\left(\mathrm{L}_{\mathrm{e}}=0\right)}_{0} \rightarrow \underbrace{\mathbf{p}\left(\mathrm{L}_{\mathrm{e}}=0\right)+\mathbf{e}^{-}\left(\mathrm{L}_{\mathrm{e}}=1\right)+\mathbf{V}_{\mathbf{e}}\left(\mathrm{L}_{\mathrm{e}}=-1\right)}_{0} \\
& \Rightarrow \text { Logo, pode ocorrer. } \\
& \begin{array}{l}
\mu^{-} \rightarrow \mathbf{e}^{-}+v_{\mathbf{e}} \\
\underbrace{\mu^{-}\left(L_{\mu}=1\right)}_{1} \rightarrow \underbrace{\mathbf{e}^{-}\left(L_{\mu}=0\right)+v_{\mathbf{e}}\left(L_{\mu}=0\right)}_{0}
\end{array} \\
& \underbrace{\mu^{-}\left(L_{\mathrm{e}}=0\right)}_{0} \rightarrow \underbrace{\mathbf{e}^{-}\left(L_{\mathrm{e}}=1\right)+\boldsymbol{V}_{\mathrm{e}}\left(L_{\mathrm{e}}=1\right)}_{2} \quad \Rightarrow \text { Logo, não pode ocorrer }
\end{aligned}
$$

\section{Estranheza}

Em algumas reações, podei-se observar o comportamento um tanto estranho de alguns hádrons pesados, como na seguinte reação:

$$
\begin{gathered}
\pi^{-}+\mathbf{p}^{+} \rightarrow \mathbf{k}^{0}+\Lambda^{0}(\mathrm{i}) \\
\text { porém: } \Lambda^{0} \rightarrow \pi^{-}+\mathbf{p}^{+}(\mathrm{ii})
\end{gathered}
$$

Ambas as reações envolvem hádrons, por isso devem reagir via força forte, com um tempo de $10^{-23} \mathrm{~s}$. Porém, a partícula $\mathrm{k}^{0}$ (káon zero) e $\Lambda^{0}$ (lambda zero) decaem em um tempo relativamente lento $\left(10^{-8} \mathrm{~s}\right)$, característico da interação fraca. Observou-se também que essas partículas pareciam aos pares.

O comportamento antagônico dessas partículas levou Gell-Mann e Kazuhiko Nishijima a proporem,

\begin{tabular}{l|c}
\hline \multicolumn{1}{c|}{ Partículas } & Estranheza $(\mathbf{S})$ \\
\hline Próton $(\mathrm{p})$ & 0 \\
Neutron $(\mathrm{n})$ & 0 \\
Lambda zero $\left(\Lambda^{0}\right)$ & -1 \\
Sigma mais $\left(\Sigma^{+}\right)$ & -1 \\
Sigma zero $\left(\Sigma^{0}\right)$ & -1 \\
Sigma menos $\left(\Sigma^{-}\right)$ & -1 \\
Píon mais $\left(\pi^{+}\right)$ & 0 \\
Píon menos $\left(\pi^{-}\right)$ & 0 \\
Píon zero $\left(\pi^{0}\right)$ & 0 \\
Káon mais $\left(\mathrm{k}^{+}\right)$ & +1 \\
Káon zero $\left(\mathrm{k}^{0}\right)$ & +1 \\
Káon menos $\left(\mathrm{k}^{-}\right)$ & -1
\end{tabular}
independentemente, uma nova propriedade que só seria conservada nas reações provenientes das interações forte e eletromagnética. Nas reações via interação fraca ela poderia ser violada, como mostra a segunda reação.

Essa propriedade recebeu o original nome de estranheza $(S)$. Foi atribuída estranheza +1 para as partículas $\mathrm{k}^{+}$e $\mathrm{k}^{0}$ e estranheza $\mathbf{- 1}$ para partículas $\Lambda^{0}, \Sigma^{+}, \Sigma^{-}$e $\Sigma^{0}$ e nulo para os nucleons e o píon.

A estranheza de outras partículas poderia ser calculada através de análise das reações e dos decaimentos que participavam. 


\section{As antipartículas: a descoberta do pósitron}

Imagine você andando na rua, de repente, olha para o outro lado e vê, na outra calçada, uma pessoa que só não é idêntica a você, por um detalhe (uma pinta, um piercing, o cabelo partido ou uma outra característica que está invertida). Acho que você, como todos, ficaria espantado e muito assustado, perguntando como é possível isso acontecer? Mas para nossa tranqüilidade, sabemos que isso é praticamente impossível de ocorrer.
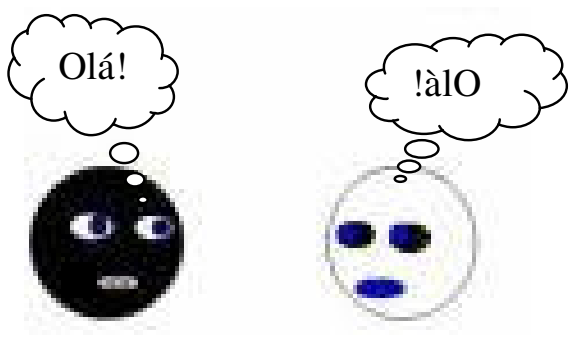
Porém, no caso das partículas elementares, não!

A idéia de partículas quase idênticas (opostas somente em uma propriedade) começou a ser formulada em 1928, o inglês Paul Dirac, elaborou uma expressão relativística para a função de onda do elétron. Nessa expressão, a energia do elétron é dada por:

$$
E^{2}=\left(m_{0} c^{2}\right)^{2}+(p c)^{2} \Rightarrow E= \pm \sqrt{\left(m_{0} c^{2}\right)^{2}+(p c)^{2}}
$$

Dirac notou que a equação admitia duas soluções, uma com energia positiva e a outra, "misteriosamente" com energia negativa, que não seria descartada. Porém, ao não descartar essa parte da solução, ele se confrontou com uma questão.

Mas, se há estados de energia negativo, dada à tendência dos sistemas físicos evoluírem para o estado de energia mínima, o elétron deveria ir para estados mais negativos, irradiando infinitamente energia e isso não acontece.

Para solucionar esse problema, Dirac propôs o conceito de "mar de elétron" (este "mar infinito de elétrons" seria uniforme e por isso não produziria efeitos observáveis), postulando que todos os estados negativos de energia já estariam ocupados por elétrons e, devido ao princípio da exclusão de Pauli, os elétrons dos estados positivos não poderiam transitar para os estados negativos já ocupados.

Desta forma, somente seriam observados efeitos, quando um elétron, que ocupa um dos estados negativos, for excitado transitando para um estado positivo, deixando um buraco (ou bolha) no mar, que então, poderia ser observado. Esse buraco se comportaria como uma partícula de carga positiva e energia positiva.

O processo de excitação do elétron do estado negativo, pode ser descrito da seguinte maneira: um fóton $(\gamma)$ atinge um elétron de energia negativa e promove a um estado de energia positiva, deixando um buraco no mar, com falta de carga negativa. Tornando o buraco uma partícula positiva.

O candidato mais óbvio para ocupar esse lugar seria o próton. No entanto, a equação, previa que essa partícula deveria ter a mesma massa do elétron.

A inexistência de uma partícula com essas características colocava em dúvida toda a teoria proposta por Dirac, que era agravada pela idéia artificial de mar infinito de elétrons, que não era bem aceita pela comunidade.

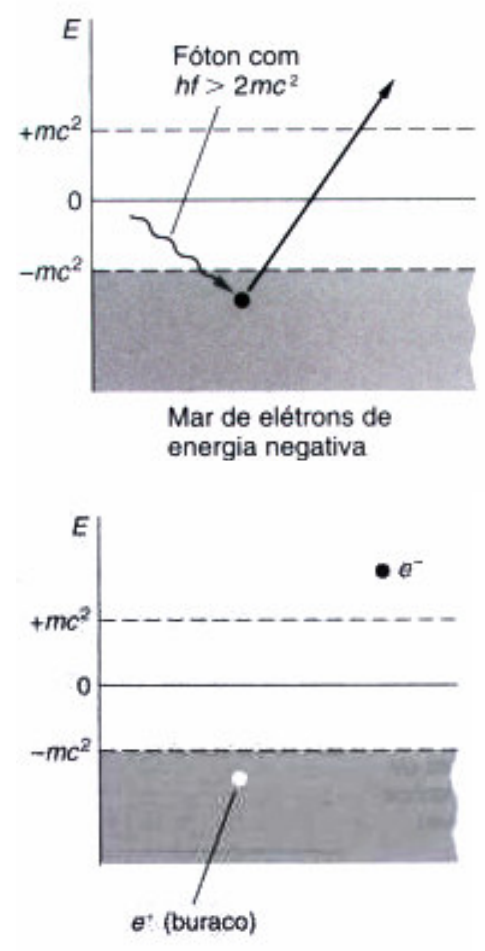


A validade dessa interpretação só veio em 1932, quando o americano Carl David Anderson (1905-1991), descobriu partículas com a mesma massa do elétron, porém de carga positiva, que foi denominada pósitron $\left(\boldsymbol{e}^{+}\right)$.

Anderson analisava rastros deixados por partículas em câmaras de nevoeiro no Instituto de Tecnologia da Califórnia (Caltech), quando percebeu o rastro deixado por um par de partículas com massas aparentemente iguais, mas com cargas opostas, identificando como a possível partícula procurada. Sendo confirmada em uma série de experiências posteriores confirmaram a descoberta do pósitron.

Contudo, a idéia de mar de elétrons não era muito confortável, sendo abandonada no final da década de 40, com o desenvolvimento da eletrodinâmica quântica (QED) por Richard Feynman (1918-1988) e Stukelberg que propuseram uma interpretação mais simples dos

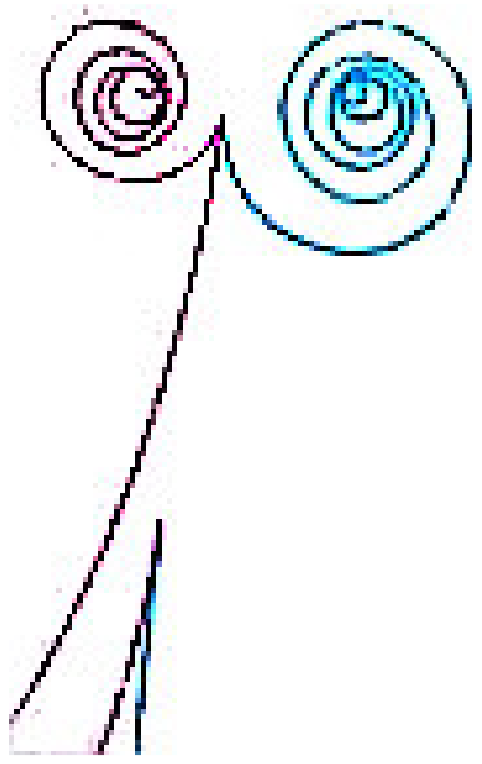
estados de energia negativa. As soluções correspondiam a antipartículas, ou seja, para cada partícula existe uma antipartícula com a mesma massa e carga de sinal contrário.

Assim, a nova teoria, previa também antiprótons e antinêutrons, por exemplo. Essas partículas foram detectadas respectivamente em 1955 e 1956, com a construção de aceleradores de partículas mais potentes.

Desta forma, estava consolidada a idéia de antipartículas e, a produção de antimatéria era só uma questão de tempo. Hoje em dia, a produção de anti-hidrogênio (pósitron + antipróton) é rotineiramente feita para pesquisa em grandes aceleradores.

\section{Produção e aniquilação: partícula x antipartícula}

Com a descoberta o pósitron e a nova interpretação dos estados negativos como antipartículas, abriu-se uma outra porta para produção de novas partículas.

Devido a relação entre massa-energia $\left(E=\mathrm{mc}^{2}\right)$, a produção de um par de partículaantipartícula só seria possível quando a energia do fóton $(\gamma)$ for maior ou igual a soma das massas de repouso de ambas partículas, que se quer produzir.

Um fóton de energia $E_{\gamma}$ maior do que $1,022 \mathrm{MeV}(2 \times 0,511$ $\mathrm{MeV} / \mathrm{c}^{2}$ ) pode interagir com um material criando um par elétronpósitron. A energia excedente se transforma em energia cinética do par elétron-pósitron, que atravessa o material perdendo energia sucessivamente por excitação ou ionizações de átomos.

Quando o pósitron perde toda a sua energia cinética e pára, ele

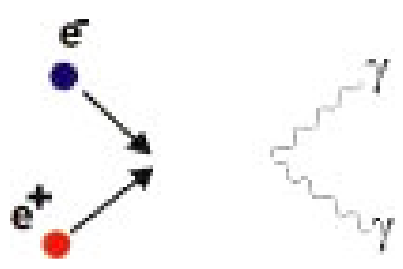
se aniquila com algum elétron, e há a emissão de dois raios gama de 0,511 MeV cada um. Para haver conservação de quantidade de movimento, os raios gama são emitidos em direções opostas.

$$
e^{-}+e^{+} \rightarrow \gamma+\gamma
$$


Questões:

1) Determine a energia mínima do fóton para que as seguintes reações ocorram:

a) $\gamma \rightarrow \Lambda^{+}+\pi^{-}$

b) $\gamma \rightarrow p+\bar{p}$

c) $\gamma \rightarrow \mu^{-}+\mu^{+}$

2) Os antiprótons quase sempre são aniquilados na reação $p+\bar{p} \rightarrow \gamma+\gamma$. Suponha que um próton e um antipróton se aniquilem em repouso. Por que devem ser produzidos dois fótons em vez de apenas um? 


\section{Teoria quântica de campos: uma nova concepção do campo eletromagnético}

As interações que ocorrem na natureza podem ser descritas através das quatro forças fundamentais: gravitacional, eletromagnética, fraca e forte.

A força gravitacional atua em corpos que possuem massa, porém ela só tem a sua ação revelada em corpos de massa muito grande, devido a sua baixa intensidade. Por isso, quando estudamos as partículas elementares, essa interação é praticamente descartada.

A força eletromagnética está presente nas interações que envolvem corpos com cargas elétricas. Ela é a responsável por elétrons girarem em torno do núcleo (positivo), por átomos se ligarem formando moléculas e assim, formar substâncias (como a água que bebemos) e corpos que vemos. Ela é responsável também por não atravessarmos paredes e corpos em geral, já que a maior parte dos átomos são vazios. Isso acontece porque os elétrons do nosso corpo são repelidos pelos elétrons da parede ou da cadeira em que você está sentado.

A interação fraca atua no interior das partículas (raio de ação da ordem de $10^{-18} \mathrm{~m}$ ), fazendo que as partículas sejam modificadas, trocando o sabor dos quarks. Ela está associada a carga "fraca" ou carga de "sabor".

A força forte atua em partículas que tem carga cor, ou seja, entre os quarks. Ela pode ser dividida em duas, a força forte fundamental, que mantém os quarks presos, formando as outras partículas (hádrons); a força forte residual, que mantém os nucleons (prótons e nêutrons) presos, formando o núcleo.

Podemos notar que toda força está associada a uma propriedade da partícula (carga). Força gravitacional - carga gravitacional (massa); força eletromagnética - carga elétrica; força fraca - carga fraca; força forte - carga cor.

A força pode ser interpretada como uma ação do campo associado a essas cargas, ou seja, cada carga das partículas tem um campo associado e, a ação dele se apresenta como uma força (interação).

Assim, a carga gravitacional (massa) tem associado a ela o campo gravitacional, a carga elétrica o campo eletromagnético, a carga fraca o campo fraco e a carga cor o campo forte. Para um corpo que tem carga elétrica e massa, ele terá os dois campos (gravitacional e eletromagnético). Mas como a carga elétrica está associada às partículas como próton e elétron, ele terá "internamente" um campo forte de curto alcance. Desta forma, o campo desse corpo será a sobreposição dos campos existentes nele.

Mas como descrever esses campos?

Vimos que a força forte é mediada por partículas que denominamos de glúons e a troca constante dessas partículas forma o campo forte (uma espécie de nuvem de glúons), isto é, o campo forte é formado por grânulos (glúons) trocados entre as partículas com carga cor. Por isso, podemos dizer que o campo forte é quantizado e o glúon é o quantum (o grânulo) do campo.

A mesma coisa, podemos ver no campo fraco. A troca de bósons $\left(\mathrm{W}^{+}, \mathrm{W}^{-}\right.$e $\left.\mathrm{Z}^{0}\right)$ entre as partículas, forma uma região de interação fraca entre as partículas, constituindo o campo fraco (nuvem de bósons), sendo o bóson o quantum desse campo.

Nessa concepção como seria descrito o campo eletromagnético e gravitacional? Quem é o quantum desses campos?

A teoria quântica dos campos prevê também um campo quantizado para o eletromagnético e o gravitacional com seus respectivos quantum, ou seja, uma descrição da interação através da troca de partículas (interessante!). 
No caso do campo eletromagnético, a interação entra as partículas que têm carga elétrica é feita pelo fóton $(\gamma)$ virtual $^{56}$. Assim, o campo de uma carga é formado por uma "nuvem" de fótons, que são emitidos e reabsorvidos por ela.

A primeira evidência da "existência" dos fótons ocorreu em 1905, quando Einstein explicou, a partir de evidências experimentais, o efeito fotoelétrico, atribuindo à luz propriedades corpusculares, através da hipótese de que sua energia é armazenada em pequenos pacotes: os fótons. Além disso, podemos dizer que é através da troca de fótons que uma carga elétrica sente a presença da outra, sendo, portanto o fóton o grande mediador da interação eletromagnética, ou seja, o fóton é como um carteiro que leva a carta denunciando a presença de uma partícula carregada para a outra.

Teríamos assim, o campo eletromagnético quântico no qual um elétron está cercado por uma nuvem de fótons, que o emite e o reabsorve; o segundo elétron está imerso nessa nuvem e pode absorver uma das partículas que o primeiro emite. Quando isso acontece, cada um dos elétrons é informado da existência do outro. Essa troca de fótons entre eles é a interação.

O fóton é uma partícula sem massa, e é por isso que o campo eletromagnético tem alcance infinito, seu spin é inteiro (1) como todo mediador de interação e não possui carga.

A quantização do campo também é prevista para o campo gravitacional. Neste caso a troca da partícula seria dado por quase todas as partículas, já que a grande maioria tem massa. O quantum do campo gravitacional é denominado gráviton (partícula de massa nula e spin inteiro - 2), mas essa partícula ainda não foi detectada, deixando uma lacuna a ser comprovada nessa teoria. Acredita-se que isso é somente uma questão de tempo e de melhoria dos detectores que se tornarão mais sensíveis.

\section{Questão:}

1) Qual a importância dos fótons dentro dessa "nova" (campo quantizado) forma de descrever a interação eletromagnética?

2) Qual é o papel do quantum (agente da interação) em cada tipo de interação, na nova maneira de descrever o campo?

\footnotetext{
${ }^{56}$ Virtual porque não pode ser detectado, pois são emitidos e absorvidos num intervalo de tempo muito curto, deste modo, as partículas que o emite ou o absorve, não perdem energia e não sofrem recuo, fazendo com que não viole o princípio da conservação de energia e momento.
} 


\section{Diagramas de Feynman: uma nova maneira de ver as interações}

Nas teorias quânticas, quando se calcula a possibilidades de ocorrer um certo evento na interação entre partículas, vários fatores devem ser levados em consideração, complicando demais seus cálculos. Isso faz com que a solução encontrada não seja exata.

$\mathrm{Na}$ tentativa de chegar a valores cada vez melhores, os cientistas recorrem a um método de aproximações sucessivas, conhecido como método permutativo. Esse se baseia no acréscimo sucessivo de pequenas correções no valor determinado inicialmente (valor de $1^{\mathrm{a}}$ ordem). E aqui que entra os diagramas de Feynman.

Os diagramas de Feynman correspondem à amplitude de probabilidade $\left(1^{\mathrm{a}}\right.$ ordem $)$ de uma colisão ou decaimento entre as partículas, ou seja, descreve a maior possibilidade da maneira como as partículas interagem. Para a descrição do evento ser a mais correta, deve-se acrescentar amplitudes de ordem superiores.

Esses diagramas são extremamente versáteis e simples para descrição de fenômenos eletromagnéticos. Por ser uma boa técnica foi levado para outras teorias como a cromodinâmica quântica (QCD).

As regras para desenhar os diagramas estão diretamente relacionadas às equações da eletrodinâmica quântica (QED).

Os diagramas são do tipo espaço-tempo, isto é, gráficos t em função de x. Esses eixos normalmente não são desenhados, porém iremos fazer uma visualização para você entender melhor, mas na apresentação dos exemplos, eles serão omitidos.Neles, teremos representado o tempo no eixo horizontal para cima e o espaço na vertical para cima.

As partículas são representadas por linhas retas com uma seta na ponta. Partículas cuja seta apontam no sentido negativo do eixo dos tempos são interpretados como antipartículas correspondente se movendo no sentido normal do tempo. As linhas são simbólicas e não representam as trajetórias das partículas.

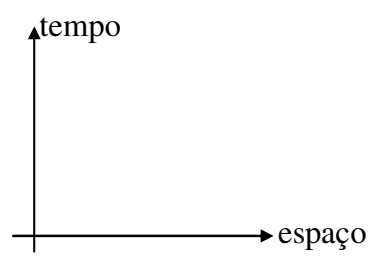
O nosso interesse com os diagramas, está na descrição das interações, tentando visualizar melhor o possível acontecimento (lembrando que o diagrama é somente uma das várias possibilidades possíveis da interação).

Para compreender melhor o uso dos diagramas, iremos discutir alguns diagramas, procurando entender melhor as diversas interações.

O diagrama 1 mostra como um elétron interagindo com o outro. No vértice da esquerda, o elétron emite um fóton virtual, que é absorvido por outro, no vértice da direita. Essa é a descrição da repulsão colombiana entre dois elétrons.

Já o diagrama 2, tem uma sutil diferença. Um elétron e um pósitron entram no vértice da esquerda e se aniquilam, produzindo um fóton. No vértice da direita, o fóton cria um par elétron-pósitron. Nesse diagrama é mostrado o processo de produção e aniquilação de partículas.

Esses dois exemplos ilustram bem como ocorre a interação eletromagnética entre partículas que têm carga elétrica. Ela se dá através da mediação do fóton $(\square)$.

Podemos também representar a interação entre as partículas do núcleo, os nucleons. Como mostra o diagrama 3. No vértice da esquerda, um nêutron emite um píon zero, que é absorvido por um outro nêutron no vértice da direita. Neste caso, ambos permanecem a mesma partícula. Essa mesma

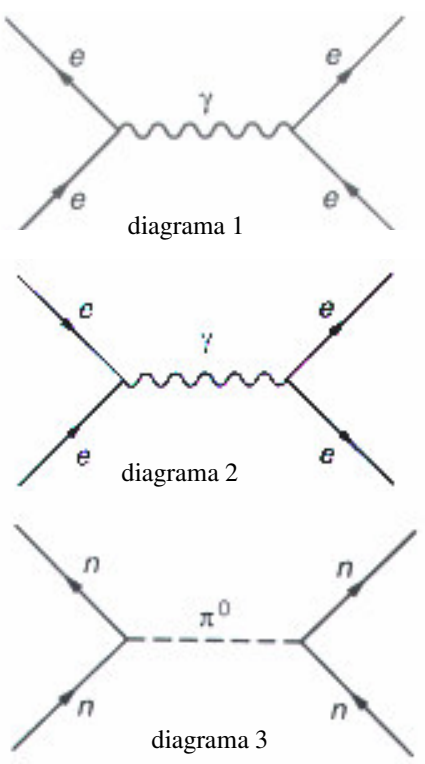


descrição pode ser feita no caso da interação próton-próton.

Agora no caso do diagrama 4, existe uma mudança da partícula, que mostra a interação próton-nêutron. No vértice da direita tem um próton que emite um píon mais e se torna um nêutron. Esse píon mais é absorvido por um nêutron que entra no vértice da esquerda, que se torna um próton. A descrição da interação nêutron-próton é contrária a essa.

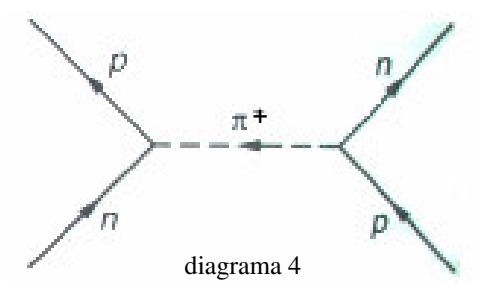
Essas são as descrições da interação forte entre os nucleons.

Agora, no diagrama 5, temos um dupla descrição de uma única partícula. Um nêutron emite um píon menos e se torna um próton que, por ser positivo, atrai eletromagneticamente o píon menos, se tornando novamente um nêutron.

Se quisermos, podemos também representar a interação entre os quarks, através da troca de glúons entre eles, como no caso do diagrama 6 . Nesse caso, vemos um quark up verde $(\mathrm{g})$, emitindo um glúon verde-antivermelho $(\mathrm{g}, \mathrm{r})$ e $\overline{\mathrm{se}}$ tornando um quark up vermelho (r).

Sabemos que os glúons são os mediadores da força forte e atuam em partículas que têm carga cor e como são coloridos (cor + anticor) podem interagir também entre si, trocando suas cores. Vemos essa interação entre os glúons no diagrama 7. Um quark emite um glúon que durante o intervalo de tempo que ele "existe", se torna outro dois glúons, que novamente se juntam, formando o glúons original e sendo absorvido pelo o quark que o emitiu.

Com essa representação, podemos descrever também o decaimento do nêutron em um próton, da seguinte reação:

$$
\mathrm{n} \rightarrow \mathrm{p}+\mathrm{e}^{-}+\overline{\mathrm{v}}_{\mathrm{e}}
$$

Essa representação pode ser vista no diagrama 8, onde um nêutron entra no vértice da esquerda, emite um bóson $\mathrm{W}^{-}$e se torna um próton. $\mathrm{O}$ bóson $\mathrm{W}^{-}$decai em um elétron e um antineutrino do elétron no vértice direito. Note que a seta que representa o neutrino do elétron está no sentido contrário ao eixo dos tempos, mostrando que é uma antipartícula.

Podemos ainda fazer uma representação mais detalhada do que acontece nesse decaimento, utilizando o modelo dos quarks, como é mostrado no diagrama 9. No vértice da esquerda, um quark down (d), se torna um quark up (u) emitindo um bóson $\mathrm{W}^{-}$, que logo decai em um elétron e um antineutrino do elétron.

Com a discussão de alguns diagramas, podemos notar que cada tipo de interação pode ser representa distintamente. Sempre com a preocupação de diferenciar os tipos de interações que ocorrem com seus mediadores (interação eletromagnética - fóton; interação forte fundamental - glúon; interação forte residual - píon e interação fraca - bóson).

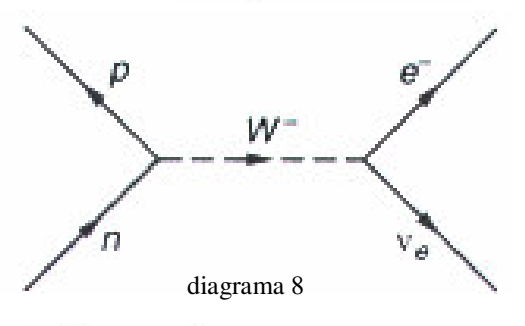

(p)

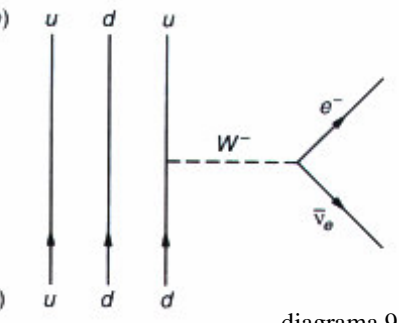


Lembremos que esses diagramas são representações e descrevem o que acontece com as partículas numa aproximação de $1^{\mathrm{a}}$ ordem, que deve ser acrescentada com contribuições de ordem superiores e, para cada acréscimo que se tem, a descrição se aproxima daquilo que pode ser a natureza. Vemos abaixo alguns diagramas de ordem maiores que dois, mostrando que a interação entre as partículas é muito mais complexa do que é descrita nos diagramas a cima, e para compreendê-las é preciso fazer todas as possíveis interações.
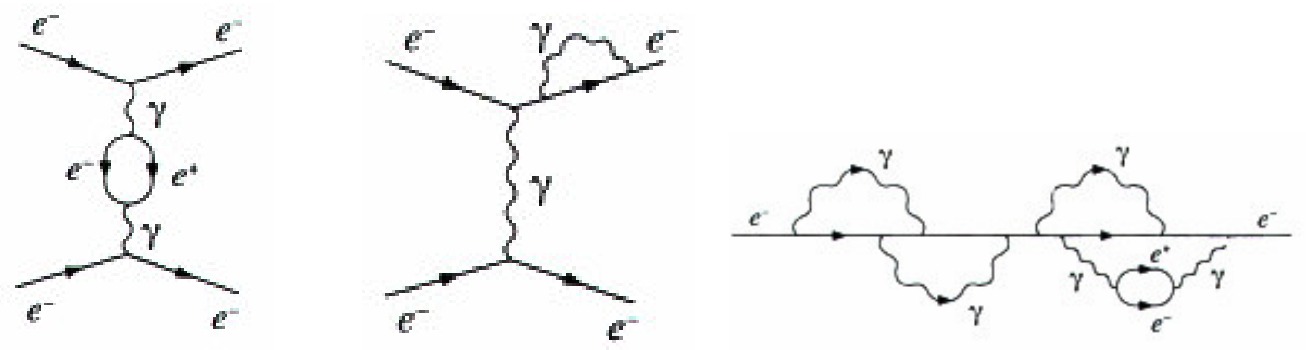

Questão: Tente descrever os diagramas de Feynman para as reações abaixo:

$$
\begin{aligned}
& \gamma \rightarrow \Lambda^{+}+\pi^{-} \\
& \gamma \rightarrow p+\bar{p} \\
& \gamma \rightarrow \mu^{-}+\mu^{+} \\
& \Lambda^{0} \rightarrow \pi^{-}+\mathrm{p}^{+}
\end{aligned}
$$




\section{Propriedades das partículas}

As partículas apresentam características que as fazem serem diferentes umas das outras. Essas características são as propriedades delas que servem para diferenciá-las e assim formar as famílias. Vamos apresentar agora, algumas dessas propriedades.

A primeira diferença notada entre as partículas foi à carga elétrica. A carga elétrica possui características muito interessantes, como possuir sinais contrários $(+\mathrm{e}-)$, poder ser somada (uma carga positiva neutraliza a ação de uma carga negativa, ou seja, + com -, dá zero), é sempre conservada (não se pode criar carga negativa sem criar uma positiva, ou seja, a quantidade de cargas de um sistema fechado é sempre a mesma)

Partículas que possuem carga elétrica estão sujeitas a interação eletromagnética, formando assim uma família de partículas que sofrem essa interação. Esse é o caso dos prótons e dos elétrons. Mas, como vimos, essas não são as únicas partículas que possuem carga, existem outras partículas como o Múon $\left(\mu^{-}\right)$, o Tau $(\tau)$, o Sigma mais $\left(\Sigma^{+}\right)$, o Delta mais $\left(\Delta^{+}\right)$e o Delta dois mais $\left(\Delta^{++}\right)$. Todas são partículas que têm carga elétrica.

Desta forma, vemos que a carga elétrica é uma propriedade muito importante neste estudo. É ela que vai indicar se a partícula sofre interação eletromagnética ou não. Partículas com carga nula, como o caso do nêutron, não são influenciadas por essa interação, dando indícios que existem outro tipo de interação para denunciar a presença dessas partículas. Concluímos também, que a carga elétrica, é dada em função da carga elétrica do elétron, que é a menor carga detectada isolada atualmente e por isso recebe o status de elementar ${ }^{57}$. Assim, o elétron e o próton ${ }^{58}$ têm cargas iguais a 1 , porém de sinais contrários. O próton é positivo e o elétron negativo. Por esse motivo, falamos que a carga elétrica é quantizada.

Aparece aqui outra questão, como fazemos para distinguir o elétron e as outras partículas que têm carga igual à -1 ?

Para responder essa questão temos que olhar para outra propriedade das partículas, a massa. Cada partícula possui uma massa característica dela e é através dela que se consegue diferenciar as partículas com a mesma carga. Para medir a massa dessas partículas, que é algo muito pequena, utilizamos uma unidade de medida que é peculiar ao estudo das partículas, o $\boldsymbol{M e V / c ^ { 2 }}$ (mega elétron-volt). O elétron-volt $(\mathrm{eV})$, significa a quantidade de energia adquirida por um elétron ao ser submetido a uma diferença de potencial de 1 volt (V) e o mega (M) é o prefixo grego que equivale a potência $10^{6}$, ou seja, um milhão. Essa unidade de medida deriva da "famosa" equação de Einstein $\left(E=\mathrm{mc}^{2}\right)$ para energia de repouso. Assim, vemos que a medida da massa das partículas é feita indiretamente através de suas energias.

É devido a massa, que grande parte das partículas possuem, que elas sofrem um outro tipo de interação, a interação gravitacional.

O spin fecha esse primeiro contato com as propriedades das partículas. O spin é uma grandeza quântica, com regras próprias de soma, mas que por enquanto podemos entender o spin como sendo o momento angular intrínseco da partícula que é como se a partículas estivesse girando. Para você entender melhor o que é spin, basta imaginar um pião rodando, ele executa um movimento de rotação sobre o seu eixo, esse seria o "spin do pião". Para se ter idéia da importância do spin, é graças a ele, que pode ser feita uma grande classificação das partículas, separando os agentes dos mediadores das interações, ou seja, quem transmite a mensagem e quais são os seus interlocutores. O spin é sempre medido em relação a constante

\footnotetext{
* versão preliminar

${ }_{58}^{57}$ Algo básico, primário e simples

${ }^{58}$ Vimos que apesar do próton ter carga de mesmo módulo que o elétron, ela não é considerada elementar, por ser constituído de quarks.
} 
de $^{\text {Planck }}{ }^{59}$ divido por $2 \pi(\hbar)$, possuindo valores positivos e negativos para algumas partículas.

Das partículas que conhecemos até agora, podemos fazer uma tabela, sistematizando as propriedades estudadas.

Tabela com as propriedades de algumas partículas

\begin{tabular}{l|ccc}
\hline \multicolumn{1}{c|}{ Partícula } & Carga elétrica $(\boldsymbol{e})$ & Spin $(\hbar)$ & $\begin{array}{c}\text { Massa de repouso } \\
\left({\left.\mathbf{M e V} / \mathbf{c}^{2}\right)}^{2}\right.\end{array}$ \\
\hline Elétron $\left(\mathrm{e}^{-}\right)$ & -1 & $1 / 2$ & 0,51 \\
Múon $\left(\mu^{-}\right)$ & -1 & $1 / 2$ & 106 \\
Tau $\left(\tau^{-}\right)$ & -1 & $1 / 2$ & 1784 \\
Próton $\left(\mathrm{p}^{+}\right)$ & +1 & $1 / 2$ & 938 \\
Sigma mais $\left(\Sigma^{+}\right)$ & +1 & $1 / 2$ & 1189 \\
Delta mais $\left(\Delta^{+}\right)$ & +1 & $3 / 2$ & 1235 \\
Delta dois mais $\left(\Delta^{++}\right)$ & +2 & $3 / 2$ & 1233 \\
Nêutron $(\mathrm{n})$ & 0 & $1 / 2$ & 938 \\
Fóton $(\gamma)$ & 0 & 1 & 0 \\
Píon mais $\left(\pi^{+}\right)$ & +1 & 1 & 140 \\
Píon menos $\left(\pi^{-}\right)$ & -1 & 1 & 140 \\
\hline
\end{tabular}

\section{Questões:}

1) Você conseguiria propor outros critérios (propriedades) para auxiliar na classificação das partículas?

2) Haveria uma maneira de diferenciar partículas com mesmo spin e mesma massa? Qual?

\footnotetext{
${ }^{59}$ Constante que domina o mundo microscópico, ou melhor, o mundo atômico. Seu valor é h = 6,62 x $10^{-34} \mathrm{~J} . \mathrm{s}$ (unidade de momento angular)
} 


\section{As famílias das partículas}

Vimos que as interações entre as partículas são mediadas por outras partículas. A força eletromagnética é mediada pela troca de fótons virtuais $(\gamma)$; a força gravitacional é mediada pela troca dos supostos grávitons; a força forte é mediada pela troca de glúons $(\mathrm{g})$ e a força fraca é mediada pelos bósons $\mathrm{W}^{+}, \mathrm{W}^{-}$e $\mathrm{Z}^{0}$.

Essas partículas que mediam as forças têm uma propriedade em comum, que diferenciam das demais partículas. Essa propriedade é o spin.

O spin dessas partículas é inteiro, fazendo que elas se agrupem, constituindo uma família, que é denominada bósons. Assim, bóson é o nome genérico de todas as partículas que são mediadoras de forças e que têm spin inteiro.

A tabela resume o que foi falado sobre as interações e seus mediadores até agora.

\begin{tabular}{|c|c|c|c|c|c|c|c|c|}
\hline \multicolumn{2}{|c|}{ Interação } & $\begin{array}{c}\text { Bóson } \\
\text { mediador }\end{array}$ & $\begin{array}{l}\text { Fonte da } \\
\text { interação }\end{array}$ & $\begin{array}{c}\text { Carga } \\
\text { elétrica }(e)\end{array}$ & $\begin{array}{l}\text { Spin } \\
(\hbar)\end{array}$ & $\begin{array}{c}\text { Alcance } \\
(\mathrm{m})\end{array}$ & $\begin{array}{c}\text { Tempo de } \\
\text { interação } \\
(s)\end{array}$ & $\begin{array}{c}\text { Intensida } \\
\text { de relativa }\end{array}$ \\
\hline \multicolumn{2}{|c|}{ Gravitacional } & Gráviton (?) & Massa & 0 & 2 & Infinito & - & $10^{-40}$ \\
\hline \multicolumn{2}{|c|}{ Eletromagnética } & Fóton & $\begin{array}{l}\text { Carga } \\
\text { elétrica }\end{array}$ & 0 & 1 & Infinito & $10^{-18}$ & $10^{-2}$ \\
\hline \multirow{2}{*}{ Forte } & Fundamental & Glúons & Carga cor & 0 & 1 & $10^{-15}$ & $10^{-23}$ & 1 \\
\hline & Residual & Mésons & Carga cor & 0 & 1 & $10^{-15}$ & $10^{-23}$ & 1 \\
\hline \multirow{2}{*}{\multicolumn{2}{|c|}{ Fraca }} & $\mathrm{W}^{-}, \mathrm{W}^{+}$ & Carga fraca & $-1,+1$ & 1,1 & $10^{-18}$ & $10^{-16}$ & $10^{-12}$ \\
\hline & & $Z^{0}$ & Carga fraca & 0 & 1 & $10^{-18}$ & $10^{-10}$ & $10^{-12}$ \\
\hline
\end{tabular}

Os bósons por possuírem spin inteiro não obedecem ao princípio da exclusão de Pauli, por isso eles podem ser encontrados no mesmo nível de energia, ou seja, podemos ter vários bósons no mesmo nível de energia. Essa propriedade, explica a produção do laser (Light $\boldsymbol{A}$ mplification by $\boldsymbol{S}$ timulated $\boldsymbol{E}$ mission of $\boldsymbol{R}$ adiotion), que nada mais é do que a emissão de fótons com mesma energia.

As demais partículas, têm o spin fracionário, formando um outro grupo ou família de partículas, denominadas Férmions.

Como os férmion possuem spin fracionário $(1 / 2,3 / 2, \ldots)$ eles obedecem o princípio da exclusão de Pauli, ou seja, não podemos ter férmions com mesmo nível de energia, enquanto partes de um todo, como por exemplo, os quarks no interior das partículas e os elétrons nas camadas da eletrosfera.

Os férmions elementares são os quarks com sabor up, down, strange, charm, bottom e top e os léptons com sabor elétron, neutrino do elétron, múon, neutrino do múon, tau e neutrino do tau. Essas partículas estão separadas em gerações, como mostra a tabela:

\begin{tabular}{r|cc}
\hline Geração & Quark & Lépton \\
\hline \multirow{2}{*}{$\mathbf{1}^{\mathbf{a}}$} & up (u) & elétron $\left(\mathrm{e}^{-}\right)$ \\
& down (d) & neutrino do elétron $\left(\mathrm{v}_{\mathrm{e}}\right)$ \\
\cline { 2 - 3 } $\mathbf{2}^{\mathbf{a}}$ & strange (s) & múon $\mu^{-}$ \\
& charm (c) & neutrino do múon $\left(v_{\mu}\right)$ \\
\cline { 2 - 3 } $\mathbf{3}^{\mathbf{a}}$ & bottom (b) & tau $\tau^{-}$ \\
& top (t) & neutrino do tau $\left(v_{\tau}\right)$ \\
\hline
\end{tabular}




\begin{tabular}{r|cc}
\hline Geração & Antiquark & Antilépton \\
\hline \multirow{2}{*}{$\mathbf{1}^{\mathrm{a}}$} & $\begin{array}{c}\text { antiup }(\bar{u}) \\
\text { antidown }(\bar{d})\end{array}$ & $\begin{array}{c}\text { pósitron }\left(\mathrm{e}^{+}\right) \\
\text {antineutrino do elétron }\left(\overline{v_{e}}\right)\end{array}$ \\
\cline { 2 - 3 } $\mathbf{2}^{\mathbf{a}}$ & $\begin{array}{cc}\text { antistrange }(\bar{s}) \\
\text { anticharm }(\bar{c})\end{array}$ & Antimúon $\left(\mu^{+}\right)$ \\
\cline { 2 - 3 } $\mathbf{3}^{\mathbf{a}}$ & antineutrino do múon $\left(\overline{\nu_{\mu}}\right)$ \\
\hline
\end{tabular}

A primeira geração de férmions $\left(\mathrm{u}, \mathrm{d}, \mathrm{e}^{-}, \mathrm{v}_{\mathrm{e}}\right)$ forma toda a matéria existente a nossa volta, junto com os bósons mediadores.

Tabela das propriedades dos Léptons e antiléptons

\begin{tabular}{|c|c|c|c|c|c|c|}
\hline Lépton & $\operatorname{spin}(\hbar)$ & $\operatorname{Massa}\left(\mathrm{MeV} / \mathrm{c}^{2}\right)$ & carga elétrica $(e)$ & $\boldsymbol{L}_{e}$ & $L_{\mu}$ & $L_{\tau}$ \\
\hline elétron $\left(\mathrm{e}^{-}\right)$ & $1 / 2$ & 0,511 & -1 & +1 & 0 & 0 \\
\hline neutrino do elétron $\left(v_{\mathrm{e}}\right)$ & $1 / 2$ & $\leq 0,016$ & 0 & +1 & 0 & 0 \\
\hline múon $\left(\mu^{-}\right)$ & $1 / 2$ & 107 & -1 & 0 & +1 & 0 \\
\hline neutrino do múon $\left(v_{\mu}\right)$ & $1 / 2$ & $\leq 0,25$ & 0 & 0 & +1 & 0 \\
\hline $\operatorname{tau}\left(\tau^{-}\right)$ & $1 / 2$ & 1777 & -1 & 0 & 0 & +1 \\
\hline neutrino do tau $\left(v_{\tau}\right)$ & $1 / 2$ & $\leq 35$ & 0 & 0 & 0 & +1 \\
\hline Antilépton & $\operatorname{spin}(\hbar)$ & $\operatorname{Massa}\left(\mathrm{MeV} / \mathrm{c}^{2}\right)$ & carga elétrica $(e)$ & $\boldsymbol{L}_{e}$ & $L_{\mu}$ & $L_{\tau}$ \\
\hline pósitron $\left(\mathrm{e}^{+}\right)$ & $1 / 2$ & 0,511 & +1 & -1 & 0 & 0 \\
\hline antineutrino do elétron $\left(\nabla_{\mathrm{e}}\right)$ & $1 / 2$ & $\leq 0,016$ & 0 & -1 & 0 & 0 \\
\hline antimúon $\left(\mu^{+}\right)$ & $1 / 2$ & 106 & +1 & 0 & -1 & 0 \\
\hline antineutrino do múon $\left(\bar{\nabla}_{\mu}\right)$ & $1 / 2$ & $\leq 0,25$ & 0 & 0 & -1 & 0 \\
\hline $\operatorname{antitau}\left(\tau^{+}\right)$ & $1 / 2$ & 1784 & +1 & 0 & 0 & -1 \\
\hline antineutrino do tau $\left(\overline{\nabla_{\tau}}\right)$ & $1 / 2$ & $\leq 35$ & 0 & 0 & 0 & -1 \\
\hline
\end{tabular}

$\boldsymbol{L}_{\boldsymbol{e}}$ : número leptônico do elétron

$\boldsymbol{L}_{\boldsymbol{\mu}}$ : número leptônico do múon

$\boldsymbol{L}_{i}$ : número leptônico do tau

Os quarks formam uma gama muito grande de partículas, que já vimos que são os hádrons (partículas formadas de quarks) e, essas partículas se dividem em dois grupos. Um formado pelos bárions, que são partículas que possuem 3 quarks e tem spin fracionário e, por isso também são férmions; o outro grupo, são os mésons, que são partículas formadas por um quark e um antiquark, possuindo spin inteiro (0 ou 1), sendo classificados como bósons.

Desta forma, os quarks formam hádrons que podem ser bárions (spin fracionário), que sãoférmions e, podem ser mésons (spin inteiro), que são bósons. 
Tabela das propriedades dos Quarks e Antiquarks

\begin{tabular}{|c|c|c|c|c|c|}
\hline Quark & $\operatorname{spin}(\hbar)$ & $\operatorname{Massa}\left(\mathrm{MeV} / \mathrm{c}^{2}\right)$ & carga elétrica $(e)$ & $n^{o}$ bariônico $(B)$ & Estranheza $(S)$ \\
\hline up (u) & $1 / 2$ & 3 & $+2 / 3$ & $+1 / 3$ & 0 \\
\hline down (d) & $1 / 2$ & 7 & $-1 / 3$ & $+1 / 3$ & 0 \\
\hline strange (s) & $1 / 2$ & 540 & $-1 / 3$ & $+1 / 3$ & -1 \\
\hline charm (c) & $1 / 2$ & 1250 & $+2 / 3$ & $+1 / 3$ & 0 \\
\hline bottom (b) & $1 / 2$ & 4700 & $-1 / 3$ & $+1 / 3$ & 0 \\
\hline top $(\mathrm{t})$ & $1 / 2$ & 174000 & $+2 / 3$ & $+1 / 3$ & 0 \\
\hline Antiquark & $\operatorname{spin}(\hbar)$ & $\operatorname{Massa}\left(\mathrm{MeV} / \mathrm{c}^{2}\right)$ & carga elétrica (e) & $n^{o}$ bariônico $(B)$ & Estranheza (S) \\
\hline $\operatorname{antiup}(\overline{\mathrm{u}})$ & $1 / 2$ & 3 & $-2 / 3$ & $-1 / 3$ & 0 \\
\hline antidown $(\overline{\mathrm{d}})$ & $1 / 2$ & 7 & $+1 / 3$ & $-1 / 3$ & 0 \\
\hline antistrange $(\overline{\mathrm{s}})$ & $1 / 2$ & 540 & $+1 / 3$ & $-1 / 3$ & +1 \\
\hline anticharm $(\overline{\mathbf{c}})$ & $1 / 2$ & 1250 & $-2 / 3$ & $-1 / 3$ & 0 \\
\hline antibottom $(\bar{b})$ & $1 / 2$ & 4700 & $+1 / 3$ & $-1 / 3$ & 0 \\
\hline antitop $(\bar{t})$ & $1 / 2$ & 174000 & $-2 / 3$ & $-1 / 3$ & 0 \\
\hline
\end{tabular}

Tabela das propriedades dos Bárions e Antibárions

\begin{tabular}{|c|c|c|c|c|c|c|}
\hline Bárion & quark & $\begin{array}{l}\text { spin } \\
(\hbar)\end{array}$ & $\begin{array}{c}\text { Massa } \\
\left({\left.\mathrm{MeV} / \mathrm{c}^{2}\right)}^{2}\right.\end{array}$ & $\begin{array}{c}\text { carga elétrica } \\
(e)\end{array}$ & $\begin{array}{c}n^{o} \text { bariônico } \\
(B)\end{array}$ & $\begin{array}{c}\text { Estranheza } \\
(S)\end{array}$ \\
\hline Próton (p) & uud & $1 / 2$ & 938 & +1 & +1 & 0 \\
\hline Neutron (n) & udd & $1 / 2$ & 938 & 0 & +1 & 0 \\
\hline Lambda zero $\left(\Lambda^{0}\right)$ & uds & $1 / 2$ & 1116 & 0 & +1 & -1 \\
\hline Sigma mais $\left(\Sigma^{+}\right)$ & uus & $1 / 2$ & 1189 & +1 & +1 & -1 \\
\hline Sigma zero $\left(\Sigma^{0}\right)$ & uds & $1 / 2$ & 1193 & 0 & +1 & -1 \\
\hline Sigma menos $\left(\Sigma^{-}\right)$ & dds & $1 / 2$ & 1197 & -1 & +1 & -1 \\
\hline Csi zero $\left(\Xi^{0}\right)$ & uss & $1 / 2$ & 1315 & 0 & +1 & -2 \\
\hline Csi menos $\left(\Xi^{-}\right)$ & dss & $1 / 2$ & 1321 & -1 & +1 & -2 \\
\hline Omega menos $\left(\Omega^{-}\right)$ & sss & $3 / 2$ & 1673 & -1 & +1 & -3 \\
\hline Delta dois mais $\left(\Delta^{++}\right)$ & uuu & $3 / 2$ & 1233 & +2 & +1 & 0 \\
\hline Antibárion & quark & $\begin{array}{l}\text { spin } \\
(\hbar)\end{array}$ & $\begin{array}{c}\text { Massa } \\
\left({\left.\mathrm{MeV} / \mathrm{c}^{2}\right)}^{2}\right.\end{array}$ & $\begin{array}{c}\text { carga elétrica } \\
(e)\end{array}$ & $\begin{array}{c}n^{o} \text { bariônico } \\
(B)\end{array}$ & $\begin{array}{c}\text { Estranheza } \\
\text { (S) }\end{array}$ \\
\hline antipróton (p) & uud & $1 / 2$ & 938 & -1 & -1 & 0 \\
\hline antineutron (n) & udd & $1 / 2$ & 938 & 0 & -1 & 0 \\
\hline antilambda zero $\left(\Lambda^{0}\right)$ & uds & $1 / 2$ & 1116 & 0 & -1 & +1 \\
\hline antisigma menos $\left(\Sigma^{-}\right)$ & uus & $1 / 2$ & 1189 & -1 & -1 & +1 \\
\hline
\end{tabular}




\begin{tabular}{l|cccccc}
\hline antisigma zero $\left(\Sigma^{0}\right)$ & uds & $1 / 2$ & 1193 & 0 & -1 & +1 \\
antisigma mais $\left(\Sigma^{+}\right)$ & dds & $1 / 2$ & 1197 & +1 & -1 & +1 \\
anticsi zero $\left(\Xi^{0}\right)$ & uss & $1 / 2$ & 1315 & 0 & -1 & +2 \\
anticsi mais $\left(\Xi^{+}\right)$ & dss & $1 / 2$ & 1321 & +1 & -1 & +2 \\
antiomega mais $\left(\Omega^{+}\right)$ & sss & $3 / 2$ & 1673 & +1 & -1 & +3 \\
\hline
\end{tabular}

Tabela das propriedades dos Mésons

\begin{tabular}{l|cccccc}
\hline Méson & Quark & $\begin{array}{c}\text { spin } \\
(\hbar)\end{array}$ & $\begin{array}{c}\text { Massa } \\
\left(\mathbf{M e V / c ^ { 2 }}\right)\end{array}$ & $\begin{array}{c}\text { carga elétrica } \\
(\boldsymbol{e})\end{array}$ & $\begin{array}{c}\boldsymbol{n}^{\boldsymbol{o}} \text { bariônico } \\
(\boldsymbol{B})\end{array}$ & $\begin{array}{c}\text { Estranheza } \\
(\boldsymbol{S})\end{array}$ \\
\hline Píon mais $\left(\pi^{+}\right)$ & $u \bar{d}$ & 0 & 140 & +1 & 0 & 0 \\
Píon menos $\left(\pi^{-}\right)$ & $\bar{u} d$ & 0 & 140 & -1 & 0 & 0 \\
Píon zero $\left(\pi^{0}\right)$ & $\bar{u} u$ & 0 & 1356 & 0 & 0 & 0 \\
Káon mais $\left(\mathrm{k}^{+}\right)$ & $u \bar{s}$ & 0 & 494 & +1 & 0 & +1 \\
Káon zero $\left(\mathrm{k}^{0}\right)$ & $d \bar{s}$ & 0 & 498 & 0 & 0 & +1 \\
Káon menos $\left(\mathrm{k}^{-}\right)$ & $\bar{u} s$ & 0 & 494 & -1 & 0 & -1 \\
Eta zero $\left(\eta^{0}\right)$ & $d \bar{d}$ & 0 & 549 & 0 & 0 & 0 \\
\hline
\end{tabular}




\section{ATIVIDADE 0}

\section{Objetivo: Estimular a discussão sobre as particulas e a curiosidade por aprender mais}

Esta atividade introduz o estudo no campo das partículas elementares e interações fundamentais. Ela tem o intuito de desafiar seus conhecimento e concepções acerca dos fundamentos da física dessa área. O questionário traz afirmações que você pode concordar (sim), pode descordar (não) ou pode não saber nada sobre a afirmação (não sei) e está desenhado para despertar o seu interesse em aprender mais sobre este campo.

Não temos preocupação em testar os seus conhecimentos sobre o assunto. Queremos fazer somente um levantamento do que é conhecido por você no início e no final do curso.

Nome:

Série:

Turma:

Data:

SIM NÃO NÃO SEI

1. O átomo é a menor estrutura conhecida e não pode ser dividida.

2. As forças fundamentais da natureza são: eletromagnética e gravitacional.

3. Existem partículas subatômicas que não têm massa nem carga elétrica.

4. Algumas partículas podem viajar através de bilhões de quilômetros de matéria sem ser detectadas (sem interagir).

5. A antimatéria é ficção científica e não um fato científico.

6. Os aceleradores de partículas são usados para o tratamento do câncer.

7. Os menores componentes do núcleo de um átomo são os prótons e os elétrons.
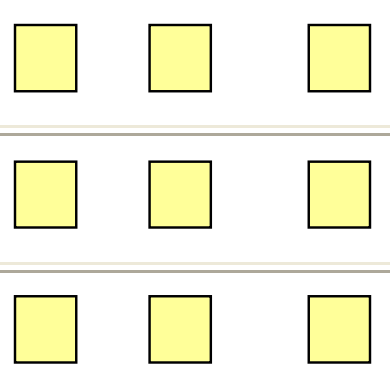

8. As partículas e as antipartículas podem se materializar a partir de energia.

9. Os Físicos de partículas necessitam de aceleradores maiores para poderem investigar objetos cada vez maiores.

10. Nos aceleradores circulares os imãs são usados para que as partículas se movam mais rápido.
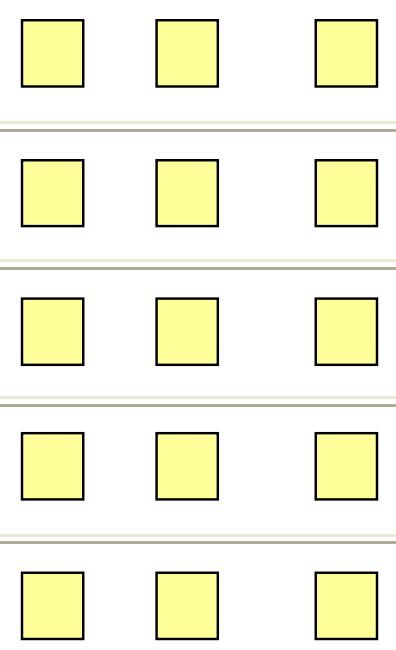

11. O trabalho feito pelos Físicos de partículas nos aceleradores
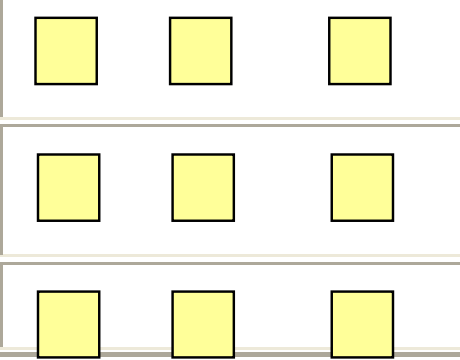


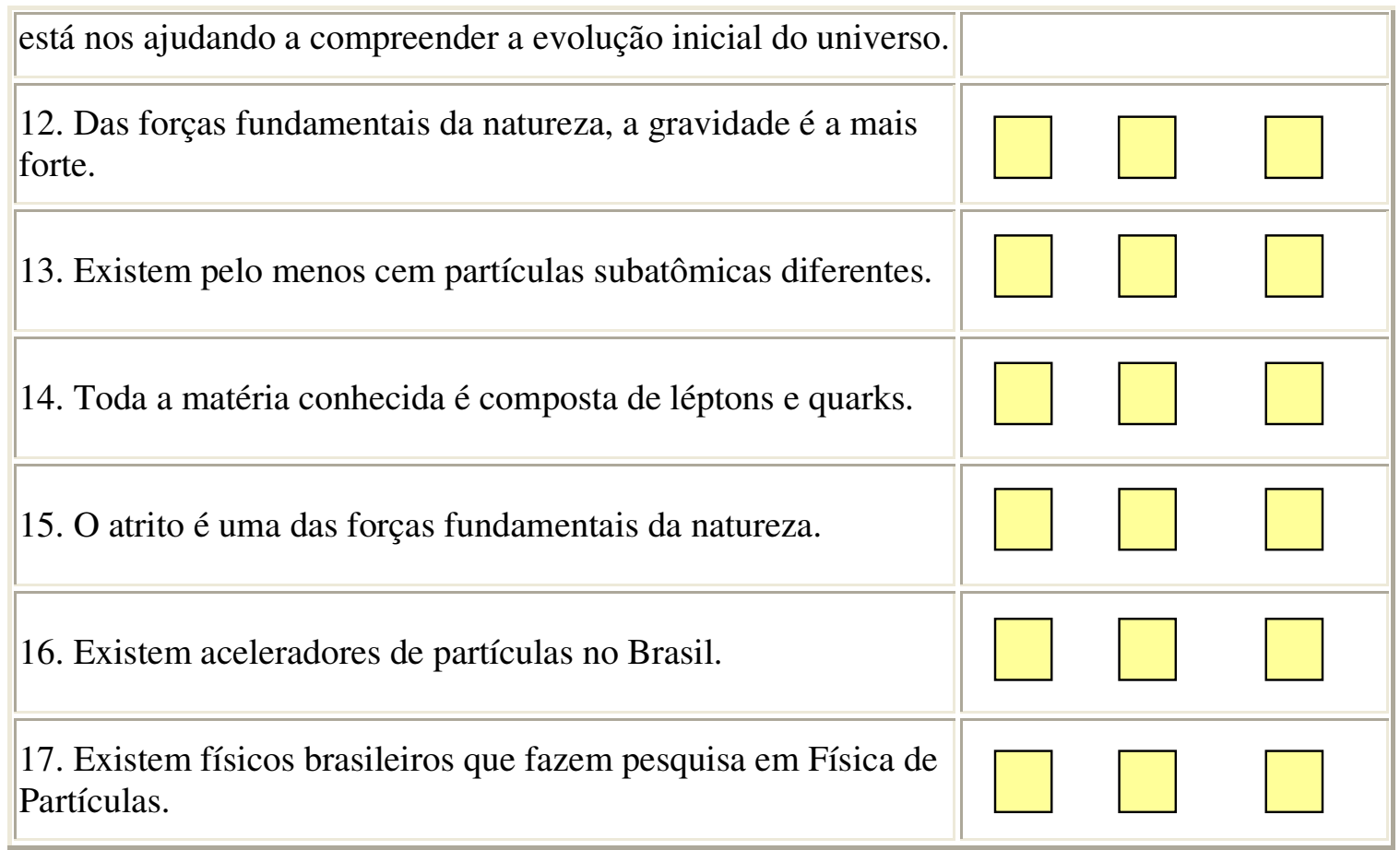




\section{ATIVIDADE 1}

\section{Discussão sobre os Raios X e a radiografias}

Essa atividade tem o intuito de discutir um pouco as radiografias e o processo dos raios $\mathrm{X}$, sendo a porta de entrada para iniciarmos nossa caminhada sobre o fantástico mundo da Física de Partículas.

\section{$1^{\text {a }}$ Parte: Analise das radiografias}

Depois de ter entendido um pouco como é o processo das radiografias, aqui, discutiremos melhor através das próprias radiografias.

Material: Diversas radiografias

Procedimento: Você irá receber algumas radiografias. Olhe-as com calma e procure fazer uma analise de suas peculiaridades (forma, nitidez, parte do corpo que pertence, se é de homem ou mulher, se pode identificar alguma doença e outras coisas que te chamam a atenção). Discuta essas características com seus colegas.

\section{Questões:}

1) Qual foi à radiografia que chamou mais sua atenção? Por que?

2) Por que se têm regiões mais claras e mais escuras?

3) Por que algumas radiografias apresentam melhor nitidez?

4) Como são produzidos os Raios $X$ ? 
5) Você sabe como e quando foram descobertos?

$2^{\text {a }}$ Parte: Absorção da luz pelo papel fotográfico

Nessa parte faremos uma "simulação" da produção de uma radiografia, através de papel fotográfico sensível à luz e objetos opacos.

Material:

Uma folha de papel fotográfico

Alguns objetos de formas e materiais diferentes

Um "abajur" de lâmpada

Procedimento: Você está recebendo uma folha de papel fotográfico, que é sensível a luz, coloque alguns objetos sobre o papel e aproxime-o de uma fonte luminosa intensa. Deixe alguns minutos, retire os objetos e observe o que aconteceu.

\section{Questões:}

1) Você pode distinguir bem a forma dos objetos? Por que?

2) Nas marcas deixadas pelas formas no papel, existe diferença enquanto a nitidez? Tente explicar essa diferença.

Sugestão de atividade: Procure uma pessoa que trabalhe com raios- $\mathrm{X}$ e radiografias e converse com ele sobre os tipos de chapas fotográficas e como elas são reveladas. 


\section{ATIVIDADE 2}

\section{Ordem de Grandeza e potência de 10}

Neste novo assunto que começamos a tratar, será quase que inevitável, a utilização de valores muito pequenos ou muito grandes, que não fazem parte de valores utilizados no nosso cotidiano. Por exemplo, se alguém lhe dissesse que o tamanho de um átomo é aproximadamente $0,0000000001 \mathrm{~m}$, você dificilmente assimilaria essa idéia, por se trata de um valor totalmente fora daqueles utilizados por você.

Números dessa forma podem ser representados de outra maneira, de tal maneira que a idéia que ele queira transmitir seja melhor interpretada e comparada. Além disso, torna-se mais fácil de se fazer operações com eles. Essa nova maneira de representar os números é a notação científica.

Com essa nova forma de representação numérica, podemos escrever qualquer número como uma potência de 10, sem que ele perca o seu valor original. Assim, fica mais fácil de opera-lo e compara-lo, tornando-se mais acessível ao nosso sentido.

Veja alguns exemplos de como representamos valores em notação científica

$$
\begin{aligned}
& 20000 \mathrm{~m}=2 \times 10000=2 \times 10^{4} \mathrm{~m} \\
& 2300 \mathrm{~kg}=2,3 \times 1000 \mathrm{~kg}=2,3 \times 10^{3} \mathrm{~kg} \\
& 0,007 \mathrm{~cm}=\frac{7}{1000} \mathrm{~cm}=\frac{7}{10^{3}} \mathrm{~cm}=7 \times 10^{-3} \mathrm{~cm}
\end{aligned}
$$

Tente escrever os números abaixo em notação científica

a) o diâmetro do próton $0,000000000000001 \mathrm{~m}=$

b) o diâmetro do átomo $0,0000000001 \mathrm{~m}=$

c) a carga elétrica de um elétron - 0,000 $00000000000000016 \mathrm{C}=$

d) a massa de um nêutron 0,000 $00000000000000000000000167 \mathrm{~kg}=$

\section{$1^{a}$ Atividade: visualizando "o muito pequeno"}

\section{a) Cortando papel para chegar a prótons}

Objetivo: tentar dar uma idéia do tamanho dos objetos estudados na física de partículas.

Material: folha de papel A4, tesoura e régua.

Procedimento: Pegue a folha de papel e corte-a no meio. Com uma das metades, faça outro corte, também ao meio. Repita esse procedimento quantas vezes forem possíveis até chegar a um pedaço que você não consiga mais cortar. Conte os números de cortes feitos e faça a medida do menor pedaço de papel que você conseguiu. 


\section{b) Tamanhos dos objetos estudados em Física de Partículas}

Objetivo: ao examinar o tamanho relativo e o espaço entre partículas, os alunos adquirem a idéia dos tamanhos dos objetos estudados em Física de Partículas.

Se o núcleo de um átomo de hidrogênio fosse do tamanho da cabeça de um alfinete $(1 \mathrm{~mm})$, então o elétron no átomo estaria, aproximadamente, a uns $10 \mathrm{~m}$ de distância.

Algumas idéias básicas que podem ajudar os alunos na compreensão das dimensões atômicas e subatômicas:

- Um núcleo típico é 10 vezes maior do que um próton;

- Um átomo típico (o tamanho determinado pelos elétrons mais externos) é 10000 vezes maior que um núcleo típico;

- Uma cabeça de alfinete $\left(1 \mathrm{~mm}=10^{-3} \mathrm{~m}\right)$ é 10.000 .000 de vezes maior que um átomo típico;

- Na espessura de uma folha de papel A4, há, aproximadamente, $\quad 1.000 .000 \mathrm{de}$ átomos;

- Se um átomo fosse do tamanho de uma cabeça de alfinete, a espessura da folha de papel seria de $1.000 \mathrm{~m}$ ou $1 \mathrm{Km}$;

- Um próton tem massa, aproximadamente, 2000 vezes maior do que o elétron.

\section{Questões:}

1) Se sua casa fosse o núcleo do átomo, a que distância estaria seu vizinho mais próximo (elétron mais perto do núcleo)?

\begin{tabular}{|c|c|c|c|}
\hline DIMENSÃO & 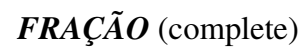 & DECIMAL & POTÊNCIA DE 10 \\
\hline $\begin{array}{l}\text { menor objeto visto a olho } \\
\text { nu }\end{array}$ & & $0,00001 \mathrm{~m}$ & $10^{-5} \mathrm{~m}$ \\
\hline $\begin{array}{l}\text { diâmetro aproximado de } \\
\text { um átomo }\end{array}$ & & $0,0000000001 \mathrm{~m}$ & $10^{-10} \mathrm{~m}$ \\
\hline $\begin{array}{l}\text { diâmetro aproximado de } \\
\text { um núcleo }\end{array}$ & & $0,00000000000001 \mathrm{~m}$ & $10^{-14} \mathrm{~m}$ \\
\hline $\begin{array}{l}\text { diâmetro aproximado de } \\
\text { um próton }\end{array}$ & & $0,000000000000001 \mathrm{~m}$ & $10^{-15} \mathrm{~m}$ \\
\hline
\end{tabular}




\section{$2^{a}$ Atividade: Tamanho dos corpos, através da potência de 10.}

Procedimento: entre no site do cern : (Power of ten)

http://microcosm.web.cern.ch/microcosm/P10/esp

Nele, você verá uma atividade que trabalha com potências de 10 (ordem de grandeza dos objetos), podendo visualizar os objetos para cada potência.

Anote o que você observa, conforme a potência de 10 que selecionou na régua, para os seguintes exemplos:

ordem de $10^{26}$ :

ordem de $10^{12}$ :

ordem de $10^{0}$ :

ordem de $10^{-8}$ :

ordem de $10^{-10}$ :

ordem de $10^{-14}$ :

ordem de $10^{-15}$ : 
Atividade 3

\section{O Descobrimento de Rutherford (espalhamento Rutherford)}

Nesta atividade, você e os membros de seu grupo usaram os métodos desenvolvidos por Ernest Rutherford no começo de 1900, e que, ainda são usados em nossos dias pelos físicos de partículas, em seus experimentos com aceleradores. Estes métodos permitem aos cientistas identificar as características de partículas que realmente não podem ser vistas. Você aprenderá o quanto melhor devem ser suas medidas, quando você não pode ver o objeto estudado.

$\mathrm{Na}$ mesa de experimentos de sua equipe há um tampo grande de madeira, debaixo do qual, foi colocada uma figura plana.

O trabalho de seu grupo é identificar a forma da figura sem vê-la. Você somente pode jogar bolinhas contra o objeto escondido, e observar a deflexão que se produz na trajetória das bolinhas depois de se chocar com a figura. Seu grupo terá cinco minutos para "observar" a figura.

Coloque um pedaço de papel sobre o tampo de madeira para esboçar a trajetória das bolinhas. Logo depois, analise esta informação para determinar a forma efetiva do objeto. Faça um pequeno desenho das figuras que o grupo analisou e responda as perguntas abaixo:

\section{Questões:}

1) Você pode determinar o tamanho e a forma do objeto?

2) Como poderia saber se as figuras têm detalhes em sua forma, que são pequenos comparados com o tamanho das bolinhas?

3) Como você pode confirmar suas conclusões sem olhar o objeto? 


\section{Atividade 5 \\ Entendendo a estrutura das partículas}

Já se sabe que os prótons e os nêutrons são constituintes do núcleo (núcleons) e eles se mantêm unidos, devido à força forte, que é descrita com a troca de píons $(\pi)$. Essa evidência levou a questionar o caráter elementar dos prótons e dos nêutrons, ou seja, que estes seriam constituídos de partes.

Nessa atividade você receberá um conjunto de figuras que têm formas e cores distintas, que representam partículas e tentará construir um modelo para os constituintes do próton e do nêutron.

\section{Material:}

12 quadrados de papel (4 verdes, 4 azuis e 4 vermelhos)

12 triângulos de papel (4 verdes, 4 azuis e 4 vermelhos)

\section{1a Parte:}

Procedimento: Utilizando, somente duas dessas figuras, procure estabelecer um modelo (uma lei ou regra) para a formação do núcleo de Hidrogênio - próton (carga: $+1^{*}$, spin: $1 / 2$ ). Para isso, você terá que atribuir valores para carga e o spin de cada forma geométrica.

Agora com esse modelo, monte o núcleo de Hélio - 2 prótons e 2 nêutrons (carga: nulo, spin: 1/2) e o núcleo de Lítio - 3 prótons e 4 nêutrons.

Enuncie sua regra:

Com essa regra, qual o número máximo de partículas distintas que você consegue "construir" com duas figuras? Dê as características (carga e spin) de cada uma.

Os constituintes (as duas figuras) obedecem ao princípio da exclusão de Pauli (duas partículas iguais não podem ocupar o mesmo estado quântico)? 


\section{$2^{\mathrm{a}}$ Parte:}

Procedimento: Repita todo os passos, agora, utilizando três figuras, agora sem repetir as cores. Utilizando as figuras, procure estabelecer um modelo (como uma lei ou regra) para a formação do núcleo de Hidrogênio - próton (carga: $+1^{*}$, spin: $1 / 2$ ).

Agora com esse modelo, monte o núcleo de Hélio - 2 prótons e 2 nêutrons (carga: nulo, spin: 1/2) e o núcleo de Lítio - 3 prótons e 4 nêutrons.

Enuncie sua regra:

Com essa regra, qual o número máximo de partículas distintas que você consegue "construir" com três figuras? Dê as características (carga e spin) de cada uma.

Os constituintes (as três figuras) obedecem ao princípio da exclusão de Pauli? 
ATIVIDADe 6

\section{As regras do jogo}

Os cientistas de todos os campos criam regras para explicar suas observações. Depois utilizam essas regras para interpretar novas observações. Essa atividade permite a vocês descobrirem novas regras que julguem ter um papel crucial no estudo da Física de Partículas: as leis de conservação.

O tipo mais comum de observação na Física de partículas se denomina evento. Evento é similar a uma reação química, no sentido que nela se forma um grupo de partículas a partir de outras.

As seguintes tabelas de partículas os ajudaram a identificar o tipo de carga das partículas que participam dos eventos representados abaixo. Como se indica, cada partícula pode ter carga elétrica $+1,-1$ ou 0 (em unidades de carga do elétron).

Note que as antipartículas estão indicadas, em alguns casos, mediante a uma barra colocada em cima do nome da partícula (exemplo., p-barra $=$ antipróton, $\mathrm{v}_{\mathrm{e}}$-barra $=$ antineutrino do elétron); em outros casos, estão indicadas simplesmente por um sinal das cargas $\left(\mathrm{e}^{-}=\right.$elétron, $\mathrm{e}^{+}=$posítron $=$antielétron $) ; \mathrm{pi}^{+}$e $\mathrm{pi}^{-}$são partícula e antipartícula respectivamente, e em forma similar, $\mathrm{K}^{+}$e $\mathrm{K}^{-}$. Uma antipartícula possui a mesma massa que sua correspondente partícula, mas suas cargas têm valor oposto.

\begin{tabular}{|cc|cccccc|}
\multicolumn{2}{c|}{ BÁRIONS } & \multicolumn{2}{c|}{ MÉSONS } & \multicolumn{2}{c|}{ LÉPTONS } & \multicolumn{2}{c|}{ FóTON } \\
\hline Símbolo & Carga & Símbolo & Carga & Símbolo & Carga & Símbolo & Carga \\
$\mathrm{p}$ & +1 & $\pi^{+}$ & +1 & $\mathrm{e}^{-}$ & -1 & $\gamma$ & 0 \\
$\mathrm{p}$ & -1 & $\pi^{-}$ & -1 & $\mathrm{e}^{+}$ & +1 & & \\
$\mathrm{n}$ & 0 & $\pi^{0}$ & 0 & $\mathrm{v}_{\mathrm{e}}$ & 0 & & \\
$\Delta$ & 0 & $\mathrm{k}^{+}$ & +1 & $\mathrm{v}_{\mathrm{e}}$ & 0 & & \\
& & $\mathrm{k}^{-}$ & -1 & & & & \\
& & $\mathrm{k}^{0}$ & 0 & & & & \\
\hline
\end{tabular}

Na tabela seguinte, são mostrados os conjuntos de eventos de partículas. No conjunto da coluna esquerda temos somente nos eventos que se sabe que irão ser produzidos. No entanto, no conjunto da coluna da direita, temos somente de eventos que se acreditam que não se pode produzir (de fato, estes eventos nunca foram observados).

Examinando os dois grupos, junto com a tabela anterior de partículas, devemos determinar quais quantidades são conservadas. Estas são "as regras do jogo" jogado pela natureza.

Todas as quantidades cuja conservação podem ser deduzidas a partir dos seguintes eventos, podem ser calculadas. Estas quantidades devem ser conservadas para todos os eventos "observados", mas ao menos uma delas não é conservada em cada evento "não observado".

Suponha que as partículas que entram na reação têm energia suficiente para gerar as partículas que saem. 


\section{$n \rightarrow p^{-} \bar{v}_{e}$}

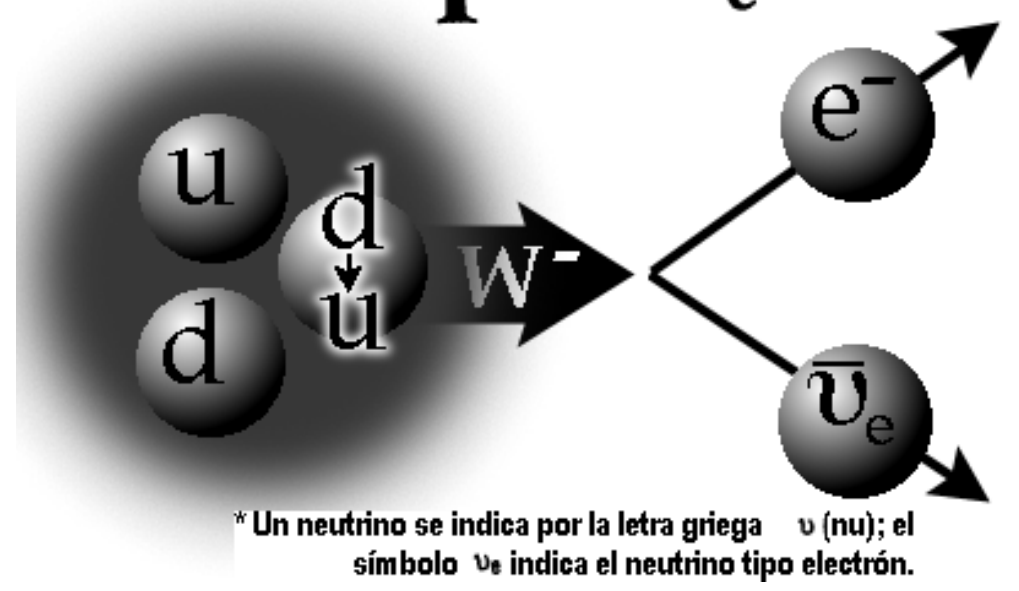

\section{Eventos Observados | Eventos Não Observados}

1. $\mathrm{n} \rightarrow \mathrm{p}+\mathrm{e}^{-}+\overline{\mathrm{v}}_{\mathrm{e}}$

16. $\mathrm{n}+\mathrm{p} \rightarrow \mathrm{p}+\mathrm{p}$

2. $\pi^{+}+n \rightarrow p+\pi^{0}$

17. $\mathrm{p} \rightarrow \pi^{0}+\pi^{+}$

3. $\pi^{-}+p \rightarrow n+\pi^{-}+\pi^{+}$

18. $\mathrm{p} \rightarrow \pi^{+}+\pi^{-}$

4. $\pi^{-}+\mathrm{p} \rightarrow \mathrm{p}+\pi^{0}+\pi^{-}$

19. $\pi^{+}+\mathrm{p} \rightarrow \mathrm{k}^{+}+\mathrm{k}^{0}$

5. $\Delta \rightarrow \mathrm{p}+\pi^{-}$

20. $\Delta \rightarrow \pi^{+}+\pi^{-}+\pi^{0}$

6. $\Delta \rightarrow \mathrm{n}+\pi^{0}$

21. $\Delta \rightarrow \mathrm{k}^{+}+\mathrm{k}^{-}$

7. $n+p \rightarrow p+p+\pi$

22. $\pi^{0}+\mathrm{n} \rightarrow \pi^{+}+\pi^{-}$

8. $p+p \rightarrow p+n+\pi^{+}$

23. $\pi^{0}+\mathrm{n} \rightarrow \mathrm{p}+\overline{\mathrm{p}}$

9. $\mathrm{e}^{-}+\mathrm{e}^{+} \rightarrow \mathrm{p}+\overline{\mathrm{p}}$

10. $\mathrm{e}^{-}+\mathrm{e}^{+} \rightarrow \gamma+\gamma$

24. $\Delta \rightarrow \mathrm{n}+\pi^{0}+\mathrm{v}_{\mathrm{e}}$

11. $\mathrm{p}+\overline{\mathrm{p}} \rightarrow \pi^{+}+\pi^{-}$

25. $\pi^{-} \rightarrow \mathrm{e}^{-}+\gamma$

12. $\Delta \rightarrow \mathrm{n}+\pi^{+}+\pi^{-}$

26. $\mathrm{e}^{-}+\gamma \rightarrow \mathrm{e}^{+}+\gamma$

13. $\pi^{0}+\gamma \rightarrow \pi^{+}+\pi^{-}$

27. $\mathrm{n} \rightarrow \gamma+\mathrm{e}^{-}+v_{\mathrm{e}}$

14. $\mathrm{p} \rightarrow \mathrm{n}+\mathrm{e}^{+}+\mathrm{v}_{\mathrm{e}}$

28. $\mathrm{e}^{+}+\gamma \rightarrow \mathrm{p}+\gamma$

15. $\mathrm{n}+\pi^{+} \rightarrow \mathrm{p}$

29. $\gamma+\gamma \rightarrow \mathrm{p}+\mathrm{n}$

30. $\Delta \rightarrow \mathrm{e}^{-}+\mathrm{v}_{\mathrm{e}}+\mathrm{p}$

\section{Questões:}

1) Que quer dizer uma quantidade que se conserva?

2) Que quantidade ou números dos distintos tipos de objetos se conservam? 
3) O que é um "evento" em Física de Partículas?

4) Quais dos eventos mostrados são decaimento?

5) Em cada um dos eventos não observados, indique qual é a quantidade que não se conserva? (pode ter mais de uma resposta).

Evento:

$16-$

21-

26-

$17-$

22-

27-

$18-$

23-

28-

$19-$

24-

29-

20-

25-

30- 
ATIVIDADe 7

\section{Analisando o sistema}

Quando os cientistas estudam qualquer sistema devem fazer duas perguntas básicas:

1) Quais são os objetos básicos, os "tijolos" que compõem este sistema?

2) Quais são as interações entre esses objetos?

A respostas a estas perguntas depende da escala na que você estuda o sistema. Os físicos de partículas a fazem na menor escala possível, buscando descobrir os "tijolos" (constituintes básicos) da matéria e as interações fundamentais entre elas.

As leis que descrevem estas interações, as forças básicas, explicam porque alguns objetos são observados e outros não. Para compreender os dados experimentais, são igualmente importantes as forças básicas e os constituintes. Os fatos que não se produzem, nos dão pistas tão importantes como aqueles que são produzidos.

Este enigma mostra o desafio que enfrentam os físicos de partículas. Imagine que o quebra-cabeça contenha informações sobre as partículas que foram obtidos nos aceleradores. As figuras negras representam objetos que são observados, no entanto, os brancos não são observados.

No quebra-cabeça, os objetos são todas formas bidimensionais e as interações são os modos como eles podem combinar (contato entre as formas básicas).

As formas não observadas lhe forneceram importantes pistas para as respostas.
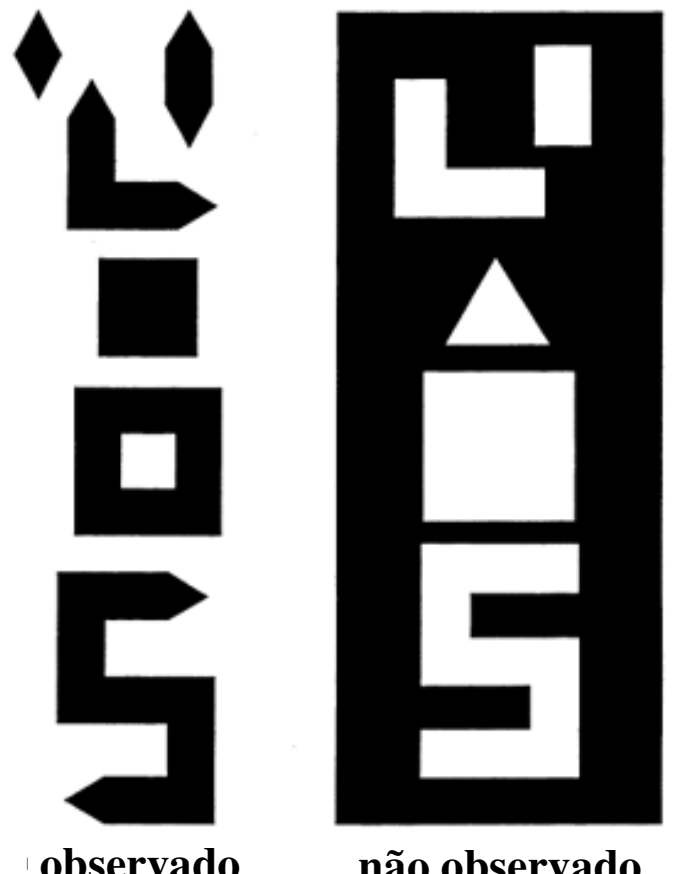

não observado 


\section{Questões:}

1) Quais sãos as formas elementares (formas básicas) que formam as figuras observadas?

2) Existe um padrão (lei) de conexão entre essas formas? (Com quem elas têm contato e quantos contatos são possíveis)

3) Por que não se pode observa as figuras brancas?

Note que você precisara responder ambas perguntas para poder explicar o porquê não é possível à existência dos objetos não observados. 

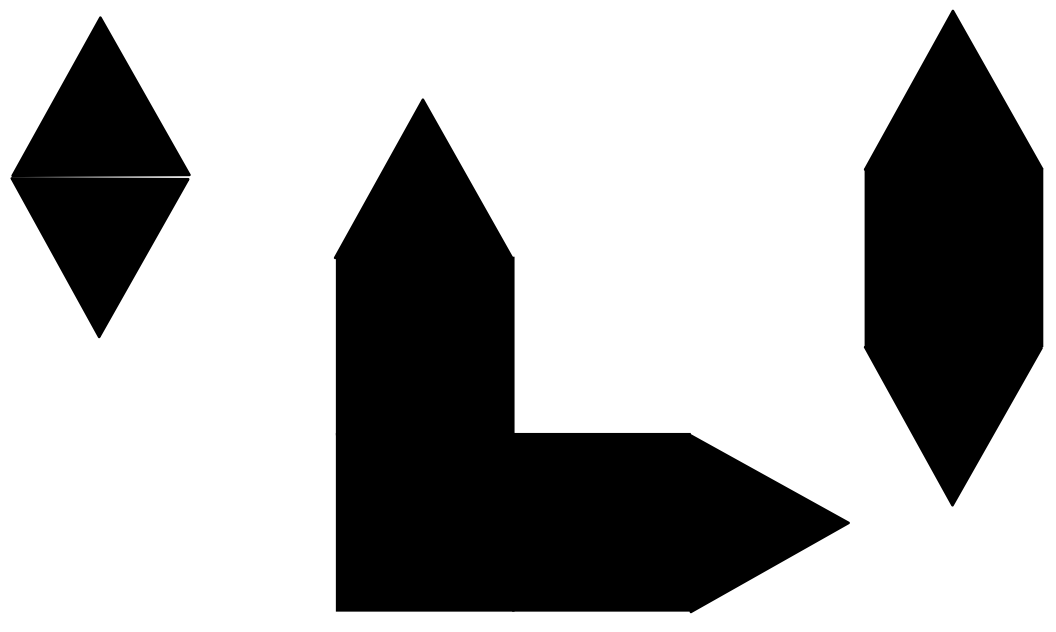

16
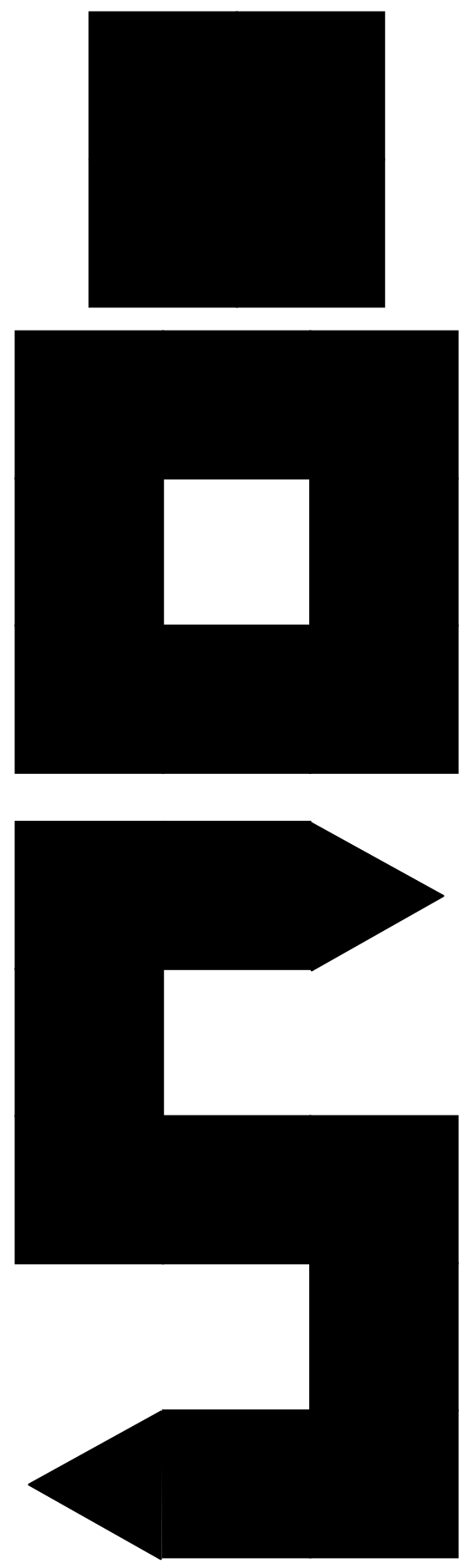


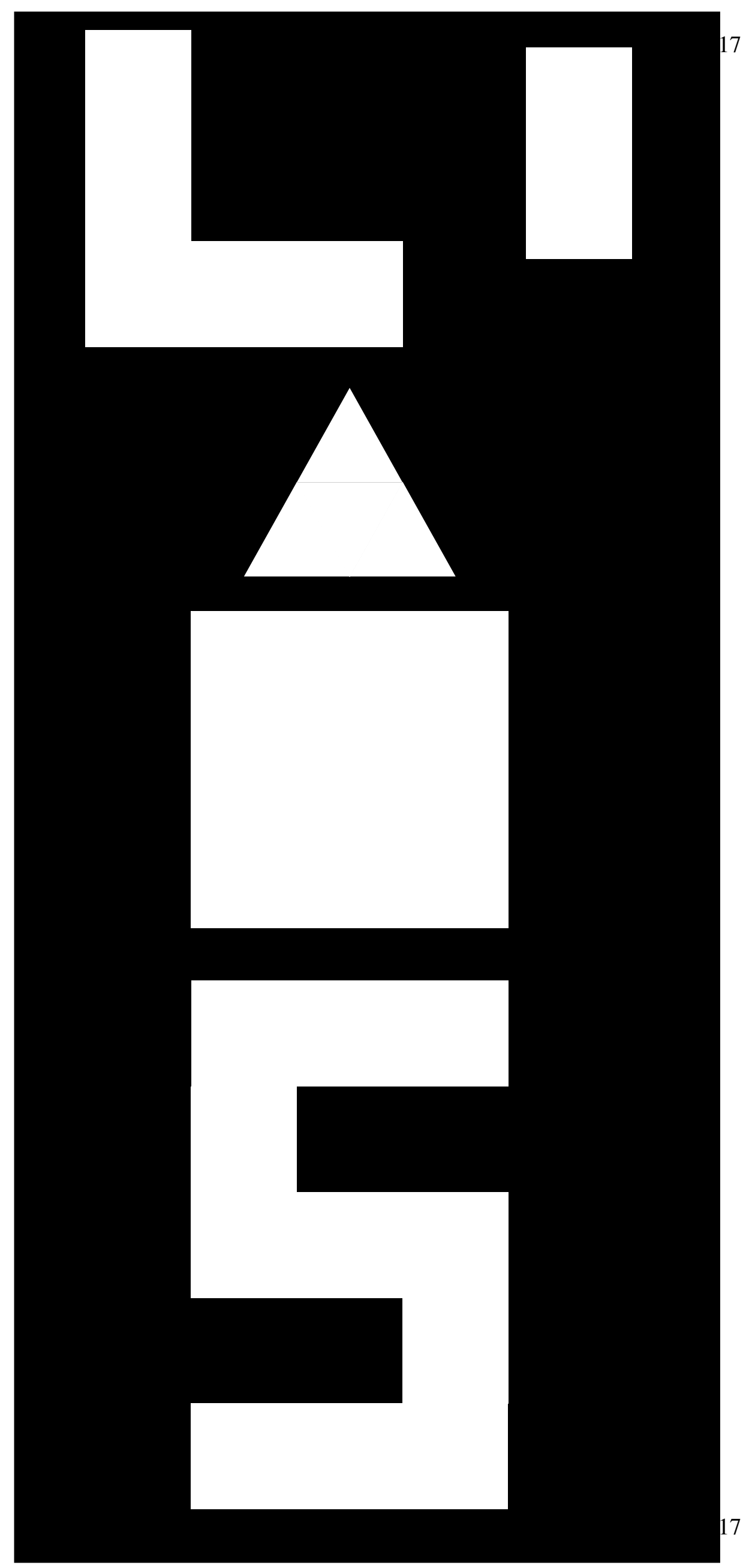




\section{Atividade 8 \\ O campo eletromagnético quantizado: o papel do fóton}

Essa atividade tentará descrever, através de uma analogia, o papel do fóton na interação eletromagnética, no âmbito da teoria quântica de campos, ou seja, com o campo quantizado.

Quando estudamos o campo eletromagnético em Física de Partículas, vimos que ele é.

\section{Material}

4 Pulverizadores de água

Procedimento : Coloque dois alunos parados um de costa para o outro, com pulverizadores de água, com os olhos vendados. Coloque mais dois alunos girando em volta daqueles que estão parados, há aproximadamente um metro. Estes também devem ter pulverizadores.

Peça que os quatro comecem a pulverizar água, de forma que as gotículas atinjam tanto os que estão parados quanto os que estão girando.

Essas gotículas, representam os fótons, que são trocados entre as partículas que possuem carga elétrica (os alunos parados - núcleons e girando - elétrons). 


\section{Atividade 9}

\section{Montagem do mapa conceitual}

Essa é a atividade que encerra nosso passeio pelo mundo da Física de Partículas. Nela, tentaremos sistematizar algumas idéias que podem ter ficando soltas ao longo do caminho.

Por isso tentaremos montar esse mapa conceitual, que irá auxiliar na compreensão dos conceitos estudados.

Material: vários quadrados de papel com os conceitos mais importantes da Física de Partículas, como: força forte, fraca, eletromagnética e gravitacional, glúons, quarks, léptons entre outros.

Procedimento: Recorte os quadrados abaixo.

De posse desses quadrados, tente conectá-los de uma forma coerente com o que foi estudado. Lembre da classificação das partículas.

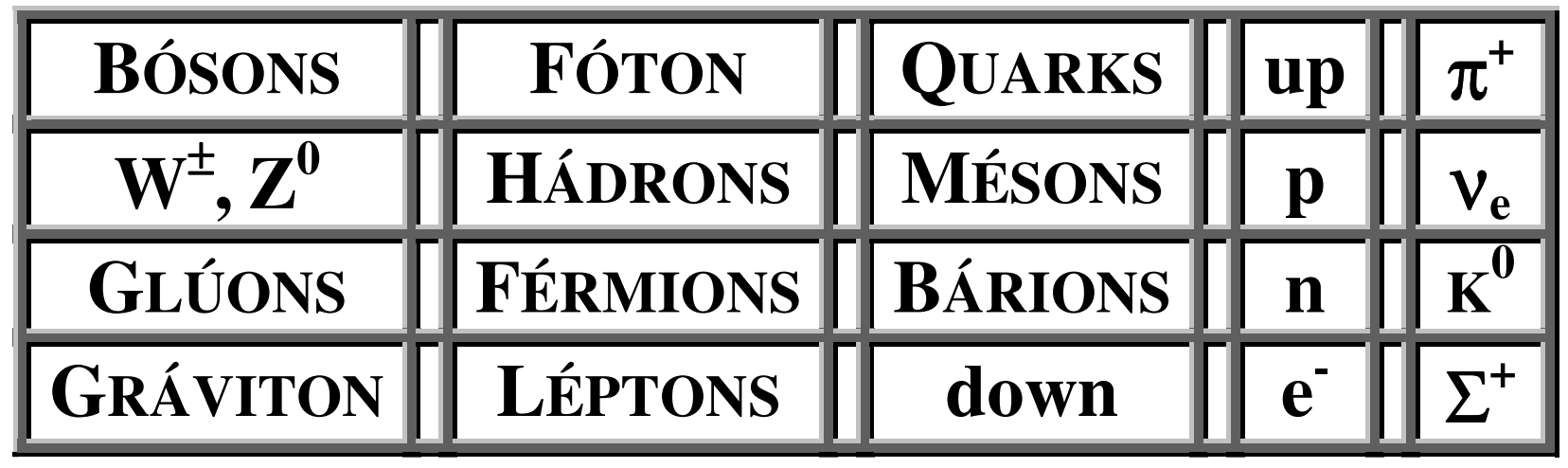




\section{PARTÍCULAS ELEMENTARES E INTERAÇÕES FUndAMENTAIS}

\section{Férmions \\ Spin $\hbar / 2$}

Obedecem ao princípio da exclusão de Pauli.

\section{Quarks}
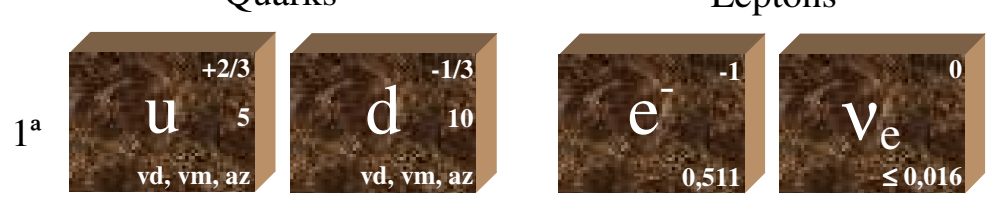

$2^{\mathrm{a}}$

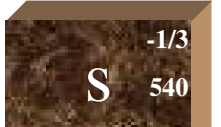

$\mathrm{vd}, \mathrm{vm}, \mathrm{az}$
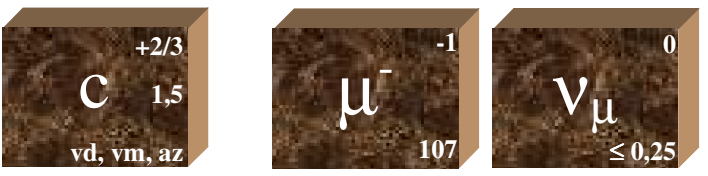

$3^{\mathrm{a}}$
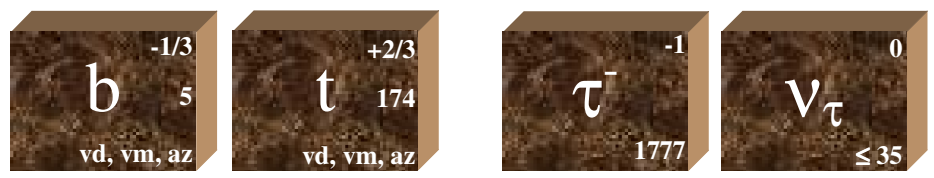

\section{Bósons}

Spin $\hbar$

Não obedecem ao princípio da exclusão de Pauli.
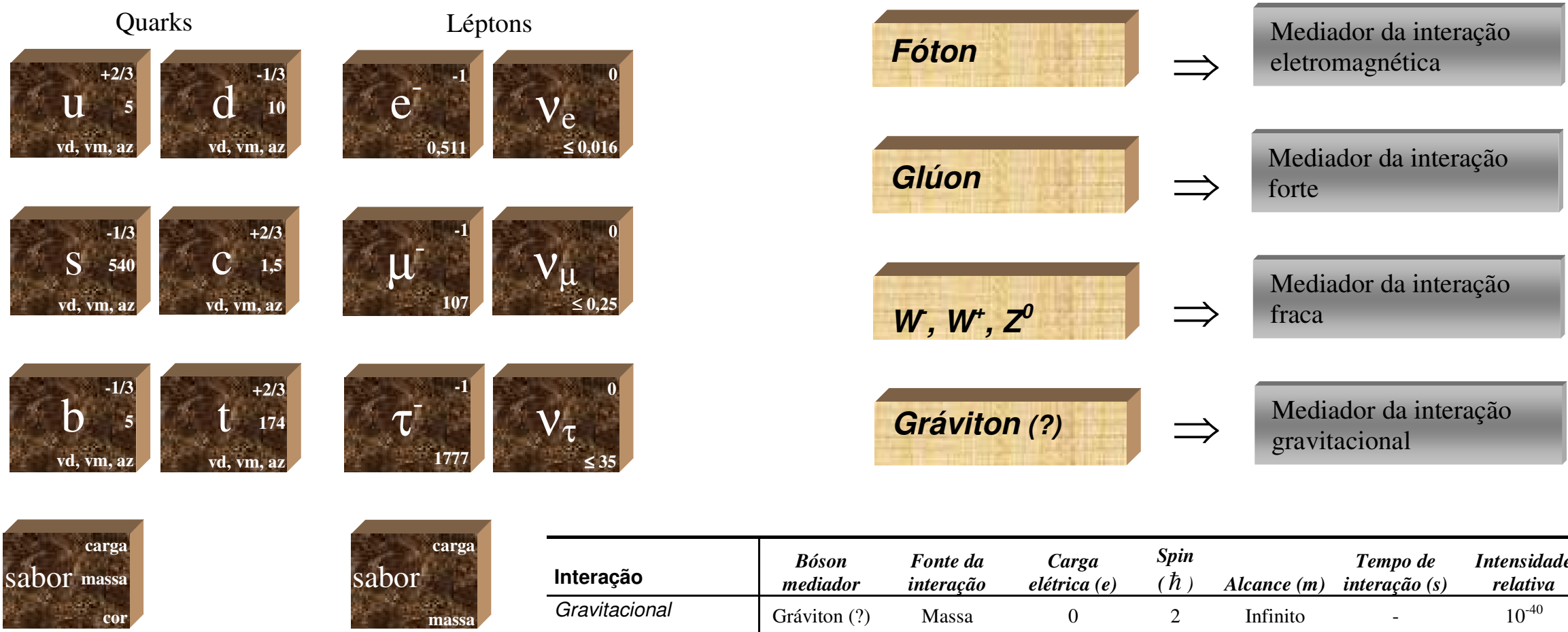

*Obs.: A massa das partículas é dada em $\mathrm{MeV} / \mathrm{c}^{2}$, exceto dos quarks charm, bottom e top, que é dada em Gev/c $\mathrm{c}^{2}$.

\begin{tabular}{|c|c|c|c|c|c|c|c|c|}
\hline \multicolumn{2}{|c|}{ Interação } & $\begin{array}{c}\text { Bóson } \\
\text { mediador }\end{array}$ & $\begin{array}{l}\text { Fonte da } \\
\text { interaçãa }\end{array}$ & $\begin{array}{c}\text { Carga } \\
\text { elétrica }(e)\end{array}$ & $\begin{array}{l}\text { Spin } \\
(\hbar)\end{array}$ & Alcance (m) & $\begin{array}{c}\text { Tempo de } \\
\text { interação }(s)\end{array}$ & $\begin{array}{c}\text { Intensidade } \\
\text { relativa }\end{array}$ \\
\hline \multicolumn{2}{|c|}{ Gravitacional } & Gráviton (?) & Massa & 0 & 2 & Infinito & - & $10^{-40}$ \\
\hline \multicolumn{2}{|c|}{ Eletromagnética } & Fóton & $\begin{array}{l}\text { Carga } \\
\text { elétrica }\end{array}$ & 0 & 1 & Infinito & $10^{-18}$ & $10^{-2}$ \\
\hline \multirow{2}{*}{ Forte } & Fundamental & Glúons & Carga cor & 0 & 1 & $10^{-15}$ & $10^{-23}$ & 1 \\
\hline & Residual & Mésons & Carga cor & 0 & 1 & $10^{-15}$ & $10^{-23}$ & 1 \\
\hline \multirow{2}{*}{\multicolumn{2}{|c|}{ Fraca }} & $\mathrm{W}^{-}, \mathrm{W}^{+}$ & Carga fraca & $-1,+1$ & 1,1 & $10^{-18}$ & $10^{-16}$ & $10^{-12}$ \\
\hline & & $Z^{0}$ & Carga fraca & 0 & 1 & $10^{-18}$ & $10^{-10}$ & $10^{-12}$ \\
\hline
\end{tabular}




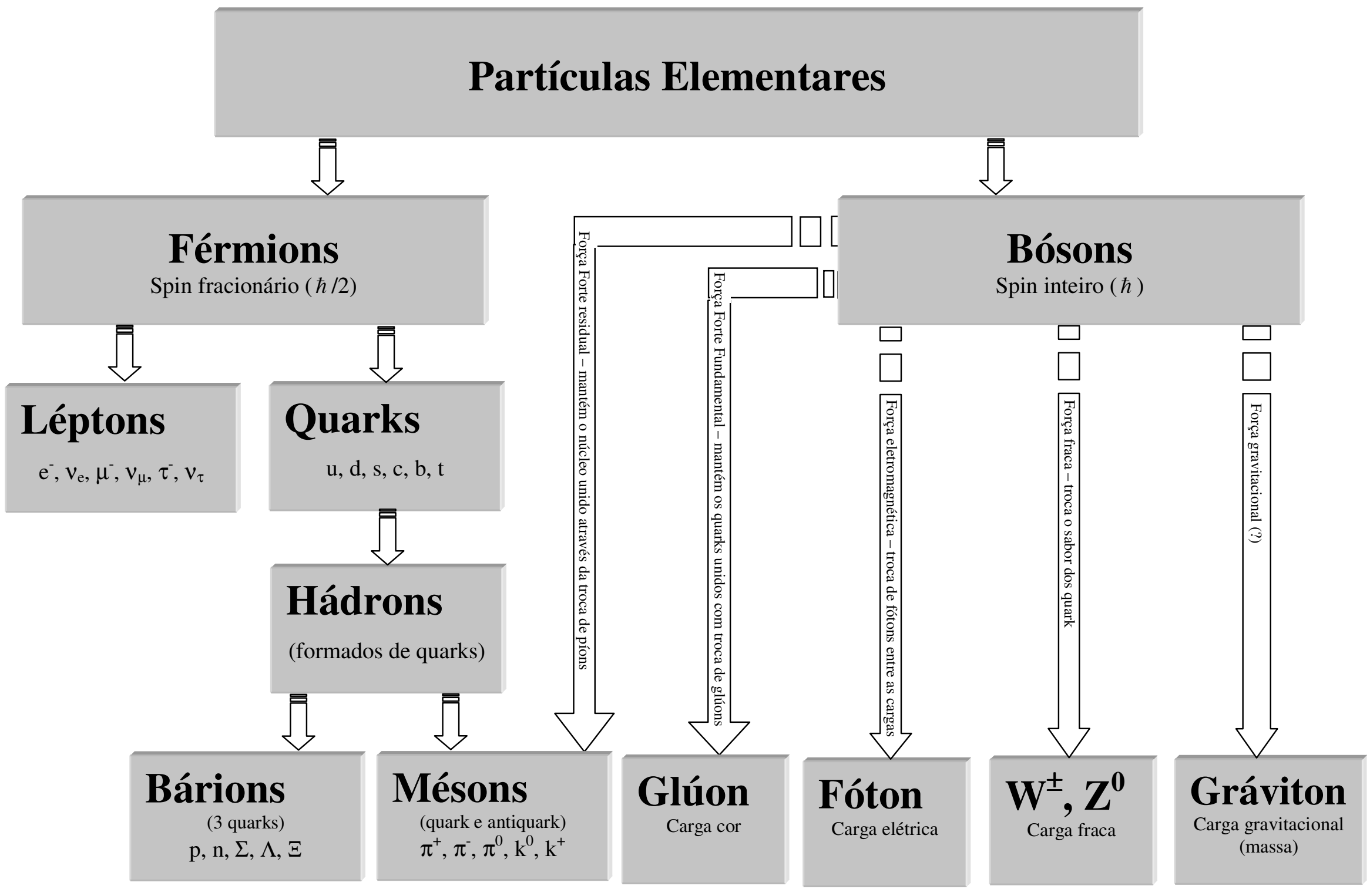




\section{Questões de Pesquisa: Instruções}

Pedimos que leia e responda, da maneira mais sincera possível, cada questão na ordem apresentada, não leia antecipadamente as questões posteriores;

Agradecemos profundamente sua valiosa colaboração, Wellington e Maxwell.

Questão 1: Avalie a compreensão dos textos utilizados no curso de Partículas:

( ) foram muito fáceis de compreender;

( ) foram complicados;

( ) foram fáceis de compreender;

( ) foram muito complicados.

Questão 2: Para compreender a matéria, os textos:

( ) ajudaram muito a pensar e compreender o assunto;

( ) ajudaram a pensar e compreender o assunto;

( ) pouco ajudaram a pensar e compreender o assunto;

( ) não ajudaram a pensar e compreender o assunto.

Questão 3: Avalie as questões e exercícios propostos no curso de física:

a) quanto à compreensão das questões e exercícios:

( ) foram muito fáceis de entender;

( ) foram fáceis de entender;

( ) foram difíceis de entender;

( ) foram muito difíceis de entender.

b) quanto à dificuldade na realização das questões e exercícios:

( ) foram muito fáceis de responder; _ ( ) foram difíceis de responder;

( ) foram fáceis de responder; $\quad$ ( ) foram muito difíceis de responder.

c) quanto à quantidade de questões e exercícios:

( ) foram muitas;

( ) foram suficientes;

( ) foram poucas;

( ) foram insuficientes.

Questão 4: Para responder às questões e exercícios as discussões na sala de aula:

( ) ajudaram muito;

( ) pouco ajudaram;

( ) ajudaram;

( ) não ajudaram.

Questão 5: Para responder às questões e exercícios:

( ) os textos ajudaram muito;

( ) os textos ajudaram pouco;

( ) os textos ajudaram;

( ) os textos não ajudaram em nada. 
Questão 6: Avalie a dificuldade do conteúdo apresentado:
( ) foi um conteúdo muito fácil;
( ) foi um conteúdo difícil;
( ) foi um conteúdo fácil;
( ) foi um conteúdo muito difícil.

Questão 7: Qual foi a atividade que você mais gostou de fazer:

( ) atividade do "Raios X e radiografias" ( ) atividade "a estrutura das partículas"

( ) atividade do "espalhamento"

( ) atividade "enxergando o invisível"

Por quê?

Questão 8: Qual destas atividades você menos gostou de fazer:

( ) atividade do "Raios X e radiografias" ( ) atividade "a estrutura das partículas"

( ) atividade do "espalhamento"

( ) atividade "enxergando o invisível"

Por quê?

Questão 9: Sobre a forma como as aulas e conteúdos estavam ligados, você as considerou:

( ) muito ligadas umas às outras; $\quad$ ( ) pouco ligadas umas às outras;

( ) ligadas umas às outras; não estavam ligadas umas às outras.

Questão 10: O que você achou do tema estudado:
( ) muito interessante;
( ) pouco interessante; 
( ) interessante; $\quad$ ( ) nada interessante.

Questão 11: Como você se sentiu durante o curso:

( ) nada perdido

( ) um pouco perdido

( ) perdido

( ) muito perdido

diga o que levou a sentir-se assim:

Questão 12: Sobre a atividade "Raios X e radiografias" você percebeu qual era o objetivo desta atividade?
( ) $\operatorname{sim}$
( ) não

Se percebeu, diga qual era. Caso não tenha percebido explique por que acha que não foi possível perceber.

Questão 13: Sobre a atividade "espalhamento" você percebeu qual era o objetivo desta atividade?
( ) $\operatorname{sim}$
( ) não

Se percebeu, diga qual era. Caso não tenha percebido explique por que acha que não foi possível perceber. 
Questão 14: Sobre a atividade "enxergando o invisível", você percebeu qual era o objetivo desta atividade?
$($ ) $\operatorname{sim}$
( ) não

Se percebeu, diga qual era. Caso não tenha percebido explique por que acha que não foi possível perceber.

Questão 15: Sobre a atividade "a estrutura das partículas" você percebeu qual era o objetivo desta atividade?
( ) $\operatorname{sim}$
( ) não

Se percebeu, diga qual era. Caso não tenha percebido explique por que acha que não foi possível perceber.

Questão 16: Durante as aulas você deve ter percebido que a concepção de átomo foi mudando com o passar do tempo.

a) Porque você acha que estas mudanças aconteceram?

b) Você acha que estas mudanças irão para de acontecer? 
c) Esta mudança na concepção do átomo fez com que você mudasse sua maneira de olhar o mundo a sua volta

\begin{tabular}{|l|l}
\hline ( ) $\operatorname{sim}$ & ( ) não \\
\hline
\end{tabular}

Por que?

\section{Questão 17:}

a) Quando começaram as aulas, em agosto, o que você pensava que era a Física?

b) Sua idéia continua a mesma ou mudou?

\begin{tabular}{|l|l}
\hline ( ) $\operatorname{sim}$ & ( ) não \\
\hline
\end{tabular}

Se mudou, o que mudou? Por que acha que mudou?

\section{Questão 18:}

Destaque um aspecto que diferenciou este curso do curso de Física que você teve nos anos anteriores. Comente. 
Utilize este espaço para escrever o que quiser a respeito do curso e que não tenha sido abordado neste questionário.

Obrigado!

Maxwell e Wellington 